\title{
Administrative Proceedings in the Habsburg Succession Countries
}


紫 


\section{COMPARATIVE LEGAL STUDIES}

edited by Zbigniew Kmieciak

\section{Administrative Proceedings in the Habsburg} Succession Countries 
Zbigniew Kmieciak - University of Łódź, Faculty of Law and Administration Institute of Comparative and Interdisciplinary Research in Law

90-232 Łódź, 8/12 Kopcińskiego St.

\author{
REVIEWER \\ Jerzy Supernat \\ INITIATING EDITOR \\ Monika Borowczyk \\ TYPESETTING \\ AGENT PR \\ TECHNICAL EDITOR \\ Anna Sońta
}

COVER DESIGN

Agencja Reklamowa efectoro.pl

Cover Image: https://commons.wikimedia.org/wiki/File:Austria-Hungary1899.JPG

(c) Copyright by Authors, Łódź 2021

(c) Copyright for this edition by Uniwersytet Łódzki, Łódź 2021

(c) Copyright for this edition by Wolters Kluwer Polska sp. z o.o., Warszawa 2021

Published by Łódź University Press

Published by Wolters Kluwer Polska sp. z o.o.

First edition. W.09504.19.0.K

Publisher's sheets 20.9; printing sheets 19.5

ISBN 978-83-8220-065-2 (WUŁ)

e-ISBN 978-83-8220-066-9 (WUŁ)

ISBN 978-83-8187-516-5 (WKP)

Łódź University Press

90-131 Łódź, 8 Lindleya St.

www.wydawnictwo.uni.lodz.pl

e-mail: ksiegarnia@uni.lodz.pl

phone. 426655863

Wolters Kluwer Polska sp. z o.o.

01-208 Warszawa, ul. Przyokopowa 33

e-mail:ksiazki@wolterskluwer.pl

księgarnia internetowa www.profinfo.pl 


\section{Table of Contents}

Foreword (Jean-Bernard Auby, emeritus public law professor of Sciences Po, Paris)

Słowo wstępne (Jean-Bernard Auby, emerytowany profesor prawa publicznego, Instytut Nauk Politycznych w Paryżu)

Introduction (Zbigniew Kmieciak, University of Łódź)

Wprowadzenie (Zbigniew Kmieciak, Uniwersytet Łódzki)

Chapter I. In the Circle of the Austrian Codification Ideas (Zbigniew Kmieciak, University of Łódź)

Rozdziat I. W kręgu austriackich idei kodyfikacyjnych (Zbigniew Kmieciak, Uniwersytet Łódzki)

Chapter II. Administrative Procedure in Austria - from the Monarchy to the Republic (Laura Rathmanner, University of Vienna)

Chapter III. Austria (Peter Chvosta, the Austrian Federal Administrative Court in Vienna)

Chapter IV. Croatia (Dario Đerđa, University of Rijeka)

Chapter V. Czech Republic (Kateřina Frumarová, Palacky University in Olomouc)

Chapter VI. Hungary (András Patyi, the Curia - Budapest)

Chapter VII. Italian Concept of Law on Administrative Proceedings. Opera aperta? (Maciej Wojtuń, University of Łódź)

Chapter VIII. Poland (Joanna Wegner, University of Łódź)

Chapter IX. Serbia (Dejan Vučetić, University of Niš)

Chapter X. Slovak Republic (Juraj Vačok, Comenius University in Bratislava)

Chapter XI. Slovenia (Bruna Žuber, University of Ljubljana) 
Chapter XII. The Legacy of the Austrian Codification Thought - an European Perspective (Agnieszka Krawczyk, University of Łódź)

Rozdział XII. Dziedzictwo austriackiej myśli kodyfikacyjnej z perspektywy europejskiej (Agnieszka Krawczyk, Uniwersytet Łódzki)

Chapter XIII. ReNEUAL's Model Rules in the Light of the "Common Core" of European Administrative Law (Giacinto della Cananea, Bocconi University, Milan)

Rozdział XIII. Reguły modelowe ReNEUAL w świetle wspólnych zasad europejskiego prawa administracyjnego (Giacinto della Cananea, Uniwersytet Bocconi, Mediolan) 


\section{Foreword}

It is a pleasure and an honour to preface the very interesting book you are about to read. The subject of this book is original and quite relevant. It is to study the trace left by the great Austrian 1925 Administrative Procedure Act in Austrian law itself and in the countries which were directly exposed to its influence: Croatia, Czech Republic, Hungary, Italy, Poland, Serbia, Slovakia and Slovenia.

The Austrian 1925 Act can be considered as the first real code of administrative procedure in history, even if one should not forget the precedent of the Spanish "Azcarate" law of 1889: but this text, which consisted of only five articles, regulated only a minimum of questions and for the rest referred to ministerial regulations, was not yet truly a general law of administrative procedure.

The Austrian 1925 Act constitutes a great historical model, to which can only be compared the US Administrative Procedure Act of 1946 and the German general law on administrative procedure - Verwaltungsverfahrensgesetz - of 1976. What were the main characteristics of this Austrian model, whose essential features strongly contributed to a Germanic tradition to which German law is also attached?

First of all, the law of 1925 was indeed a law of codification: while largely inspired by the jurisprudence of the Administrative Court created in 1875, it laid down general rules which would apply wherever specific rules were not provided for by particular pieces of legislation.

It was largely based on the concept of party and a subjective approach to the administrative procedure, deemed to consist in settling individual problems posed to the administration in line with the rights of individuals. The book shows that this characteristic can be found in all the general procedural laws studied.

The 1925 Act was also centered on the notion of administrative act and even on the one of administrative decision. According to it, the normal outcome of an administrative procedure was to produce a formal administrative decision, which would settle the problem submitted to the administration. This remains true in legislations influenced by the Austrian model, even if, as explained in the book, some of them - the Hungarian and Croatian ones - now take a more flexible view and accept that an administrative procedure should lead to an informal decision or even a contract. 
A very important point is the fact that the administrative act on which the Austrian law focused, like all other legislation studied, was an individual administrative decision. This is another constant orientation of the Germanic tradition, in which the regulatory acts issued by the administration do not have the nature of administrative acts: they are rather similar to legislative acts. This position is in contrast to the one adopted by other legal traditions, in which administrative regulations are a variety of administrative acts and are therefore included in the scope of application of codes of administrative procedure, even if it is to be there subject to rules partially different from those that apply to individual decisions: this is what can be found in French law, for example. It should also be noted that, although it is not centered on the notion of administrative act, the US APA is in the same vein, since it governs both the procedures for resolving particular problems - "adjudication" - and the procedures for issuing general administrative standards - "rulemaking".

Another feature of the Austrian tradition embodied in the law of 1925 was the existence of administrative appeals on the merits, which were an obligatory first step in case of litigation. It is true that, strikingly enough, Austrian law itself departed from this tradition by abolishing these administrative appeals, except in municipal cases: but the other general administrative procedure laws keep it up.

The book shows that the 1925 Act has had a profound and lasting influence on procedural administrative law in the various examined jurisdictions. Austrian Law remained largely faithful to its principles. In its aftermath, several similar pieces of legislation were adopted: in Czechoslovakia and Poland - in 1928, in Yugoslavia - thus impacting Croatia, Serbia and Slovenia - in 1930. Particularly striking is the fact that, in the countries which went through socialist regimes, administrative procedure did not deviate much from the inherited tradition, even where judicial review, on its part, suffered sometimes drastic weakening: the book mentions this in the cases of Hungary and Poland.

All this does not mean that the 1925 Act heritage remained untouched. The book, for example, shows how difficult it has been, in all considered countries, to resist to decodification trends. In all cases, apparently, the general administrative procedure act has had a subsidiary status and has been made applicable "unless special provisions specify otherwise". Then, even where it has been ruled that deviating from the general act was only admitted when indispensable - as it was by the Austrian Constitutional Court - it proved difficult to resist the tendency to insert specific procedural rules in special substantive legislations, especially in certain fields like the tax one.

Moreover, the procedural administrative laws the book covers have been influenced by contemporary evolutions in the common European vision of good governance, good administration and the strengthening of the rights of the citizens in their relationship with the administration, which express themselves in the Council of Europe's work, especially the European Convention on Human Rights and in the EU Charter of Fundamental Rights. Very significant in this respect is 
the fact that several of the most recent of them include the affirmation of a bundle of principles - the Croatian one, the Czech one, the Italian one, the Serbian one, the Slovenian one - in a way which evoke the modern human rights declaration.

Anyway, situated in a period where Austrian administrative law was in full development, the Austrian model of administrative procedural legislation remains a strong historical reference, still influential, and we must be grateful to Zbigniew Kmieciak and the other authors for so well demonstrating why and to what extent.

Bayonne, April 12, 2020

Jean-Bernard Auby emeritus public law professor of Sciences Po, Paris jeanbernard.auby@sciencespo.fr 



\section{Słowo wstępne}

Opatrzenie przedmową niniejszej, bardzo interesującej książki jest dla mnie przyjemnością i zaszczytem. Jej tematyka jest bez wątpienia nowatorska i doniosła. Omówiono w niej wkład wniesiony przez wielką austriacką ustawę o postępowaniu administracyjnym z 1925 r. w rozwój prawa w samej Austrii oraz w państwach będących bezpośrednio pod jego wpływem: Chorwacji, Czechach, Węgrzech, Włoszech, Polsce, Serbii, Słowacji i Słowenii.

Austriacką ustawę z 1925 r. należy uznać za pierwszy w historii kompletny kodeks postępowania administracyjnego, nawet jeśli uwzględnimy precedensową ustawę hiszpańską Azcarate z 1889 r. Drugi z tych aktów liczył tylko pięć artykułów, regulował nieliczne kwestie, odsyłając - co do reszty - do rozporządzeń ministerialnych. Nie był on więc ustawą o ogólnym postępowaniu administracyjnym w pełnym tego słowa znaczeniu.

Austriacka ustawa z $1925 \mathrm{r}$. stanowi wielki historyczny model, z którym mogą się równać jedynie amerykańska ustawa o postępowaniu administracyjnym z $1946 \mathrm{r}$. oraz niemieckie Ogólne prawo o postępowaniu administracyjnym (Verwaltungsverfahrensgesetz) z 1976 r. Jakie były główne atrybuty wspomnianego modelu, którego zasadnicze cechy silnie zakorzeniły się w tradycji germańskiej i przeniknęły także do ustawy niemieckiej?

Ustawa z 1925 r., choć w dużym stopniu inspirowana orzecznictwem utworzonego w 1875 r. Trybunału Administracyjnego, była aktem rzeczywistej kodyfikacji. Zawierała ogólne zasady, które miały zastosowanie wszędzie tam, gdzie przepisy szczególne nie stanowiły inaczej. Jej podstawowe założenia określono, formułując koncepcję strony i subiektywnego ujęcia postępowania administracyjnego jako trybu rozstrzygania indywidualnych spraw administracyjnych zgodnie z przysługującymi jednostkom prawami. Książka wskazuje, że ta charakterystyka odnosi się do wszystkich ustaw proceduralnych stanowiących przedmiot ogólnych analiz.

Ustawa z 1925 r. posługiwała się również pojęciem aktu administracyjnego i decyzji administracyjnej jako odmiany tego aktu. Stosownie do niej standardowym sposobem zakończenia postępowania administracyjnego było wydanie formalnej decyzji administracyjnej rozstrzygającej problem, z którym zetknęła się administracja. Zasada ta jest aktualna $\mathrm{w}$ ustawodawstwach czerpiących $\mathrm{z}$ tradycji austriackiej, nawet jeśli - jak wyjaśniono - w niektórych z nich, np. w węgierskim i chorwackim, 
przyjęto bardziej elastyczne stanowisko w tej materii, akceptując możliwość zakończenia postępowania administracyjnego niewyrażoną wprost decyzją albo umową.

Podkreślenia wymaga, że zarówno w austriackiej ustawie, jak i w pozostałych omówionych w książce akt administracyjny przybiera postać indywidualnej decyzji administracyjnej. To kolejny stały przymiot germańskiej tradycji prawnej, wedle której akty regulacyjne wydawane przez organy administracji nie mają charakteru aktów administracyjnych: zdecydowanie bliżej im do aktów prawodawczych. Inaczej wygląda to w systemach prawnych, w których przepisy administracyjne uznawane są za kategorię aktów administracyjnych. Ich wydawanie objęte jest tam reżimem wyznaczonym przez kodeksy postępowania administracyjnego, nawet gdy aktywność ta podlega częściowo innym zasadom niż te, które odnoszą się do indywidualnych decyzji (tak właśnie jest w prawie francuskim). Podobnie amerykańska ustawa o postępowaniu administracyjnym, chociaż nie koncentruje się na pojęciu aktu administracyjnego, normuje zarówno procedurę rozwiązywania kwestii jednostkowych - „orzekanie”, jak i procedurę kształtowania ogólnych standardów administracyjnych - „regulowanie”.

Inną konstrukcją wprowadzoną przez ustawę z 1925 r. jest odwołanie administracyjne co do meritum sprawy, którego wniesienie stanowi obowiązkowy, pierwszy krok w przypadku chęci zabiegania o ochronę na drodze sądowej. Co zastanawiające, prawo austriackie samo odstąpiło od tej zasady, znosząc tę instytucję we wszystkich sprawach poza gminnymi. Została ona natomiast zachowana $\mathrm{w}$ innych ogólnych ustawach o postępowaniu administracyjnym.

W zbiorze ukazano, jak głęboki i trwały wpływ na prawo o postępowaniu administracyjnym różnych rozpatrywanych systemów wywarła ustawa z 1925 r. Prawo austriackie pozostało w dużej mierze wierne jej zasadom. Ustawę, o której mowa, można śmiało traktować jako pierwowzór dla kilku innych aktów legislatywy, przyjętych w Czechosłowacji i w Polsce (1928) oraz w Jugosławii (1930), a w konsekwencji - w Chorwacji, Serbii i Słowenii. Szczególnie interesujący jest fakt, że w państwach bloku socjalistycznego procedura administracyjna nie odbiegła zbytnio od wzorów austriackich, choć kontrola sądowa doznała w nich drastycznego osłabienia - w książce podano przykład Węgier i Polski.

Wszystko to nie oznacza, że dziedzictwo aktu z 1925 r. pozostało niezmienione. W niniejszym zbiorze wskazano m.in., jak trudno jest współcześnie oprzeć się trendowi dekodyfikacji. Oczywiście ustawa o ogólnym postępowaniu administracyjnym w każdym przypadku ma charakter subsydiarny i znajduje zastosowanie, „o ile przepisy szczególne nie stanowią inaczej”. Jednak i w takiej sytuacji odstępstwa od jej zasad są - jak orzekł austriacki Trybunał Konstytucyjny - dopuszczalne tylko, gdy jest to niezbędne, choć uniknięcie pokusy wprowadzania szczególnych przepisów proceduralnych $\mathrm{w}$ ramach regulacji prawa materialnego, zwłaszcza w pewnych dziedzinach (np. w sferze podatków), nie jest łatwe.

Wypada jeszcze dodać, że na kształt ustaw o postępowaniu administracyjnym będących przedmiotem opracowania wpłynęły współczesne zmiany we wspólnej 
europejskiej wizji dobrego zarządzenia, dobrej administracji i wzmacniania praw obywateli w relacjach $\mathrm{z}$ administracją, których odzwierciedleniem są rezultaty prac Rady Europy, zwłaszcza postanowienia Europejskiej konwencji o ochronie praw człowieka i podstawowych wolności, a z drugiej strony - standardy zdefiniowane w Karcie praw podstawowych Unii Europejskiej. Niezwykle istotne jest to, że kilka nowszych ustaw, a mianowicie chorwacka, czeska, włoska, serbska czy słoweńska, odwołuje się do pakietu tak rozumianych zasad w sposób właściwy dla nowoczesnych deklaracji praw człowieka.

Tak czy inaczej, model regulacji postępowania administracyjnego stworzony w okresie, w którym austriackie prawo administracyjne znajdowało się w pełni rozkwitu, pozostaje mocnym odniesieniem historycznym, nadal znaczącym. Musimy być zatem wdzięczni Zbigniewowi Kmieciakowi i innym autorom książki za tak dobre wyjaśnienie, dlaczego oraz w jakim zakresie nim operujemy.

Bajonna, 12 kwietnia $2020 \mathrm{r}$.

Jean-Bernard Auby emerytowany profesor prawa publicznego Instytut Nauk Politycznych w Paryżu jean-bernard.auby@sciencespo.fr (tłum. Monika Kmieciak) 



\section{Introduction}

The concept of writing the book was born spontaneously in the summer of 2019. It arose under the influence of a question from one of our foreign colleagues about the possibility of preparing the next edition of the collective work: Administrative Proceedings in Europe. ${ }^{1}$ This motivated my friends - the employees of the University of Lodz (Department of Administrative Procedure) to create another, unique study. As a scientific editor, I have the honour of introducing the research concept in its final shape.

The book shows the evolvement and present condition of administrative procedure law in nine European countries. The authors' intention was to identify the differences and similarities in administrative procedures, the origins of which should be found in the solutions developed in times of the Habsburg Monarchy, primarily in the course of judicial activity of the Vienna Administrative Court (Verwaltungsgerichtshof). The procedural assumptions (standards) made by this Court between 1890 and $1910^{2}$ are considered to be the most significant. They became the foundation for Austrian codification of general administrative procedure which was implemented by the Act of 1925 - Allgemeines Verwaltungsverfahrensgesetz. ${ }^{3}$ The constructions of procedural law created at that time were adopted by most Habsburg succession countries. ${ }^{4}$ Political, social and institutional changes that took place in these states after the Second World War and at the turn of the 20th and 21st centuries significantly modified the Austrian concept of codification, which some theorists assumed as a "model". Development directions of

1 Administrative Proceedings in Europe, ed. Z. Kmieciak, Warsaw 2005 and 2010.

2 See A. Ferrari Zumbini, Judicial Review of Administrative Action in Austro-Hungarian Empire. The Formative Years (1890-1910), "Italian Journal of Public Law" 2018, vol. 10, issue 1, pp. 9-48.

3 Bundesgesetzblatt no. 274/1925.

4 According to some literature opinions: "Undoubtedly, borrowing is facilitated in turn by administrative procedure taking codified form, for codes transplant more easily than the decisional law of courts. The proliferation of codes in the former communist countries of central and eastern Europe offers the most dramatic evidence" - in this way: G.A. Bermann, Foreword, [in:] Codification of Administrative Procedure, ed. J.-B. Auby, Bruxelles 2014, p. Vl, see also G. della Cananea, Due Process of Law Beyond the State. Requirements of Administrative Procedure, Oxford 2016, p. 26. 
administrative procedure in this part of Europe began to undergo the process of gradual differentiation among themselves. However, the main assumptions of the Austrian codification of administrative proceedings that were almost a hundred years ago have been preserved, and even, not surprisingly, the essence and content of many procedural rules.

Italy, whose northern regions were once part of the Habsburg Empire, pursues its own original vision for the development of administrative procedural law. The book answers the question why Austrian solutions were not used there in favor of the "pragmatic", though incomplete codification of administrative procedure. It was done relatively late because in 1990. Even later, work on the codification of administrative procedure was undertaken in another country, whose territories were partly within the borders of the Empire, namely Romania. The project of Act - Codul de procedură administrativă, was only composed there in the second decade of the 21 st century.

It is obvious that a comparison of legislation of the Habsburg succession countries in terms of administrative procedure poses numerous questions. It would be particularly interesting to find out why some legal systems are more open to innovations and reforms while others avoid deeper and radical changes. Does the permanent modernisation of law stay in conflict with the idea of codifying administrative procedure? Do the old codification objectives still match the challenges of modern legislation? Is there only one model of administrative procedure, or rather several of its varieties in the Habsburg succession countries of the Post-Socialist Bloc? What is the role of science in outlining the vision of the legislation, designing amendments thereto and evaluating the functioning of current regulations? Is exaggerated adhering to the tradition and established framework for action of public administration not a factor that hinders the progress? A separate issue is the role of case law in creating principles of administrative procedure, and thus "supplementing" activities of the legislature.

The research questionnaire handed to the individual authors has become a tool for capturing some rules governing the development of law on administrative procedure in Austria itself, as well as in other Habsburg succession countries. The reflections contained in Chapters III - VI and VIII - IX are centered around its eleven points. The analyses included in this part of the book correspond to the following scheme:

1. The stages of evolution of the law on administrative procedure - from the first codification.

2. The scope of the code regulation on administrative proceedings, including the aspect of subsidiary application of the provisions on general administrative procedure.

3. The characteristic institutions and peculiarities of the law on administrative procedure.

4. Relation between the legal institutions of administrative procedure and the model of judicial review of administration. 
5. Influence of the Austrian codification idea on the shape of modern legal solutions (it does not apply to Chapter III; instead, there is an overview of the objectives and effects of the constitutional reform from 2012).

6. Impact of the European law on the national legislature and judicature.

7. Openness to innovation - is the strive for modernization visible in activities of the legislature?

8. Codification of administrative procedure and de-codification trends.

9. Codification of administrative procedure and practice.

10. Successes and failures - what has not been achieved?

11. General conclusions and comments on the prospects for the development of the law on administrative procedure.

Chapters I and II introduce to the national experts' studies. They describe the genesis of the Austrian codification and evolution of its ideas in the Habsburg succession countries. The last two chapters are intended to answer questions about the contemporary dimension of the Austrian codification thought, and the outcome of the evolution of solutions that are a common heritage of European legal systems, including the challenges of codification at EU level. The authors' conclusions can be briefly described in the form of a statement: solutions created a century ago still exist in the legislation and practice of the Habsburg succession countries and in Austria itself. However, they have been modified and supplemented with new constructions. Adapting, almost in pure form, the Austrian model was an interesting legislative experiment. This move confirms the belief that in the course of lawmaking we have to take into account the experiences of others: their mistakes and successes. In certain historical conditions, the borrowing method seems to be the simplest and most effective way to achieve the set goals. In the case of countries that regained independence after the First World War (Czechoslovakia, Yugoslavia and Poland), there was no sensible alternative. What is equally important, are the results of the choice made survived the era of socialism. It also gives reflection that the phenomenon of gradual differentiation of administrative procedure law evolution in this part of Europe has a limited range and does not endanger the legal tradition of this region.

The publishing of the book coincided with the 60th anniversary of the Polish Code of Administrative Procedure. It is the oldest of the codes currently in force in Poland. At the same time, it is one of the earliest administrative procedure codes in Europe. The considerations presented in the book are in a way of a tribute to the authors of this act and its counterparts in other Habsburg succession countries.

Mindful of the effort put into the preparation of this collection, I would like to express most sincere thanks to all excellent colleagues of mine, the authors of its individual parts. The editorial works on the book were conducted during the extremely difficult and unexpected times of the corona-virus pandemic. This dramatic event has allowed people to understand how fragile the existence of humanity is, but still the situation has not deprived us from the sense of the freedom 
of thought and value of comparative research in the field of law. Paradoxically, the fight against pandemic revealed the hidden or less known earlier face of the administrative proceedings - usefulness of urgent and simplified modes, advantages of reducing the degree of procedural formalism and respecting the principle of pragmatism in the course of official activities. Appreciating the contribution of so many people involved in the creation of the publication, I must stress that as a scientific editor of the work I take full and sole responsibility for the result of this mutual undertaking. 


\section{Wprowadzenie}

Pomysł napisania tej książki powstał spontanicznie latem 2019 r. W związku z pytaniem jednego z zagranicznych kolegów, dotyczącym możliwości przygotowania kolejnej edycji pracy zbiorowej: Postępowanie administracyjne $w$ Europie ${ }^{1}$, w gronie pracowników Katedry Postępowania Administracyjnego na Wydziale Prawa i Administracji Uniwersytetu Łódzkiego zrodziła się idea stworzenia innego, oryginalnego, choć o podobnej tematyce dzieła. Mnie, jako jego redaktorowi naukowemu, przypadł w udziale zaszczyt nadania temu pomysłowi ostatecznego kształtu.

W książce przedstawiono rozwój i stan obecny prawa o postępowaniu administracyjnym w dziewięciu państwach europejskich. Intencją autorów było ukazanie różnic i podobieństw procedur administracyjnych, których genezy należy upatrywać w rozwiązaniach ukształtowanych w czasach Monarchii Habsburskiej, przede wszystkim w toku działalności orzeczniczej wiedeńskiego Trybunału Administracyjnego (Verwaltungsgerichtshof). Za najbardziej znaczące uznaje się założenia (standardy) proceduralne określone przez ten Trybunał w latach $1890-1910^{2}$. Stały się one fundamentem austriackiej kodyfikacji ogólnego postępowania administracyjnego dokonanej ustawą z 1925 r. - Allgemeines Verwaltungsverfahrensgesetz $z^{3}$. Stworzone wówczas konstrukcje prawa procesowego zostały przejęte przez ustawodawstwo większości państw sukcesji habsburskiej. Zmiany polityczne, społeczne i ustrojowe,

1 Postępowanie administracyjne w Europie, red. Z. Kmieciak, Warszawa 2005 i 2010.

2 Zob. A. Ferrari Zumbini, Judicial Review of Administrative Action in Austro-Hungarian Empire. The Formative Years (1890-1910), „Italian Journal of Public Law” 2018, vol. 10, issue 1, s. 9-48. Bundesgesetzblatt Nr 274/1925.

4 W literaturze naukowej prezentowana jest opinia, że stosowanie techniki zapożyczeń jest łatwiejszym sposobem kodyfikowania postępowania administracyjnego niż nadawanie formy przepisów rangi ustawowej ustaleniom prawa sędziowskiego. Przyjmuje się, że jaskrawym dowodem zasadności tego spostrzeżenia jest rozwój uregulowań kodeksowych w byłych państwach komunistycznych centralnej i wschodniej Europy (borrowing is facilitated in turn by administrative procedure taking codified form, for codes transplant more easily than the decisional law of courts. The proliferation of codes in the former communist countries of central and eastern Europe offers the most dramatic evidence) - tak G.A. Bermann, Foreword, [w:] Codification of Administrative Procedure, ed. J.-B. Auby, Bruxelles 2014, s. VI, podobnie - G. della Cananea, Due Process of Law Beyond the State. Requirements of Administrative Procedure, Oxford 2016, s. 26. 
które zaszły w tych państwach po drugiej wojnie światowej oraz na przełomie XX i XXI w., doprowadzily do nieuchronnej modyfikacji austriackiej koncepcji kodyfikacyjnej, ocenianej skądinąd przez niektórych teoretyków jako „wzorcowa”. Drogi rozwoju prawa o postępowaniu administracyjnym w tej części Europy rozeszły się w jakimś stopniu. Zachowane zostały jednak główne założenia dokonanych w Austrii prawie 100 lat temu zabiegów kodyfikacyjnych, a nawet - co nie jest bynajmniej czymś zaskakującym - rdzeń i treść wielu dawnych uregulowań procesowych.

Państwem, którego północne regiony wchodziły niegdyś w skład imperium habsburskiego, realizującym własną, oryginalną wizję rozwoju prawa o postępowaniu administracyjnym, są Włochy. W książce udzielono odpowiedzi na pytanie, dlaczego nie zdecydowano się tam na adaptację rozwiązań austriackich, opowiadając się za wariantem „pragmatycznej”, choć niepełnej kodyfikacji postępowania administracyjnego. Dokonano jej stosunkowo późno, gdyż w 1990 r. Jeszcze później prace nad kodyfikacją postępowania administracyjnego zainicjowano $\mathrm{w}$ innym państwie, którego część ziem również pozostawała w granicach imperium, to jest w Rumunii. Projekt ustawy - Codul de procedură administrativă - sporządzono tam dopiero w drugiej dekadzie XXI w.

Porównanie ze sobą ustawodawstwa państw sukcesji habsburskiej w przedmiocie postępowania administracyjnego skłania oczywiście do stawiania rozmaitych pytań. Interesujące byłoby zwłaszcza ustalenie, dlaczego jedne systemy prawne są bardziej otwarte na innowacje i reformy, inne zaś unikają głębszych i radykalnych zmian. Czy permanentna modernizacja prawa kłóci się z ideą kodyfikacji postępowania administracyjnego? Czy dawne zamierzenia kodyfikacyjne przystają jeszcze do wyzwań współczesnej legislacji? Czy możemy nadal mówić o istnieniu w państwach sukcesji habsburskiej bloku postsocjalistycznego jednego modelu postępowania administracyjnego, czy raczej kilku odmian takiego modelu? Jaka jest rola nauki w wytyczaniu wizji i projektowaniu zmian ustawodawstwa, a także przeprowadzaniu oceny funkcjonowania obowiązujących uregulowań? Czy przesadne przywiązanie do tradycji i utartego już schematu działań administracji publicznej nie jest czynnikiem, który ogranicza postęp? Odrębnym zagadnieniem jest rola case law w kreowaniu zasad postępowania administracyjnego i „uzupełniania” w ten sposób działań legislatywy.

Narzędziem pozwalającym na uchwycenie prawidłowości rządzących rozwojem prawa o postępowaniu administracyjnym zarówno w samej Austrii, jak i w innych państwach sukcesji habsburskiej stał się kwestionariusz badawczy, przekazany poszczególnym autorom. Wokół jego 11 punktów koncentrują się rozważania zawarte w rozdziałach III-VI i VIII-XI. Analizy zamieszczone w tej części książki odpowiadają następującemu schematowi:

1. Etapy ewolucji prawa o postępowaniu administracyjnym - poczynając od pierwszej kodyfikacji.

2. Zakres obowiązywania regulacji kodeksowej o postępowaniu administracyjnym, w tym problem subsydiarnego stosowania przepisów o ogólnym postępowaniu administracyjnym. 
3. Charakterystyczne instytucje i osobliwości prawa o postępowaniu administracyjnym.

4. Zależność między instytucjami prawa o postępowaniu administracyjnym a modelem sądowej kontroli administracji.

5. Wpływ austriackiej idei kodyfikacyjnej na kształt współczesnych rozwiązań prawnych (nie dotyczy rozdziału III; zamiast tych rozważań - charakterystyka celów i skutków reformy konstytucyjnej z 2012 r.).

6. Wpływ prawa europejskiego na działania krajowej legislatywy i judykatury.

7. Otwartość na innowacje - czy w poczynaniach legislatywy widoczne jest dążenie do modernizacji procedury?

8. Idea kodyfikacji postępowania administracyjnego a tendencje dekodyfikacyjne.

9. Kodyfikacja postępowania administracyjnego a praktyka.

10. Sukcesy i porażki - czego nie udało się zrealizować?

11. Perspektywy rozwoju prawa o postępowaniu administracyjnym.

Wprowadzeniem do analizy przedstawionej przez ekspertów krajowych są rozdziały I i II, w których ukazano genezę austriackiej kodyfikacji prawa o postępowaniu administracyjnym i rozwój kojarzonych z tą kodyfikacją idei w państwach sukcesji habsburskiej. W dwóch ostatnich rozdziałach podjęto próbę odpowiedzi na pytania o współczesny wymiar austriackiej myśli kodyfikacyjnej i wynik ewolucji rozwiązań będących wspólnym dziedzictwem europejskich systemów prawnych, w tym wyzwania kodyfikacji na poziomie unijnym. Wnioski autorów można ująć krótko w formie twierdzenia: rozwiązania stworzone niemal 100 lat temu nadal funkcjonują w ustawodawstwie i praktyce państw sukcesji habsburskiej oraz w samej Austrii. Zostały one jednak zmodyfikowane i uzupełnione nowymi konstrukcjami. Recypowanie, niemalże w czystej postaci, wzorów austriackich było ciekawym eksperymentem legislacyjnym. Zabieg ten utwierdza w przekonaniu, że tworząc prawo, musimy brać pod uwagę doświadczenia innych: ich błędy i sukcesy. W określonych warunkach historycznych metoda zapożyczeń jest, jak się wydaje, najprostszym i najbardziej efektywnym sposobem osiągania założonych celów. W przypadku krajów, które odzyskały niepodległość po pierwszej wojnie światowej (Czechosłowacji, Jugosławii i Polski), nie było dla niej rozsądnej alternatywy. Co równie ważne, rezultaty dokonanego wyboru przetrwały epokę socjalizmu. Nasuwa się również refleksja, że zjawisko stopniowego rozchodzenia się dróg rozwoju prawa o postępowaniu administracyjnym w tej części Europy ma ograniczony zasięg i nie zagraża właściwej dla tego regionu tradycji.

Wydanie książki zbiegło się z 60. rocznicą uchwalenia polskiego Kodeksu postępowania administracyjnego. Jest to najstarszy spośród obowiązujących obecnie w Polsce kodeksów. To zarazem jeden z najstarszych kodeksów postępowania administracyjnego w Europie. Zaprezentowane w książce rozważania są w jakimś sensie hołdem dla twórców tego aktu i jego odpowiedników w innych państwach sukcesji habsburskiej. 
Mając świadomość wysiłku włożonego w przygotowanie tego zbioru, składam należne podziękowania moim znakomitym kolegom - autorom poszczególnych jego części. Prace redakcyjne nad książką przebiegały w trudnym dla wszystkich czasie pandemii koronawirusa. To dramatyczne zdarzenie uzmysłowiło kruchość ludzkiej egzystencji, lecz w żadnym wypadku nie odebrało nam poczucia wolności myśli i nie podważyło wartości badań komparatystycznych w dziedzinie prawa. Paradoksalnie walka z pandemią odsłoniła ukryte albo mniej znane wcześniej oblicze postępowania administracyjnego - przydatność trybów pilnych i uproszczonych, korzyści płynące ze zmniejszenia stopnia formalizmu procesowego oraz respektowania w toku działań urzędowych zasady pragmatyzmu. Doceniając wkład wielu osób zaangażowanych w powstanie publikacji, muszę podkreślić, że jako jej redaktor naukowy ponoszę pełną i wyłączną odpowiedzialność za wynik podjętego przedsięwzięcia.

Łódź, 15 maja 2020 r.

Zbigniew Kmieciak 


\title{
Chapter I
}

\section{In the Circle of the Austrian Codification Ideas}

\author{
Zbigniew Kmieciak, Ph.D., Full Professor \\ Head of the Department of Administrative Procedure \\ and retired justice of the Supreme Administrative Court \\ University of Łódź, Faculty of Law and Administration \\ zkmieciak@interia.eu
}

(iD https://orcid.org/0000-0002-1297-4940

\section{Evolvement of administrative procedure law}

We can say with certainty that solutions of Spanish and Austrian legal thought have had the greatest impact on development of the administrative procedure law not only in Europe but also outside it. Their underlying foundations were formed in the second half of the 19th and at the beginning of the 20th century. Two codifications of administrative procedure created independently of each other, differing substantially in vision and technique of regulation: Spanish of 1889 (Ley de 19 October 1889 - de Bases de Procedimiento Administrativo) and Austrian of 1925 (Allegemeines Verwaltungsverfahrensgesetz) have become an inspiration for the legislators of other countries. The Spanish Act authorised individual ministers to regulate administrative proceedings within the specified limits. This is one of the things that decided about the framework character of the Law, which is well exposed in its title. Paradoxically, this name came into use only after the Act had entered into force. It was given by a professor at the University of León, Gumersindo Azcárate. ${ }^{1}$ His title expression with the guiding word "bases" indicates indirectly the imperfection of Spanish regulations. In short, the main codification goal, id est relative unification and systematization of legal rules, was not reached. The state of "procedural separatism" was eliminated by re-codification from 1958. Later, in 1992 and 2015, two more codifying events took place. Thus, it follows that the codification model of Spanish origin, which nowadays predominates in many

1 Further A.R. Brewer-Carias, Etudes de droit compare, Bruxelles 2001, p. 164. 
parts of the world, particularly in the Latin American countries, ${ }^{2}$ has evolved gradually for a long time and in a complex way.

The comparative literature presents the view that "Spanish precursor step has been overshadowed by Austria". According to it, this is a country "that is commonly referred to as the real pioneer in administrative procedure codification". In contrast to the fourfold Spanish codification, in Austria it happened just once. Moreover, the statutory regulation from 1925 covered only procedure denoted by an adjective "general" (Allgemeines Verwaltungsverfahrensgesetz). These proceedings were concluded by taking a decision. Such far-reaching homogeneity is not a feature of Spanish acts that went beyond the problem of dealing with individual cases and even procedural law. That is to say, issuing general acts (reglamentos $y$ otras disposiciones administrativas), launching administrative sanctions and system of public administration were also their subject matters. ${ }^{4}$ Administrativecriminal liability and enforcement proceedings in administration were the themes of two Laws passed separately in Austria in 1925. These acts along with the Act on General Administrative Proceedings and the Act implementing new provisions created a coherent system of regulations on administrative operation that broke existing stereotypes. They have remained in force until today. Therefore, the acts in question are not only a "monument of the legal culture" but also a component of law that is undergoing a continual transformation. Attempts are made to compensate for negative consequences of tailoring the letter of the law almost a century old to the current needs with a simple tool, namely publishing uniform texts of acts. The most important amendment to the Acts: on General Administrative Proceedings and Judicial Review of Administration within the revision of the Constitution was made in 2012 by adopting the act called Verwaltungsgerichtsbarkeits-Novelle 2012. This move implied an end of purely cassation formula for adjudicating on legal disputes between administration and an individual, in use since the establishment of the Vienna Administrative Tribunal (Verwalungsgerichtshof) in 1875. At the same time, a legal construct considered the main element of administrative procedure that is an appeal against a settlement of the first instance authority to a higher one was significantly modified. It is important to underscore that such a bold reform, undermining assumptions of the earlier legal order, has not been implemented in any of the European countries aspiring to be successors of $\mathrm{Au}$ strian codification tradition.

2 As regards the legislation of these countries, see R. Perlingeiro (coordenador), F. Alfonso, G. de Caro, A. Frazão, A.G. Costa, C.S. Limade Arruda, M. Ventura Rosa, Procedimento Administrativo e Processo Administrativo Latino. Compilação de Leis Nacionais, Rio de Janeiro 2017.

3 See D. Custos, United States, [in:] Codification of Administrative Procedure, ed. J.-B. Auby, Bruxelles 2014, p. 402.

4 A comprehensive review of these regulations, created as a result of the codification from 2015, is presented in the collection: Régimen Jurídico del Sector Público y Procedimiento Administrativo Comun, director M.Á. Recuerda Girela, Thomson Reuters Aranzadi 2016. 
The universal dimension of Spanish and Austrian codification accomplishments in no way diminishes the role of other countries in developing and modernizaing the existent and creating new institutions of administrative procedure. In particular, European experiences that were collected during the "late flow" of codification and re-codification process make a question about the source of inspiration for national lawmakers, extremely tough (inter alia Sweden 1971, 1986 and 2017, Finland 1982 and again 2003, Italy 1990, Portugal 1991 and again 2015, Holland 1994, Greece and Georgia 1999, France 2015). The outcome of numerous undertakings over the recent decades is unmistakably a resultant of standards promoted by the Council of Europe, requirements of the European Union law, adaptations of extraneous solutions as well as original own concepts. In the face of such high complexity of regulations, some attempts to distinguish codification models and elaborate sufficiently capacious typology of this phenomenon are doomed to failure or at least highly defective. Nevertheless, it is not an obstacle to using a term "model" for scientific description in a looser sense. ${ }^{5}$ One thing is for sure: ideas and concepts straight from Spain and Austria have also found a permanent place in the legal systems in which administrative procedure was codified just a short time ago in a method different from the old formula.

\section{The Austrian legal thought in the Habsburg succession countries}

There is nothing unusual about the fact that shortly after passing of the Act on General Administrative Proceedings in Austria, its solutions were incorporated into the legal order of other countries, originally parts of the Habsburg Monarchy. For practical reasons, mainly due to inherited from the Austrian governing scheme of administrative operation and substantial case law, the codification of administrative procedure was carried in Czechoslovakia and Poland in 1928, while in Yugoslavia in 1930. The Hungarian parliament laws from the period of Austro-Hungarian Monarchy, including the Act no XX of 1901 on Simplification of Administrative Proceedings (a közigazgatási eljárás egyszerüsitéséról szóló), remained in force after the downfall of the empire. An evolvement path other than

5 Such an approach is presented, for example, by D. Coustos, United States, p. 402. He writes about "the Austrian model" that was adopted by several Central-Eastern Europe countries. Similarly, G. della Cananea, Due Process of Law Beyond the State. Requirements of Administrative Procedure, Oxford 2017, p. 23. The author remarks that "The Austrian legislation is based on the model of the judicial process [...]. At the other extreme, it is not so much US Administrative Procedure Act, but the complex of procedural requirements crafted by the courts". 
codification was taken there, to wit, creating piecemeal legislation. Such a regulation was, in the first place, the Act no XXX of 1929 on Administrative Governance (a közigazgatás rendezéséröl szóló). This Law regulated the tiers of public authorities generally, distinguishing two instances of the administrative procedure that reduced the time and cost of dealing with cases. ${ }^{6}$ A great advocate of codification, Zoltán Magyary, argued that the Act no XXX did not regulate a significant range of administrative proceedings. That is why, public authorities developed unwritten, customary rules of operation, and ministers tried to shape them in their own sphere of competence. In his view, this was contrary to the principles of the Rule of Law and administrative rationality. For these reasons, he recommended a codification of general administrative procedure and enforcement proceedings, considering it a "prerequisite of the Rule of Law" and protection of individual rights. ${ }^{7}$ The idea to codify the general administrative proceedings was put forward in Hungary only at the turn of the 1930s and the 1940s. It was realised during the socialism. Therefore, Hungarian pre-codification stage had not the same countenance as in Czechoslovakia, Poland and Yugoslavia. The codification process led undoubtfully to greater legal stability of the states that after many centuries of captivity regained their independence. It provided unification and streamlining operation of officials together with real guarantees for protection of individual rights.

After the Second World War, almost all the Habsburg succession countries encountered a challenge of procedure re-codification. The socialist regime imposed on them a necessity of adjusting previous regulations to new reality or at least demonstrating such intentions. In Poland, this task was completed by modifying some constructions, complementing them with a procedure on citizen complaints and proposals as well as introducing appropriate "ideological ornaments" into the legal provisions. In the original version of the Code of Administrative Procedure of 14 June $1960,{ }^{8}$ "inserts" reflecting the spirit of the regime in power took the form of orders for public authorities to: 1) act "on the basis of legal provisions", with the stipulation that they are to be guided by "the interests of working people and tasks of socialist construction" (Article 4), 2) "guard people's rule of law" (Article $5 a b$ initio). ${ }^{9}$ In specialist writings, nobody explained the meaning of these phrases, in particular, the notion of "tasks of socialist construction" and the difference between "rule of law" in a general sense and "people's rule of law". One of a few studies broaching this problem concluded:

It is the state administration which decides on many important rights and obligations of citizens, organises the service of economic and social needs in a certain area that has a role as a performer

6 J. Szitás, Közigazgatási eljárás, A korszerü közszolgálat útja, Budapest 1939, p. 5.

7 Z. Magyary, A magyar közigazgatás racionalizálása, Budapest 1930, passim.

8 Dziennik Ustaw no. 30/1960, item 168.

9 This aspect of Czechoslovakian codification from 1955 and 1960 is exposed by J. Staša, M. Tomášek, Czech Republic, [in:] Codification of Administrative..., p. 129. 
of state policy guidelines. That is why, there can be no formalistic decisions in its action, although meeting the law requirements, but pointless and sometimes unnecessary. ${ }^{10}$

The quoted phrases were removed from the Code during political changes that began in Poland at the turn of the 1980s and the 1990s.

"Alignment" codifications were undertaken in Czechoslovakia in 1955, 1960 and 1967 (only the last one had the form of an act), in Yugoslavia in 1956 and Poland in 1960. In Hungary, administrative proceedings were codified for the first time in 1957. Administrative procedure law has evolved there - as already highlighted - definitely different from other Habsburg succession countries where the Austrian solutions were strictly replicated and then gradually modified. In Poland, works on the new code began on the tide of "thaw" that was a response to aberrations of Stalinism. At the time, an idea to reactivate the administrative justice system in the shape of the interwar period was put forward but with no acceptance of authorities on political grounds.

With two exceptions (Poland and Slovakia), re-codifications of administrative procedure in the Habsburg succession countries survived only until the political transformation connected with the socialism collapse in the 90s of the 20th century. After desintegration of Czechoslovakia and Yugoslavia related to this event, the new states faced a dilemma of maintaining, at least temporarily, the current legal regime from the federation period or replacing it with another one in the long term. The first variant was chosen in Slovakia. It was decided there only to make successive amendments to the Act of 1967, in force to this day (just ten amendments after 2000, unlike in Poland, where forty changes to the Code of various character were made at that time; it is puzzling that the Croatian Code has not been amended even once, the Slovenian Code has been amended only eight times since the entry into force). The second one was opted for in the Czech Republic and in legal systems that were formerly part of the Yugoslav Federation. For a short time, there were in force the old laws with some slight changes. New codifications took place in Slovenia (1999), Bosnia and Herzegovina (2002), Montenegro (2003), Czechia (2004), Macedonia and Kosovo (2005), Croatia (2009) and Serbia (2016). Re-codifications did not omit other Balkan countries, including Bulgaria (2006) and Albania (2015). Particularly noteworthy is the effort put into the preparation of Hungarian code. Works on the draft Act no CXL of 20 December 2004 on General Principles of Administrative Proceedings and Services (törvény a közigazgatási hatósági eljárás és szolgáltatás általános szabályairól ${ }^{11}$ with the subject, construction and technique of regulation different from the codification model of other postsocialist countries, lasted over a decade. These measures brought an interesting effect, contributing to

10 J. Borkowski, [in:] J. Borkowski (red.), J. Jendrośka, R. Orzechowski, A. Zieliński, Kodeks postępowania administracyjnego. Komentarz, Warszawa 1985, p. 66.

11 Magyar Közlöny no. 203/2004. 
the legal order transformation on a wide-scale. ${ }^{12}$ However, this regulation did not remain in force for too long, because in 2016 a new act was passed that changed dramatically the previous solutions.

\section{Time of attempts and search}

It goes as far as to say that next generations of administrative procedure codification in the Habsburg succession countries are increasingly moving away from their Austrian prototype but they do not discard it. This trend can be easily explained by the will to modernise the procedure, make it an efficient tool for administering and beyond that fully implement the standards stemming from European Union law, recommendations of the Committee of Ministers of the Council of Europe or generally values that underpin the European legal culture. The analysis of the effects of what can be termed the re-codification leads to a conclusion that jurisdictional/adjudicative type proceedings (procedure for adjudication in individual cases in the form of decision) are slowly becoming only one element of a wider bunch of legal procedures, linked by content and function. Forms of these proceedings and their main institutions, including a standing (locus standi), the act terminating the procedure and modes for appeal against administrative actions are undergoing major changes. Consequently, individual decisions and administrative (public-law) contracts are no longer single procedural expressions of administrative activity. A clear tendency to extend this regulation also embraces passing various general acts and undertaking physical acts (keeping registers, issuing certificates or supervising the implementation of decisions). For practical reasons, the grounded principle is to put into the codes provisions on enforcement of administrative acts and sometimes also court judgments in administrative cases. Strictly procedural law is beginning to be suplemennted with another type of regulations, boldly entering the sphere of substantial and structural law. Therefore, not only is the construction of codes changing but also their role. In this situation, the subject matter of their provisions is considerably widening. Aiming to comprise such a complex matter in one act calls for more sophisticated law-making techniques than hitherto, including operating general clauses, references, rules exempting certain groups of provisions and stipulations.Thereby, "systemic" nature of a particular regulation remains unchanged. ${ }^{13}$

12 The background of occurring transformation is presented further by I. Balázs, Eastern Europe in Transition, the Case of Hungary, "Acta Juridica Hungarica" 2012, no. 2, p. 115 and following.

13 Z. Kmieciak, Idea kodyfikacji postępowania administracyjnego z perspektywy państw postsocjalistycznych, "Państwo i Prawo" 2017, no. 9, pp. 33-34. 
The issue of including in the analyzed regulations, provisions regarding enforcement proceedings in administration requires a wider discussion. It has been traditionally, not only in Austria but also in Poland, the subject of separate acts. In turn, the idea of such a new way regularising was conceived in times before the pre-political transformation from the end of the 20th century as an effect of positive experiences. Unlike the extensive, too detailed and intricate regulation introduced by the Polish Act of 17 June 1966 on Enforcement Proceedings in Administration, ${ }^{14}$ its counterparts in the system of Czechia, Slovakia, Hungary and Bulgaria and those of countries of the former Yugoslavia are characterised by concise and abstract formulation of their clauses.

Provisions on enforcement proceedings in administration in new codifications acts count from a few to several dozen editorial units of different sizes (articles also referred to as paragraphs or sections). For example, the Croatian Act of 27 March 2009 on General Administrative Proceedings (zakon o općem upravnom postupku) ${ }^{15}$ contains only 16 articles on enforcement of pecuniary and non-pecuniary obligations. Unlike in Poland, these provisions are only general clauses determining modus procedendi, without detail instructions for officials. Analogically, the Bosnian Act of 25 June 2002 on Administrative Proceedings (zakon o upravnom postupku) ${ }^{16}$ has only a few more of this type of articles. The Bulgarian Administrative Proceedings Code, in force since 12 July 2006, ${ }^{17}$ is the most extensive Balkan regulation on enforcement proceedings. It is composed only of 34 articles but with many provisions. Article 145 of the Croatian Act pertaining to the principle of proportionality perfectly conveys a nature of created clauses. Pursuant to it, the enforcement should be conducted as to use means that are the "most lenient on the enforcement debtor" while ensuring its objectives. It is hard not to pose a question whether the provision so formulated guarantees sufficient authorisation to make judgements by an official who is used to operate in accordance with the strict, measurable criteria determining the line of action.

The downside of code regulation in question (recognised as rational, consistent with modern codification assumptions) is an imperative for the legislature to use some techniques for maintaining its completeness and unequivocally determining the relations between the introduced rules and other enforcement regimes. The Bulgarian legislative tackled this dilemma stating that the code-designated procedure applies to enforceable titles concerning: individual or general administrative acts, judgments, decisions and orders of administrative courts as well as settlements concluded before administrative authorities or courts. ${ }^{18}$

14 Consolidated text - Dziennik Ustaw 2019, item1438.

15 Narodne novine no. 47/2009.

16 Službeni novine Federacije BH no. 29/2002.

17 Vestnik no. 30/2006..

18 Z. Kmieciak, Idea kodyfikacji..., pp. 39-40. 
As already mentioned, provisions on jurisdictional procedure are still the most important but not the only component of codes in the Habsburg succession countries. Over the recent decades, its main principles and institutions of this procedure have undergone a major transformation due to numerous re-codification initiatives. In jurisdictional proceedings individual cases are settled in various modes: decisional, conciliatory or contractual, formalized (standard), simplified or automatic, ordinary or extraordinary, with mediation or beyond it. However, requirements under the general code rules should always be respected. Common practice is to distinct these principles by giving titles depicting a protected value, most often provided for in the constitution. They correspond or even overlap with the European standards of Good Administration being in turn a reflection of the idea of due (fair) process. ${ }^{19}$ Some of these principles apply not only to adjudicating but also to other types of administrative activity.

There is a clearly visible fact of "replacing" code regulations by special provisions full of procedural peculiarities, as a disguised form of administrative procedure decodification by using the "bypasses" technique. ${ }^{20}$ Article 2 of the Bosnian Act can be given as an example of the legislative efforts to stop this phenomenon. According to it, in specific spheres of administration, only exceptionally there is a possibility of regulating individual procedural issues by other acts differently than it is adopted in the Act. However, even then regulations considered as lex specialis to the Act on Administrative Proceedings "may not be in contradiction to the principles of this Law". A similar construction is shaped by the Serbian Act of 29 February 2016 on General Administrative Proceedings (zakon o opštem upravnom postupku). ${ }^{21}$ Article 3 of the Act refers to its fundamental principles and complements a requirement for consistency with such standards by the stipulation that a special provision "does not lower the level of protection of rights and legal interests of parties guaranteed by this act". The Bosnian Act also mandates the subsidiary application of its provisions in cases that are subject to special procedural regime on condition that it does not cover a given issue (Article 3).

Provisions of the laws under examination define a party to proceedings in a way corresponding to the Austrian solutions, taking the concept of rights, freedoms, obligations and legal interests as key elements of this institution. Some of them provide protection that branches out from the previously established regime to some extent. This statement can be referred to parties in a formal sense within the

19 As for the concept of administrative due process, see K. Werhan, Principles of Administrative Law, St. Paul 2008, pp. 107-157 and G. della Cananea, Due Process..., p. 139 and following.

20 From works on this subject, see in particular Li Zhang, China, also T. Barkhuysen, W. den Ouden, Y.E. Schuurmans, Netherlands - both studies were included in the collection: Codification of Administrative..., respectively pp. 102 and 266-267; from Polish publications - J. Zimmermann, Aksjomaty prawa administracyjnego, Warszawa 2013, p. 188 and Z. Kmieciak, Zarys teorii postępowania administracyjnego, Warszawa 2014, p. 69 and following.

21 Službeni glasnik RS no. 18/2016. 
meaning of the provisions of $\S 15$ part 3 of the Hungarian Act of 2004 not valid any more, as well as, under Article $4 \$ 2$ of the Croatian Act to groups of persons associated by a common interest, referring to their rights and obligations which require a resolution in administrative proceedings.

As a rule, it is accepted that a decision as an act resolving an individual case has two alternatives: a settlement concluded between parties to administrative proceedings and a contract between a party and an authority. The character of the last-mentioned institution is signalled by adjectives: "administrative" or "public-law". This tool for fulfilling administrative tasks is subject to some constraints of use. Under the Croatian Act, a contract may not conflict with the operative parts of decision and mandatory provisions of law, public interest or cause detriment to third parties. If it is to have legal consequences for them, its validity requires their written consent (Article $150 \$ 3$ ). The Czech Act no 500 of 24 July 2004 on Administrative Proceedings (správní rád) 22 generally states that a contract may not be contrary to the law or concluded in order circumvent it. Moreover, it has to be consistent with the public interest ( $\$ 159$ part 2 ). Presenting more restrictive approach, the Croatian Act indicated granting an appropriate permission by law as a precondition for using the form of administrative contract (Article $150 \$ 1$ in fine). An equivalent reservation was found in the Hungarian Act of 2004 ( $\$ 76$ part 1 ). It is worth adding that to facilitate the use of consensual forms in administrative proceedings, the institution of a liaison official (hatósági közvetítö) was introduced by the Act. Administrative authorities are empowered to engage in this position people holding appropriate qualifications to enhance resolving disputes between them and parties to proceedings (vertical disputes) and between parties with conflicting interests (horizontal disputes). The Act rendered the official responsible for providing reliable and up-to-date information in the language that addressees understand concerning: the subject of the proceedings, their anticipated outcome and all necessary measures to prevent adverse effects for parties. Furthermore, their task is to conduct a mediation in each of the distinguished layouts (vertical and horizontal), to find a solution for achiving the objective to the proceedings "for the benefit" of all interested parties.

Another special feature of the discussed Hungarian Act is the mode of monitoring the compliance with law and exercise of rights and obligations based on decisions with enforceability attribute. The Law allowed for a possibility of conducting the administrative control (periodic, permanent or ordinary) ex officio or on request only when it is not excluded by acts or governmental orders. ${ }^{23} \mathrm{It}$ became the subject of the Act no CL of 2016 - the General Code of Administrative

22 Sbírka zákonů ČR no. 500/2004.

23 Further Z. Kmieciak, Węgierska ustawa o ogólnych zasadach postępowania w sprawach administracyjnych - koegzystencja dwóch wizji porządku prawnego?, "Państwo i Prawo" 2017, no. 4, pp. 31-32. 
Proceedings (törveny az általános közigazgatási rendtartásról). ${ }^{24}$ This re-codifying Act introduced administrative audit regime (\$98-102). It cannot be a coincidence that such regulations are part of the draft Model of Administrative Proceedings of the European Union prepared by the ReNEUAL Group that was constituted in 2009 (Book III - Issuing Decisions in Individual Cases). After all, audits provides data for secondary evidence verification in cases already dealt with, in particular credibility of a party statements or information necessary to evaluate their compliance with their obligations based on particular acts (decision, settlement or administrative contract), for example respecting conditions of granted permissions. Sometimes, audits also initiates a procedure in a new case before an administrative authority or other entity. Due to this dependence (connection between control activities and activation of appropriate sanctions), the purposefulness of incorporating regulations on audit into the law on administrative procedure should not be contested.

At present, it is undisputed that provisions of jurisdictional procedure are not only to create appropriate guarantees for the protection of individual rights and interests but also ensure the effectiveness of administrative undertakings. ${ }^{25}$ That is why legislative changes should take into account the ideas and principles of "good governance", requirements of economic calculation, inconveniences connected with participation of various entities in the procedure and time allocated to settle a case, including a resolution of any court dispute arising against this background. ${ }^{26}$ In some administrative areas, this gives rise to the necessity of resigning from the overly formalized, comparable to judicial procedure, modes for dealing with individual cases and replacing them with summary ones.

The Croatian Act departs from the concept of regulating administrative procedure in detail and thereby constantly increasing the level of its rigorism. It establishes two basic regimes for adjudicating on individual cases: 1) standard (full), 2) summary. The latter procedure of taking a decision (Articles 48-50) is applied when material facts of a case can be reconstructed just at the time of initiating the proceedings without a need for explanatory activities and hearing a party. It is available only on matters listed by the statutes in which parties with conflicting interests do not participate. The regulation is complemented by the provisions on

24 Maygar Közlöny no. 200/2016.

25 See for instance A.R. Brewer-Carias, Principios generales del procedimiento administrativo: hacia un estándar continental, [in:] Procedimiento y justicia administrativa en América Latina, ed. C. Steiner, Mexico 2009, p. 183-184 and Z. Kmieciak, Pragmatyzm postępowania administracyjnego, [in:] Fenomen prawa administracyjnego. Księga Jubileuszowa Profesora Jana Zimmermanna, red. W. Jakimowicz, M. Krawczyk, I. Niżnik-Dobosz, Warszawa 2019, p. 498 and following.

26 Further I. Koprić, Administrative Technology and General Administrative Procedure: Challenges and Changes in South-Eastern Europe, "Hrvatska i Komparativna Javna Uprawa" 2010, no. 1 , pp. 447-449. 
deadlines for settling a case and legal consequences for administrative authority if they are missed (Articles 101-102). Unless otherwise stipulated, a decision in summary procedure is to be issued and delivered to an addressee without delay, but not later than within 30 days of putting forward a request. In cases enumerated in the special provisions, a failure to meet a statutory deadline for resolving a case is tantamount to acceptance of a request submitted in a proper way (tacit settlement of a case). The literature underlines that implementation of such constructions provided highly effective protection of party rights "but only in areas determined as appropriate by the legislature". ${ }^{27}$ The Hungarian Act of 2016 has a similar regime (§ 39-43). Beside a standard and a summary mode, it distinguishes an automatic decision-making procedure. Under Article 50 of the Act, if this mode is launched, a case is dealt within 24 hours (in full procedure within a maximum period of 60 days, in summary one within 8 days).

Solutions adopted by the Czech Act have also the characteristics of summary procedure. "Proceedings on site" (řízení na místě) regulated in various parts of the Act are deemed as such. ${ }^{28}$ In accordance with the provision of $\$ 143$ part 2 , "the prerequisite for imposing a duty on site shall be the finding of facts of the case". A decision is declared orally, however its written form is delivered without delay. Unless the special law provides otherwise, an appeal against a decision has no suspensive effect. The Act prescribes, that "a decision declared orally shall be confirmed in writing on site by the administrative authority when participant so requests" (\$67 part 3).

In Poland, regulations on the summary procedure were added to the Code of Administrative Procedure due to its significant amendment from 2017. Considering the risk of infringing parties' interests, in Article 163d of the Code, the circumstances justifying the case transfer from summary to full procedure are identified. ${ }^{29}$

Different variations of summary procedure are also well known to the legislation of other countries, including common law systems. In the USA, under the rule of the federal Administrative Procedure Act of 1946, they are described as "procedural shortcuts": 1) official notice of material facts replacing formal hearing of evidence, 2) summary judgment procedure. ${ }^{30}$ It should be stressed that using these types of proceedings is not free of controversy. There are many opinions that the first one may violate the right of a party to a fair administrative hearing derived

27 D. Đerđa, Republic of Croatia, [in:] Codification of Administrative..., p. 118.

28 See M. Szubiakowski, Postępowanie uproszczone - nowa instytucja polskiej procedury administracyjnej, [in:] Idea kodyfikacji w nauce prawa administracyjnego procesowego. Księga pamiątkowa Profesora Janusza Borkowskiego, red. Z. Kmieciak, W. Chróścielewski, Warszawa 2018, pp. 326-327.

29 Further Z. Kmieciak, [in:] Kodeks postępowania administracyjnego. Komentarz, red. Z. Kmieciak, W. Chróścielewski, Warszawa 2019, pp. 913-914.

30 See E. Gellhorn, R.M. Levin, Administrative Law and Procedure in a Nutshell, St. Paul 2006, p. 298 and following, also D. Custos, United States, pp. 387-388. 
from the constitutional due process clause. For this reason, court judicature has developed the criteria that a particular action has to fulfil to be considered legal. These requirements specify the rule of the Administrative Procedure Act by which in a situation when an agency's decision is based on official notice findings, a party should be given a mainingful chance to rebut them (to show the contrary view). According to the well-established case law, the data known to agency has to be always defined in detail, including a source of gathered information. A party should have a real, not only purely theoretical chance to verify the findings, as well as expose their arguments. ${ }^{31}$ These case law principles do not diverge from the European standard we are familiar with.

The order of efficiency, explicitly expressed in general principles of the laws on administrative procedure in the Habsburg succession countries is quite difficult to reconcile with the over-elaborated system for verifying administrative acts issued in both ordinary and extraordinary regimes. Unsurprisingly, there is determination in many parts of Europe to rationalise the mechanisms for protecting individual rights and search for solutions adequate to conditions in which modern administration performs its tasks. It was put into effect by breaking with the vision of devolutionary remedy as the only way to appeal in administrative procedure. Of course, there are some opinions that an appeal to the same authority that took a contested decision (non-devolutionary appeal) is a defective remedy because it triggers quasi-two-tier proceedings deprived of such impartial adjudication guarantees like a "real" two-instance procedure has. ${ }^{32}$ Nevertheless, both the legislature and practice have found a way to lessen this inconvenience through the principle of internal devolution of competences. For example, it is effectuated by Article 122 of the Croatian Act concerning an objection as a form of appeal against a decision. This provision stipulates that a head of authority is competent to hear a non-devolutionary appeal. A comparable construction (rozklad) is known to Slovak law, enshrined in $\$ 61$ of the Czechoslovak Act no 71 of 29 June 1967 on Administrative Proceedings (zakon o správnom konani (správny poriadok). ${ }^{33} \mathrm{~A}$ head of central authority issues a decision within the mode specified in that provision after considering an opinion of the special committee as an advisory body. Meanwhile, the Constitutional Tribunal of Hungary admitted still in the 1990s that the right to appeal takes various forms. Expanding its thesis, the Tribunal clarified that it is translated into cognizance of a case by an authority other than the one that rendered the decision or "at a higher instance by the same authority" ${ }^{34}$

31 E. Gelhorn, R.M. Levin, Administrative Law..., pp. 303-304.

32 See V. Cucić, Administrative Appeal in Serbian Law, "Transylvanian Review of Administrative Sciences" 2011, no. 32E, pp. 60-61.

33 Zbierka zákonov Československej socialistickej republiky no. 71/1967.

34 As cited in: A. Paulovics, Guarantees of the Legality of Administration and Administrative Procedure in Hungary, "DANUBE/Law and Economics Review" 2011, no. 2, p. 48. In this connection a concept according to which an administrative appeal is always devolutive should be 
Broadening the scope of control exercised as a result of lodging a remedy through administrative mode is no less interesting phenomenon. According to new generation legislation, this verification also covers activities other than issuing administrative acts such as individual decisions. This observation is illustrated by the objection institution (prigovor) within the Serbian Act meaning (Articles 147-150). This Law separately regulates the right to appeal against an administrative decision (pravo na žalbu).

\section{Questions about the formula of administrative procedure codification}

In the opinion of one of the most famous Polish theoreticians,

on a comparative level, we can draw lessons [...] that a country having a codified administrative procedure will never decide later to return, for whatever reason, to the old system of fragmented regulations, to true "procedural freedom" of public administration. ${ }^{35}$

Therefore, if legislative amendments already take place, they are usually unidirectional, focused on creating more and more extensive, detailed, intricate and complicated rules in the hope that they will prove effective. ${ }^{36}$ Counter movements are uncommon, specially in countries with a long-standing codification tradition. However, maybe just this policy (giving up casuistry in favour of more general clauses determining wide range of flexibility for administrative authorities and courts) is a right response to commonly observed legislative failures. We do need to face up to the fact that the obvious trend towards the law "streamlining" is sometimes at the cost of transparency and utility. Another matter to raise: how long will the recodified legal constructions outlast in legal systems where the Austrian ideas were once adopted? Will the legislature be able to resist the temptation

considered as isolated - for more on remedy understood in this way, see P. Kovač, Effective Adjudication through Administrative Appeals in Slovenia, "Utrecht Law Review" 2013, vol. 9, issue 3, p. 43.

35 G. Langrod, Genése et lignes directrices de la réforme de la procédure administrative non contentieuse en Pologne, "Revue Internationale des Sciences Administratives" 1960, no. 4, p. 399. See also remarks concerning "the living without GAPA" (general administrative procedure acts) - J.-B. Auby, General Report, [in:] Codification of Administrative..., pp. 27-28.

36 See, for instance, reflections on Slovenian experiences - P. Kovač, The Requirements and Limits of the Codification of Administrative Procedure in Slovenia According to European Trends, "Review of Central and East European Law" 2016, vol. 41, pp. 448-449. The author does not hide that procedural regulation in administrative matters is over-formalized and detailed. 
of easy amendments to regulations, dictated by need of a while? And further, in this context: whether the codification acts which once governed only an adjudicating mode in individual cases are not today becoming "codes of administrative activity" or even "codes of administration and control over it"? The Netherlands Act of 1994, the Georgian Act of 1999 and the Bulgarian Act of 2006 are good examples of the latter type of codification. Perhaps, the analysed legislative action is the first stage codification of "general administrative law". ${ }^{37}$ The problem is that attempts to pass a bill in this regard in Poland were unsuccessful several times. ${ }^{38}$

The collapse of the Habsburg Empire in 1918 debunked the myth of the "Community of Nations" cultivated there. ${ }^{39}$ However, it did not undermine the achievements of legal thought of the 19th and early 20th century taken into account when creating legal constructs of the Habsburg succession countries. This legacy has become a part of the cultural heritage and an element that has permanently entered the national legal orders. An esteemed researcher in the field of the Habsburg history concludes: even as the monarchy formally ceased to exist, "common elements of empirial practice continued to shape many peoples' expectations". Prominent politicians of the succession countries "often adopted familiar laws, practices and institutions for their new states. At the same time, however, they loudly rejected any legacy of empire as incompatibile with democracy and national self-determination" 40

Zbigniew Kmieciak Ph.D., Full Professor. Head of the Department of Administrative Procedure - Faculty of Law and Administration, University of Łódź, and retired justice of the Supreme Administrative Court. Author of about three hundred scientific publications and many legal opinions developed for the legislative process and practice needs. Leader of the expert group on the reform of Law of Administrative Procedure in the years 2012-2016. Group's activities contributed to the essential modernization of the Polish Code of Administrative Procedure of 2017.

37 A.R. Brewer-Carias presents the implementation of this idea in one of the Latin American countries, namely Costa Rica through the Act: Ley General de la Administración Pública, see: Principios generales..., p. 165.

38 See General Provisions of Administrative Law - Grounds for the Draft of a Bill, [in:] Prawo do dobrej administracji, Biuletyn RPO. Materiały, no. 60, Warszawa 2008, p. 215 and following.

39 Further P. M. Judson, The Habsburg Empire. A New History, Cambridge (Massachusetts)-London (England) 2016, pp. 15-19, 88-89, 447 and following.

40 P.M. Judson, The Habsburg Empire..., p. 23. 


\section{Rozdział I}

\section{W kręgu austriackich idei kodyfikacyjnych}

Zbigniew Kmieciak, prof. dr hab.

Kierownik Katedry Postępowania Administracyjnego

i sędzia Naczelnego Sądu Administracyjnego w stanie spoczynku

Uniwersytet Łódzki, Wydział Prawa i Administracji

zkmieciak@interia.eu

iD https://orcid.org/0000-0002-1297-4940

\section{Drogi ewolucji prawa o postępowaniu administracyjnym}

Największy wpływ na rozwój prawa o postępowaniu administracyjnym nie tylko w Europie, lecz także poza nią, wywarły niewątpliwie rozwiązania będące wytworem hiszpańskiej i austriackiej myśli prawnej. Ich zasadnicze zręby i założenia zostały ukształtowane w drugiej połowie XIX i na początku XX w. Dwie dokonane niezależnie od siebie, różniące się znacznie koncepcją i techniką regulacji, kodyfikacje postępowania administracyjnego - hiszpańska z 1889 r. (Ley de 19 de octubre de 1889 - de Bases de Procedimiento Administrativo) i austriacka z 1925 r. - stały się impulsem do działań legislatywy innych państw. Ramowy charakter ustawy hiszpańskiej, zawierającej upoważnienia dla poszczególnych ministrów do unormowania postępowań administracyjnych w wyznaczonych przez nią granicach, dobrze oddaje nazwa tego aktu. Paradoksalnie nazwa ta zaczęła być powszechnie używana dopiero po wejściu ustawy w życie, za sprawą profesora Uniwersytetu w León - Gumersindo Azcárate ${ }^{1}$. Stworzone przez niego określenie, którego kluczowym elementem jest słowo „podstawy”, wskazuje pośrednio na niedoskonałość wprowadzonych wówczas regulacji. Nie realizowały one głównej idei wszelkich poczynań kodyfikacyjnych, którą jest względna unifikacja i systematyzacja porządku prawnego. Stan swoistego „separatyzmu proceduralnego" wyeliminowano,

1 Szerzej A.R. Brewer-Carias, Études de droit comparé, Bruxelles 2001, s. 164. 
kodyfikując powtórnie postępowanie administracyjne w 1958 r. Kolejne zabiegi kodyfikacyjne $\mathrm{w}$ tym przedmiocie przeprowadzono $\mathrm{w}$ Hiszpanii jeszcze dwukrotnie: w 1992 i 2015 r. Płynie z tego wniosek, że model kodyfikacji o hiszpańskim rodowodzie, który współcześnie dominuje w wielu częściach świata, przede wszystkim w państwach Ameryki Łacińskiej², powstawał stopniowo, w toku długiej i uwarunkowanej złożonymi czynnikami ewolucji.

W literaturze komparatystycznej prezentowana jest teza, że wskazane wcześniej „prekursorskie posunięcie hiszpańskie zostało przyćmione przez Austrię” („the Spanish precursor step has been overshadowed by Austria"). Podkreśla się przy tym, że właśnie to państwo „postrzegane jest powszechnie jako rzeczywisty pionier kodyfikacji postępowania administracyjnego" („that is commonly referred to as the real pioneer in administrative procedure codification") $)^{3}$. W odróżnieniu od Hiszpanii, w której dzieło kodyfikacji postępowania administracyjnego podejmowano czterokrotnie, w Austrii poprzestano na jednorazowym zabiegu określanym tym pojęciem. Co więcej, zakresem regulacji ustawowej z 1925 r. objęto jedynie postępowanie $\mathrm{w}$ sprawach indywidualnych rozstrzyganych $\mathrm{w}$ formie decyzji oznaczone przymiotnikiem „ogólne” (Allgemeines Verwaltungsverfahrensgesetz).

O tak daleko posuniętej jednorodności normowanej materii nie sposób mówić w przypadku ustaw hiszpańskich. Zamieszczono w nich także przepisy wykraczające poza problematykę prawa procesowego, $w$ tym trybu załatwiania spraw indywidualnych, odnoszące się m.in. do wydawania aktów generalnych (reglamentos $y$ otras disposiciones administrativas), sankcji administracyjnych i ustroju administracji publicznej ${ }^{4}$.

Przedmiotem uchwalonych odrębnie w Austrii w 1925 r. dwóch ustaw stały się zagadnienia odpowiedzialności karnoadministracyjnej i postępowania egzekucyjnego w administracji. Wraz z ustawą o ogólnym postępowaniu administracyjnym i ustawą wprowadzającą nowe przepisy stworzyły one koherentny, burzący dotychczasowe stereotypy, system uregulowań dotyczących działalności organów administracji. Akty te zachowały do dziś moc obowiązującą. Nie są więc one tylko „pomnikiem kultury prawnej”, lecz również podlegającym stałym przeobrażeniom składnikiem porządku prawnego. Negatywne konsekwencje dostosowywania „litery prawa" sprzed niemal 100 lat do współczesnych potrzeb próbuje się kompensować, stosując prosty środek - publikując teksty jednolite ustaw. Najważniejszej zmiany przepisów ustaw: o ogólnym postępowaniu administracyjnym oraz

2 Co do ustawodawstwa tych państw zob. R. Perlingeiro (coordenador), F. Alfonso, G. de Caro, A. Frazão, A.G. Costa, C.S. Limade Arruda, M. Ventura Rosa, Procedimento Administrativo e Processo Administrativo Latino. Compilação de Leis Nacionais, Rio de Janeiro 2017.

3 Zob. D. Custos, United States, [w:] Codification of Administrative Procedure, ed. J.-B. Auby, Bruxelles 2014, s. 402.

4 Szeroki przegląd tego zespołu uregulowań, ukształtowanych w wyniku kodyfikacji z 2015 r., przedstawiono w zbiorze: Régimen Jurídico del Sector Público y Procedimiento Administrativo Comun, director M.Á. Recuerda Girela, Thomson Reuters Aranzadi 2016. 
o sądowej kontroli administracji, łączącej się z rewizją postanowień Konstytucji, dokonano w 2012 r. przez uchwalenie aktu nazwanego Verwaltungsgerichtsbarkeits-Novelle 2012. Decydując się na ten krok, zerwano z utrzymywaną od czasu utworzenia w 1875 r. wiedeńskiego Trybunału Administracyjnego (Verwalungsgerichtshof) formułą czysto kasacyjnego orzekania w sprawach sporów sądowych jednostki $\mathrm{z}$ administracją. Zmodyfikowano zarazem istotnie konstrukcję uznawaną za główny element postępowania administracyjnego, czyli zaskarżenie rozstrzygnięcia organu pierwszej instancji odwołaniem kierowanym do organu wyższego stopnia. Wypada podkreślić, że w żadnym z państw europejskich, uważających się za kontynuatorów austriackiej tradycji kodyfikacyjnej, nie wprowadzono tak odważnej i podważającej założenia wcześniejszego porządku prawnego reformy.

Uniwersalny wymiar dokonań kodyfikacyjnych Hiszpanii i Austrii nie umniejsza w żadnym wypadku roli innych państw w rozwijaniu i modernizacji istniejących oraz tworzeniu nowych instytucji prawa o postępowaniu administracyjnym. Zwłaszcza doświadczenia europejskie zgromadzone w związku z „późną falą” kodyfikacji i procesem rekodyfikacji (m.in. Szwecja w roku 1971, 1986 i 2017, Finlandia 1982 i powtórnie 2003, Włochy 1990, Portugalia 1991 i powtórnie 2015, Holandia 1994, Grecja i Gruzja 1999, Francja 2015) czynią niezwykle trudnym pytanie o źródła inspiracji krajowej legislatywy. Nie będzie zapewne błędem stwierdzenie, że wynik wielu przeprowadzonych w ostatnich dziesięcioleciach zabiegów jest wypadkową standardów promowanych przez Radę Europy, wymagań prawa unijnego, adaptacji obcych rozwiązań oraz oryginalnych, własnych koncepcji. Wobec tak dużej złożoności uregulowań w sferze postępowania administracyjnego, podejmowane przez teorię próby wyodrębnienia modeli kodyfikacji albo wypracowania dostatecznie pojemnej typologii tego zjawiska wydają się być z góry skazane na niepowodzenie lub co najmniej wysoce ułomne. Okoliczność ta nie jest wszakże przeszkodą do używania dla celów opisu naukowego pojęcia „model” w bardziej luźnym znaczeniu 5 . Jedno jest pewne: również w systemach prawnych, w których kodyfikację postępowania administracyjnego przeprowadzono stosunkowo niedawno, w sposób odbiegający od ukształtowanej przed wielu laty formuły, idee i pomysły rodem z Hiszpanii i Austrii znalazły trwałe miejsce.

5 Ujęcie to prezentuje chociażby D. Coustos, United States, s. 402. Pisze on o „austriackim modelu" (the Austrian model), który przyjęło kilka państw Europy Środkowo-Wschodniej. Podobnie G. della Cananea, Due Process of Law Beyond the State. Requirements of Administrative Procedure, Oxford 2016, s. 23. Autor zauważa, że ustawodawstwo austriackie wzorowane jest na modelu procesu sądowego. Odmienne założenia przyświecały amerykańskiej kodyfikacji postępowania administracyjnego, jednak w tym przypadku „kompleks wymagań proceduralnych został ukształtowany przez sądy” (,the complex of procedural requirements crafted by the courts"). 


\section{Recypowanie dorobku austriackiej myśli prawnej w państwach sukcesji habsburskiej}

Nie jest czymś niezwykłym fakt, że wkrótce po uchwaleniu w Austrii ustawy o ogólnym postępowaniu administracyjnym przyjęte w niej rozwiązania włączono do porządku prawnego innych państw będących wcześniej częścią Monarchii Habsburskiej. Z powodów praktycznych, głównie z uwagi na utrwalony już, odziedziczony po rządach austriackich, schemat funkcjonowania administracji i bogaty dorobek case law, w 1928 r. przeprowadzono kodyfikację postępowania administracyjnego w Czechosłowacji i w Polsce, zaś w 1930 r. w Jugosławii. Na Węgrzech, ze zrozumiałych powodów, po pierwszej wojnie światowej zachowały moc obowiązującą akty parlamentu węgierskiego z okresu istnienia Monarchii Austro-Węgierskiej, w tym ustawa nr XX z 1901 r. o uproszczeniu postępowania administracyjnego (a közigazgatási eljárás egyszerüsitéséról szóló). Nie zdecydowano się tam na wariant kodyfikacji, wybierając inną drogę - rozwijania fragmentarycznych uregulowań procesowych. Tego rodzaju unormowania znalazły się przede wszystkim w ustawie nr XXX z 1929 r. o zarządzaniu administracyjnym (a közigazgatás rendezéséröl szóló). Ustawa ta określiła szczeble organizacyjne administracji ogólnej, wyodrębniając dwie instancje postępowania, co ograniczyło czas i koszty załatwiania spraw ${ }^{6}$. Wielki orędownik kodyfikacji, Zoltán Magyary, argumentował, że ustawa nr XXX z 1929 nie uregulowała znacznego zakresu postępowania administracyjnego. Dlatego organy administracji rozwijały niepisane, zwyczajowe zasady działania, zaś poszczególni ministrowie starali się określać je w sferze swojej właściwości. W jego ocenie, ten stan rzeczy pozostawał w sprzeczności z zasadami praworządności i racjonalności administrowania. $\mathrm{Z}$ tych powodów zalecał on kodyfikację ogólnego postępowania administracyjnego i postępowania egzekucyjnego, uznając to za „przesłankę rządów prawa” i ochrony praw jednostki Koncepcję kodyfikacji ogólnego postępowania administracyjnego przygotowano na Węgrzech dopiero na przełomie lat trzydziestych i czterdziestych ubiegłego wieku, zaś zrealizowano ją - w odmiennym kształcie - w czasach socjalizmu. Przedkodyfikacyjne stadium miało tam więc inne oblicze niż w Czechosłowacji, Polsce i Jugosławii. W warunkach państw, które po trwającym niekiedy wieki zniewoleniu odzyskały niepodległość, urzeczywistnienie idei kodyfikacji prowadziło niewątpliwie do większej stabilizacji prawnej. Dokonany zabieg umożliwił unifikację i usprawnienie działań urzędników, przy zapewnieniu jednostce realnych gwarancji ochrony jej praw.

Po drugiej wojnie światowej niemal wszystkie państwa sukcesji habsburskiej zetknęły się z wyzwaniem powtórnej kodyfikacji postępowania administracyjnego.

6 J. Szitás, Közigazgatási eljárás, A korszerü közszolgálat útja, Budapest 1939, s. 5.

7 Z. Magyary, A magyar közigazgatás racionalizálása, Budapest 1930, passim. 
Narzucenie im ustroju socjalistycznego pociągnęło za sobą konieczność dostosowania uregulowań prawa procesowego do nowych realiów lub przynajmniej zademonstrowania takich intencji. W Polsce wywiązano się z tego zadania, modyfikując pewne konstrukcje i uzupełniając je procedurą w przedmiocie skarg i wniosków obywatelskich oraz wprowadzając do przepisów prawa stosowne „ozdobniki ideologiczne”. W pierwotnej wersji ustawy z 14 czerwca 1960 r. - Kodeks postępowania administracyjnego ${ }^{8}$,wstawki” oddające ducha panującego ustroju przybrały postać nakazów: 1) działania przez organy administracji „na podstawie przepisów prawa”, z zastrzeżeniem, że mają się one kierować „interesem ludu pracującego i zadaniami budownictwa socjalistycznego” (art. 4); 2) stania przez te organy „na straży praworządności ludowej” (art. $5 a b$ initio) ${ }^{9}$. W literaturze naukowej nikt nie wyjaśnił bliżej sensu tych zwrotów, precyzując np. co mieści się w pojęciu „zadań budownictwa socjalistycznego” i do czego sprowadza się różnica między „praworządnością” w ogólnym znaczeniu i „praworządnością ludową”. W jednym z nielicznych opracowań, w których poruszono ten problem, wskazano, co następuje:

Właśnie administracji państwowej, która rozstrzyga o wielu ważnych prawach i obowiązkach obywateli, także organizuje zaspokojenie potrzeb gospodarczych i społecznych na danym terenie, przypada rola wykonawcy założeń polityki państwa. Dlatego nie może w jej działaniu być decyzji formalistycznych, wprawdzie odpowiadających wymaganiom stawianym przez przepisy prawne, ale niecelowych, a czasem zbędnych ${ }^{10}$.

Wskazane frazy usunięto z kodeksu w toku przemian ustrojowych zapoczątkowanych w Polsce na przełomie lat osiemdziesiątych i dziewięćdziesiątych ubiegłego stulecia.

Kodyfikacji „dostosowujących” dokonano w Czechosłowacji w 1955, 1960 i 1967 r. (tylko ostatniej z nich nadano formę ustawy), w Jugosławii w 1956 r., a w Polsce w 1960 r. Na Węgrzech pierwszy raz skodyfikowano postępowanie administracyjne w 1957 r. Droga ewolucji prawa o postępowaniu administracyjnym przebiegała tam - o czym już wspomniano - zdecydowanie inaczej niż w pozostałych państwach sukcesji habsburskiej, w których recypowano wprost rozwiązania austriackie i później stopniowo je modyfikowano. Prace nad nowym kodeksem podjęto w Polsce na fali „odwilży” będącej reakcją na wynaturzenia stalinizmu. Wysunięto wówczas pomysł reaktywowania sądownictwa administracyjnego według kształtu z okresu międzywojennego, którego jednak władza z przyczyn politycznych nie zaakceptowała.

Powtórne kodyfikacje postępowania administracyjnego w państwach sukcesji habsburskiej przetrwały, poza dwoma wyjątkami (Polska i Słowacja), tylko do

8 Dziennik Ustaw nr 30/1960, poz. 168.

9 Ten aspekt kodyfikacji czechosłowackich z lat 1955 i 1960 eksponują J. Staša, M. Tomášek, Czech Republic, [w:] Codification of Administrative..., s. 129.

10 J. Borkowski, [w:] J. Borkowski (red.), J. Jendrośka, R. Orzechowski, A. Zieliński, Kodeks postępowania administracyjnego. Komentarz, Warszawa 1985, s. 66. 
czasu transformacji ustrojowej wywołanej upadkiem socjalizmu w latach dziewięćdziesiątych XX w. Po związanym z tym wydarzeniem rozpadzie Czechosłowacji i Jugosławii, nowe państwa stanęły dodatkowo przed dylematem utrzymania, przynajmniej przez pewien okres, dotychczasowego reżimu prawnego $\mathrm{z}$ okresu federacji lub zastąpienia go docelowo innym. Pierwszą z tych opcji wybrano na Słowacji, poprzestając na kolejnych nowelizacjach obowiązującej do dziś ustawy z 1967 r. (po 2000 r. uczyniono to tylko dziesięciokrotnie; dla porównania, w Polsce dokonano w tym czasie 40, o różnym charakterze, zmian kodeksu; jest rzeczą zastanawiającą, że od czasu wejścia w życie kodeks chorwacki nie został zmieniony ani razu, zaś kodeks słoweński - tylko 8 razy). Na drugi z wyróżnionych wariantów zdecydowano się w Czechach i w systemach prawnych, które wcześniej były częścią federacji jugosłowiańskiej. Przez krótki czas obowiązywało tam, z niewielkimi poprawkami, dawne ustawodawstwo. Nowych kodyfikacji w ramach powstałych systemów prawnych dokonano w Słowenii w 1999 r., w Bośni i Hercegowinie w 2002 r., w Czarnogórze w 2003 r., w Czechach w 2004 r., w Macedonii i w Kosowie w 2005 r., w Chorwacji w 2009 r., zaś w Serbii w 2016 r. Ponowne kodyfikacje nie ominęły również innych państw bałkańskich. Zabiegi te przeprowadzono w Bułgarii w 2006 r. i w Albanii w 2015 r. Na uwagę zasługuje wysiłek włożony w przygotowanie kodyfikacji węgierskiej. Prace nad projektem ustawy nr CXL z 20 grudnia 2004 r. o ogólnych zasadach postępowania administracyjnego i usługach (törvény a közigazgatási hatósági eljárás és szolgáltatás általános szabályairól l) ${ }^{11}$, znacząco różniącej się przedmiotem, konstrukcją i techniką unormowania od obowiązujących w pozostałych państwach postsocjalistycznych aktów rangi kodeksowej, trwały ponad dekadę. Działania te przyniosły interesujący efekt, wpisując się w zakrojony na szerszą skalę proces zmian ładu prawnego ${ }^{12}$. Regulacja ta nie przetrwała jednak zbyt długo, gdyż w 2016 r. uchwalono kolejną ustawę, odstępując od poprzednich rozwiązań lub modyfikując je.

\section{Czas prób i poszukiwań}

Można zaryzykować twierdzenie, że kolejne generacje kodyfikacji postępowania administracyjnego przeprowadzanych $\mathrm{w}$ państwach imperium habsburskiego coraz bardziej oddalają kształtowane rozwiązania od ich austriackiego pierwowzoru, jednak absolutnie nie zrywają z nim. Tendencję tę łatwo wytłumaczyć wolą unowocześnienia procedury i stworzenia $\mathrm{z}$ niej sprawnego narzędzia wykonywania

11 Magyar Közlöny nr 203/2004.

12 Tło zachodzących przeobrażeń przedstawił szerzej I. Balázs, Eastern Europe in Transition, the Case of Hungary, „Acta Juridica Hungarica” 2012, no. 2, s. 115 i n. 
administracji, a niezależnie od tego - potrzebą pełnego urzeczywistnienia standardów wynikających z prawa unijnego, rekomendacji Komitetu Ministrów Rady Europy czy ogólnie: wartości stanowiących fundamenty europejskiej kultury prawnej. Analiza wyników tego, co można określić mianem rekodyfikacji, prowadzi do wniosku, że postępowanie typu jurysdykcyjnego (tryb orzekania w sprawach indywidualnych w formie decyzji administracyjnej) staje się powoli tylko jednym $z$ elementów szerszego zbioru procedur unormowanych przez ustawę, powiązanych ze sobą treściowo i funkcjonalnie. Istotnych przeobrażeń doznają zarazem formy tego postępowania i jego główne instytucje, z legitymacją procesową, aktem kończącym postępowanie oraz trybami zaskarżenia (kontroli) działań administracji włącznie. Wydawanie decyzji w sprawach indywidualnych, bądź korzystanie z alternatywnego wobec niej środka - umowy administracyjnej (publicznoprawnej), nie jest już jedynym przejawem aktywności organów administracyjnych poddanym reglamentacji procesowej. Wyraźnie ujawnia się dążenie do rozciągnięcia tej reglamentacji także na działalność polegającą na wydawaniu aktów generalnych o różnym charakterze i podejmowaniu rozmaitych czynności faktycznych, takich jak prowadzenie rejestrów, sporządzanie zaświadczeń albo dokonywanie kontroli wykonania decyzji. Mocno ugruntowaną zasadą jest też zamieszczanie w kodeksach, ze względów praktycznych, przepisów dotyczących egzekucji aktów administracji, a niekiedy również aktów jurysdykcji sądowej w sprawach administracyjnych. Unormowania stricte procesowe zaczynają też być uzupełniane innego rodzaju regulacjami, coraz śmielej wkraczającymi w sferę prawa ustrojowego i materialnego. Zmienia się wobec tego nie tylko struktura, ale i rola aktów rangi kodeksowej. W tej sytuacji wydatnemu rozszerzeniu ulega przedmiot zawartych w nich postanowień. Dążenie do objęcia ramami jednej ustawy tak złożonej materii narzuca - co oczywiste - konieczność stosowania bardziej wysublimowanych niż dotychczas technik prawotwórstwa, w tym operowania klauzulami generalnymi, odesłaniami, przepisami o wyłączeniu stosowania pewnych grup unormowań i zastrzeżeniami, pozwalającymi na zachowanie „systemowego” charakteru danej regulacji ${ }^{13}$.

Szerszego omówienia wymaga - jak sądzę - kwestia włączenia do analizowanych uregulowań rangi kodeksowej przepisów dotyczących materii postępowania egzekucyjnego w administracji, która tradycyjnie nie tylko w Austrii, ale i w Polsce, jest przedmiotem odrębnych ustaw. Idea takiego unormowania zrodziła się w czasach sprzed transformacji ustrojowej z przełomu XX i XXI w. Można przypuszczać, że jej rozwinięcie w ustawodawstwie państw sukcesji habsburskiej jest efektem zgromadzonych wcześniej doświadczeń. W odróżnieniu od obszernego, nazbyt szczegółowego i zawiłego uregulowania wprowadzonego przez polską ustawę z 17 czerwca 1966 r. o postępowaniu egzekucyjnym w administracji ${ }^{14}$, jego

13 Z. Kmieciak, Idea kodyfikacji postępowania administracyjnego z perspektywy państw postsocjalistycznych, „Państwo i Prawo” 2017, nr 9, s. 33-34.

14 Tekst jednolity - Dziennik Ustaw 2019, poz. 1438. 
odpowiedniki w systemach czeskim i słowackim, węgierskim, bułgarskim czy państw byłej Jugosławii odznaczają się zwięzłością i abstrakcyjnym ujęciem tworzonych klauzul.

Przepisy o postępowaniu egzekucyjnym w administracji zawarte w aktach nowej kodyfikacji liczą od kilku do kilkudziesięciu podstawowych jednostek redakcyjnych o różnych rozmiarach (artykułów, oznaczanych też jako paragrafy albo sekcje). Przykładowo ustawa chorwacka z 27 marca 2009 r. o ogólnym postępowaniu administracyjnym (zakon o općem upravnom postupku ${ }^{15}$ zawiera jedynie 16 artykułów odnoszących się do egzekucji obowiązków o charakterze pieniężnym i niepieniężnym. Przepisy te - odmiennie niż w Polsce - są nie tyle szczegółowymi instrukcjami dla urzędników co ogólnymi klauzulami określającymi sposób działania w toku egzekucji. Niewiele więcej artykułów w tym przedmiocie liczy ustawa bośniacka z 25 czerwca 2002 r. o postępowaniu administracyjnym (zakon o upravnom postupku $)^{16}$. Najobszerniejsze $\mathrm{z}$ unormowań o postępowaniu egzekucyjnym w państwach regionu bałkańskiego - to, które znalazło się w obowiązującym od 12 lipca 2006 r. bułgarskim kodeksie postępowania administracyjnego ${ }^{17}$, skonstruowano przy użyciu tylko 34 - co prawda składających się z wielu postanowień - artykułów. Charakter ustanawianych klauzul doskonale oddaje treść art. 145 ustawy chorwackiej, wyrażającego zasadę proporcjonalności. Zgodnie z tym przepisem, egzekucja powinna być prowadzona tak, aby zastosowane środki były najmniej uciążliwe dla zobowiązanego (most lenient on the enforcement debtor), zapewniając jednocześnie osiągnięcie celu egzekucji. Trudno nie postawić pytania: czy tak sformułowany przepis stwarza wystarczające umocowanie do ferowania ocen przez urzędnika, który przywykł do dokładnego wskazania mu przez przepisy prawa co ma czynić (operowania ścisłymi, wymiernymi kryteriami, przesądzającymi o wyborze wariantu zachowania).

Słabością opisywanego wariantu regulacji, uznawanego za racjonalny i zgodny z założeniami dokonywanych współcześnie zabiegów kodyfikacyjnych, jest konieczność stosowania przez legislatywę technik pozwalających zachować jego kompletność oraz określić jasno związki między wprowadzonym unormowaniem i innymi reżimami egzekucji. Ustawodawca bułgarski rozstrzygnął ten dylemat, wskazując, że wyznaczona przepisami kodeksu procedura ma zastosowanie do tytułów wykonawczych dotyczących indywidualnych lub generalnych aktów administracyjnych, wyroków, postanowień i zarządzeń sądów administracyjnych oraz ugód zawartych przed organami administracji albo sądami ${ }^{18}$.

Jak zostało już wspomniane, przepisy o postępowaniu jurysdykcyjnym są nadal najważniejszym, ale nie jedynym składnikiem obowiązujących w państwach

15 Narodne novine $\mathrm{nr}$ 47/2009.

16 Službeni novine Federacije BH nr 29/2002.

17 Vestnik nr 30/2006.

18 Z. Kmieciak, Idea kodyfikacji..., s. 39-40. 
sukcesji habsburskiej unormowań kodeksowych. Założenia i instytucje tego postępowania doznały, w rezultacie podejmowanych w ostatnich dziesięcioleciach inicjatyw rekodyfikacyjnych, istotnego przeobrażenia. Rozstrzyganie w nim o sprawach indywidualnych następuje w różnych trybach: decyzyjnym, ugodowym lub umownym, sformalizowanym, uproszczonym albo automatycznym, głównym bądź nadzwyczajnym, przy zastosowaniu mediacji lub poza nią. Działanie to zawsze jednak podlega rygorom wyprowadzanym z kodeksowych zasad ogólnych. Powszechną praktyką jest wyodrębnianie tych zasad w wyraźnie oznaczonej części ustawy i nadawanie im nazw obrazujących chronioną wartość, znajdującą najczęściej umocowanie konstytucyjne. Korespondują one bądź nawet pokrywają się z europejskimi standardami dobrej administracji, będącymi z kolei refleksem idei rzetelnego (sprawiedliwego) procesu ${ }^{19}$. Stosowanie niektórych $\mathrm{z}$ tych zasad rozciąga się na wszystkie rodzaje aktywności administracji, a nie tylko działalność orzeczniczą.

Dostrzegany ogólnie fakt „wypierania” unormowań kodeksowych przez przepisy szczególne, wprowadzające określone odrębności proceduralne, kwalifikowany jako zawoalowana forma dekodyfikacji postępowania administracyjnego przez stosowanie techniki bypasses, skłania do uważnego przyjrzenia się próbom powstrzymania tego zjawiska ${ }^{20}$. Ciekawym przykładem tej kategorii działań legislatywy jest sformułowanie w art. 2 ustawy bośniackiej ogólnej zasady, w myśl której w określonych sferach administracji tylko wyjątkowo dopuszczalne jest regulowanie jednostkowych zagadnień proceduralnych przez inne ustawy w sposób odmienny od przyjętego w tym akcie. Jednakże nawet wtedy unormowania uchodzące za lex specialis w stosunku do ustawy o postępowaniu administracyjnym nie moga pozostawać w sprzeczności z jej zasadami (may not be in contradiction with the principles of this law). Podobny przepis zamieszczono w art. 3 serbskiej ustawy z 29 lutego 2016 r. o ogólnym postępowaniu administracyjnym (zakon o opštem upravnom postupku ${ }^{21}$. Nakaz zgodności uregulowań szczególnych z określonymi w niej zasadami uzupełniono zastrzeżeniem, że wprowadzenie odrębnych przepisów nie może „obniżać poziomu ochrony praw i interesów prawnych stron gwarantowanej niniejszą ustawą". W ustawie bośniackiej nakazano także subsydiarne stosowanie jej przepisów w tych sprawach, które podlegają załatwieniu według odrębnego reżimu procesowego, o ile dana kwestia nie została nim objęta (art. 3).

19 Co do koncepcji rzetelnego procesu administracyjnego (a theory of administrative due process) zob. K. Werhan, Principles of Administrative Law, St. Paul 2008, s. 107-157 oraz G. della Cananea, Due Process..., s. 139 i n.

20 Z prac poświęconych tej problematyce zob. w szczególności Li Zhang, China oraz T. Barkhuysen, W. den Ouden, Y.E. Schuurmans, Netherlands - obydwa opracowania zamieszczono w zbiorze: Codification of Administrative..., odpowiednio s. 102 i 266-267; z polskich publikacji - J. Zimmermann, Aksjomaty prawa administracyjnego, Warszawa 2013, s. 188 oraz Z. Kmieciak, Zarys teorii postępowania administracyjnego, Warszawa 2014, s. 69 i n.

21 Službeni glasnik RS nr 18/2016. 
Przepisy rozpatrywanego zbioru ustaw definiują stronę postępowania jurysdykcyjnego w sposób odpowiadający wzorom austriackim, traktując jako kluczowe elementy tej instytucji pojęcia praw, wolności, obowiązków oraz interesów prawnych. Niektóre z nich przyznają ochronę, która w pewnym stopniu wyłamuje się z utrwalonego wcześniej schematu. Stwierdzenie to można odnieść do stron w znaczeniu formalnym w rozumieniu przepisów $\$ 15$ ust. 3 nieobowiązującej już ustawy węgierskiej z 2004 r. lub grup osób o wspólnym interesie (groups of persons associated by a common interest), powołujących się na swoje prawa i obowiązki, które wymagają rozstrzygnięcia w postępowaniu administracyjnym - stanowi o nich art. 4 ust. 2 ustawy chorwackiej.

Za alternatywę dla decyzji jako aktu załatwiającego sprawę indywidualną uznaje się - co do zasady - ugodę zawieraną pomiędzy stronami postępowania oraz umowę strony z organem. Na charakter ostatniego z wyróżnionych aktów wskazują przymiotniki: „administracyjna” albo „publicznoprawna”. Operowanie tym środkiem wypełniania zadań przez administrację podlega pewnym ograniczeniom. Według ustawy chorwackiej umowa nie może pozostawać w sprzeczności z dyspozycjami decyzji i bezwzględnie obowiązujących przepisów prawa, jak też interesem publicznym, bądź powodować uszczerbku dla osób trzecich. Jeśli rodziłaby ona skutki prawne dla tych osób, wymagana jest - dla zachowania jej ważności - pisemna zgoda tych osób (art. 150 ust. 3). Ustawa czeska z 24 czerwca 2004 r. o postępowaniu administracyjnym (správní řád) 22 stanowi ogólnie, że umowa nie może być sprzeczna $\mathrm{z}$ prawem lub być zawarta w celu jego obejścia. Musi być ponadto zgodna z interesem społecznym ( $\$ 159$ ust. 2). Realizująca bardziej restrykcyjną koncepcję ustawa chorwacka jako wstępny warunek posłużenia się formą umowy administracyjnej wskazała udzielenie na to stosownego zezwolenia przez przepisy prawa (art. 150 ust. 1 in fine). Podobne zastrzeżenie znalazło się w ustawie węgierskiej z 2004 r. (\$ 76 ust. 1). Warto dodać, że w celu ułatwienia korzystania z form konsensualnych w postępowaniu administracyjnym, aktem tym wprowadzono instytucję urzędnika łącznikowego (hatósági közvetítö - ang. liaison officer). Organy administracji upoważniono do zatrudnienia na tym stanowisku osób o odpowiednich kwalifikacjach, aby ułatwić rozwiązywanie sporów pomiędzy nimi i stronami postępowania (spory wertykalne) oraz pomiędzy stronami o przeciwstawnych interesach (spory horyzontalne). Urzędnika łącznikowego uczyniono odpowiedzialnym za przekazywanie rzetelnych i aktualnych informacji w zrozumiałym dla adresatów języku, dotyczących przedmiotu postępowania i jego przewidywanych skutków oraz wszelkich środków koniecznych do zapobieżenia niekorzystnym dla stron skutkom. Do jego zadań ustawa zaliczyła ponadto prowadzenie mediacji w każdym z wyodrębnionych układów (wertykalnym i horyzontalnym), w intencji znalezienia rozwiązania pozwalającego osiągnąć cel postępowania, „z korzyścią" dla wszystkich zainteresowanych stron.

22 Sbírka zákonů ČR nr 500/2004. 
Za inną osobliwość wskazanej ustawy węgierskiej można uznać określony jej przepisami tryb monitorowania przestrzegania prawa i realizacji uprawnień oraz obowiązków wynikających z decyzji posiadających przymiot wykonalności. Akt ten dopuścił przeprowadzanie, z urzędu lub na wniosek, kontroli administracyjnych (okresowych, stałych oraz zwykłych), jeżeli tylko nie wykluczają tego ustawy albo rozporządzenia rządowe ${ }^{23}$. W kolejnej kodyfikacji węgierskiej dokonanej ustawą z 2016 r. nr CL - Kodeks ogólnego postępowania administracyjnego (törveny az általános közigazgatási rendtartásról) ${ }^{24}$ problematyka ta stała się przedmiotem przepisów $\$ 98-102$ o audycie administracyjnym (administrative audit). Nie jest chyba rzeczą przypadku włączenie postanowień o kontroli administracyjnej do projektu Modelu kodeksu postępowania administracyjnego Unii Europejskiej, opracowanego przez powołaną w 2009 r. grupę ReNEUAL (Księga III - Wydawanie decyzji w sprawach indywidualnych). Prowadzenie kontroli dostarcza przecież danych pozwalających na wtórną weryfikację zgromadzonego $\mathrm{w}$ rozstrzygniętej już sprawie materiału dowodowego, w szczególności rzetelności oświadczeń złożonych przez stronę, bądź informacji niezbędnych do oceny wywiązywania się przez nią z obowiązków wynikających z określonego aktu (decyzji, ugody, umowy administracyjnej), np. respektowania warunków udzielonego pozwolenia. Kontrola może też być impulsem do wszczęcia, w nowej sprawie, postępowania przed organem administracji publicznej lub innym podmiotem. Przez wzgląd na tę zależność (związek czynności kontrolnych z uruchamianiem odpowiednich sankcji) celowość regulowania w ustawach o postępowaniu administracyjnym czynności kontrolnych nie powinna być kwestionowana.

Za bezdyskusyjny uchodzi obecnie pogląd, że przepisy o postępowaniu jurysdykcyjnym mają nie tylko tworzyć odpowiednie gwarancje ochrony praw i interesów jednostki, ale i zapewniać efektywność podejmowanych przez organy administracyjne działań ${ }^{25}$. Podporządkowane realizacji tego postulatu zmiany ustawodawstwa muszą wobec tego uwzględniać idee i założenia „dobrego zarządzania”, wymagania rachunku ekonomicznego, uciążliwości związane z partycypacją w postępowaniu różnych podmiotów czy nakład czasu przeznaczonego na finalne załatwienie sprawy, w tym rozstrzygnięcie powstających na tym tle sporów sądo$w_{y c h}{ }^{26}$. Rodzi to konieczność rezygnacji w określonych sferach administrowania

23 Szerzej Z. Kmieciak, Węgierska ustawa o ogólnych zasadach postępowania w sprawach administracyjnych - koegzystencja dwóch wizji porządku prawnego?, „Państwo i Prawo” 2017, nr 4, s. 31-32.

24 Maygar Közlöny nr 200/2016.

25 Zob. przykładowo A.R. Brewer-Carias, Principios generales del procedimiento administrativo: hacia un estándar continental, [w:] Procedimiento y justicia administrativa en América Latina, red. C. Steiner, Mexico 2009, s. 183-184 oraz Z. Kmieciak, Pragmatyzm postępowania administracyjnego, [w:] Fenomen prawa administracyjnego. Księga Jubileuszowa Profesora Jana Zimmermanna, red. W. Jakimowicz, M. Krawczyk, I. Niżnik-Dobosz, Warszawa 2019, s. 498 i n.

26 Szerzej I. Koprić, Administrative Technology and General Administrative Procedure: Challenges and Changes in South-Eastern Europe, „Hrvatska i Komparativna Javna Uprawa” 2010, no. 1, s. 447-449. 
z nazbyt sformalizowanych, bliskich modelowi procedury sądowej, trybów rozpoznawania spraw indywidualnych i zastępowania ich trybami uproszczonymi, a niezależnie od tego - modyfikacji tradycyjnych instytucji prawa procesowego, zwłaszcza w obrębie kontroli aktów podejmowanych przez administrację.

Odejściem od koncepcji szczegółowej reglamentacji czynności postępowania administracyjnego i stałego zwiększania przez to stopnia jego rygoryzmu są rozwiązania przyjęte m.in. w ustawie chorwackiej, kształtujące dwa podstawowe reżimy orzekania w sprawach indywidualnych: pełny (standardowy) i uproszczony. Zastosowanie uproszczonego trybu wydania decyzji (art. 48-50) wchodzi w grę wtedy, gdy stan faktyczny sprawy może być zrekonstruowany już na etapie wszczęcia postępowania, bez potrzeby uruchamiania czynności wyjaśniających i wysłuchania strony. Jest on dostępny wyłącznie $\mathrm{w}$ sprawach wyliczonych przez ustawy, o ile nie uczestniczą w nich strony o spornych interesach. Regulację w tym przedmiocie uzupełniają przepisy o terminie załatwienia sprawy oraz skutkach prawnych jego niedotrzymania przez organ administracji (art. 101-102). Jeżeli odrębne przepisy nie stanowią inaczej, wydanie decyzji w trybie uproszczonym i doręczenie jej adresatowi powinno nastąpić niezwłocznie, nie później jednak niż w terminie $30 \mathrm{dni}$ od dnia złożenia wniosku. W przypadkach wskazanych przez unormowania szczególne, niedochowanie ustawowego terminu załatwienia sprawy uważa się za równoznaczne z uwzględnieniem złożonego przez stronę w należyty sposób wniosku (milczące załatwienie sprawy). W piśmiennictwie sygnalizuje się, że ustanowienie tych konstrukcji zapewniło wysoce efektywną ochronę praw stron, „choć tylko w sferach uznanych przez legislatywę za odpowiednie" (but only in areas determined as appropriate by the legislature $)^{27}$. Podobny reżim stworzyły przepisy $₫ 39-43$ węgierskiej ustawy z 2016 r. Obok trybów pełnego i uproszczonego rozpatrzenia wniosku (a full and a summary procedure), wyróżniły one dodatkowo procedurę zautomatyzowanego podejmowania decyzji (an automatic decision-making procedure). Zgodnie z $\$ 50$ ustawy, w razie uruchomienia ostatniego $\mathrm{z}$ trybów sprawa załatwiana jest $\mathrm{w}$ terminie 24 godzin ( $\mathrm{w}$ „pełnym” postępowaniu w terminie nie dłuższym niż $60 \mathrm{dni}$, zaś w postępowaniu uproszczonym - w terminie $8 \mathrm{dni}$ ).

Cechy procedury uproszczonej wykazują też rozwiązania przyjęte przez ustawę czeską. Za takie można uznać „postępowanie na miejscu” (ř́zení na místě) uregulowane przez przepisy rozproszone $\mathrm{w}$ różnych częściach tego aktu ${ }^{28}$. Zgodnie z $\$ 143$ ust. 2 przesłanką nałożenia obowiązku „na miejscu” jest ustalenie faktów sprawy. Decyzja jest ogłaszana ustnie, jednakże powinna ona być następnie doręczona $\mathrm{w}$ formie pisemnej bez zbędnej zwłoki. Jeżeli odrębne ustawy nie stanowią

27 Tak D. Đerđa, Republic of Croatia, [w:] Codification of Administrative..., s. 118.

28 Zob. M. Szubiakowski, Postępowanie uproszczone - nowa instytucja polskiej procedury administracyjnej, [w:] Idea kodyfikacji w nauce prawa administracyjnego procesowego. Księga pamiątkowa Profesora Janusza Borkowskiego, red. Z. Kmieciak, W. Chróścielewski, Warszawa 2018, s. 326-327. 
inaczej, odwołanie od ustnej decyzji nie wywołuje skutku suspensywnego. Stosownie do $\$ 67$ ust. 3, taką decyzję organ administracji potwierdza pisemnie „na miejscu", jeżeli zażąda tego uczestnik postępowania.

W Polsce przepisy o trybie uproszczonym załatwienia sprawy włączono do kodeksu postępowania administracyjnego w rezultacie zasadniczej zmiany tego aktu w 2017 r. Licząc się z ryzykiem naruszenia interesów stron, w art. 163d kodeksu określono okoliczności uzasadniające przeniesienie załatwienia sprawy z trybu uproszczonego do zwykłego ${ }^{29}$.

Różne odmiany procedury uproszczonej są dobrze znane ustawodawstwu innych państw, w tym systemom common law. W Stanach Zjednoczonych, pod rządem ustawy federalnej z 1946 r. o postępowaniu administracyjnym (the Administrative Procedure Act), występują one pod nazwą „skrótów proceduralnych" (procedural shortcuts): urzędowego powiadomienia o materialnych faktach sprawy, zastępującego formalne postępowanie dowodowe (official notice of material facts) oraz trybu „przyspieszonego orzekania” (a summary judgment procedu$r e)^{30}$. Korzystanie $\mathrm{z}$ tych form postępowania nie jest - o czym nie wolno zapominać - zagadnieniem wolnym od kontrowersji. Nie brak opinii, że operowanie pierwszą z nich może godzić w wyprowadzane z konstytucyjnej zasady due process prawo strony do "uczciwego wysłuchania administracyjnego" (right to a fair administrative hearing). W orzecznictwie sądowym wypracowano w związku z tym kryteria, które musi spełniać dane działanie, aby uznać je za zgodne $\mathrm{z}$ prawem. Precyzują one wyrażoną w ustawie o postępowaniu administracyjnym regułę, że w sytuacji, gdy decyzja agencji opiera się na ustaleniach przedstawionych w urzędowym powiadomieniu, należy zapewnić stronie możliwość ich zakwestionowania (zgłoszenia zdania przeciwnego). Zgodnie z ugruntowaną linią orzecznictwa sądowego, dostępny agencji materiał powinien być zawsze szczegółowo określony, z podaniem konkretnego źródła uzyskanych informacji. Strona musi też mieć rzeczywistą, a nie tylko czysto teoretyczną sposobność zweryfikowania zaprezentowanych ustaleń, jak również wyłożenia swoich argumentów ${ }^{31}$. Wyliczone zasady case law nie odbiegają od standardu, do którego przywykliśmy w systemach europejskich.

Nakaz efektywności działania, ujęty wprost w zasadach ogólnych ustaw o postępowaniu administracyjnym państw sukcesji habsburskiej, raczej trudno pogodzić z funkcjonowaniem rozbudowanego ponad miarę systemu weryfikacji aktów wydawanych przez organy administracji, przeprowadzanej w trybie głównym i w trybach nadzwyczajnych. Nie powinno przeto dziwić widoczne

29 Szerzej Z. Kmieciak, [w:] Kodeks postępowania administracyjnego. Komentarz, red. Z. Kmieciak, W. Chróścielewski, Warszawa 2019, s. 913-914.

30 Zob. E. Gellhorn, R.M. Levin, Administrative Law and Procedure in a Nutshell, St. Paul 2006, s. 298 i n. oraz D. Custos, United States..., s. 387-388.

31 E. Gelhorn, R.M. Levin, Administrative Law..., s. 303-304. 
w różnych częściach Europy dążenie do racjonalizacji mechanizmów ochrony praw jednostki i poszukiwania rozwiązań adekwatnych do warunków, w jakich współczesna administracja wykonuje powierzone jej zadania. Wyrazem realizacji tego założenia jest zerwanie $\mathrm{z}$ wizją dewolutywnego środka zaskarżenia decyzji jako jedynej formy odwołania administracyjnego. Nie brak oczywiście głosów, że odwołanie typu niedewolutywnego, kierowane do tego samego organu, który podjął kwestionowane rozstrzygnięcie, jest środkiem ułomnym, gdyż jego wniesienie inicjuje "quasi-dwuszczeblowe postępowanie” („quasi-two-tier proceeding"), pozbawione takich gwarancji obiektywizmu orzekania, jakie posiada „rzeczywiste” postępowanie dwuinstancyjne ${ }^{32}$. Okazuje się jednak, że legislatywa i - w równym stopniu - praktyka znalazły sposób na zniwelowanie tej niedogodności, przyjmując zasadę wewnętrznej dewolucji kompetencji. Wprowadził ją np. w stosunku do środka zaskarżenia decyzji nazwanego sprzeciwem art. 122 ustawy chorwackiej. Przepis ten zastrzegł, że właściwym do rozpoznania odwołania niedewolutywnego jest kierownik organu. Podobne rozwiązanie (rozklad) jest znane prawu słowackiemu. Zostało ono ukształtowane przez $\$ 61$ czechosłowackiej ustawy nr 71 z 29 czerwca 1967 r. o postępowaniu administracyjnym - zakon o správnom konani (správny poriadok) ${ }^{33}$. Kierownik organu centralnego rozstrzyga $w$ trybie tego przepisu sprawę po zapoznaniu się z opinią specjalnej komisji jako organu doradczego. W innym z państw sukcesji habsburskiej, a mianowicie na Węgrzech, Trybunał Konstytucyjny jeszcze w latach dziewięćdziesiątych XX w. przyznał, że prawo do odwołania przybiera różne formy. Uzupełniając tę tezę, Trybunał stwierdził, że doznaje ono urzeczywistnienia w wyniku rozpatrzenia sprawy przez inny organ niż ten, który wydał decyzję, bądź „na forum wyższej instancji przez ten sam organ” ${ }^{34}$.

Ciekawym zjawiskiem jest również rozszerzanie zakresu kontroli realizowanej przez wniesienie środka zaskarżenia w trybie administracyjnym. W myśl przepisów zawartych w ustawach nowszej generacji taka weryfikacja obejmuje także inne czynności niż wydawanie aktów administracyjnych (decyzji indywidualnych). Ilustracją tego spostrzeżenia jest instytucja sprzeciwu (prigovor) w rozumieniu art. 147-150 ustawy serbskiej. Przedmiotem odrębnej regulacji stało się w niej prawo do odwołania od decyzji administracyjnej (pravo na žalbu).

32 Zob. V. Cucić, Administrative Appeal in Serbian Law, „Transylvanian Review of Administrative Sciences" 2011, nr 32E, s. 60-61.

33 Zbierka zákonov Československej socialistickej republiky nr 71/1967.

34 Cyt. za A. Paulovics, Guarantees of the Legality of Administration and Administrative Procedure in Hungary, „DANUBE/Law and Economics Review” 2011, nr 2, s. 48. Za odosobnioną trzeba w związku z tym uznać koncepcję, według której odwołanie administracyjne zawsze wywiera skutek dewolutywny - szerzej o tak rozumianym środku P. Kovač, Effective Adjudication through Administrative Appeals in Slovenia, „Utrecht Law Review” 2013, vol. 9, issue 3, s. 43. 


\section{Pytania o formułę kodyfikacji postępowania administracyjnego}

W ocenie jednego z najbardziej znanych polskich teoretyków,

Na płaszczyźnie porównawczej można wyciągnąć naukę [...], że kraj mający skodyfikowaną procedurę administracyjną nie zdecyduje się nigdy potem wrócić - z jakichkolwiek racji - do dawnego systemu unormowań fragmentarycznych, prawdziwej „wolności procesowej” administracji publicznej ${ }^{35}$.

Zmiany legislacyjne, jeśli już je wprowadzamy, idą zatem zwykle w jedną stronę: tworzenia coraz bardziej rozbudowanych, szczegółowych, zawiłych i skomplikowanych uregulowań w nadziei, że okażą się one efektywne ${ }^{36}$. Ruchy przeciwne, zwłaszcza w państwach o utrwalonej tradycji kodyfikacyjnej, należą do zupełnej rzadkości. Czy jednak właśnie ten sposób działania (rezygnacja z kazuistyki na rzecz bardziej ogólnych klauzul, wyznaczających dostatecznie duży zakres luzu decyzyjnego dla organów administracji stosujących prawo i sądów) nie powinien być reakcją na obserwowane powszechnie niepowodzenia zabiegów podejmowanych przez legislatywę? Naturalne skądinąd dążenie do ulepszania litery prawa nie może przecież odbywać się kosztem jego przejrzystości i użyteczności. W tym kontekście warto rozważyć inną kwestię: jak długo przetrwają rozwiązania będące wynikiem rekodyfikacji postępowania administracyjnego w systemach prawnych, w których przyjęto przed laty wzory austriackie? Czy legislatywa będzie zdolna oprzeć się pokusom łatwych, dyktowanych potrzebą chwili, zmian unormowań ustawowych? Wyłania się ponadto pytanie, czy kodeksy, które niegdyś regulowały tylko tryb orzekania w sprawach indywidualnych, nie stają się współcześnie „kodeksami działalności administracyjnej” lub nawet „kodeksami administracji i jej kontroli”. Przykładem drugiego rodzaju kodyfikacji jest ustawa niderlandzka z 1994 r., ustawa gruzińska z 1999 r. i ustawa bułgarska z 2006 r. Być może właśnie analizowane zabiegi legislacyjne są pierwszym etapem na drodze kodyfikacji części ogólnej prawa administracyjnego ${ }^{37}$. Niestety, podjęte

35 G. Langrod, Genése et lignes directrices de la réforme de la procédure administrative non contentieuse en Pologne, „Revue Internationale des Sciences Administratives” 1960, nr 4, s. 399. Por. także uwagi dotyczące „życia bez GAPA” (general administrative procedure acts) - J.-B. Auby, General Report, [w:] Codification of Administrative..., s. 27-28.

36 Por. chociażby rozważania na temat doświadczeń słoweńskich - P. Kovač, The Requirements and Limits of the Codification of Administrative Procedure in Slovenia According to European Trends, „Review of Central and East European Law” 2016, vol. 41, s. 448-449. Wynika z nich, że regulacja procesowa w sprawach administracyjnych jest nazbyt sformalizowana i szczegółowa.

37 Realizację tej idei w jednym z państw Ameryki Łacińskiej, a mianowicie w Kostaryce, w postaci aktu: Ley General de la Administración Pública, omawia A.R. Brewer-Carias, Principios generales..., s. 165. 
w Polsce kilkakrotnie próby uchwalenia ustawy w tym przedmiocie zakończyły się niepowodzeniem ${ }^{38}$.

Upadek imperium habsburskiego w $1918 \mathrm{r}$. obalił pielęgnowany w nim mit „wspólnoty narodów”39. Nie podważył jednak dorobku myśli prawnej z XIX i początków XX w. wykorzystanego w toku kształtowaniu systemów postępowania administracyjnego w państwach sukcesji habsburskiej. Dorobek ten stał się częścią spuścizny kulturowej i czynnikiem, który na stałe przeniknął do krajowych porządków prawnych. Jak stwierdza wytrawny badacz historii Habsburgów, nawet gdy ich monarchia formalnie przestała istnieć, jej dokonania i osiągnięcia „trwały w umysłach ludów". Prominentni politycy państw sukcesyjnych przyjmowali znane im sprzed pierwszej wojny światowej prawa, praktyki i instytucje, „choć jednocześnie głośno odrzucali dziedzictwo Austro-Węgier jako nieprzystające do demokracji i samostanowienia narodów" ${ }^{40}$.

Prof. dr hab. Zbigniew Kmieciak jest kierownikiem Katedry Postępowania Administracyjnego na Wydziale Prawa i Administracji Uniwersytetu Łódzkiego, sędzią Naczelnego Sądu Administracyjnego w stanie spoczynku, autorem około 300 publikacji naukowych oraz wielu opinii przygotowanych na potrzeby procesu legislacyjnego i praktyki. Przewodniczył zespołowi ekspertów do spraw reformy prawa o postępowaniu administracyjnym, który działał w latach 2012-2016. Sporządzony przez zespół raport został wykorzystany w toku prac, których zwieńczeniem stała się dokonana w roku 2017 zasadnicza nowelizacja Kodeksu postępowania administracyjnego.

38 Zob. General Provisions of Administrative Law - Grounds for the Draft of a Bill, [w:] Prawo do dobrej administracji, Biuletyn RPO. Materiały, nr 60, Warszawa 2008, s. 215 i n.

39 Szerzej P.M. Judson, The Habsburg Empire. A New History, Cambridge (Massachusetts) -London (England) 2016, s. 15-19, 88-89 oraz 447 i n.

40 P.M. Judson, The Habsburg Empire..., s. 23. 


\section{Chapter II}

\section{Administrative Procedure in Austria - from the Monarchy to the Republic}

Laura Rathmanner, Mag., University Assistant (prae doc)

University of Vienna, Law Faculty, Department of Legal Philosophy

laura.rosemarie.rathmanner@univie.ac.at

iD https://orcid.org/0000-0002-1630-4135

\section{Administrative Procedure from 1867 to 1914}

The historical development of the Austro-Hungarian Monarchy's and Austria's administrative law before the codification of the administrative procedure in 1925 can be divided into three phases. At the beginning, administration was carried out within the estate system. Initially, the estates and/or regional sovereigns also needed legal titles to safeguard general interests towards the individual subject. With the recognition of the general title ius politae as sovereign right, these special titles came to be supplanted; the legal protection of the citizen's acquired rights was guaranteed by the courts of the empire and the jurisdiction of the sovereigns. ${ }^{1}$ Antecedents of procedural laws - long before the recognition of subjective rights in the field of public law - can be seen in official instructions (Amtsinstruktionen and Amtsanordnungen) addressed to the officials, which contained requirements for general official duties, in particular the obligation to exercise their functions impartially. ${ }^{2}$ In the age of monarchical absolutism, administration entered a new stage: the influence of the estates was pushed back by the sovereign, who established the entire (central) administration (Policey) at his discretion. ${ }^{3}$ The administrative apparatus was expanded and a "bureaucratic state" (Beamtenstaat)

1 R. Herrnritt, Österreichisches Verwaltungsrecht. Ein Grundriß der Rechtstheorie und Gesetzgebung der inneren Verwaltung, Tübingen 1925, pp. 8-9.

2 E.C. Hellbling, Österreichische Verfassungs- und Verwaltungsgeschichte, Wien 1956, p. 228.

3 R. Herrnritt, Österreichisches Verwaltungsrecht..., p. 9. The creation of the "police" in a modern sense as separate institution responsible for public safety later took place under Joseph II - T. Olechowski, Rechtsgeschichte. Einführung in die historischen Grundlagen des Rechts, Wien 2016, p. 189. 
implemented. ${ }^{4}$ The estates' remaining influence in the judiciary led to the monarch's attempt at gaining unlimited influence through the detachment of administrative matters. In terms of organisation, this showdown was reflected in reforms and the restructuring of the administrative apparatus as it took place under Maria Theresia and also during the (brief) period of neo-absolutism (from 1851). Regarding the system of judicial review, the practice of the so-called Machtsprüche, also referred to as Kabinettsjustiz, i.e. the monarch's claim to a right to intervene in supreme court decisions or to revise them, was particularly controversial. The advancement of constitutionalism led to the recognition of the primacy of legislation over enforcement in general, the latter including the judiciary as well as the administration. Administrative rules no longer provided only guidelines for the authorities, but could also be the source of subjective rights of individuals vis-à-vis the state. ${ }^{5}$ The definite turn to constitutionalism was marked by the December Constitution of 1867 and led to the phase of administration according to the rule of law, where the newly created jurisdiction in the area of public law was competent to guarantee the administration's compliance with subjective rights and procedural rules if not to control the "free discretion" (freies Ermessen) of the administrative authorities. However, in spite of ongoing reform efforts, the creation of a uniform, systematic administrative procedure was only possible after the end of the monarchy.

In 1867, in the course of liberalisation, the judiciary was finally separated from administration down to the lowest instance. ${ }^{6}$ According to Article 14 of one of the fundamental laws constructing the December constitution - Judiciary Act (Staatsgrundgesetz über die richterliche Gewalt), the administration of justice had to be separated from general administration in all instances; the corresponding reorganisation of the public authorities was implemented in May 1868. Oversight over the administration was not put in the hands of the ordinary courts, but - as in most German states - transferred to a separate jurisdiction, consisting of the public-law courts of justice, the Imperial Court (Reichsgericht) ${ }^{7}$ and the Supreme Administrative Court (Verwaltungsgerichtshof). ${ }^{8}$

Another fundamental law of the December Constitution formed the legal basis for the establishment of the Imperial Court - Act on Establishing the Imperial Court (Staatsgrundgesetz über eines Einsetzung eines Reichsgerichts). This Act, according to its Article 6, was implemented by the Statute of 18 April 1869,

4 T. Olechowski, Rechtsgeschichte..., pp. 188-189.

5 R. Herrnritt, Österreichisches Verwaltungsrecht..., p. 10.

6 E.C. Hellbling, Die Landesverwaltung in Cisleithanien, [in:] Die Habsburgermonarchie 18481918, Red. A. Wandruszka, P. Urbanitsch, Wien 2003, p. 217.

7 The English translation of the German word "Reichsgercht" follows the one presented by C. Grabenwarter, The Austrian Constitutional Court, [in:] The Max Planc Handbooks in European Public Law, vol. III, Constitutional Adjudication. Institutions, eds. A. von Bogdandy, P.M. Huber, C. Grabenwarter, Oxford 2020, p. 23 (the editor's note).

8 R. Herrnritt, Österreichisches Verwaltungsrecht..., pp. 10-11. 
establishing the Imperial Court and also regulating the procedure and the execution of its decisions. The court was to decide on competence disputes between judicial and administrative authorities and exercise judicial review over administrative decisions, after the exhaustion the administrative appeal proceedings. Grounds for the latter, called the "special administrative jurisdiction" (Sonderverwaltungsgerichtsbarkeit), was the violation of the citizens' constitutionally guaranteed political rights. Therefore the legal protection of fundamental rights, as subjective public rights, contained in particular in the Act on the General Rights of Citizens (Staatsgrundgesetz über die allgemeinen Rechte der Staatsbürger für die im Reichsrathe vertretenen Königreiche und Länder) was ensured for the first time in the history. ${ }^{9}$ Furthermore, the examination of special claims under public law of the regional authorities of the provincial authorities among themselves, as well as of claims by municipalities, corporate bodies or individual persons, against the regional authority outside the jurisdiction of the ordinary courts, was provided for by its „causal jurisdiction” (Kausalgerichtsbarkeit).

In addition to the protection of fundamental rights by the Imperial Court, Article 15 of the Judiciary Act provided the judicial review of administrative decisions (and thus strengthening the rule of law) in general. ${ }^{10} \mathrm{~A}$ differentiation was made according to the type of claims or rights violated - in all cases, in which the authority had to decide on conflicting claims of private individuals, the party was able to lodge his/her claim before the ordinary courts (Article 15 Section 1). The claim was to be directed against the other party for impairing private rights, not against the decision. However, if someone also claimed that his rights were violated by a decision or an order of the administration, he/she could, according to Article 15 Section 2, lodge a complaint to the Supreme Administrative Court. The latter was to render the administrative decision in public oral proceedings; the party's counterpart was a representative of the administrative authority concerned. In contrast to the special administrative jurisdiction of the Imperial Court, this initially only programmatic clause was not limited to citizens, thus opening the way to the jurisdiction of the Supreme Administrative Court also to non-citizens. ${ }^{11}$ Until the act implementing the provisions of Article 15 was enacted, which was only motivated by the extensive judicature of the Imperial Court, several years passed. The Act of 22 October 1875 establishing the Supreme Administrative Court (Gesetz, betreffend die Errichtung eines Verwaltungsgerichtshofes) adopted the wording of Article 15 Section 2 of the Judiciary Act. According to $\$ 2$ Section 1 of this Act, the complaint could be lodged if

9 E.C. Hellbling, Die Landesverwaltung..., pp. 217-218.

10 Ibidem, p. 218. The legislator's exact motive for the creation of Article 15 has not been clarified so far, legal scholarship later even assumed that it was a random - if rational and intuitively right - guess. T. Olechowski, Der österreichische Verwaltungsgerichtshof. Geschichte der Verwaltungsgerichtsbarkeit in Österreich - das Palais der ehemaligen Böhmisch-Österreichischen Hofkanzlei, Wien 2001, p. 21.

11 E.C. Hellbling, Die Landesverwaltung..., pp. 218-219. 
the interference of the right in question turned out to be unlawful one. These publiclaw claims and obligations concerning the authorities' decisions and orders based on legal grounds contrasted with the acts of the administration in the narrower sense, which should not be decided according to the criterion of legality, but rather that of expediency and were thus excluded from judicial review.

Paragraph 2 Section 2 of the Act of 22 October 1875 clarified that unlawful decisions and orders of all authorities, i.e. state, regional, district and local administration were subject to the jurisdiction of the Supreme Administrative Court; this jurisdiction was also extended to tax and fee matters. However, for matters of administrative penal law (Polizeistrafrecht) the competent jurisdiction was determined according to the provisions of the regulations on administrative penal matters $(\$ 48)$. With regard to the examination of laws and regulations, the jurisdiction of the Supreme Administrative Court was equivalent to that of the ordinary courts $(\$ 8)$, so the Court was competent to examine duly published regulations, but not acts. However, the Court did not decide on merits of the case itself, but had to decide as a rule on the basis of the facts accepted in the last administrative instance ( $\$ 6$ Section 1). It was to annul the decision or order if they were unlawful, stating the grounds for its judgement ( $\$ 7$ Section 1 ). The Supreme Administrative Court's particular importance for the development of the administrative procedural law ultimately was derived from the $₫ 6$ Section 2 of the Act of 22 October 1875 . According to this provision, if the Court found - that the facts of the case were accepted contrary to the records, or that they require essential additions, or - that essential forms of the administrative procedure were disregarded, it had to annul the contested decision or order affected by procedural violation and refer the matter back to the administrative authority, which had to correct the shortcomings and then render a new decision or order. In the shaping of the Supreme Adminis-trative Court's procedural law special attention was paid to the principle of the right of the interested parties to be heard $(\$ 27)$.

The consequences of this provision for the proceedings before the authorities were already known from the start - in the justification of the first government draft from 1873 on the Act of 22 October 1875 it was stated that these requirements concerning the investigation and determination of the facts by the administrative authorities would require the adoption of precise regulations on the administrative procedure, in particular on the procedure of taking evidence carried out in administrative disputes. Although the legislator remained inactive with regard to these regulations for a long time, the establishment of the publiclaw courts as such, in particular the Supreme Administrative Court, had an indirect impact on the administrative procedure. For example, in 1876, in response to this challenge, a decree was issued by the Ministry of Culture and Education, where the "intellectual father of the Austrian administrative jurisdiction" - Karl Freiherr von Lemayer, was the head of a department. Although this decree was originally intended to be used only internally, other authorities began to follow 
its guidelines in order to prevent having their decisions annulled by the Supreme Administrative Court. ${ }^{12}$

The period from 1967 until the outbreak of World War I was characterized by regularly recurring demands for and attempts at a comprehensive administrative reform. At the latest, with the establishment of the Supreme Administrative Court, the need for a reform of the existing procedural provisions beyond issues of administrative organisation was obvious. This need was reinforced by the fact that constitutionalism and thus a changed self-conception of the state also entailed a significant increase in administrative agendas. The comparison with the Prussian system, where the introduction of judicial review was only one aspect of a comprehensive administrative reform, based on the distinction between administrative matters of legal dispute and matters of decision, was referred to as a role model and a point of reference for criticism of the existing form of administrative judicial control as a restricted, extraordinary remedy. ${ }^{13}$ In view of the lack of uniform rather than merely selective regulations, judicature and doctrine gained importance, which - as was highlighted in the course of later reform efforts - led to the development of a kind of "legal practitioners' law" (Juristenrecht), which qualification, as a source of law, was at least problematic. In order to be able to exercise its control over the forms of administrative procedure, the Supreme Administrative Court ultimately had to work out the principles of these forms in its own case law. However, without further developing the law in a manner comparable to the Anglo-American case law - a task that the Court solved in an excellent way, could still not replace comprehensive legal regulations, especially since its judiciary was not able to guarantee the requirement of legal certainty to the same extent. ${ }^{14}$ This was all the more true, since the Court refused to be bound by its own decisions and no organisational precaution like the different panel sizes of the present-day Supreme Administrative Court were provided for by the legislator. ${ }^{15}$

The attempt to systematise the legal material, based on the findings of the Supreme Administrative Court resulted in, what was probably the most significant work on Austrian administrative procedure of that time, the Manual of the Austrian Administrative Procedure, published by the Member of the Supreme Administrative Court - Professor Friedrich Tezner in 1896. He complained that he felt quite isolated in his appreciation of the importance of the administrative procedure. ${ }^{16}$ Although the work itself did not have any intention of further developing the existing law, it has been emphasised in recent research that, as a result,

12 T. Olechowski, Die Entwicklung allgemeiner Grundsätze des Verwaltungsverfahrens, [in:] Allgemeine Grundsätze des Verwaltungs- und Abgabenverfahrens, Red. M. Holoubek, M. Lang, Wien 2006, pp. 24-25.

13 Ibidem, pp. 32-33.

14 E.C. Hellbling, Die Landesverwaltung..., p. 242.

15 T. Olechowski, Die Entwicklung allgemeiner Grundsätze..., p. 28.

16 F. Tezner, Handbuch des österreichischen Administrativverfahrens, Wien 1896, p. III. 
F. Tezner often adopted as a principle not the judicature of the Supreme Administrative Court as such, but generalisations derived from it. ${ }^{17}$

This situation explains the demand for reform, which was emphatically raised in the legal doctrine and practice right from the beginning, and which the Monarchy's legislature also tackled repeatedly and unsuccessfully again and again.

A first practical impetus for reform came in 1884 from the Austrian Advocates' Congress (Österreichischer Advocatentag). ${ }^{18}$ Three of the contributions dealt with a motion of Josef Brunstein, in which he called first and foremost for a reform of the administrative procedure to be recognized as one of the most urgent tasks of legislation. ${ }^{19}$ His motion contained also specific requests for the drafting of the reform and was based on the fundamental distinction between non-adversarial administrative proceedings (being equally in the need of reform) and adversarial administrative proceedings. All three reports recognized the need for reform, but the need to create a special law was questioned. ${ }^{20}$ What is more, the suggestions as to the content of the reforms differed widely. However, at this point the demand for a separate legal framework for administrative procedure was already present. ${ }^{21}$

In the decades that followed, the need for reform seemed to solidify further. Karl Lemayer, who also wrote one of the contributions to the Advocates' Congress, published the Apologetic Studies on Administrative Jurisdiction in 1896, Brunstein held a (subsequently published) lecture on the topic The Administrative Procedure and Its Reform before the Austrian legal society in 1900 and Tezner even published a concrete Legislative Draft regulating the Administrative Procedure in $1902 .{ }^{22}$

From the legislative point of view, a first attempt of a partial reform was made in 1896 in the scope of administrative procedure appeals. This was originated in

17 T. Olechowski, Die Entwicklung allgemeiner Grundsätze..., pp. 28-32 based on the term "party".

18 The Advocates were faced with this complex of problems at first hand as their signatures were necessary for the party's initiation of the proceedings before the public-law courts. In the following years, the advocates supported the implementation of a system of administrative courts on several levels in analogy to the civil justice system. G.D. Hasiba, Die Kommission zur Förderung der Verwaltungsreform (1911-1914), [in:] Recht und Geschichte. Festschrift für Hermann Baltl zum 70. Geburtstag, Red. H. Valentinitsch, Graz 1988, pp. 237-262 (240).

19 J.L. Brunstein, Antrag, [in:] Österreichischer Advocatentag, Drei Gutachten über die Reform des Administrativ-Verfahrens. Dem österreichischen Advocatentag erstattet von Sctionschef Dr. Karl Freiherrn von Lemayer, Regierungsrath Dr. Arnold Pann, Professor Dr. G. Pražak, Wien 1884, p. 1.

20 K. Lemayer, Gutachten, [in:] Österreichischer Advocatentag, Drei Gutachten..., pp. 23-24.

21 A. Pann, Gutachten, [in:] Österreichischer Advocatentag, Drei Gutachten..., p. 37.

22 C. Lemayer, Apologetische Studien zur Verwaltungsgerichtsbarkeit, Wien 1896; J.L. Brunstein, Das Administrativ-Verfahren und seine Reform, Wien 1900; F. Tezner, Praktische Vorschläge zur Reform des österreichischen Administrativverfahrens, "Allgemeine österreichische Gerichtszeitung" 1902, Nr. 53, pp. 51-54, 60-64, 76-78 and 83-86. These three publications were - together with the Draft of the Commission to Promote the Administrative Reform - also mentioned in the explanatory remarks accompanying the Administrative Procedure Draft in 1925. 
a government draft, introduced in 1894 in order to limit the period for appeal to four weeks, after the Supreme Administrative Court ruled that the procedure was inadmissible, due to the lack of a sufficient legal basis. The responsible committee in the Chamber of Deputies decided that the lack of a general law on the administrative procedure not only meant a difficulty for the parties involved, but could also jeopardise legal certainty, so that - at least concerning the part of the appeal procedure - a uniform regulation should be created. ${ }^{23}$ In addition to the administrative procedural law, the parliament discussed other administrative deficiencies, in particular the duality of the administration. The reform served as a model for two acts on administrative procedure on a regional level, but, overall, did not bring the desired success.

A few years later, under Prime Minister Ernest von Körber, another reform project was launched, which did not lead to a legislative act. However, its results were published in 1904/1905 as Studies on the reform of internal administration and discussed in detail among experts. ${ }^{24}$ First of all, the studies enumerated the deficiencies in administration and found among other things, that the regulations on the administrative procedure were scattered across several legal sources, partly in general, partly in special terms, in part outdated, in part inappropriate and above all incomplete. It was expressly stated that an appropriate regulation of the administrative procedure was of greater importance than just the reform of the administrative organisation, although the „enactment of appropriate procedural regulations (including the area of administrative penal law)" was only one of several reform goals. ${ }^{25}$ Even less than two years later, Prime Minister Max Wladimir von Beck, writing to the ministers, also pointed out the urgency of an administrative reform.

As a matter of fact, the work on an administrative reform was only resumed in 1911, when Prime Minister Erwin von Schwartzenau set up a Commission to Promote the Administrative Reform. This top-class commission was tasked with taking part as an advisory body in the

Preparation of the reform of the internal administration as well as the financial management and the education. [...] Its activities was to include the organisation of the administrative authorities, the day-to-day administration and the procedure. ${ }^{26}$

23 T. Olechowski, Die Entwicklung allgemeiner Grundsätze..., pp. 37-38.

24 See also E. Bernatzik, Studien über die Reform der inneren Verwaltung. Einleitender Vortrag zur Plenarversammlung der Wiener Juristischen Gesellschaft am 25. Jänner 1905, "Allgemeine österreichische Gerichts-Zeitung” 1905, Nr. 56, pp. 43-48; as well as: Diskussion über die Denkschrift der Regierung: Studien zur Reform der inneren Verwaltung: 25. Jänner bis 22. Februar 1905, Wien 1905; G.D. Hasiba, Die Kommission zur Förderung..., pp. 240-241f.

25 E. Koerber, Studien über die Reform der inneren Verwaltung, Wien 1905, cited after E. Bernatzik, Studien..., p. 43. Bernatzik himself discussed in his lecture the administrative organization and the administrative jurisdiction, but not the administrative procedure.

$26 \S 2$ der Allerhöchst genehmigten Grundsätze für die Tätigkeit der Kommission zur Förderung der Verwaltungsreform, printed in “Wiener Zeitung”, Nr. 120 of 25 May 1911, pp. 1-2. 
Its final results were to be presented to the emperor by means of proposals and reports on the prime minister; moreover, the Commission had to report annually on its work. Its duration was originally set at three years, with the possibility of applying for an extension. Despite its successful request for renewal, its extensive work was interrupted by the outbreak of World War I, even if the commission's office existed until 1917.27

One of the four committees of the Commission was responsible for the decisive provisions on the proceedings before the administrative authorities in general or regarding special branches and soon identified the lack of uniform procedural principles as the most serious deficiency. It therefore began to prepare a draft regulation. Two years later, a corresponding draft was available in form of the proposals for the adoption of rules of procedure of the district authorities and the establishment of principles for the procedure before the political authorities, ${ }^{28}$ which consisted of two parts and a series of introductory articles. As it was not to anticipate the overall results of the Commission, the draft only aimed at a partial reform in order to remedy particular shortcomings regardless of any necessary organisational changes; the second part of the regulation, regarding the procedural principles related to the proceedings before the public authorities at all levels with the exception of administrative penal matters (Polizeistrafsachen). ${ }^{29}$ Overall, given the urgency of the reforms, the regulation was intended to be only provisional and was not to replace the special procedural regulations already in force, even though the systematisation of the procedural principles had already been undertaken with the view of preparing a statutory procedural regulation.

Not least because of its legal basis, which had been controversial within the Commission, the regulation was not intended as a legal reorganisation, but rather meant to clarify the law in force and the obligation of the authorities to comply with it. According to the Commission, this law resulted not only from the existing legal acts enacted in form of laws and regulations, but also from the jurisdiction of the Supreme Administrative Court. The content of the procedural principles established by the Court was regarded as representing the essence of administrative proceedings in Austria. Although the two parts of the draft were based on different legal bases, there was an inner connection between them - without reforming the internal service, an accelerated activity of the authorities did not appear to be

27 The Commission held its last plenary session on 15 December 1914, it was officially declared closed by a "allerhöchstem Handschreiben" on 25 December 1915, G.D. Hasiba, Die Kommission zur Förderung..., pp. 261-262.

28 Anträge der Kommission zur Förderung der Verwaltungsreform betreffend die Erlassung einer Geschäftsordnung der k.k. Bezirkshauptmannschaften und die Feststellung von Grundsätzen für das Verfahren vor den politischen Behörden samt Erläuterungen des Referenten Erwin Freiherrn von Schwartzenau und einem Bericht des Mitgliedes Erich Grafen Kielmansegg über die Kanzleireform bei den politischen Behörden, Wien 1913.

29 E. Schwartzenau, Erläuterungen, [in:] Anträge der Kommission..., p. 1. 
possible, even if the principles of administrative procedure were standardised. The first part of the draft contained the provisions on the rules of procedure for the district authorities and the second one - the provisions for the principles of administrative procedure. The principles lived up to their name in that it was attempted to set very basic principles, for example by clarifying the concept of political authority (Article VII, $\$ 1$ of the procedural principles). In terms of content and form, the procedural regulation was based on a sharp distinction between administration in the narrower sense and matters of administrative jurisdiction which were subject to review of the Supreme Administrative Court. The former was to constitute the actual task of the authorities and was naturally not tied to any special forms. Contrarily, the term "procedure" was supposed to comprise the activities of the authorities that dealt with the respective interests (including, not least, the public interest) directed at reaching an official decision or order by the authority. In $₫ 3$ of the draft, the scope of the procedural regulations was described on the basis of this distinction. ${ }^{30}$

All in all, it has to be emphasised that both official attempts at a general reform considered procedural law to be part of a comprehensive administrative reform, with the focus not only on the administrative organisation, but also on the training of civil servants and thus on the law curriculum as well.

\section{The Reorganisation of Administration and Its Procedure by the Austrian Republic}

After the emergence of the new republic and the break in the legal continuity that came with the decision to found a new state on 30 October $1918,{ }^{31}$ the law of the monarchy in the field of administrative procedure was adopted by way of a general transition of the law in $\$ 16$ of this Act. Around two years later, on 1 October 1920, the Federal Constitutional Law (Bundesverfassungsgesetz, B-VG) came into force and laid the grounds for the reorganisation of the administration, although the questions of administrative reform were initially less urgent than constitutional matters. According to Article 2 B-VG, the Republic was established as a federal state; the Federal Constitutional Law regulated the central organisation of the executive at the federal level in its third, and the legislative and executive of the federal provinces in its fourth part.

30 Ibidem, p. 7-34.

31 Beschluss der Provisorischen Nationalversammlung für Deutschösterreich vom 30. Oktober 1918 über die grundlegenden Einrichtungen der Staatsgewalt, StGBI 1/1918. 
The distribution of competences between the federal state and the provinces was laid down in Article 10-15 B-VG. However, the coming into force of Articles 10-13 and 15 was temporarily suspended, according to Section 42 of the Constitutional Transition Act of 1920, because "the immediate, actual division of the spheres of activity assigned to the federal state or the provinces [...] was faced with major obstacles insofar as the entire administration at the federal and regional level was not reorganised". ${ }^{32}$ This primarily concerned the organisation of general state administration in the federal provinces, especially at the local level. Before 1920, the Supreme Administrative Court was entrusted with reviewing administrative decisions. After the exhaustion of the administrative appeal proceedings, the Court ruled on the legality of decisions and orders of administrative authorities, with the exception of violations of constitutionally guaranteed rights. ${ }^{33}$

\section{The Acts on Administrative Procedure of 1925}

When the administration was reorganised in 1920, the question of a reform of the administrative procedure was not in the foreground. In addition to the inefficient organisation of the administration, which was still characterized by the duality of two separate administrative apparatuses, now at the level of the federal state and the federal provinces, and which were improved to some extent through the creation of the indirect federal administration (Article 102 B-VG), the Republic was faced primarily with a personnel problem, since the size of the central civil service had to be adjusted to the new situation after the collapse of the monarchy. The problem was reinforced by the ongoing financial and economic difficulties of the new state, so that, as Merkl noted in 1921, the administrative problem was not a procedural or organisational problem, but a financial problem where the reduction of costs was paramount. ${ }^{34}$

After drafts of administrative procedurallaws were submitted in 1919 (but were no longer dealt with in parliament), a "Savings Commission" (Ersparungskommission)

32 Bericht des Verfassungsausschusses über den Entwurf eines Gesetzes, womit die Republik Österreich als Bundesstaat eingerichtet wird, 991 BlgKNV, [in:] Die Bundesverfassung vom 1. Oktober 1920, Red. H. Kelsen, G. Froehlich, A. Merkl, Wien, Leipzig 1922, pp. 507-520.

33 Those were transferred to the competence of the Imperial Court - the successor of which was the newly created Constitutional Court - Article 144 B-VG.

34 A. Merkl, Zum Problem der Verwaltungsreform, "Zeitschrift für Verwaltung" 1921, pp. 163-174, [in:] Adolf Julius Merkl. Gesammelte Schriften III/I, Red. D. Mayer-Maly, H. Schambeck, W.-D. Grussmann, Berlin 2006, pp. 113-124 (113-114); see also G.D. Hasiba, Ein Meisterwerk österreichischer Gesetzgebungskunst, die Genesis der Verwaltungsreformgesetze von 1925, Graz 1987, p. 167. 
led by the former prime minister Beck was set up as a result of a note from the Inter-Allied Reparations Commission. The Savings Commission was composed of experts from various administrative branches and was given organisational support by the Department of Administrative Reform at the Federal Chancellery. According to its statute, the Commission was tasked with examining budgetary improvement options through regular reviews of the federal budget and the entire management of the administration as well as other suitable measures for budget restructuring, but soon a reorganisation of the administration was discussed. The administrative procedure initially fell behind and was therefore not explicitly mentioned in the catalogue of priorities presented by the Commission in December. In the area of administrative penal procedure, an reform attempt was made (in connection with the extension of the jurisdiction of the Administrative Court to these matters), but the draft was not followed up in the course of the legislative process. ${ }^{35}$

Finally, the decisive impetus for the implementation of further reform work - not least for economic reasons - came from outside, in the form of the so-called Geneva Protocols. As the Republic was unable to consolidate financially and economically, the Geneva Protocols, international treaties concluded under the aegis of the League of Nations, granted the Austrian government a loan for which certain members of the League of Nations guaranteed. This granting was linked to political concessions ${ }^{36}$ and subject to strict conditions in order to ensure that the money was only used in accordance with the objective of economic and financial reconstruction. The third protocol was devoted to Austria's commitments in detail - among other things, Austria committed to draw up a programme of reforms and improvement, to be realised in stages and designed to enable Austria to re-establish a permanent equilibrium of its budget within two years. According to Article VI lit $\mathrm{d}$, the Austrian government promised to "take and carry out all decisions necessary for the full realisation of the program of reforms, including all necessary adminis-trative reforms and the indispensable alterations in the legislation". Alfred Zimmermann, who had the necessary specialist knowledge and, as it turned out, took this task quite seriously, was seconded as Commissioner General of the League of Nations. The domestic implementation of the Geneva program was based on the "Reconstruction Law" (Wiederaufbaugesetz), ${ }^{37}$ which stipulated first and foremost an administrative reform. The administrative reform was therefore again part of a comprehensive reform program, the preparation of which was entrusted to the Department for Administrative Reform under the direction of Egbert Mannlicher.

35 G.D. Hasiba, Die Kommission zur Förderung..., p. 239; idem, Ein Meisterwerk..., p. 169.

36 In particular Austria had to agree to an affirmation of the so-called Anschlussverbot stipulated in Article 88 of the Treaty of St. Germain, as Austria also had to agree to its economic and financial independence (Restoration of Austria, Protocol I October 4, 1922, LNTS 12, p. 387).

37 Bundesgesetz vom 27 November 1922 über die zur Aufrichtung der Staats- und Volkswirtschaft der Republik Österreich zu treffenden Maßnahmen (Wiederaufbaugesetz), BGBI 842/1922. 
The Savings Commission was dissolved and a "Savings Commissioner" reporting to the Ministry of Finance was appointed instead. ${ }^{38}$

The Acts on Administrative Procedure, introduced on 5 June 51924 in the National Council as "Acts to Facilitate Administration" (Gesetze zur Vereinfachung der Verwaltung), were the first results of the reform work. The draft was divided into two parts and constructed a package of acts. The first part contained the three Acts on Administrative Procedure: the General Administrative Procedures Act (Allgemeines Verwaltungsverfahrensgesetz - AVG), the Administrative Penal Act (Verwaltungsstrafgesetz - VStG) and the Administrative Enforcement Act (Verwaltungsvollstreckungsgesetz - VVG) together with the Introductory Act to the Administrative Procedure Acts (Einführungsgesetz zu den Verwaltungsverfahrensgesetzen - EGVG) and a constitutional law that provided the basis of competence. The second part, the Administrative Relief Act, on the other hand, did not relate to procedural law and aimed at simplifying the provisions of federal administrative law, that were not affected by the standardisation of procedural provisions. In his report before the National Council, the rapporteur looked back at the decades of efforts towards an administrative reform and emphasised that, unlike in the previous attempts, this time the "austerity" was in the foreground. The draft would take the financial and reform programs fully into account but without neglecting the other improvements that could be reconciled with this idea. After consultation in the Constitutional Committee, the laws passed the National Council in the third reading with only minor changes about year later, on 27 July $1925^{39}$ - even before the adoption of the distribution of competences and the reform of the administrative organisation, which in particular also entailed the long-awaited elimination of the duality in the administration apparatus. ${ }^{40}$ In view of the strong discord between the political parties and the difficulties in the other areas, in particular with regard to the distribution of competences, it is remarkable that during the deliberations on the administrative procedural laws "a marked difference between the parties was not to be felt". ${ }^{41}$

In terms of the legal basis, the initial situation before the creation of the Acts on Administrative Procedures can be summarised in by placing the various existing norms into three different groups:

1. Certain procedural rules that were implemented in the course of the substantive regulation of the matter concerned.

The older regulations from the time of the monarchy were included in different legal acts, like decrees (Hofkanzleidekrete and Hofkammerdekrete)

38 G.D. Hasiba, Ein Meisterwerk..., p. 169.

39 BGBI 273-277/1925. They entered into force on January 1, 1926. See also E. Mannlicher, Die österreichische Verwaltungsreform des Jahres 1925, Wien 1926, p. 4; "Sonderabdruck aus der Zeitschrift für öffentliches Recht" 1925, Nr. 5.

40 These changes were enacted on 30 July 1925, BGBI. 268/1925.

41 G.D. Hasiba, Ein Meisterwerk..., p. 180. 
and regulations. The increase in administrative matters during constitutionalism and their diversity also resulted in a corresponding increase and differentiation of the special procedural rules. Before the Acts on Administrative Procedures were enacted, there were several special procedural rules such as separate water, construction and trade law procedures, and at the regional level, for example, the Lower Austrian agricultural laws contained a comprehensive procedural regulation. Also the so-called "Floggings $\mathrm{Pa}$ tent" (Prügelpatent), ${ }^{42}$ an Imperial Regulation of 20 April 1854, contained both substantive administrative (penal) law and detailed regulations on the enforcement proceedings, with the majority of the provisions concerning procedural matters.

2. Legislation of various kinds with procedural content, partly having been generalized or expanded by the jurisdiction of the Supreme Administrative Court.

At this point, the official instructions (Amtsinstruktionen and Amtsanordnungen) or other internal requirements need to be mentioned, which focused less on the persons, affected by the activities of the authorities, but rather on the respective officials, and in practice offered assistance or some sort of guidelines for their work. This holds true for example for the Ministry of Culture and Education's decree already referred to; even more important, specifically for the drafting of the General Administrative Procedures Act, was the official instruction from 1855. Apart from that, various decrees sometimes also solely contained partial procedural regulations, ranging from regulations concerning the delivery of official documents to the use of administrative fines. Competence and procedural regulations were also enacted by means of (Ministerial) Regulations (MinisterialVerordnungen), 1896 the already mentioned legislative attempt to regulate the appeal procedure was made.

3. The principles developed in the judicature of the Supreme Administrative Court.

These were already mentioned in the reform proposals of the Administrative Reform Commission as a source of legal knowledge (if not of law) and were also extensively processed through legal practice and teaching, the aforementioned work of Tezner arguably being the best-known among them. In particular - according to the travaux prépatoires - one of the most important provisions of the draft, constituting the basis for its entire structure, namely $\$ 9$ AVG (which differentiates the capacity to be a party to the proceedings), originated in theory and judicature.

42 On its content see E.C. Hellbling, Die Landesverwaltung..., pp. 231-233. The designation originates from its $\S 11$ Section 2, which stipulated, that in some cases instead of the arrest, the authorities were to resort to "corporal punishment" (körperliche Züchtigung). 
In terms of content, the creators of the administrative procedural laws were able to fall back on what already existed, despite its fragmentation, even though there were no international models in terms of a comparable comprehensive statutory regulation of administrative procedural rules. ${ }^{43}$ The ongoing reform efforts also resulted in a theoretical penetration of the area, including the judicature of the Supreme Administrative Court, so that the reform was "less a matter of new ideas, than a appropriate utilisation and arrangement of the existing useful" material. A particular difficulty arose, however, from one of the greatest achievements of the reform of the administrative procedure, namely the separation of the procedural from the substantive provisions without affecting the most important principles of the applicable substantive administrative law. This was obviated due to the level of abstraction on the one hand, and the inclusion of transitional regulations, not only in the Introductory Act, but also in the Administrative Procedure Acts themselves, on the other. Irrespective of the existing administrative (procedural) law, single regulations from civil procedural law were also used additionally as models.

Overall, the procedural laws aimed for a comprehensive standardisation of the procedure for as many administrative authorities as possible, by as few procedural rules as possible. ${ }^{44}$ The older regulations were removed, and special regulations should only be used where the new procedural laws themselves expressly referred to them. The scope of application of the Acts on Administrative Procedure was defined in the Introductory Act - Article II EGVG stipulated, which authorities had to apply the respective Acts. According to Article XI $\$ 5$ of this Act, the new regulations already had to be applied to pending proceedings. Apart from that, the EGVG also contained substantive regulations, namely the penal provisions of Articles VII-IX, which were originally intended as a temporary solution until the enactment of a comprehensive administrative penal code. The centre of the reform, of course, were the three Acts on Administrative Procedure, based on the natural model of the corresponding judicial laws (Code of Civil Procedure, Code of Criminal Procedure, Enforcement Code), the general administrative procedure in the AVG, the administrative criminal procedure in the VStG and the administrative enforcement in the VVG.

Among these, the AVG in turn was the basis of the entire procedural reform, with the aim of establishing general principles of the administrative procedure, regulated both: the investigative and the appeal proceedings, as well as central questions such as the legal determination of the position of parties and participants to the proceedings and the introduction of a specific form for the decisions of the administrative authorities. Accordingly, both the VStG and the VVG, determined their applicability in relation to the AVG. The VStG, which

43 E. Mannlicher, Die österreichische Verwaltungsreform..., p. 6.

44 L. Adamovich, Österreichisches Verwaltungsverfahren, Wien, Leipzig 1926, p. 4. 
was successfully passed before an agreement on an administrative penal law code (and in particular the delimitation from judicial criminal law) could be reached, aimed in all material aspects at the codification and shaping of the applicable law. In addition to the comprehensive regulation of administrative penal proceedings, with special regard to party rights from the time of arrest, notably a general mandate penalty procedure (Strafmandatsverfahren) and the mandate penalties imposed by the administrative authorities (Organstrafmandat), both of them summary proceeding, were introduced. The VVG differed from the AVG and VStG in the brevity of their regulations, which is explained by the aim of shifting the focus regarding executions to the courts, ${ }^{45}$ this was particularly true for the collection of cash payments. With regard to the enforcement proceedings, it referred to a large extent to the AVG.

\section{Further Developments}

Subsequently, the Austrian Acts on Administrative Procedures were adopted into the legal system of the Second Republic; there was a renotification (Wiederverlautbarung) in 1950 and 1991, for the introductory Act also a third time in 2008. The most significant amendment to the Austrian administrative procedure since then was the implementation of the two-step procedure of judicial review on January 12014 , which now - as a rule - provides a complaint before the regional Administrative Court instead of an administrative appeal. ${ }^{46}$ The relevant provisions of the AVG were used as a primary model for the regulation of the procedure before the administrative courts, also, the Administrative Court Procedure Act stipulates the subsidiary application of the AVG (with the exception of Sections 1-5 and Part IV) and the VStG, as well as the mutatis mutandis application of some provisions of both Acts. The amendment to the EGVG replaced the previously exhaustive (and steadily expanded) list of authorities that obliged to apply the administrative procedural acts in each case by a general clause. Overall, therefore, these recent developments can be viewed as a confirmation of the quality and importance of the Acts on Administrative Procedures, the history of which goes back well before their enaction in 1925. Neither before 1876, nor until 1925, could the administrative procedure, although "deficient and incomplete" 47 at that time, be described as "non existent" 48

45 G. Kaniak, Die Verwaltungsvollstreckungsgesetz-Novelle 1949, "Österreichische Juristen-Zeitung" 1949, Nr. 4, pp. 509-513 (509).

46 Verwaltungsgerichtsbarkeits-Novelle 2012, BGBI I 51/2012.

47 K. Lemayer, Gutachten..., p. 11.

48 This view - with regard to the legal situation in 1876 - is also expressed by T. Olechowski, Die Entwicklung allgemeiner Grundsätze..., p. 21. In the same direction pointed already Tezner, 
or "almost random". ${ }^{49}$ On the contrary - neither the judicature of the Supreme Administrative Court nor the scholars tried to reinvent the wheel, but rather aimed to embed what already existed in a greater structure, although, of course, this went beyond a mere compilation. Therefore, it seems more than justified to honour the Acts on Administrative Procedure passed in 1925 as a remarkable codification, which - beyond being simply a reform of administrative proceedings - continues to form the basis of the procedure before the Austrian administrative authorities and a core element of the rule of law.

\section{Postępowanie administracyjne w Austrii - od monarchii do republiki}

Historyczny rozwój prawa administracyjnego Monarchii Austro-Węgierskiej i Austrii do czasu ustanowienia ustawy o ogólnym postępowaniu administracyjnym z 1925 r. można podzielić na kilka etapów, wyznaczonych przez okres administracji ukształtowanej stanowo, administracji czasów monarszego absolutyzmu i wreszcie - od konstytucji grudniowej z 1867 r. - administracji zorganizowanej wedle zasady praworządności. Rok 1867 skutkował - w związku z nadejściem liberalizmu - ostatecznym rozdzieleniem sądownictwa i administracji do najniższego szczebla. Również kontrola administracji została powierzona już nie sądom zwyczajnym, ale specjalnemu sądownictwu administracyjnemu, składającemu się z Cesarskiego Trybunału Sprawiedliwości (Reichsgericht) i Trybunału Administracyjnego (Verwaltungsgerichtshof).

$\mathrm{Na}$ mocy konstytucji grudniowej każdy, kto twierdził, że jego prawa zostały naruszone przez orzeczenie lub zarządzenie władzy, mógł odwołać się do Trybunału Administracyjnego. Jak wynikało z ustawy z 22 października $1875 \mathrm{r}$. o Trybunale Administracyjnym, skargę można było wnieść na sprzeczne z prawem orzeczenia wszystkich organów administracji. Trybunał nie rozstrzygał w sprawie samodzielnie, lecz rozpoznawał sprawę $\mathrm{z}$ reguły na podstawie przyjętego $\mathrm{w}$ ostatniej instancji administracyjnej stanu faktycznego ( $\$ 6$ ust. 1) i mógł uchylić decyzję jako sprzeczną z prawem, podając $\mathrm{w}$ uzasadnieniu powody takiego rozstrzygnięcia. Szczególne znaczenie orzecznictwa Trybunału dla rozwoju prawa administracyjnego pozostawało $\mathrm{w}$ związku z brzmieniem $₫ 6$ ust. 2, zgodnie z którym Trybunał, stwierdziwszy, że stan faktyczny jest sprzeczny $\mathrm{z}$ aktami sprawy albo że wymaga on uzupełnienia $\mathrm{w}$ istotnym zakresie, albo że pominięto istotne formy postępowania

when he criticized that the "most excellent teachers of German constitutional law" would still insist on a general informality of administrative procedure, F. Tezner, Handbuch..., p. III. 49 A view taken by G.D. Hasiba, Ein Meisterwerk..., p. 164. 
administracyjnego, powinien uchylić zaskarżone orzeczenie lub zarządzenie i przekazać sprawę organowi. Powodowało to, podobnie jak samo wprowadzenie sądowej kontroli administracji, że organy, dążąc do uniknięcia uchylania ich orzeczeń przez sąd administracyjny, starały się respektować wynikające z jego orzecznictwa zasady.

Okres od 1876 r. do wybuchu pierwszej wojny światowej obfitował w rozmaite postulaty i próby kompleksowej reformy administracji. Wobec braku jednolitych przepisów regulujących sposób jej funkcjonowania na znaczeniu zyskiwały orzecznictwo i nauka jako czynniki decydujące o rozwoju „prawa prawników-praktyków" (Juristenrecht), którego charakter - jako źródła prawa - był co najmniej problematyczny. Tłumaczy to eksponowaną w nauce i praktyce potrzebę reformy, której próby urzeczywistnienia podejmowane były wielokrotnie, acz nieskutecznie przez władzę ustawodawczą.

Pierwszy reformatorski impuls datowany jest na 1884 r., kiedy to podczas austriackiego Dnia Adwokata sformułowano wiele różnorodnych propozycji reform $\mathrm{z}$ jednolitą $\mathrm{w}$ ich ramach ideą oddzielenia formalnego i materialnego prawa administracyjnego. Ze strony ustawodawcy pierwszą próbę reformy podjęto w 1896 r., decydując się na częściową regulację środków odwoławczych przysługujących na drodze administracyjnej. Komisja ustawodawcza podkreślała, że brak ogólnej ustawy o postępowaniu administracyjnym oznacza nie tylko utrudnienia dla uczestników postępowania, ale może również zagrażać pewności prawnej. Reforma posłużyła jednak tylko za wzór dla dwóch krajowych ustaw o postępowaniu administracyjnym, nie przynosząc poza tym pożądanego rezultatu. Prace nad reformą wznowiono kilka lat później z inicjatywy premiera Ernesta von Körbera. Nie doprowadziły one wprawdzie od uchwalenia żadnego aktu prawnego, ale ich wyniki zostały opublikowane na przełomie lat 1904 i 1905, stanowiąc podstawę do dalszej dyskusji na ten temat. Stwierdzono wówczas wyraźnie, że odpowiednie uregulowanie procedury administracyjnej ma większe znaczenie niż tylko reforma administracji, mimo że uchwalenie odpowiednich przepisów proceduralnych było tylko jednym z kilku celów reformy. Prace nad reformą administracyjną wznowiono faktycznie dopiero w 1911 r. z inicjatywy premiera Erwina von Schwartzenau, który w tym celu powołał specjalną Komisję ds. Reformy Administracji. Jej prace przerwał jednak wybuch pierwszej wojny światowej. Nie sposób jednak nie zauważyć, że podejście rządu do sprawy reformy nie koncentrowało się na prawie procesowym jako takim, lecz na ujęciu tej kwestii jako części kompleksowej reformy administracji.

Po powstaniu republiki, mimo zerwania na mocy decyzji o utworzeniu nowego państwa z 30 października 1918 r. ciągłości z prawem monarchii, zdecydowano się jednak na przejęcie go w sferze postępowania administracyjnego. Dwa lata później - 1 października 1920 r. - weszła w życie federalna ustawa konstytucyjna (B-VG), która położyła podwaliny również pod reorganizację administracji, mimo że kwestie reformy administracyjnej były początkowo mniej pilne niż kwestie konstytucyjne. Podobnie jak przed 1920 r. kontrola administracji została powierzona Trybunałowi Administracyjnemu, który po wyczerpaniu toku instancji 
administracyjnych orzekał o legalności orzeczeń i zarządzeń organów administracyjnych, z wyjątkiem naruszenia praw gwarantowanych konstytucyjnie.

W 1919 r. opracowano dwa projekty ustaw o postępowaniu administracyjnym, jednak nie nadano im biegu w toku prac parlamentarnych, podobnie jak niepowodzeniem zakończyła się podjęta w 1922 r. próba reformy samego tylko prawa o postępowaniu karno-administracyjnym. Decydujące znaczenie dla prac reformatorskich miał ostatecznie czynnik zewnętrzny w postaci tzw. protokołów genewskich, które zostały wdrożone na szczeblu krajowym w drodze ustawy o odbudowie z 11 grudnia 1922 r. Projekty ustaw o postępowaniu administracyjnym stanowiły wynik pierwszego etapu prac reformatorskich - zostały one złożone w parlamencie 5 czerwca 1924 r. jako ustawy dotyczące uproszczenia działania administracji. Projekt składał się z sześciu ustaw i został podzielony na dwie części. Pierwsza część zawierała trzy ustawy o postępowaniu administracyjnym, regulujące ogólne postępowanie administracyjne (AVG), postępowanie karno-administracyjne (VStG) i postępowanie egzekucyjne $\mathrm{w}$ administracji (VVG). Towarzyszyły im ustawy tworzące podstawy kompetencyjne organów administracji: wprowadzająca (EGVG) oraz ustrojowa. Druga część, dotycząca przepisów o odciążeniu administracji, odnosiła się do prawa materialnego. Ustawy te, uchwalone 27 lipca 1925 r., weszły w życie 1 stycznia 1926 r.

Austriackie ustawy o postępowaniu administracyjnym zachowały moc prawną po powstaniu Drugiej Republiki. Ustawa wprowadzająca była w związku z tym publikowana trzykrotnie - w 1950, w 1991 i w 2008 r. Najważniejszą od tego czasu zmianą $\mathrm{w}$ austriackim prawie o postępowaniu administracyjnym było wprowadzenie - z mocą od 1 stycznia 2014 r. - dwustopniowego sądownictwa administracyjnego i zastąpienie $\mathrm{w}$ związku $\mathrm{z}$ tym odwołania $\mathrm{w}$ administracyjnym toku instancji innym środkiem ochrony, tj. skargą do sądu administracyjnego.

(tłum. Agnieszka Krawczyk)

Laura Rathmanner, Mag, is an Assistant (prae doc) at the University of Vienna at the Law Faculty, Department of Legal Philosophy. Formerly Collaborating Student and Assistant (prae doc) at the Department of Legal and Constitutional History and Research Assistant at the Commission for Austrian Legal History at the Johannes Kepler University Linz and the Austrian Academy of Science at the as a part of a project research team on the legal significance of the Treaty of St. Germain, her research fields include history of public law and legal theory. The theory and history of the principles of administrative procedure and the administrative jurisdiction are subject of her $\mathrm{PhD}$ project. 


\title{
Chapter III Austria
}

\author{
Peter Chvosta, Dr. jur. \\ Judge and Head of Chamber \\ of the Austrian Federal Administrative Court \\ peter.chvosta@bvwg.gv.at
}

\section{Introduction}

In 1925, the General Administrative Procedure Act (GAPA) ${ }^{1}$ was not only the first codification of rules of administrative procedure worldwide, ${ }^{2}$ it was also regarded as a masterpiece of Austrian legislation. ${ }^{3}$ Facing a severe financial crisis in the 1920s that threatened the very existence of the Austrian Republic after the end of the First World War, the GAPA was supposed to contribute to making Austria's administration more efficient and cost-effective by uniform procedural rules. ${ }^{4}$ The GAPA did not only meet these expectations. Furthermore, it was decisively responsible for the paradigm shift of the Austrian administration which was in the 1920s

1 The Law was announced on 21 July 1925 by the F.L.G. (abbreviated herafter: F.L.G.) No. 274/1925, renotified by F.L.G. No. 172/1950 and No. 51/1991. On 21 July 1925 there was also published the Administrative Penal Act by the F.L.G. No. 275/1925 and the Administrative Enforcement Act by the F.L.G. No. 276/1925. Both laws refer for substantial parts to the GAPA. This package of laws was accompanied by the Introductory Law to the laws governing administrative procedure, F.L.G. No. 273/1925, which contains the categories of administrative law excluded from the scope of the GAPA. An english version of the GAPA is available at: https://www.ris.bka.gv.at/Dokumente/Erv/ERV_1991_51/ERV_1991_51.pdf (accessed: 15.01.2020).

2 However, as early as 1928 in Poland and Czechoslovakia, and 1930 in Yugoslavia, administrative procedural laws followed, which were influenced by the Austrian model. See H. Schäffer, Administrative Procedure in Austria, 80 years of codified procedure law, "European Review of Public Law” 2005, vol. 17, no. 2, p. 871(872).

3 In that sense for example K. Ringhofer, Zur Frage des Parteibegriffes im Verwaltungsverfahren, "Österreichische Juristenzeitung" 1950, p. 269; likewise E. Wiederin, [in:] Administrative State, eds. A. Bogdandy, P. Huber, S. Cassese, Oxford 2017, p. 143. Unfortunately this classification cannot be confirmed to most of the amendments to the GAPA which followed during the last decades.

4 See E. Wiederin, [in:] Administrative..., p. 149. 
still marked by the dusty glamour of a multi-ethnic empire of the glory past. The Austrian bureaucracy had to get rid of an outdated understanding of the role of an imperial executive dealing with its subjects. With the GAPA the Austrian administration turned into a service-oriented bureaucracy within a democratic republic - and thus also found its way into the 20th century.

\section{The GAPA of 1925 until now}

\subsection{The GAPA in the course of time}

The GAPA proved to be remarkably durable and "resistant to amendments". Since the GAPA came into force, it has been amended again and again, but the adjustments were mostly minor. ${ }^{6}$ In substance, the GAPA remained largely unchanged, which was not only due to the legal quality, but also due to the limitation of the regulatory content in the GAPA to the most essential procedural aspects. ${ }^{7}$

Of course, the progress of technological development made it necessary to adapt the GAPA. Therefore, the legislator adapted regulations to allow so-called "computer rulings", ${ }^{8}$ the communication between authorities and parties via e-mail ${ }^{9}$ or to consider a possible electronic file management. ${ }^{10}$ Some problems which emerged in practice and contradicted the objectives of the law were also resolved by the legislator. ${ }^{11}$

5 In that sense H. Schäffer, Administrative Procedure..., p. 871(888).

6 See T. Öhlinger, 60 Jahre Verwaltungsverfahrensgesetze - Verwaltungsstrafrechtsreform: Sind die Österreichischen Verwaltungsverfahrensgesetze noch zeitgemäß?, [in:] Verhandlungen des 9. "Österreichischen Juristentages 1985", vol. I, 2nd part, p. 5.

7 For further details see below 3.1.

8 Section 18 Section 4 GAPA.

9 Section 13 § 2 GAPA.

10 Section 17 § 1 GAPA.

11 For example, the provision of Section $71 \S 1$ of the GAPA, about the reinstatement into the previous legal position against failure to observe a time limit, which was granted only in case of the absence of any fault for failure, has been extended to those cases where there was only a fault to a minor degree (F.L.G. No. 357/1990). Definition problems regarding the question of which deficiencies of an application are accessible to an official improvement order according to Section $13 \S 3$ GAPA were also solved by the legislator in a citizen-friendly manner (F.L.G. No. 158/1998). For further details see J. Hengstschläger, D. Leeb, Kommentar zum Allgemeinen Verwaltungsverfahrensgesetz I, Wien 2014, Section 13 GAPA § 27. 


\subsection{The GAPA - a milestone and a great obstacle?}

Over the decades, however, the GAPA as a milestone for the development in public law ${ }^{12}$ has not only had a progressive impact on Austria's development in this field. It seems that it was exactly the positive effects of the GAPA on the efficiency of administrative practice that contributed to prolonging the life of an outdated system of legal protection in administrative matters.

Especially the construction of legal protection in Austria with several stages of review within the administration hierarchy and with just one special Supreme Administrative Court with only limited control powers turned out to be a problem when the European Convention on Human Rights (ECHR) came into force in Austria 1958, in particular because of the guarantees of Article 6 ECHR. ${ }^{13}$ The calls for a reform of the administrative jurisdiction system, which had already been created in this form in 1875, was countered by the very existence of the GAPA and its effectiveness, which would decisively facilitate an efficient judicial control of the whole Austrian administration by the Supreme Administrative Court.

When, in the mid-1980s, the tension between the administrative legal protection system in Austria and the requirements of the ECHR increased and became all too obvious with the potential consequence of regular condemnations by the European Court of Human Rights, Austrian legislation gave in to the pressure for reform. But instead of a major reform creating a two-stage administrative jurisdiction, the legislator decided to develop only a minimum solution. The 1988 constitutional amendment established Independent Administrative Panels in the provinces which, as decentralised administrative authorities similar to courts, could be appealed to especially in administrative criminal cases. These Panels (below the level of the Supreme Administrative Court) complied with the requirement of a "tribunal" according to Article 6 ECHR. ${ }^{14}$ There was no big debate about the fact that the special procedural provisions for the Independent Administrative Panels were not created by means of a separate Procedural Act but were included in the GAPA.

12 H. Pünder, [in:] Allgemeines Verfahrensrecht, Red. H.-U. Erichson, D. Ehlers, Berlin-New York 2010, p. 420.

13 The Supreme Administrative Court as the only judicial instance was bound by the facts found by the administrative authority and was not entitled to conduct its own investigations; furthermore, there was a ban on innovation, i. e. new facts or evidence could not be presented in the appeal proceedings before the Supreme Administrative Court. The judicial review was in fact limited to a legal control regarding the lawfulness of the administrative decision at the time it was issued. Thus, the review of the Supreme Administrative Court did not comply with the requirements of a "tribunal" according to Article 6 of the ECHR when administrative penalties or administrative matters that concerned "civil rights" within the meaning of Article 6 of the ECHR were subject to appeal (see European Court of Human Rights 23 October 1995, 33/1994/480/562, Gradinger v. Austria; 3 October 2000, 29477/95, Eisenstecken v. Austria).

14 For further details see T. Olechowski, Zur Geschichte der UVS, [in:] Handbuch UVS, Red. A. Larcher, Wien 2012, p. 25; C. Jabloner, Die Entwicklung der Verwaltungsgerichtsbarkeit in Österreich, "Österreichische Juristenzeitung" 1994, p. 329. 
When Austria joined the European Union in 1995, numerous changes in the structure of the administrative organisation had to be implemented, such as the liberalisation of economic sectors previously dominated by the public sector and the creation of numerous regulators and independent supervisory bodies as required by Union law. The excessive workload which was affecting the Supreme Administrative Court as a result of several waves of refugees and many thousands of appeals against asylum rulings as well as the extension of the scope of Article 6 ECHR by Article 47 of the European Charter of Fundamental Rights proved to be decisive steps to the constitutional amendment in 2012, which transformed the system of administrative jurisdiction in Austria drastically. The Independent Administrative Panels in the provinces and 120 special authorities were replaced by Administrative Courts in the provinces and - at federal level - by a Federal Administrative Court and a Federal Finance Court. A remedy against an administrative ruling to an administrative authority as an appeal instance within the administrative hie-rarchy was no longer provided in order to ensure that an appeal against an administrative ruling can immediately be lodged with the Administrative Court of first instance. The Administrative Courts decision can be subject to review by the Supreme Administrative Court in cases of requiring a decision on legal issues of fundamental importance.

Obviously, the GAPA remains the central "hub" to both the administrative judicial procedure and the administrative procedure. ${ }^{15}$

\section{Uniformity of administrative procedure law}

\subsection{The idea of codification}

The Uniformity of procedural law is essential for legal certainty and equality of rights. ${ }^{16}$ This aspect alone would probably not have prompted politicians in 1925 to codify administrative procedural law. The creation of a unified administrative procedural law should also lead to a "radical" simplification of administration, to which the Republic of Austria had even committed itself under international law in the "Geneva Protocols" in order to receive the agreed international financial assistance. ${ }^{17}$ At the same time, the simplification of procedures could only have

15 See down below 5 .

16 In that sense T. Öhlinger, 60 Jahre Verwaltungsverfahrensgesetze..., p. 8.

17 The so-called "Geneva Protocols" were an international treaty concluded between Great Britain, France, Italy, Czechoslovakia and Austria for the purpose of the "economic and financial reconstruction of Austria" (see F.C.G. No. 842/1922). 
a significant impact and bring about a noticeable reduction in administrative costs if the simplified procedure was consistently applied in the vast majority of areas without any exception, in other words: if the uniformity of procedural law was not diluted by a large number of specific procedural rules.

In view of the diversity of administrative matters and also the diversity of administrative authorities, the creation of a single administrative procedure could only be achieved by "limiting it to the essential". In contrast to other procedural laws, such as the Austrian Civil Procedure Code with more than 600 Sections, the GAPA therefore does not regulate every possible procedural nuance or every imaginable procedural detail. The GAPA contains guideline-like procedural standards based on an abstract model of the course of a proceeding from the filing of an application to the decision on costs. ${ }^{18}$ The procedural rules are designed to be sufficiently general and flexible to provide solid procedural conditions for a wide range of administrative matters which nevertheless respect the principles of the rule of law. Moreover, the flexibility of the general provisions of the GAPA is achieved by the fact that they are applied only in a subsidiary manner in individual areas, that means only in cases where no specific regulation is implemented in the substantive laws. ${ }^{19}$ It was a legislative challenge to provide for the subsidiary validity only in those constellations in which this was necessary on the one hand and did not endanger the uniformity of the administrative procedure on the other hand.

The objective of a uniform code of procedure for all administrative procedures is secured in the Austrian Federal Constitution until today. Pursuant to Article 11 $\$ 2$ of the Federal Constitution Act regulations divergent to the GAPA can be made "only when they are requisite for regularization of the matter in hand", in other words: if the specific legal matter makes a special regulation appear obligatory. ${ }^{20}$ This has put a stop to any tendencies towards decodification from the outset and ensured that, in addition to the scope of application of the GAPA, no more procedural rules are created than absolutely necessary. ${ }^{21}$

18 In that sense H. Schäffer, Administrative Procedure..., p. 871(875).

19 For example, according to Section 73 para 1 GAPA, the authorities are obliged to issue a decision on applications without unnecessary delay, but at the latest six months after receiving the application, unless the administrative rules and regulations provide otherwise. If the administrative rules and regulations do not provide otherwise, administrative decisions may be issued both in writing as well as orally (Section $62 \S 1$ GAPA).

20 E.g. Austrian Constitutional Court 23.10.1980, G 38/80, Compendium of Judgments and Most Important Decisions of the Constitutional Court (VfSlg) No. 8945/1980; see also Constitutional Court 3.12.1998, G 213/98, VfSlg 15351/1998.

21 The case law of the Constitutional Court illustrates that the "blocking" of Article $11 \S 2$ of the Austrian Federal Constitution Act really has a practical benefit. For example a two-day period for appeals in asylum matters was considered as an unnecessary deviation from the two-week period for appeal of the GAPA. The legal provision was repealed by the Constitutional Court as unconstitutional (Constitutional Court 24.6.1998, G 31/98, vfSlg 15.218/1998). The 
A similar provision was included in the Austrian Constitution with the 2012 amendment for the Law on Procedures before the Administrative Courts of first instance. According to Article $136 \$ 2 \mathrm{~B}$-VG, special procedural regulations which deviate from the Administrative Court Procedure Act are only permissible "to the extent necessary to organize the matter". The constitutional legislator itself has thus demonstrated that the codification idea of 1925 is still of great importance in 2012. ${ }^{22}$

\subsection{Scope of the GAPA}

The GAPA regulates the procedure for more or less all administrative authorities in Austria. Special procedural laws exist for certain areas, such as the Administrative Penal Act for administrative criminal proceedings, the Agricultural Procedures Act for proceedings before the agricultural authorities and the Civil Service Procedures Act for civil service proceedings. However, in all these procedural laws, the GAPA is again referred to in large parts and only specific features of the substantive law are subject to special procedural rules. ${ }^{23}$ Only the Federal Fiscal Code regulates the tax procedure largely independently of the GAPA. ${ }^{24}$

Administrative procedures in connection with elections (e.g. parliamentary elections, elections to the province parliament or local council, to the Federal President or referendums) are also completely excluded from the scope of the GAPA. ${ }^{25}$ Thus, for example, the procedure for a person's right to vote and to be registered on the electoral roll is not based on the GAPA but on general principles of the rule of law, which are inherent in the administrative procedure laws, i.e. also in the GAPA. ${ }^{26}$ These general legal principles of a rule-of-law procedure are contradicted, for example, by a completely unfounded incriminating decision, because the addressee of the

same fate suffered the statutory exclusion of the suspensive effect for appeals in the plant licensing procedure (Constitutional Court 1.3.2002, G 319/01, VfSlg 16.460/2002).

22 For more details to the Administrative Court Procedure Law see below 5.

23 See Section 24 of the Administrative Penal Act (F.L.G. No. 52/1991 - renotification, last amendend by F.L.G. No. 57/2018), Section 1 of the Agricultural Procedures Act (F.L.G. No. 173/1950 - renotification, last amendend by F.L.G. I No. 189/2013), and Section $1 \S 1$ of the Civil Service Procedures Act (F.L.G. No. 29/1984 - renotification, last amendend by F.L.G. I No. 65/2015). For example, in a civil service proceeding, a decision may be issued, under certain circumstances, without prior investigation and may also be issued only orally or even only by way of access to the file (See Section 9 of the Civil Service Procedures Act).

24 It is only since 2010 that the Federal Fiscal Code applies to all procedures in fiscal matters in Austria, i.e. also concerning provincial and municipal taxes. Until then, the lack of an agreement between the Federal Government and the Provinces prevented the unification of tax procedure law. This is why procedural codes for tax matters existed also at the Province level for a long time.

25 See Article I 33 Z 4 of the Intruductory Law to the laws governing administrative procedure. See Constitutional Court 14.3.1973, B 269/74, VfSlg 7017/1973. 
decision cannot obtain knowledge of the reasons for the decision and, in addition, the legal protection of the Administrative Court against the incriminating act is also decisively impaired. This obligation to state reasons in accordance with the general principles of a rule-of-law procedure was satisfied by a decision if the relevant legal provisions were cited in the decision and the relevant facts could be checked at least in the files. ${ }^{27}$ Of course, the lack of a comprehensive procedural law makes the solution of numerous procedural problems appear uncertain or at least unsatisfactory. For example, the Constitutional Court did not consider it necessary pursuant to general principles of a rule-of-law procedure that an appeal can be lodged against the breach of the duty to issue a decision within the term set by law. ${ }^{28}$ The Constitutional Court also denied the question of whether there is a right of access to the files in electoral matters. ${ }^{29}$ In general, it can be said that the number of procedures only conducted in accordance with general principles of the rule of law tends to decrease. ${ }^{30}$

A very decisive limitation of the scope of the GAPA, which has existed from the outset and has remained unchanged until now, is the fact that the GAPA can only be applied to official procedures which aim to issue a ruling. ${ }^{31}$ The GAPA therefore does not apply to private sector administration matters, to procedures for issuing regulations or to the exercise of direct administrative power and compulsion. The same can be said of examinations (e.g. in the university sector), which serve to evaluate the knowledge of persons in specific fields. ${ }^{32}$ Neither do the so-called simple sovereign administration or actions by real acts fall within the scope of the GAPA. ${ }^{33}$

\section{Characteristics of the GAPA}

Probably the most significant step connected with the codification of the administrative procedure was the fact that it did not only create objective law, but finally guaranteed subjective public rights to the observance of procedural norms to

27 See Constitutional Court 24.11.2003, B 1701/02, VfSlg 17.033/2003.

28 See Constitutional Court 14. 6.1993, B 179/93, VfSIg 13.420/1993.

29 See Constitutional Court 1.3.2013, WI-4/12, VfSlg 19.733/2013.

30 Most recently, in the context of the 2012 constitutional amendment to the Administrative Jurisdiction Act, the scope of application of the GAPA was extended to include proceedings before Austrian embassies abroad (see Supreme Administrative Court 3.5.2018, Ra 2017/19/0609).

31 See D. Kolonovits, G. Muzak, K. Stöger, Grundriss des österreichischen Verwaltungsverfahrensrechts, Wien 2019, pp. 28ss.

32 See Article I \& 3 Z 6 Intruductory Law to the laws governing administrative procedure.

33 See hereto B. Raschauer, Realakte, schlicht hoheitliches Handeln und Säumnisschutz, [in:] Rechtsschutz gegen staatliche Untätigkeit, Red. M. Holoubek, M. Lang, Wien 2011, p. 265. 
which the citizen could refer. As Heinz Schäffer described it accurately, the citizen thus went from being an object to the subject of the proceedings. ${ }^{34}$ The following aspects of the GAPA should be highlighted.

\subsection{Freedom of form and simplified access to justice}

The idea of simplifying the procedure is also reflected in the objective of the legislator of 1925 to facilitate the citizen's access to the administration. Accordingly, the GAPA is characterised by a high degree of freedom of form: unless special provisions stipulate otherwise, applications may be submitted in writing or orally. ${ }^{35}$ If an applicant submits his application to an administrative authority, which is not competent to decide on his application, the authority must forward the application without undue delay to the actually competent authority (or has to refer the applicant to the competent authority at least). The citizen should not suffer any disadvantage from his lack of knowledge of the exact competences of the administrative authorities. ${ }^{36}$ The request initiating proceedings may be modified at any stage of the proceedings. ${ }^{37}$ Even the incorrect specification of remedies does not harm as long as the actual will of the applicant is evident.

The citizen should not necessarily need the support of a lawyer to be able to bring a matter to the administrative body. In fact the authority is obligated to give oral instructions to persons not represented by professional counsel for taking steps in the proceeding. The authority has to instruct such parties to the proceedings ex officio on the legal consequences connected directly with procedural acts or the failure to perform them. ${ }^{38}$ If, for example, an application for a building permit lacks a building plan, the authority may not reject the application, but must inform the applicant of this lack and demand to submit such a document within a certain period of time, whereby the application may only be rejected after the period of time has expired without result. If the defect is rectified in time, the application is deemed to have been originally submitted correctly. ${ }^{39}$ If a building project contradicts construction law regulations, the administrative authority is obliged to draw the applicant's attention to this and the authority has to advise him to modify his application accordingly. Only in case that the applicant refuses to make a modification

34 See H. Schäffer, Das österreichische Verwaltungsverfahren. Eine Kodifikation für Rechtsstaat und moderne Verwaltungsführung, [in:] Problems of Constitutional Development. Essays in Memory of Prof. István Kovács, ed. A. Rácz, Budapest 1993, pp. 189ss.

35 Section $13 \S 1$ GAPA.

36 Section 6 § 1 GAPA.

37 Section 13 § 8 GAPA.

38 Section 13a GAPA.

39 This is a general duty to provide legal information according to Section 13 § 3 GAPA. 
to his project, the authority is entitled to reject the application as a whole. ${ }^{40}$ As the Supreme Administrative Court stated, "excessive formalism is alien to the spirit of the GAPA". This is why no strictly formalistic standard should be applied when interpreting an application. ${ }^{41}$

As any costs of the procedure may also have an effect as a barrier for citizens in their access to the administrative body, the GAPA contains regulations to minimise the cost risks. Each party involved in an administrative proceeding shall bear all its costs incurred, ${ }^{42}$ and the cash expenses arising from the use of external experts shall be borne by the party submitting the request to institute a proceeding. ${ }^{43}$ The costs of obtaining expert opinions are also reduced by the fact that the authority is required to use so-called official experts to clarify important elements of the facts. Official experts are persons with special expertise who work for the administrative authority as an employee and therefore provide expert opinions free of charge. ${ }^{44}$ When giving their opinion in an administrative procedure, official experts are free from instructions. Only in cases where either no official expert of the administrative body with the necessary expertise is available or where the objectivity and impartiality of the official expert is not assured in the specific case, the authority may appoint external experts to give an opinion, whereby higher costs in the procedure arise which have to be reimbursed by the applicant.

\subsection{The principle of ex officio investigation}

In contrast to civil proceedings, in which two private individuals usually face each other in a dispute about a civil law claim, in administrative proceedings the individual citizen faces the state, or more precisely: an administrative authority, which has to ensure compliance with the law and - if the legal requirements are met - has to grant the right a citizen asserted. In order to compensate the factual imbalance between the administrative authority with its legally qualified and professional officials and the citizen, who is often legally unqualified and limited in his financial resources, the administrative procedure according to the concept of the GAPA is dominated by the principle of ex officio investigation. According to Section 37 GAPA, the authority has to ascertain the state of facts relevant for processing an administrative matter (principle of objective truth). This means that the authority is not bound by the submissions of the parties, but has to examine

40 Supreme Administrative Court 23.6.2010, 2009/06/0007.

41 Supreme Administrative Court 25.9.2019, Ra 2019/19/0391.

42 Section 74 § 1 GAPA.

43 Section 76 § 1 GAPA.

44 Section 52 § 1 GAPA. 
and determine the truth of a fact on its own initiative. ${ }^{45}$ In doing so, the authority shall also carry out the procedure in an appropriate, quick, simple and cost-saving manner. ${ }^{46}$ The efficiency requirement coincides with the fact that the principle of immediacy does not apply in the administrative procedure under the GAPA per se, so that the authority can also request or instruct other administrative authorities to carry out individual procedural steps if this is appropriate and reasonable in terms of cost savings. ${ }^{47}$ The comprehensive duty of the authority to conduct an investigation ex officio is counterbalanced by the party's obligation to cooperate, in particular if a matter can only be clarified in cooperation with the party, for example if the authority is unable to obtain knowledge of circumstances exclusively in the sphere of the party. ${ }^{48}$

\subsection{The principle of the right to be heard and free assessment of evidence}

The "fundamental condition of any lawful investigation procedure" 49 is the principle of the right to be heard. According to Section $45 \$ 3 \mathrm{GAPA}$, a party to the proceedings must be given the opportunity to take note of the result of the evidence taken and to comment within a reasonable period of time. This principle is based on the fundamental idea that under the rule of law, a party to the proceedings must be able to present all relevant aspects of the case or at least deliver its opinion on the issue, so that the party can actively participate in its own proceedings. Granting the right to be heard can also have the practical effect that incorrect assumptions made by the authority can be corrected by information provided by the party to the proceedings. Insofar as the facts are not obvious or legally presumed, the authority has to evaluate, in its free judgment, "carefully taking into consideration the result of the investigation", whether a fact is to be assumed as substantiated or not. ${ }^{50}$ In doing so, the authority has to operate conclusively without infringing the general rules of logic. In the assessment of evidence, the authority is not bound by rigid rules of evidence. Any evidence which is appropriate to establishing the relevant facts of the case and which is relevant to the circumstances of the individual case may be taken into consideration. ${ }^{51}$ It is up to the authority to determine what is to be taken as evidence, but it is essential that the evidence in question is likely to contribute to ascertain the facts. Depending on the type and nature of the evi-

45 See e.g. Supreme Administrative Court 27.1.2014, 2012/11/0157.

46 See Section 39 § 2 GAPA.

47 Section 55 § 1 GAPA.

48 See for example Supreme Administrative Court 20.11.2019, Ro 2019/03/0022.

49 In that sense Constitutional Court 7.10.1950, W II-1/50, VfSlg 2038/1950.

50 Section 45 \& 2 GAPA.

51 Principle of unrestricted legal evidence according to Section 46 GAPA. 
dence, its evidential value must be assessed. The GAPA only regulates the "classic" means of proof (documents, witnesses, interrogation of parties, experts and visual inspection by the authority). ${ }^{52}$

\section{The Administrative Court Procedure in the light of the GAPA}

When establishing the procedure before the Administrative Courts of first instance, the legislator intended to keep the changes caused by the Administrative Justice Reform 2012 as low as possible. The legal uncertainty caused by a new procedural law should be minimized. Consequently, although a separate Federal Act on Proceedings of Administrative Courts (PACA) ${ }^{53}$ was created, the content of this Act refers to GAPA for large parts of the procedural law. ${ }^{54}$ The PACA contains special provisions only for genuine administrative court procedural issues. These regulations apply generally, like those of the GAPA, and its general character is guaranteed by the Austrian Federal Constitution. Special procedural provisions in the substantive laws are unconstitutional if their content contradicts the regulations of the PACA and if their content is not absolutely necessary to regulate the subject matter. ${ }^{55}$

The main principles of the GAPA are also shaping the administrative court procedure. For example, the Administrative Courts of first instance also have to conduct their proceedings in accordance with the principle of ex officio investigation. ${ }^{56}$ The Courts have to comply with the obligation to oral instructions (ex officio) about necessary steps in the proceeding and about the legal consequences of these acts (in accordance with Section 13a GAPA) or to observe the rules on representation as provided for in Section 10 GAPA. Even those provisions of the GAPA remained in force (with regard to the administratrative court proceedings) which regulated the decision making of the (former) administrative appeal authorities. The Administrative Courts always have to decide on the merits of the case when the facts of the case have been established or the investigations required

52 See Section 47 ss. GAPA.

53 F.L.G. I No. 33/2013.

54 Section 17 PACA.

55 For example, the Constitutional Court abolished a legal provision as unconstitutional because it generally excluded the suspensive effect of an appeal against a ruling of the Financial Market Authority and there were no convincing reasons why this regulation deviating from the PACA was necessary (See Constitutional Court 2.3.2018, G 257/2017, VfSlg 20.238/2018).

56 Hereto see e.g. Supreme Administrative Court 26.6.2014, Ro 2014/03/0063. 
to establish the facts do not require excessive effort. ${ }^{57}$ If, for example, the authority has wrongly dismissed an application for a building permit, the Administrative Court must, as a result of the appeal, not only quash such a decision but also grant the building permit directly. The purpose of this comprehensive decision-making power of the Administrative Courts is to ensure that the citizen's legal entitlement is granted as quickly and definitively as possible. The goal is to avoid unnecessary procedural delays, such as those that are inevitable when a matter is referred back to the administrative authority to continue the procedure. Even the obligation stipulated in Section 52 of the GAPA, according to which the administrative authority is required to make primary use of the authority's own official experts to clarify technical issues, has been largely extended to the administrative court procedure. $^{58}$

However, the strong dominance of GAPA at the level of the administrative court procedure can also have negative effects in detail. For example, the regulation which states that the applicant has to bear the costs of the opinion of an external expert also applies in the administrative court proceedings. As a result, the applicant of an administrative proceeding must also bear such costs arising in an administrative court proceeding, regardless of the outcome of the appeal, even if he did not file the complaint, but a co-involved party, such as a neighbour in the building permit procedure, who has filed an unsuccessful complaint. ${ }^{59}$ Negative effects were also provoked by the Administrative Courts' decision-making power. The Supreme Administrative Court's jurisdiction leads to a general duty of the Administrative Courts to always decide on the merits of the case and de facto almost excludes the possibility of referring the case back to the administrative authorities for ascertaining further facts. This has opened the way for administrative authorities to carry out its procedure in an all too time-saving and effortless manner, notwithstanding the requirements of the GAPA, because this can be done anyway by the Administrative Courts in case of an appeal. The "delegation" of a lawful conduct of a proceeding "upwards" leads inevitably to overburdening the Administrative Courts. Moreover, the relief of the administrative authorities from a careful conduct of an administrative proceeding was not a goal of the Administrative Justice Reform. The Austrian legislator will have to modify and adjust pro futuro the sensitive relationship between controlled administration and controlling Administrative Courts if the objectives of the Administrative Justice Reform shall be fully achieved.

57 Section 28 § 2 and § 3 PACA; for further details see Supreme Administrative Court 26.6.2014, Ro 2014/03/0063.

58 See Supreme Administrative Court 19.3.2015, Ra 2015/06/0024.

59 According to Section $76 \S 2$ GAPA, the defendant only has to bear the expenses for the expert opinion if he is "at fault" for the (unnecessary) obtaining of the expert opinion. This will only be proven in very rare cases. 


\section{Trends in administrative procedure law}

\subsection{Challenges for administrative procedure law}

The GAPA provides certainly a proven procedure with rule of law standards. In recent decades, however, the extent of public participation and the involvement of environmental organisations and associations in procedures concerning the approval of major infrastructure projects has steadily increased. The proper conduct of such proceedings in accordance with the rule of law has led to a situation where the duration of proceedings has sometimes reached an exorbitant length.

Hydropower plants or wind farms for electricity supply, a further runway for an airport or a tunnel to improve urban traffic are often planned because of an urgent need, whereas residents involved in the proceedings who oppose the projects are usually interested in a very comprehensive and detailed examination, whereby the construction of the infrastructure project cannot begin until the proceedings are completed. ${ }^{60}$ In order to accelerate such procedures significantly, the legislator even passed a Location Development $\mathrm{Act}^{61}$ in 2018, which contains for environmental impact assessments of large-scale projects special procedural rules, such as the possibility to restrict speaking time in hearings or to prohibit an irrelevant objection. ${ }^{62}$ As the phenomenon of procedural delays is not a problem of environmental impact assessments, Section 39 para 3 GAPA provides now in general that the administrative authority may declare the investigation procedure as closed when the case is ready for decision.

Time will tell whether the Location Development Act is in conformity with constitutional and Union law in all respects and whether the new regulation of Section $39 \$ 3$ GAPA can really contribute to accelerate procedures. In any case, both legislative initiatives clearly demonstrate the current challenges to administrative procedure law. The administrative procedure must not only ensure that the rights of all parties involved are properly protected under the rule of law, but also that a decision is reached within a reasonable period of time.

60 The duration of some environmental impact assessment procedures even exceeded five years, from application to issuing of the ruling. Furthermore there has to be taken into account that the administrative procedure is often followed by a judicial appeal against the ruling and a review procedure against the judgment of the Administrative Court.

61 F.L.G. I No. 110/2018.

62 See Section 11ss. of the Location Development Act. 


\subsection{The influence of EU law on the administrative procedure}

Union law also implies high requirements for administrative procedural law. Its influence affects all conceivable areas.

More recently the binding character of declaratory rulings on the necessity of environmental impact assessments has been put to the test from the point of view of Union law, more precisely the "wide" access to justice for the public guaranteed in the Aarhus Convention. The Court of Justice of the European Union stated in its preliminary ruling that declaratory decisions stating that an environmental impact assessment is not necessary concerning a concrete project are not binding on "neighbours" if they could not participate in the procedure for issuing the declaratory decision. In reaction to this preliminary ruling, the Austrian legislator did not grant neighbours and environmental organisations the status of a party in declaratory proceedings, but did grant them the right to appeal against the declaratory decision. ${ }^{63}$

In particular, the principle of effectiveness enshrined in Union law has repeatedly illustrated that the GAPA of 1925 cannot always comply with the current state of Union law. For example, the case-law of the Court of Justice of the European Union derives from the principle of effective judicial protection that, in case of doubt as to the compatibility of national law with Union law, interim measures must also be taken with the effect of granting the applicant (temporarily) a legal position denied to him on the basis of a national law (possibly contrary to Union law). This applies even if national law does not provide for such a measure. However, the possibility provided for in the GAPA ${ }^{64}$ and the PACA ${ }^{65}$ for an appeal against a decision to have suspensive effect presupposes the existence of a ruling and the possibility of suspending the negative effects of a ruling. In the absence of a ruling (especially due to administrative default), the provisional legal protection required by Union law cannot be achieved by regulating the suspensive effect of decisions. As the Austrian legislator has not yet taken any legislative measures, the Administrative Courts must issue interim measures directly on the basis of Union law - if the conditions are met. ${ }^{66}$

Even well established traditions of Austrian administrative procedure law are not sacrosanct from the perspective of Union law. This refers in particular to the $f$ nality of decisions, which can only be disregarded under very limited conditions. ${ }^{67}$

63 Section 3 § 9 Environmental Impact Assessment Act.

64 See Section 64 § 1 GAPA, which still applies to the special case of the municipal sector, where appeals against rulings of the mayor are addressed to the municipal council before appeals against decisions of the municipal council can be logded with an administrative court.

65 Section 13 PACA.

66 Supreme Administrative Court 28.6.2011, 2007/17/0174; 29.10.2014, Ro 2014/04/0069; 5.11.2019, Ra 2019/20/0470.

67 See Sections 68 und 69 GAPA. 
Bearing in mind that the regulations of the GAPA contain a very finality-friendly "concept"68 even in international comparison and, moreover, in Austria an enormous importance is attached to "legal certainty", the preliminary rulings of the Court of Justice of the European Union ${ }^{69}$ about the disregard of the finality of a decision for reasons of Union law surprised a lot.

However, such a withdrawal of a final administrative decision which is contrary to Union law presupposes the cumulative existence of several conditions. The administrative authority must have the competence pursuant to national law to reopen the decision and the decision must have become final only as a result of a judgment of a national court against whose decisions there is no judicial remedy. Third, that judgment must be based on an interpretation of Union law which, in the light of a subsequent judgment of the Court of Justice of the European Union, was incorrect and which was adopted without a question being referred to the European Court for a preliminary ruling. ${ }^{70}$ The initial uncertainty in Austria has probably given way to the perception that the jurisdiction of the Court of Justice of the European Union also gives high priority to the positive effect of finality on legal certainty. ${ }^{71}$

\section{Concluding remarks}

The GAPA has a lot to accomplish nowadays. As a code of procedure, it must not only serve to realise substantive law and create framework conditions that make state actions predictable. The GAPA also has to provide this framework for a wide range of administrative law matters, which are becoming increasingly complex and sophisticated in the course of social and technological development. Finally, it also has to enable a rapid and prompt conduct of proceedings in extensive proceedings with a large number of parties to the proceedings, taking into account all standards of the rule of law principle.

68 See G. Kucsko-Stadlmayer, Merkls Rechtskraftlehre, [in:] Werk und Wirksamkeit, Red. R. Walter, A. Merkl, Wien 1990, p. 135; ebenso T. Öhlinger, „Rechtskraft“ - Die verfassungsrechtliche Dimension: Eine Problemskizze, [in:] Rechtskraft im Verwaltungs- und Abgabenverfahren, Red. M. Holoubek, M. Lang, Wien 2008, p. 27.

69 See EuGH 13.1.2004, Rs. C-453/00, Kühne \& Heitz, Slg. 2004 I-837, Rz 24; 4.10.2012, C-249/11, Byankov.

70 See Constitutional Court 13.12.2012, B 1338/12, vfSlg 19.729/2012; VwGH 29.6.2017, Ra 2017/21/0089; See furthermore in detail C. Ranacher, M. Frischhut, Handbuch Anwendung des EU-Rechts, 2009, p. 379ss.

71 See Supreme Administrative Court 29.6.2017, Ra 2017/21/0089. 
The fact that the GAPA of 1925 met the requirements for almost 100 years with only minor adaptations may seem astonishing, but it shows that the GAPA continues to be an excellent basis for rule-of-law procedures and gives reason for optimism in this context for the future.

\section{Austria}

Austriacka ustawa o ogólnym postępowaniu administracyjnym (AVG) z 1925 r. stworzyła jednolite zasady postępowania mające zastosowanie w dużej liczbie spraw administracyjnych. W ten sposób uproszczono z jednej strony czynności administracji, z drugiej zaś uczyniono je bardziej przewidywalnymi dla uczestników postępowania. Jednolitość postępowania administracyjnego ma w Austrii rangę konstytucyjną: stanowiące odstępstwo od normowań AVG przepisy szczególne tylko wtedy nie są uznawane za sprzeczne z konstytucją, gdy są one absolutnie konieczne do uregulowania przedmiotu postępowania.

Jednocześnie AVG nie reguluje wszystkich aspektów postępowania administracyjnego. Jej przepisy stanowią raczej przewodnie normy procesowe w modelu obejmującym tok postępowania od chwili wniesienia wniosku do rozstrzygnięcia o kosztach. Te przepisy są przy tym na tyle ogólne i elastyczne, że mogą mieć zastosowanie do postępowań w różnych sprawach administracyjnych, zapewniając w ten sposób ich zgodność z zasadą praworządności. Wysoki poziom elastyczności przepisów AVG osiągnięto również dzięki temu, że w niektórych obszarach działania administracji przewidziano wyłącznie ich subsydiarne stosowanie - wchodzą one w grę tylko w tych przypadkach, w których przepisy prawa materialnego nie wprowadzają regulacji szczególnych.

Zakres zastosowania AVG uległ z czasem wydatnemu poszerzeniu: istnieją wprawdzie pojedyncze szczególne ustawy prawa administracyjnego procesowego (jak ustawa o postępowaniu karno-administracyjnym czy ustawa o służbie cywilnej), to jednak przewidziano w nich szeroki zakres odesłań do AVG, regulacji szczególnej poddając tylko specyficzne dla normowanej materii rozwiązania. AVG ma przy tym zastosowanie jedynie do postępowań prowadzonych przez organy administracji publicznej w sprawach podlegających załatwieniu w drodze decyzji administracyjnej. Jej stosowanie nie wchodzi zatem $\mathrm{w}$ grę w sprawach $\mathrm{z}$ zakresu administracji niewładczej, administracji sektora prywatnego, wydawania aktów normatywnych oraz przy podejmowaniu bezpośrednich administracyjnych środków przymusu i nakazu. Podobnie AVG nie ma zastosowania do czynności faktycznych organów administracji oraz do przeprowadzania egzaminów (np. w szkolnictwie wyższym).

W decydujący sposób AVG przyczyniła się do zapewnienia stanu pewności prawnej, ale także przyznała jednostkom prawo domagania się od administracji 
respektowania zasad praworządnego postępowania. Oznacza to, że jednostka z przedmiotu postępowania stała się jego podmiotem. Liczne przepisy AVG ułatwiają obywatelom dostęp do administracji, w tym poprzez zniesienie formalizmu, obniżenie kosztów postępowania oraz nałożenie na organy obowiązków informacyjnych, zorientowanych na zrekompensowanie niższego poziomu świadomości prawnej obywatela. Cel ten znajduje odzwierciedlenie również w jednej z najważniejszych zasad AVG - zasadzie oficjalności, zgodnie z którą organ administracji ma obowiązek z własnej inicjatywy przeprowadzić postępowanie i z urzędu ustalić niezbędny na potrzeby rozstrzygnięcia stan faktyczny odpowiadający prawdzie obiektywnej, nie będąc w tym zakresie związanym wnioskami strony. Organ musi przy tym działać celowo, szybko, prosto i oszczędnie. Z zasadą efektywności postępowania idzie w parze nie mająca bezwzględnego charakteru zasada bezpośredniości, dzięki czemu organ prowadzący postępowanie może zwrócić się do innych organów administracyjnych z prośbą lub wnioskiem o przeprowadzenie poszczególnych czynności procesowych, jeżeli jest to celowe i uzasadnione z punktu widzenia oszczędności kosztów.

W AVG ujęto typową dla każdego praworządnego postępowania zasadę w postaci prawa do wysłuchania, zgodnie z którą stronie postępowania należy zapewnić możliwość zapoznania się z wynikami postępowania dowodowego i zajęcia co do nich stanowiska w rozsądnym terminie. Zasada ta opiera się na podstawowym założeniu, że strona postępowania musi mieć możliwość aktywnego wpływu na przebieg postępowania w jej własnej sprawie i zgłaszania wszelkich związanych z tym wniosków. Zasada swobodnej oceny dowodów z kolei oznacza, że organ ocenia zgromadzony materiał dowodowy „według swobodnej oceny” i nie jest w tym zakresie związany żadnymi sztywnymi regułami dowodowymi.

Istniejący w Austrii od 1875 r. system ochrony prawnej w sprawach administracyjnych z jedynym organem sądowym - Trybunałem Administracyjnym - okazał się sprzeczny z postanowieniami Europejskiej konwencji o ochronie praw człowieka i podstawowych wolności z powodu nazbyt ograniczonej kompetencji kontrolnej tego sądu. W wyniku przeprowadzonej w związku z tym reformy sądownictwa administracyjnego z 2012 r. organy administracyjne, pełniące pierwotnie funkcję organów odwoławczych, zostały zastąpione przez sądy administracyjne pierwszej instancji, od orzeczeń których Trybunał Administracyjnych jest obecnie instancją rewizyjną.

Postępowanie przed sądami administracyjnymi pierwszej instancji reguluje odrębna ustawa o postępowaniu przed sądami administracyjnymi, której jednolitość - tak jak w przypadku AVG - jest gwarantowana konstytucyjnie: szczególne regulacje procesowe mogą odbiegać od ustawy o postępowaniu przed sądami administracyjnymi tylko wtedy, gdy jest to niezbędne dla unormowania przedmiotu postępowania. Obok przepisów typowych dla procedury sądowej ustawa o postępowaniu przed sądami administracyjnymi zawiera szereg odesłań do AVG: $\mathrm{w}$ istocie sądy administracyjne pierwszej instancji prowadzą postępowanie sądowe 
w dużej mierze zgodnie z przepisami AVG. Dotyczy to w szczególności zasady oficjalności. Ponadto sądy administracyjne mają obowiązek zawsze samodzielnie rozstrzygnąć sprawę, jeśli stan faktyczny został ustalony lub środki konieczne do jego ustalenia nie wymagają nadmiernych nakładów. Jeżeli na przykład organ nieprawidłowo odmówił uwzględnienia wniosku o pozwolenie na budowę, sąd administracyjny musi nie tylko uchylić decyzję, ale także samodzielnie wydać pozwolenie. Celem tej kompleksowej (reformatoryjnej) kompetencji orzeczniczej sądów administracyjnych jest zapewnienie możliwości szybkiego i ostatecznego uwzględnienia roszczeń prawnych jednostki, bez zbędnych opóźnień wywołanych przez przekazanie sprawy organowi administracji.

Jednym $\mathrm{z}$ większych dylematów współczesnej procedury administracyjnej jest rozstrzygnięcie kolizji między koniecznością respektowania zasad praworządnego postępowania i potrzebą przeciwdziałania jego przewlekłości. Problem ten jest widoczny zwłaszcza $\mathrm{w}$ postępowaniach $\mathrm{w}$ sprawach o pozwolenia na budowę dla dużych projektów infrastrukturalnych, takich jak elektrownie wodne, autostrady czy farmy wiatrowe, w które zaangażowana jest zwykle duża liczba uczestników postępowania. Jest to istotne tym bardziej, że takie projekty infrastrukturalne są często planowane ze względu na pilne potrzeby. Austriacki prawodawca wprowadził szereg środków prawnych zorientowanych na usprawnienie takich postępowań, jak również - już niezależnie od tego - w celu przeciwdziałania zjawisku przewlekłości postępowania. Skutków ich stosowania w praktyce nie sposób jeszcze przewidzieć, można jednak zakładać, że kwestia długości postępowania zorganizowanego według zasad praworządności nadal będzie mieć ogromne znaczenie w przyszłości.

Innym problemem jest potrzeba dostosowana przepisów AVG do wymagań prawa Unii Europejskiej. Jak się okazało, dla zapewnienia wymaganego przez prawo unijne poziomu ochrony tymczasowej w przypadku naruszenia przepisów tego prawa nie są wystarczające przepisy AVG o skutku zawieszającym decyzji. Również stabilność decyzji, która - zgodnie z AVG - może być podważona tylko wyjątkowo, nie powinna być brana pod uwagę w razie naruszenia prawa unijnego, kiedy spełnione są określone ku temu warunki.

(tłum. Agnieszka Krawczyk)

Peter Chvosta, Dr. jur., Judge and Head of Chamber of the Austrian Federal Administrative Court. Deputy Head of the Registry of the Federal Administrative Court. As a judge of the Asylum Court 2012/2013 involved in the preparations for the establishment of the Federal Administrative Court as part of the 2014 Administrative Court Reform. Lecturer and Examiner at the Federal Academy of Public Administration. Author of numerous publications mainly in the field of administrative and constitutional law, gives lectures on public-law topics in Austria and abroad. 


\section{Chapter IV Croatia}

Dario Đerđa, Ph.D., Full Professor

Head of the Department of Administrative Law

University of Rijeka, Faculty of Law

dariod@pravri.hr

iD https://orcid.org/0000-0002-1095-1155

\section{Stages in the evolution of the law on administrative procedures - from the first codification}

The standardisation of the Croatian administrative procedure began quite early, even from the worldwide perspective. Croatia was part of the Habsburg Monarchy up until the end of World War I, and from the 18th century its administration acted in accordance with the decrees of the Court Chancellery in Vienna that regulated certain administrative areas and certain stages of administrative procedures. Office Instruction from 17 May 1855 was of particular importance for Croatian administration and it was in force in Croatia for over 70 years. This Instruction extensively regulated numerous questions relevant for lawful and proper administration procedures, for instance, the relationship among officials and parties, office management, decision-making and different stages of administrative procedure. ${ }^{1}$ In 1923, specialised Administrative Court in Zagreb started supervising the legality of adjudication in administrative matters. ${ }^{2}$

The procedural rules of Croatian administration were codified rather early. The General Administrative Procedure Act, as federal law in the former Kingdom of Yugoslavia, was compulsory for the Croatian administration from 1931. ${ }^{3}$ This Act

1 D. Medvedović, Geneza novog Zakona o općem upravnom postupku, [in:] Novi Zakon o općem upravnom postupku, eds. D. Foretić and J. Slovinić, Zagreb 2009, pp. 19-22.

2 On the development of administrative disputes in Croatia see D. Medvedović, Upravno sudstvo u Hrvatskoj - prilog za povijesni pregled, [in:] Zbornik odluka Upravnog suda Republike Hrvatske 1977.-2002, ed. M. Kriletić, Zagreb 2004, pp. 1-35.

3 On the standardization of the general administrative procedure in Croatia, see D. Đerđa, Opći upravni postupak u Republici Hrvatskoj, Zagreb 2010, pp. 16-21. 
regulated the rules of procedure for adjudicating in administrative matters and it was in force throughout the existence of the Kingdom of Yugoslavia. It was repealed at the end of World War II and after 11 years new General Administrative Procedure Act was adopted which came into force in 1957. This Act had its basis in legal solutions from the 1930 Act, but numerous procedural institutions were elaborated in more detail. Up until 1991, this Act was amended four times - in 1965, 1977, 1978 and 1986, but its novelties had no influence on the basic procedural provisions. Only a few amendments were aimed at improving certain procedural rules, primarily because of the new technical possibilities, such as electronic processing, microfilm etc.

By declaring its independence in 1991, Croatia took over the Yugoslav Federal Act in its legal system, amending only a few provisions. Such legal regulation of administrative procedures in Croatia was valid until 1 January 2010, when the new General Administrative Procedure Act (further referred to as: GAPA) came into force. GAPA simplifies the administrative procedure in Croatia, and strengthens the values incorporated in Croatian legal tradition, the European Convention for the Protection of Human Rights and Fundamental Freedoms and other important international documents. It is in conformity with the European Union acquis and standards of quality as well as with the modern public administration. GAPA also strengthens the protection of rights and legal interests of citizens in administrative law. Thereby, the rules of administrative procedure in Croatia are now codified under the General Administrative Procedure Act 2009. ${ }^{4}$

\section{The binding force of the law on administrative procedure and the issue of subsidiary application of provisions regarding general administrative procedure}

GAPA prescribes the rules that regulate the process of adjudication in administrative matters. It represents the most important procedural regulation in Croatian administrative law since it obliges all state administrative bodies and agencies, local and regional administrative bodies, as well as legal entities empowered by public-law while performing administrative tasks. ${ }^{5}$ The application of GAPA is closely linked to adjudicating upon administrative matters and to the manner of applying substantive

4 General Administrative Procedure Act, Official Journal no. 47/2009.

5 Article 1 GAPA. 
administrative regulation in order to grant subjective rights or to impose public-law obligations on individuals. Promoting the principle of legality, GAPA entrusts prescribing the preconditions that must be fulfilled while granting rights and imposing obligations on individuals basing on substantive laws and other regulations.

Although GAPA allows the meaning of administrative matter to be determined by laws governing particular administrative areas, this rarely occurs in practice. ${ }^{6}$ Therefore, doubts about the meaning of administrative matter in specific cases are mainly settled by the administrative courts or by the Constitutional Court of the Republic of Croatia. ${ }^{7}$

However, GAPA has a subsidiary application, which means it is applied in all administrative matters unless otherwise is prescribed by law in particular administrative area. By allowing different regulation of certain procedural actions, GAPA enables more efficient and cost-effective mode of administrative actions in particular cases. Furthermore, in these administrative areas there is a need for complementing unregulated GAPA provisions. ${ }^{8}$ Therefore, other laws in the Croatian legal system also govern certain steps of administrative procedures, but only in particular administrative areas. Those are, for example, General Tax Law, Law on Public Procurement, Law on Concessions, Law on Expropriation and Determination of the Compensation, Law on Pension Insurance, Law on Health Care, Law on Foreigners, Arms Act etc. ${ }^{9}$ However, the possibility of derogation from the rules of procedure set

6 Article 2(2) GAPA.

7 There are numerous judgements giving the content to the administrative matter. See for example High Administrative Court judgements: Usž-1969/2015 from 10 December 2015; Usž-3168/2016 from 26 October 2016; Usž-3861/2016 from 15 March 2016; Usž-1912/2017 from 14 June 2017; Usž-1376/2017 from 25 January 2018; Usž-2044/2018 from 24 October 2018, and Constitutional Court of the Republic of Croatia: U-III-665/1995 from 28 April 1999, U-II-722/1995 from 2 April 1997, U-III-261/1996 from 6 April 1998, U-III-168/1996 from 14 January 2000 , etc.

8 For example, GAPA does not prescribe general jurisdiction of an administrative authority, but it refers to a particular law to regulate these issues. Therefore, the Law on Tax Administration, the Law on Protection of the Competition, and the Trademark Act determine the authorities competent to conduct administrative procedures in these administrative areas. Sometimes, the General Administrative Procedure Act itself seeks for its complementation, so for example it prescribes that the initiation of procedures ex officio is determined under particular law, while that particular law also prescribes the initiation of the procedures through public announcement, as well as cases of presumption of adopting the party's request and issuing guarantees for acquiring rights. See the Law on Tax Administration, Official Journal no. 115/2016, Articles 9-12; Law on Protection of the Competition, Official Journal no. 79/2009, 80/2013, Articles 9, 10, 14, and Article 21 Trademark Act, Official Journal no. 14/2019, Article 8, and GAPA, Articles 15(1), 42(1), 43(1), 102(1), 103. See more in D. Đerđa, Z. Pičuljan, Primjena novog Zakona o općem upravnom postupku u posebnim upravnim područjima i upravni ugovori, [in:] Novi Zakon o općem...., p. 102.

9 See General Tax Law, Official Journal no. 115/2016, 106/2018; Law on Public Procurement, Official Journal no. 120/2016; Law on Concessions, Official Journal no. 69/2017; Law on 
down by GAPA is rather limited. Only certain issues of administrative procedure can be regulated differently from what GAPA prescribed and only law can do so, if such regulation is necessary for proceeding in a particular administrative area, and if such proceeding is not contrary to the fundamental provisions and purpose of GAPA. ${ }^{10}$

However, GAPA regulation surpasses the procedure of administrative adjudication. It also regulates the conclusion of administrative contracts and issuing certificates of the facts on which administrative authorities keep official records and for which no official record is kept. Furthermore, it regulates the legal protection from any measure taken by administrative authority or by provider of public service. ${ }^{11}$ GAPA provisions apply mutatis mutandis to any other administrative authority procedures in the area of administrative law that have a direct effect on the rights, obligations or legal interests of the individuals, unless otherwise stipulated. This means that certain provisions, such as provisions on the exemption of officials, delivery of documents, survey of files etc., will be appropriately applied even when the administrative authorities do not conduct the administrative procedure, but they act in non-administrative procedure. ${ }^{12}$

\section{Distinctive institutions and peculiarities of the law on administrative procedures}

Besides regulating the procedure of adjudicating upon an administrative matter and issuing administrative acts, GAPA also regulates administrative actions that affect the rights or obligations of individuals. In order to avoid partiality and arbitrariness in the administrative decision-making process and to protect the rights and legal interests of individuals, rules of administrative procedure have to be detailed. GAPA prescribes specific rules that govern the initiation of the procedure, fact-finding process, as well as the decision-making process. ${ }^{13}$ It also regulates legal remedies - appeal, reopening of the procedure, annulment and revocation of an

Expropriation and Determination of the Compensation, Official Journal no. 74/2014, 69/2017; Law on Pension Insurance, Official Journal no. 157/2013, 151/2014, 33/2015, 93/2015, $120 / 2016,18 / 2018,62 / 2018,115 / 2018$; Law on Health Care, Official Journal no. 100/2018; Law on Foreigners, Official Journal no. 130/2011, 74/2013, 69/2017, 46/2018, 66/2019; Arms Act, Official Journal no. 63/2007, 146/2008, 59/2012, 70/2017, 94/2018.

10 Article 3 GAPA.

11 Articles 150-160 GAPA.

12 Articles 24, 84-95 GAPA.

13 Articles 40-104 GAPA. 
administrative decision, declaring the decision void - and their procedures. ${ }^{14} \mathrm{Fi}-$ nally, it contains rules on the enforcement of the administrative decision, when the party refuses to voluntarily act in accordance with the decision. ${ }^{15}$

Although the rules governing administrative procedure are detailed and precise, GAPA complements them with nine principles that need to be applied in cases of dubious interpretation and filling gaps. Those principles are: the principle of legality, the principle of proportionality in protecting the rights of parties and public interest, the principle of assistance to a party, the principle of finding the material truth, the principle of independence and discretion in evaluation of evidence, the principle of effectiveness and cost efficiency, the principle of access to data and data protection, the principle of the right to a legal remedy and the principle of protection of acquired rights. ${ }^{16}$

Some of those principles are not very common in comparative law. In Croatia, administrative authority has to apply the relevant legal provision on the actual state of facts. The actual state of the facts is also called the "material truth" and means finding all the relevant facts, as they appeared in the real life. ${ }^{17}$ Insisting on the material truth when adjudicating upon administrative matters is justified with the duty of administrative authorities to grant rights or to impose duties on individuals that are prescribed by the law. Administrative decision should not privilege or injure an individual, but grant him such quality and the same number of rights as prescribed by the law. If a greater obligation is imposed on an individual than it is prescribed, this must be regarded as an abuse of administrative power, since according to the administrative law the authority is superior to the individual. On the other hand, if lesser obligation is imposed than is prescribed, this will mean that an administrative authority has failed to protect the public interest, i.e. interest of the society in general. Due to this approach, administrative authorities and individuals have a similar role in finding the true state of facts in the procedure.

One of the peculiarities of the Croatian administrative procedure is the principle of assistance to a party. According to this principle, the official in the administrative procedure has to, ex officio, ensure that the ignorance of any person participating in the procedure does not lead to the loss of their rights to which they are entitled by law. If the official becomes aware of the party's ground for the exercise of a particular right, she will inform the party accordingly, as well as warn him of the consequences of his actions or omissions in the procedure. ${ }^{18}$ This principle implies

14 Articles 105-132 GAPA.

15 Articles 133-149 GAPA.

16 Articles 5-13 GAPA.

17 Article 8 GAPA.

18 Article 7 GAPA. 
that the administrative authority and the party have the same interest in the administrative procedure - lawful adjudication upon the administrative matter. ${ }^{19}$

Electronic communication is becoming a common means of communication in the contemporary world. Although GAPA introduced electronic communication between the administrative authority and the party in the Croatian administrative procedure, this was done in a rather limited manner. The electronic communication may be used only at the request of the party or with the explicit consent of the party. Furthermore, electronic communication may be prescribed by law governing particular administrative area. For example, this is the case with public procurements, where the state insists on finding sufficiently technically and electronically equipped and capacitated contractor. ${ }^{20}$ However, due to insufficient level of IT equipment and capacity of the Croatian population in 2009, the legislator has taken more cautious approach when regulating communication among administrative authorities and parties.

It is also worth mentioning that the administrative decision in Croatia must be made in writing and has strictly regulated content. In addition to the heading, introduction, determination, instruction about the legal remedy, official's signature and the seal of the administrative authority, it must include a very detailed justification. The explanation of an administrative act, i.e. the determination of a decision, is a necessary prerequisite for the protection of the rights of the parties. The explanation is used for the correct interpretation of the decision, it establishes the principle of lawfulness in decision-making, and it facilitates control over the legality of the decisions. ${ }^{21}$ It is very important part of an administrative act, and it has attracted attention in Croatian administrative practice for a long time. ${ }^{22}$ The explanation should include: a brief statement of the party's requests, state of the facts, decisive reasons for the evaluation of evidence, reasons why certain requests of the party were not

19 See more in Ž. Dupelj, Z. Turčić, Komentar Zakona o općem upravnom postupku, Zagreb 2000, p. 67 and I. Borković, Upravno pravo, Zagreb 2002, p. 407.

20 Articles 75 (1, 2), 94 GAPA. See also the Law on the Public Procurement, Official Journal no. 120/2016, Articles 59-73.

21 I. Borković, Upravno..., p. 455; I. Krbek, Upravni akt, [in:] Hrestomatija upravnog prava, ed. D. Medvedović, Zagreb 2003, pp. 39-40.

22 The case law also insists on providing the reasoning for the decision and states that explanation describes whether the administrative authority was guided by the principle of legality and whether it conducted the administrative procedure in such a manner. From this, it can also be determined whether a party was able to adequately protect its rights and legal interests during the decision-making process. The Constitutional court emphasised that failure to state the reasons for adjudication violates the right of equality before - law. A party that does not know the reasons for rejecting its application in the administrative procedure is in an unequal position with those who know the reasons and therefore cannot properly protect its rights or effectively exercise the constitutionally guaranteed right to legal protection. Constitutional Court of the Republic of Croatia U-I-248/94 from 13 November 1996, and U-III-419/98 from 12 July 2001. 
upheld, reasons for the conclusion reached in the course of the procedure and regulations on which the case was adjudicated..$^{23}$ Regardless of whether the party's request is accepted or not, and regardless of the urgency in adjudicating upon the administrative matter, any administrative decision in Croatia must be provided with a detailed explanation of the factual and legal reasons for rendering such a decision. ${ }^{24}$

In procedures initiated at the request of a party, an administrative decision must be made within the time limit prescribed by law. However, the law governing a particular administrative area first sets a deadline. Otherwise, in cases of direct adjudication, i.e. if the official has the all necessary evidences at the initiation stage, he is obligated to decide no later than 30 days from the day of duly fulfilling the application. If the investigatory procedure is conducted, the official is obliged to render a decision within 60 days at the latest. If the official does not render a decision or serve it upon the party within the set deadline, the party is entitled to lodge an appeal or to initiate an administrative dispute and thereby protect his/her rights from the "administrative silence". 25

Finally, in order to contribute to the effectiveness and to the cost efficiency, in the second instance procedure the appellate body is obliged to resolve the administrative matter by itself, if it finds the appeal to be justified and the contested decision unlawful. In accordance with GAPA, appellate authority has to adjudicate the administrative matter itself and not return it to the first-instance authority for a repeated procedure. The exception is made only if, with regard to the nature of the administrative matter, it is necessary for the first-instance authority to adjudicate the administrative matter by itself. Only in this case the second-instance body is allowed to refer the case back to the first-instance body for a repeated procedure. ${ }^{26}$

\section{The relation between legal institutions on administrative procedures and the judicial review model}

In Croatia, the judicial review of the legality of administrative decisions and other actions taken by the administrative authority is ensured in the administrative dispute. Administrative courts provide for protection of the rights and legal interests

23 B. Gagro, Drugostupanjski upravni postupak - zapažanja Upravnog suda u odnosu na primjenu prijašnjeg Zakona o općem upravnom postupku, [in:] Primjena novog Zakona o općem upravnom postupku u praksi, ed. M. Kuzmić, A. Šumelj, Zagreb 2010, p. 94; P. Krijan, Komentar Zakona o općem upravnom postupku, Zagreb 2004, pp. 293-294.

24 Articles $98(1,5)$ GAPA.

25 Article 101 GAPA.

26 Article 117 GAPA. 
of individuals that have been violated in the area of administrative law. ${ }^{27}$ The administrative dispute in Croatia is regulated by the Law on the Administrative Disputes $2010 .{ }^{28}$ This Law was enacted shortly after GAPA. It therefore shares the main ideas and concepts with GAPA.

Some institutes prescribed by GAPA can be used in the course of the administrative dispute. Therefore, close connection between these laws can be noticed. Although the Law on Administrative Dispute does not contain a legal remedy that enables administrative authority to annul or amend its decision in the administrative dispute, the respondent, which is always an administrative authority, can use the legal remedy prescribed by GAPA - annulment or revocation of an unlawful decision - and issue a new decision, as the claimant suggested in the claim. This is a way of tacitly acknowledging the claim, in which case the dispute will be terminated. ${ }^{29}$

It is important to emphasise that the aim and objective of the Law on Administrative Dispute is to achieve administrative justice as soon as possible. For this reason, the administrative courts were given the power and the duty to establish the facts of the case and gather evidence, and in principle to conduct an oral hearing. The most important duty of the courts - of first-instance, but also of High Administrative Court - is to decide on the disputed administrative matter, if they find the contested administrative decision unlawful. In such cases, the court has to annul the contested decision, but also decide on the rights, duties or legal interests of the claimant. Therefore, in most cases in Croatia the administrative courts have to decide the dispute in the manner of full jurisdiction. However, in numerous cases the judges prefer to use the cassation power rather than to decide on the merits, as they do not feel competent to adjudicate upon a specific administrative matter by themselves. In addition, fact-finding by the High Administrative Court is particularly difficult in some cases, given that this Court is situated in Zagreb. Therefore, in practice the fact-finding procedure could be costly and inefficient, affecting the High Administrative Court's duty to decide on any disputed administrative matter.

27 There are four administrative courts of first instance and the High Administrative Court as a court of second instance in Croatia.

28 Law on Administrative Disputes, Official Journal no. 20/2010, 143/2012, 152/2014, 94/2016, 29/2017.

29 Law on Administrative Disputes, Article 43. 


\section{Influence of the Austrian codification idea on the form of contemporary legal solutions}

Austrian heritage left a strong influence on the Croatian administrative law. The application of the Austrian legal regime until the end of World War I was not the only reason. In addition, many Croatian lawyers studied law in Vienna at the time. Therefore, Austrian law, and especially Administrative Procedure Act 1925, had strong influence on the Croatian regulation of administrative procedure even until the recent days. The Yugoslav laws governing the general administrative procedure of 1931 and 1957, reflected the structure and the most important institutions from the Austrian paragon. For example, the principle of legality, the principle of effectiveness and cost efficiency, the principle of discretion in evaluation of evidence, the parties' right to be heard and ensuring impartiality by exemption of an official were all taken from Austrian law. In addition, certain concepts were also followed in the facts-finding procedure, considering any evidence, using oral hearing as non-mandatory etc. Legal remedies, such as appeal against the decision and reopening of procedure, were also taken from the Austrian model..$^{30}$

However, GAPA 2009 made some deviations from the Austrian paragon, but it did so more in the structure than in its content. It rearranged the former provisions regarding the way of following procedural steps. It did not depart from the traditional concept of the fundamental powers of an administrative authority and from the basic procedural rights of parties, nor from the legal remedies necessary for ensuring legality of administrative decisions and other measures. Therefore, the strong influence of Austrian heritage in administrative procedure regulation is still present in Croatia.

\section{The impact of the European law on national legislature and judicature}

GAPA 2009 was adopted in the process of Europeanization of the Croatian law and during the period of Croatian accession to the European Union. At the time, Croatian legal system was strongly influenced by the principles of European Administrative Space, which give rise to the different understanding of the role

30 N. Stjepanović, Zakoni o upravnom postupku Austrije, SAD, Mađarske i Španije, Beograd 1960, pp. VII-VIII. 
of public administration and a modern perception of its activities. The main objective of the modernization and Europeanization of public administration was to enable the effective implementation of the law, to strengthen the acquisition and protection of citizens' rights, to stimulate economic growth and to provide better public services. In order to achieve these goals, it was necessary to improve General Administrative Procedure Act 1991 that was not amended for nearly 20 years. More than 50 years after its enactment, the circumstances in which it needs to be applied have changed significantly. The new social and political context at the beginning of the 21 st century required the modernization of legal regulation of administrative procedure. ${ }^{31}$ Although the former Act was of good quality and well structured, with many positive aspects, it also had certain weaknesses. ${ }^{32}$ Complex and lengthy administrative procedures, formalism, high costs, but also corruption in the administration, have proven to be major problems in adjudicating upon administrative matters. At the same time, the European theory of administrative action has evolved significantly, developing new European standards of public administration and good administrative practice in Member States of the European Union. ${ }^{33}$ Therefore, in 2009, new GAPA was drafted, in order to simplify administrative procedures, protect the principle of legality, meet the challenges of strengthening information and communication technologies, and incorporate new European public administration standards and good administrative practice into the Croatian legal system. This Act came into force on 1 January 2010, introducing a new procedural framework for conducting administrative procedures and protecting legality in adjudicating administrative matters.

31 In the European Commission's 2005 Progress Report on the Republic of Croatia, European Commission, Croatia 2005 progress report (COM (2005) 561 final), Brussels, 2005, it was emphasized that GAPA 1991 was not completely harmonized with common European standards of the rule of law.

32 The particular advantages of GAPA 1991 were long-time application, lot of procedural protection mechanisms, the right of appeal, insisting on the principle of legality, balance in protecting public and private interest, finding the material truth, administrative authority duty to assist the party in the process, etc. This Act contributed significantly to the rule of law and to the lawfulness in adjudicating upon administrative matters. See more in D. Medvedović, Geneza novog Zakona..., pp. 24-25.

33 See S. Cassese, European Administrative Proceedings, "Law and Contemporary Problems" 2004, vol. 68, no. 1, pp. 21-36; M. Chiti, Forms of European Administrative Action, ibidem, pp. 37-60; idem, Administrative Proceedings Involving European Agencies, ibidem, pp. 197218; G. della Cannea, The European Union's Mixed Administrative Proceedings, ibidem, pp. 197-218, etc. 


\section{Openness to innovation - is the goal of modernization visible in the activities of the legislature?}

GAPA reflects good balance between the traditional administrative values formerly developed in Croatia and contemporary institutes that must ensure the lawful, effective and cost-efficient exercise of public tasks. A well-structured administrative procedure with precisely prescribed administrative powers and mechanisms for protecting the rights of a party, such as the exemption of an official, right to be heard, the oral hearing procedure, the rationale for an administrative decision, has been part of the Croatian legal system even from 1931, or at least from 1957. Today, these legal institutes are complemented with the modern ones, such as electronic communication, provision of information and data protection, presumptions for accepting the party's request (in certain cases), complaint as an effective means of legal protection, principle of proportionality in the decision-making process and in the enforcement of administrative decisions, administrative contracts, legal protection of the beneficiary of the public service, etc. These institutes help in solving contemporary complex relations between the public administration and the individual. ${ }^{34}$

GAPA aims to make administrative procedure more flexible and transparent, without weakening the protection of the individuals' rights. It increases the professionalism in dealing with administrative matters, strengthens ethical principles and the rule of law in administrative service, and enables reliable, open, transparent, efficient, cost efficient, fair and citizens-orientated public administration. Therefore, it is worth emphasising that GAPA reconciles traditional values in conducting administrative procedure with contemporary standards of public administration. The fact that this Act has not been changed for over than 10 years, which is an extremely rare example in the Croatian legal system, confirms the quality of its content.

\section{Codification of administrative procedure and decodifying trends}

Enactment of GAPA 2009, initiated decodifying processes in numerous special administrative areas. By 2009, many laws governing particular administrative areas or institutes often prescribed several or more procedural provisions that had 
to be applied in administrative adjudication. Some of these provisions differed from the GAPA regulation, i.e. some laws excluded the right to appeal or shortened the deadlines for filing an appeal or restricted the use of some evidentiary means etc. Some governed the entire stages of the procedure, such as the General Tax Law, meaning that GAPA could be applied only to few procedural institutions. ${ }^{35}$ Major deviations from GAPA were made in the laws relating to pension insurance, health insurance, rights of Croatian veterans, the civil servants system, access to information and data protection, asylum, urban planning and construction, expropriation, maritime domain, inspections' supervision, industrial design, patents, trademark, public procurement, concessions and competition. Over the years, such legal regulation led to legal uncertainty, slowed down the decision-making process, brought numerous appeals and requests for judicial protection, and caused a loss of trust in public administration. ${ }^{36}$ GAPA 2009 contains numerous provisions that have influenced the standardization of certain issues in particular administrative areas. ${ }^{37}$

From 2010 onwards, in the so-called "streamlining" procedure of administrative procedures in Croatia, special procedural rules have been significantly reduced and harmonised with the GAPA. The uniformity of administrative procedure contributes to legal certainty and the rule of law, reducing costs, suppressing arbitrary treatment and increasing the efficiency and cost effectiveness of public administration procedures.

\section{Codification of administrative procedure and practice}

Most of the GAPA provisions, after 10 years of application, fit their purpose in practice. Of course, administrative actions need to be continuously improved, and methods of improving administrative activities need to be developed outside the

35 B. Ljubanović in 2006 conducted a research and concluded that in Croatia there were more than 70 laws containing special procedural provisions departing from the GAPA. B. Ljubanović, Posebni upravni postupci u Hrvatskoj, "Hrvatska javna uprava" 2006, vol. 6, no. 3, pp. 5-22; idem, Posebnosti poreznog i carinskog upravnog postupka naspram novog općeg upravnog postupka, [in:] Aktualnosti upravnog sudovanja i upravne prakse - 2009, eds. M. Kuzmić and J. Hercigonja, Zagreb 2009, p. 186.

36 See D. Medvedović, Geneza novog Zakona..., pp. 25-26. He emphasises that the causes for such discrepancies are different, but lots of them are caused by poor implementation of European Union directives, i.e. under the pressure from various international institutions and their experts.

37 Vidi B. Ljubanović, Novi zakon o općem upravnom postupku i posebni upravni postupci, “Hrvatska javna uprava” 2010, vol. 10, no. 2, p. 320. 
legislative process. For that purpose, Croatia has to insist on the expertise of officials that will be used in their everyday work, especially in administrative adjudication processes. Unnecessary procedural provisions and mechanisms contained in laws governing particular administrative areas must be steadily reduced. Deadlines should be respected, especially instructive ones, in order to quickly resolve administrative matters. Electronic communication and electronic delivery should be encouraged, as a fast and inexpensive means of communication. Finally, an effective mechanism for monitoring GAPA implementation should be developed, to ensure that the effects of the law are reviewed at the highest quality level.

Unfortunately, some of the institutions prescribed in GAPA did not justify the reasons for their inclusion in the legal text. For instance, since more than ten years of its implementation, the so-called "single administrative place" has not been developed at all. ${ }^{38}$ Today, the Act on the State Administration System prescribes the establishment of the single administrative place but none has been organised yet. ${ }^{39}$ Another underused institute prescribed by the GAPA is the administrative contract. It is a special type of contract concluded between an administrative authority and an individual on the performance of rights and duties established by an administrative decision. This type of contract can be concluded only if the law anticipates it. ${ }^{40}$ To date, administrative contracts have been prescribed only in the General Tax Law, the Concessions Act, the Hunting Act and the Law on Housing in Assisted Areas, all of which have been adopted within the last two years. ${ }^{41}$ However, the inclusion of administrative contracts in other administrative areas suitable for its frequent usage, as it is the case in the public procurement area, should have been done long ago. ${ }^{42}$ Therefore, more efforts are necessary in order to bring some of the underused GAPA institutions into everyday life.

38 Articles 22 GAPA, provides that if more than one administrative or other procedure is required for the exercise of a party's right, the party should be allowed to submit, in a single administrative place all requests, which shall to be submitted ex officio without delay to the competent public authorities. It also stipulates that parties and other interested persons may obtain information, advice and other assistance within the scope of competence of an administrative authority in a single administrative place.

39 Law on the System of the State Administration, Official Journal no. 66/2019, art. 20.

40 GAPA also stipulates conditions for concluding administrative contract, the reasons for its nullity, the admissibility of its modification and termination, and finally, legal protection in relation to the administrative contract. Articles 150-154 GAPA.

41 General Tax Law, Official Journal no. 115/2016, 106/2018, Articles 101-103; Law on Concessions, Official Journal no. 69/2017, Articles 3 (3-5, 7); Hunting Act, Official Journal no. 99/2018, Articles 24-29 and Law on Housing in Assisted Areas, Official Journal no. 106/2018, Articles 18(2), 34(1-2).

42 Public procurement contract in current legal regulation of the Public Procurement Act, Official Journal no. 120/2016, Articles 312, cannot be regarded as an administrative contract. 


\section{Successes and failures - what has not been achieved?}

GAPA should be considered as comprehensive law regulating all activities of administrative authorities in the administrative law area. Its content goes beyond the regulation of administrative procedures and prescribes some institutions which are usually considered outside this procedure. This is the case with the enforcement of the administrative decision, the conclusion of an administrative contract, issuing of the certificates regarding the facts in and out of the official evidence and legal protection against measures issued by administrative authorities and public service providers. Therefore, it represents the main procedural act that has to be followed by an administrative authority, whenever such authority decides or takes measures in the field of administrative law.

In the future, Croatia must take certain steps to ensure the legality of the application of GAPA and thus the legality of all administrative authorities' actions taken in the area of administrative law. It is very important to insist on the appropriate professional legal knowledge that officials must acquire in high-level educational institutions, as well as in specialised life-long learning programs. However, these goals cannot be prescribed by GAPA, since they are part of the legislation on civil servants. Therefore, Croatia has to adopt measures in the comprehensive public law system in order to ensure lawful conduct of administrative procedures as well as speedy and fair adjudication.

\section{General conclusions and comments on the prospects for the development of the law on administrative procedure}

From the current point of view, it could be emphasised that GAPA was largely responsive to the challenges that existed at the time of its adoption. It simplified the conduct of administrative procedures and enabled officials to be more creative when undertaking procedural actions. At the same time, it insisted on the legality of the administrative authorities' work. It established procedural mechanisms to expedite administrative adjudication, as well as various models of legal protection of individual's rights. Therefore, GAPA can, in principle, be considered very good law, which does not raise urgent issues that would require longterm improvements in its regulation. Finally, while Croatia has a well-structured procedural framework for conducting administrative procedures that reflects 
both tradition and modernisation, in order to achieve the values of administration in the service of the citizens, it must focus on the systematic education and professional development of officials, who contribute the most to the correct implementation of GAPA in practice.

\section{Chorwacja}

Niektóre aspekty chorwackiego postępowania administracyjnego były przedmiotem unormowań już w czasach Monarchii Habsburskiej, niemniej całość procedury została po raz pierwszy skodyfikowana w Królestwie Jugosławii w 1930 r. Dokonano tego ustawą o ogólnym postępowaniu administracyjnym. Wkrótce po drugiej wojnie światowej została ona uchylona. W 1957 r. weszła w życie bardziej szczegółowa ustawa regulująca procedurę administracyjną. Została ona recypowana, z niewielkimi zmianami, przez Chorwację po ogłoszeniu przez nią niepodległości i obowiązywała do końca 2009 r. Obecnie postępowanie administracyjne w tym kraju jest uregulowane ustawą o ogólnym postępowaniu administracyjnym z 2009 r. (the General Administrative Act - GAPA), która weszła w życie 1 stycznia $2010 \mathrm{r}$.

Przepisy GAPA określają zasady dotyczące procesu orzekania w sprawach administracyjnych. Wiążą one wszystkie organy administracji państwowej i agencje, organy lokalnych i regionalnych jednostek samorządu terytorialnego, a także osoby prawne upoważnione przez organy publicznoprawne do wykonywania zadań zleconych z zakresu administracji. Ustawa ma charakter subsydiarny, co oznacza, że stosuje się ją we wszystkich sprawach administracyjnych, chyba że odrębna ustawa stanowi inaczej. Przewidując możliwość regulacji danych zagadnień proceduralnych przez przepisy szczególne, GAPA stoi na straży szeroko rozumianej ekonomiki procesowej. Jednak unormowanie to nie ogranicza się wyłącznie do procesu orzekania. Ustawa reguluje także zawieranie umów administracyjnych i wydawanie zaświadczeń o faktach, co do których organy administracyjne prowadzą urzędową dokumentację oraz co do których dokumentacja nie jest prowadzona. Ponadto przewiduje ochronę prawną w sprawach środków podjętych przez organy administracyjne i pozostałe podmioty wykonujące zadania publiczne. Przepisy GAPA stosuje się odpowiednio do wszelkich innych działań organów administracji w sferze prawa administracyjnego, które mają bezpośredni wpływ na prawa, obowiązki lub interesy prawne jednostki, chyba że zastrzeżono inaczej.

Przepisy GAPA określają szczegółowo zasady dotyczące wszczęcia postępowania, reżimu ustalania faktów, a także podejmowania decyzji. Regulują również zwykłe i nadzwyczajne tryby wzruszenia zapadłego rozstrzygnięcia. Ustawa zawiera też przepisy odnoszące się do przymusowego wykonania decyzji administracyjnej, gdy strona odmawia dobrowolnego podporządkowania się jej. Choć reguły 
postępowania administracyjnego w Chorwacji są precyzyjne, GAPA uzupełnia je dziewięcioma zasadami, które należy stosować w przypadkach wystąpienia wątpliwości interpretacyjnych i istnienia luk, tj. zasadami: legalności, proporcjonalności $\mathrm{w}$ ochronie praw stron i interesu publicznego, udzielania pomocy stronom, prawdy materialnej, swobodnej oceny dowodów, ekonomiki procesowej i oszczędności kosztów, dostępu do danych i ich ochrony, prawa do środka zaskarżenia i ochrony praw nabytych.

Autor zwraca uwagę, że konstrukcja GAPA odzwierciedla stan równowagi między tradycyjnymi wartościami administracyjnymi utrwalonymi od lat w Chorwacji, a współczesnymi instytucjami, których celem jest zapewnienie zgodnego z prawem, skutecznego i sprawnego wykonywania zadań publicznych. Dobrze ukształtowana procedura, $\mathrm{z}$ dokładnie określonymi uprawnieniami administracji i mechanizmami ochrony praw strony, takimi jak wyłączenie urzędnika, prawo do bycia wysłuchanym, tryb rozprawy ustnej czy uzasadnienie decyzji administracyjnej, są częścią chorwackiego systemu prawnego co najmniej od 1957 bądź nawet od 1931 r. Dawne rozwiązania prawne są systematycznie uzupełniane nowymi, takimi jak komunikacja elektroniczna, udzielanie informacji i ochrony danych, domniemanie - w niektórych przypadkach - przyjęcia wniosku strony, zachowanie proporcjonalności w procesie decyzyjnym i wykonywaniu decyzji, umowy administracyjne lub ochrona prawna beneficjenta usług publicznych.

Twórcy GAPA dążyli do tego, aby procedura administracyjna była bardziej elastyczna i przejrzysta, przy zapewnieniu jednostce ochrony jej praw. Ustawa ta jest ukierunkowana na wzmocnienie profesjonalizmu w załatwianiu spraw administracyjnych, praworządności w administracji oraz kreowanie niezawodnej, otwartej, wydajnej, uczciwej i respektującej interesy obywateli administracji publicznej. Ponadto GAPA upraszcza postępowanie administracyjne i kultywuje wartości zakorzenione w chorwackiej tradycji prawnej, Europejskiej konwencji o ochronie praw człowieka i podstawowych wolności oraz innych aktach prawa europejskiego i międzynarodowego. Ustawa ta nie była zmieniana od ponad 10 lat, co jest niezwykle rzadkim przypadkiem w chorwackim systemie prawnym, potwierdzającym jej rangę.

Niestety, nie wszystkie instytucje prawne uregulowane w GAPA zdały egzamin w praktyce. Z negatywną oceną spotkało się np. funkcjonowanie systemu ,jednego punktu kontaktu z administracją”, znanego gdzie indziej jako reżim „jednego okienka”, który w zamyśle miał uprościć składanie wniosków przez obywateli i komunikację z organami administracyjnymi, jak również korzystanie $\mathrm{z}$ formy umowy administracyjnej. Niezbędne są zatem - w przekonaniu autora - dalsze wysiłki $\mathrm{w}$ celu upowszechnienia niektórych $\mathrm{z}$ niedocenionych dotychczas lub mających marginalne znaczenie instytucji GAPA. Podkreśla on również, że w przyszłości władze Chorwacji muszą podjąć pewne kroki w celu zapewnienia prawidłowego stosowania GAPA, a tym samym zgodności z prawem działań organów administracyjnych. Terminy, w szczególności instrukcyjne, powinny być skrupulatnie 
przestrzegane, w celu sprawnego rozstrzygania spraw administracyjnych. Należy również - w jego ocenie - upowszechnić komunikację elektroniczną wraz z taką formą doręczeń, jako szybkiego i niedrogiego środka kontaktu. Potrzebny jest wreszcie efektywny mechanizm monitorowania wdrażania GAPA, zapewniający dokładną obserwację skutków obowiązywania ustawy. Równie ważne jest pogłębianie wiedzy kadry urzędniczej i to zarówno w instytucjach szkolnictwa wyższego, jak i w specjalistycznych programach ustawicznego kształcenia. Wytyczanie tych celów należy do ustawodawstwa w przedmiocie służby cywilnej. W związku z tym konieczne jest kompleksowe podejście do wskazanego problemu i operowanie adekwatnymi do jego charakteru środkami.

(tłum. Monika Kmieciak)

Dario Đerđa, Ph.D., Full Professor of Administrative Law, the head of the Department of Administrative Law and the Vice-Dean at the University of Rijeka, Faculty of Law. Author of more than 100 scientific and professional articles and papers, as well as monographs on General Administrative Procedure in the Republic of Croatia, Basics of European Administrative Law, Administrative Procedure and Administrative Dispute. He is the author of chapters in several books published by domestic and foreign publishers and a co-author of the Manual for the Implementation of the Law on the Administrative Disputes. In 2013, he received the state legal award Jadranko Crnić as the author of the book representing a significant contribution to the legal profession for 2012. He took part as a presenter and a moderator at numerous international and domestic scientific and professional conferences. As a member of the working groups he drafted several laws in the area of the administrative law, i.e. the General Administrative Procedure Act and the Law on Administrative Disputes. 



\section{Chapter V \\ Czech Republic}

Kateřina Frumarová, Doc. JUDr., Ph.D.

Head of the Department of Administrative and Financial Law

Faculty of Law, Palacky University in Olomouc

katerina.frumarova@upol.cz

iD https://orcid.org/0000-0001-5886-1645

\section{Development of legal regulation of administrative proceedings}

After the establishment of an independent Czechoslovakia in 1918, it took 10 years to adopt the first separate legal regulation on administrative proceedings. On the basis of the so-called Reception Act, ${ }^{1}$ the laws at the time of the Austro-Hungarian Empire remained provisionally in force. Thus, the duality of law was established, with Austrian law in the Czech lands and Hungarian law in Slovakia. ${ }^{2}$ At that time, the legal regulation on the administrative proceedings was fragmented and incomplete, relying heavily on the Austrian judicial case-law and practice as well as on the decision-making activities of the newly established Supreme Administrative Court. The Supreme Administrative Court was established right after the establishment of the Republic in 1918 and E. Hácha ${ }^{3}$ also proves its importance by stating: "The importance of the Administrative Tribunal lies in its very existence. The mere fact that administrative acts are subject to judicial review encourages caution and stops administrative arbitrariness".

1 Act No. 11/1918 Collection of Laws (hereafter: Coll), on the Establishment of an Independent Czechoslovak State.

2 In more detail F. Weyr, Československé právo správní: část obecná (organisace veřejné správy a řizenísprávní), Brno 1922, p. 10.

3 Emil Hácha was one of the most significant lawyers of Czechoslovakia and from 1925 to 1938 he was the chairman of the Supreme Administrative Court. From 1938 to 1945 he was the president of the Czechoslovak Republic.

4 E. Hácha, Nejvyšši správní soud. Vzpomínka na jeho zřízení a jeho dnešní stav, "Právník" 1928, pp. 587-593. 
The first separate regulation of administrative proceedings was adopted in 1928. It was the Government Decree No. 8/1928 Coll., on proceedings in matters belonging to the competence of political authorities (administrative proceedings). This legislation was in the form of "only" a sub-legal regulation (not a law), it was issued by the government (i.e. the executive body), not by Parliament. It was essentially based on and followed up on the existing decision-making practice of administrative authorities and courts, especially of the Supreme Administrative Court. This was the first codification of administrative proceedings in Czechoslovakia. It should be stressed, however, that not all kinds of administrative proceedings were affected by this legal regulation. For example, proceedings before tax authorities or proceedings before self-governing authorities had special law regulations. ${ }^{5}$

The Code of Administrative Procedure also did not apply to proceedings in matters of civil service or criminal administrative proceedings. Special legislation was maintained for a number of areas of state administration (the Code did not apply to proceedings before all administrative authorities); that is why the administrative doctrine of the time pointed out the inadequacy of this codification. ${ }^{6}$ František Weyr then referred to the Austrian legislation of 1925 as a more appropriate inspiration. ${ }^{7}$ It is important to point out that this regulation governed only the administrative procedure, i.e. the procedure which resulted in an administrative decision. It did not regulate other procedures of public authorities (e.g. the conclusion of public law contracts, etc.).

The unusual trend of administrative proceedings being regulated by a subordinate act, not by a law, continued. The other two codifications of the administrative proceedings were again government orders. Specifically, it was the Government Decree No. 20/1955 Coll., on Administrative Proceedings (the Administrative Procedure Code), and then the Government Decree No. 91/1960 Coll., on Administrative Proceedings. Both of these regulations were influenced by the era at which they were adopted. This meant that they reflected the ideology of communism and socialism. Most critically, the government decree of 1960 should be viewed nowadays. With regard to the ruling ideology, many classic institutions of administrative proceedings have been completely removed from the regulation as a "bourgeois survival" (e.g. deadlines, eligibility of participants, bias, evidence, and others). ${ }^{8}$

However, such a regulation of the administrative procedure seemed to be increasingly inadequate and therefore the first statutory regulation was finally adopted, namely Act No. 71/1967 Coll., on Administrative Procedure (the Administrative Procedure Code). This Code by its quality followed the codification of 1928

5 F. Weyr, Správní rád, Brno 1930, p. 19.

6 See J. Hoetzel, Řizení správní. Slovník veřejného práva československého, Praha 2000, p. 921.

7 F. Weyr, Správní..., p. 19.

8 Collective work, Historický vývoj právní úpravy správního řizení a dalších postupů ve veřejné správě v českých zemích (1918-2005), Olomouc 2007, p. 293. 
and compared to the government regulation of 1960 it was much more sophisticated and detailed. Nevertheless, it still applied only to classic administrative proceedings, it did not regulate other public administration procedures. ${ }^{9}$ This Act was also conceived as a subsidiary procedural regulation, i.e. it should have been applied if the matter was not regulated in a separate legal regulation. Thus, the fragmentation of the legal regulation of administrative proceedings continued, where, besides the Code of Administrative Procedure, there were special legal regulations in relation to individual branches of public administration. These included, for example, the adjustment of tax proceedings, customs proceedings, construction law, criminal administrative proceedings, and others.

Historically, the second law regulating administrative proceedings and which is the current legislation in force in the Czech Republic is Act No. 500/2004 Coll., the Code of Administrative Procedure, which cameinto force on 1 January 2006. This Code will be dealt with in more deatail in the following sections of this chapter.

\section{The current Code of Administrative Procedure - its scope and relation to other regulations (the subsidiarity principle)}

The Act No. 500/2004 Coll. can undoubtedly be considered as a code of administrative procedural law. Although it has a procedural law character, it also contains substantive rules (regulation of public law contracts). However, it is not a complex codification of procedures of public administration, since in addition to the Code of Administrative Procedure, procedural legal standards are also contained in special laws (for more details see below).

As regards to its scope, it is relatively broad, particularly compared to previous legislation. ${ }^{10}$ The scope of the Code is defined both positively and negatively. As regards to the positive definition, it is contained in $\$ 1$ of the Code of Administrative Procedure. Generally speaking, this Act applies to the procedures (1) of the administrative authorities (2) if they exercise competence in the field of public administration (3). In terms of the institutional definition of its scope, the term "administrative authority" should be characterized. In other words: procedures of which bodies are regulated by the Code of Administrative Procedure? Specifically, these are executive bodies (e.g. national and regional administrative authorities,

9 For a detailed interpretation of this act see V. Vopálka, V. Šimůnková, M. Šolín, Správní rád, komentáŕ, Praha 2003, p. 392.

10 P. Průcha, Správní rád s poznámkami a judikaturou, Praha 2019, p. 24. 
occasionally the government and the president ${ }^{11}$ ), authorities of territorial self-governing units (authorities of municipalities and regions), other authorities (e.g. the president of a court, the Supreme Audit Office) and finally legal and physical persons entrusted with the performance of public administration (professional chambers, forest or water guard, etc.).

In addition to the institutional point of view, it is also necessary to reflect on the material aspect, i.e. in what activities and procedures of administrative bodies the Code of Administrative Procedure should be apllied. It must always be procedures within the performance of public administration, namely the authoritative administration. Thus, it is a situation, where the public administration acts authoritatively and from the position of a superior body, which interferes with the rights and obligations of the addressee through the means and instruments of public law (i.e. public power is excercised). ${ }^{12}$ In the words of the Supreme Administrative Court of the Czech Republic, "as an administrative body must be considered the executor of public administration gifted by the sovereign with authoritative powers, not any body fulfilling the public interest in any way". ${ }^{13}$

The current Code of Administrative Procedure (unlike all previous regulations) applies not only to classic administrative proceedings, but also regulates other public administration procedures. These are procedures for concluding public law contracts, issuing measures of a general nature, issuing certificates, statements, opinions and other similar acts. The procedure for handling complaints is also regulated here. It can therefore be said that the Code applies to the vast majority of public administration procedures. The exception is the issuing of legal regulations by the public administration; here the Code of Administrative Procedure does not apply, it would be possible to consider only the basic principles of the activities of administrative bodies ( $\$ 2-8$ of the Code). It is also important to point out that this Act applies both to the performance of state administration and self-government. From the point of view of the individual sections of public administration, there is no restriction, i.e. the Code of Administrative Procedure applies to the administration of construction, school, home affairs, monument care, transport administration, state defense administration, and many others. Only the field of tax proceedings is excluded from its scope, as it is governed by a separate code, namely the Tax Code. ${ }^{14}$

The positive definition of the scope of the Code of Administrative Procedure is supplemented by a negative definition. The Code does not aplly to the legal private

11 L. Jemelka, K. Pondělíčková, D. Bohadlo, Správní rád. Komentářr, Praha 2016, p. 6 et seq.

12 On the definition of public authority cf. judgment of the Constitutional Court of the Czech Republic of 25 November 1993, no. II. ÚS 75/93.

13 Judgment of the Supreme Administrative Court of the Czech Republic of 5 February 2015, no. 6 As 253/2014-40.

14 Act No. 280/2009 Coll., the Tax Code. 
law actions of administrative bodies. This means that, the administrative authority does not act according to this Act, if it acts through private law, and if it does not act and decide authoritatively. It is - for example - a situation where a municipality or state sells its property and concludes a purchase contract.

The Code of Administrative Procedure is a general regulation governing administrative proceedings and at the same time a subsidiary regulation. The principle of subsidiarity means that the Code applies only if a special law does not provide otherwise. On the other hand, however, it is always used unless another law provides for a special procedure or is not precluded by its application. ${ }^{15}$ As the Constitutional Court of the Czech Republic has consistently ruled, any procedural procedure must be based on a legal basis in order to avoid arbitrariness and to guarantee equality. ${ }^{16}$ Special laws are thus in relation to the Code of Administrative Procedure a speciality and are used preferentially. It can be stated that a number of laws governing the performance of public administration contain special regulations relating to administrative proceedings, but almost always are only minor deviations (such as the jurisdiction of administrative authorities, the delimitation of parties to proceedings, the setting of time limits for decisions, delivery methods, etc.). The only exception in this respect is the above-mentioned Tax Code, which constitutes a completely separate and comprehensive legal framework.

\section{The characteristic features of the legal regulation of administrative proceedings, its possible peculiarities}

It should be noted that the present Code of Administrative Procedure is a legal regulation based on the traditions of administrative proceedings in our territory, historical and contemporary case law, as well as knowledge and the conclusions of administrative doctrine. At the same time, its creators were also inspired by foreign legal regulations (e.g. Poland, Austria or Germany). ${ }^{17}$ Last but not least, it reflects the general requirements for the quality of administrative proceedings conducted in any democratic state governed by the principle of the rule of law,

15 Judgment of the Supreme Administrative Court of the Czech Republic of 28 April 2011, no. 1 As 22/2011-64.

16 Judgment of the Constitutional Court of the Czech Republic of 5 November 1996, no. Pl. ÚS 14/96, judgment of the Constitutional Court of the Czech Republic of 4 July, no. III. ÚS 226/1995.

17 Explanatory report to the Code of Administrative Procedure, https://www.psp.cz/sqw/text/ tiskt.sqw?o=4\&ct=201\&ct1=0 (accessed: 1.06 .2004$)$. 
based on a certain standard of European administrative law, in particular resulting from the documents of the Council of Europe and the European Union. Another essential feature brought by the current Code of Administrative Procedure is a certain judicialisation of the administrative procedure, which is, however, a general trend in relation to similar legislation.

We can say that the Czech administrative procedure and its regulation is based on the traditional conception of this procedure as a certain formalized procedure of public administration bodies, whose purpose is to issue a constitutive or declaratory decision regulating the rights and obligations of specific addressees of the public administration in a specific matter. It is therefore an authoritative process of applying substantive administrative law. Administrative proceedings in the Czech Republic are typically built on the principle of written and non-public proceedings (which is a fundamental difference from court proceedings). In addition to protecting the subjective rights of participants, care is also taken to protect and promote public interests. The basic principle is the principle of legality, i.e. administrative proceedings must be implemented with strict respect for substantive, procedural and competence rules. The link between public administration and statutory obligations is one of the primary principles of the state governed by the principle of the rule of law and of the exercise of public administration. ${ }^{18}$

The fact that the whole process of administrative proceedings is comprehensively regulated here, i.e. generally all the stages of the administrative proceedings are regulated here is a significant positive aspect of the legislation. Thus, we find here the legal regulation of the procedure of administrative authorities before the actual initiation of administrative proceedings, when the administrative body collects documents and knowledge important for whether the administrative proceedings should be initiated or not. In addition to the initiation of proceedings and its course before the administrative authority of the first degree, the issuing of the decision itself is regulated in very detailed terms. The regulation of the review of decisions (remedies and supervisory remedies) is also included here, since the administrative procedure is governed by the principle of decision making in two isntances. In the situation that the decision imposes an obligation to perform and this obligation is not voluntarily implemented, execution proceedings may be initiated. The basics of execution proceedings are also regulated in the Code of Administrative Procedure, although in the case of execution for monetary performance, it must subsequently proceed according to the Tax Code.

Compared to the previous legislation, this is a sophisticated, relatively detailed and comprehensive general regulation of the entire course of the administrative proceedings. It should be emphasized that, in addition to the Code of Administrative Procedure, the administrative procedure is also regulated by special laws (the

18 W. Wade, Ch. Forsyth, Administrative Law, Oxford 2009, pp. 17-18; S.J. Schønberg, Legitimate expectations in Administrative Law, Oxford-New York 2000, p. 7. 
Building Act, the Expropriation Act, the Water Act, etc.). These laws, however, only regulate partial deviations or specifics that arise from the specific nature of the proceedings and its subject matter under that particular law. As mentioned above, it can be a different definition of parties, jurisdiction of administrative authorities, deadlines for decision, etc. It is a logical and necessary phenomenon in the regulation of activities and the decision-making of the public administration, because it is very diverse and it is not possible to cover all its specifics by one regulation. On the same point, the Constitutional Court of the Czech Republic states that the Code of Administrative Procedure is a general procedural law that

by its nature may not correspond to all forms of administrative proceedings; in a particular case, therefore, it may seem useful, depending on the nature of the case, to regulate certain types of administrative proceedings in a specific way. ${ }^{19}$

It is therefore a constitutionally conformed situation where the legislature regulates certain proceedings within the Code and some within the framework of special laws. Therefore, when administrative authorities decide in administrative proceedings, they often have to act simultaneously under several laws - according to special laws and, subsidiary, according to the Code of Administrative Procedure.

\section{Judicial control and the review of decisions of public authorities}

The requirement for the judicial control of the decision-making of public administration bodies for the Czech Republic follows both from international law documents and from national legislation. It is closely linked above all to the right to a fair trial, which is guaranteed in particular by Article 6 of the Convention for the Protection of Human Rights and Fundamental Freedoms and also by Article 36 of the Charter of Fundamental Rights and Freedoms, which is part of the constitutional order of the Czech Republic. ${ }^{20}$ In many cases, public administration decision-making falls under the scope of Article 6 of the Convention and it is therefore essential that all attributes of the right to a fair trial be respected. ${ }^{21}$ However, the current regulation of administrative proceedings does not correspond to this in all

19 Judgment of the Constitutional Court of the Czech Republic of 12 July 2001, no. Pl. ÚS 11/2000.

20 This article provides: Anyone who claims to have been shortened in his rights by a decision of a public authority, may apply to a court to review the legality of such a decision, unless otherwise provided by law. However, review of decisions relating to fundamental rights and freedoms under the Charter must not be excluded from the jurisdiction of the court.

21 In more detail D. Hendrych and others, Správní právo. Obecná část, Praha 2016, p. 287 et seq. 
respects (e.g. an independent body does not decide, the procedure is not built on the principle of the public). The fulfillment of all requirements arising from Article 6 of the Convention is thus guaranteed only in the subsequent judicial review of public administration decisions.

The system of judicial control and review of administrative decisions is conceived as dual. It is based on a differentiation of public law and private law and provides for a different regime of protection for public subjective rights versus private subjective rights. ${ }^{22}$ When administrative bodies decide on public subjective rights, ${ }^{23}$ the protection of these rights is ensured within administrative justice in proceedings before administrative courts. On the other hand, where private subjective rights are affected by the decision-making process of the public administration, protection is provided in civil proceedings before civil courts. It should be noted that this concept is not ideal. ${ }^{24}$ Firstly, there is some fragmentation and dualism of legislation and protection, as well as differences in the two types of proceedings and their concepts, and secondly, conflicts of jurisdiction arise over what is covered by public law and by private law.

In the vast majority of cases, administrative bodies interfere with public subjective rights by their decisions. In these cases, judicial protection is provided in proceedings under the Code of Administrative Justice ${ }^{25}$ within the administrative judiciary. The administrative judiciary is conceived as an extension to the system of the means of protection of the rights of persons within the public administration. It is realized only after the proper remedies have been exhausted, i.e. in a situation where the protection of rights in the public administration has not led to redress. This is the so-called principle of the subsidiarity of judicial protection. Another fundamental principle is that the protection of rights in administrative justice can only be claimed. ${ }^{26}$ Thus, the principle of the disposition as an expression of the principle of vigilantibus iura scripta sunt applies exclusively.

In relation to the review of administrative decisions, the means of protection is then an action against the decision of the administrative body. It can be filed only after an appeal against the decision has been exhausted and it is decided by

22 K. Hamuláková, Zamyšlení nad současnou koncepcí soudní kontroly činnosti veřejné správy, "Správní právo" 2012, no. 7, p. 471 et seq.

23 See L. Jemelka, Ý. Podhrázký, M. Vetešník, J. Zavřelová, D. Bohadlo, P. Šuránek, Soudní rád správní. Komentár, Praha 2013, p. 7 et seq., or the judgment of the Supreme Administrative Court of the Czech Republic of 30 September 2004, no. 2 As 22/2004-68.

24 To the question of suitability, respective to the problematic nature of this dualistic concept, as well as to the historical context see J. Mikeš, A. Winterová, F. Zoulík, Problémy nové části páté O. S. R., [in:] Nová úprava správního soudnictví, ed. V. Vopálka, Praha 2003, pp. 199-218.

25 Act No. 150/2002 Coll., Code of Administrative Justice.

26 In more detail L. Potěšil, V. Šimíček and others, Soudní rád správní. Komentář, Praha 2014, p. 43 et seq. 
the regional courts (a specialized senate or a specialized judge). Proceedings before administrative courts are based on the cassation principle. The result of the proceedings is therefore the annulment of the decision of the administrative authority, either for illegality or procedural defects, and the case is returned to the administrative authorities for further proceedings. A specific area is the decisionmaking of administrative authorities on administrative offenses. Only in this area the administrative court can replace administrative reasoning with judicial consideration. This is the so-called moderation right of the court, when the court can waive the imposed administrative penalty or reduce it.

The courts make decisions in so-called full jurisdiction as required by Article 6 of the Convention. If the participant is not satisfied with the decision of the regional court concerning their action, they may continue to defend themselves by filing a cassation complaint with the Supreme Administrative Court. It should be added that some protection in relation to other activities of public authorities is also provided within the administrative judiciary. These include, in particular, an action against the unlawful intervention of an administrative authority and an action against the inaction of an administrative authority.

If an administrative authority, respective its decision, affects private subjective rights, then the protection is provided in civil justice by civil courts in proceedings under the Code of Civil Procedure. ${ }^{27}$ The substance of the proceedings is considerably different from administrative justice proceedings. This procedure is not a cassation procedure. Here, the civil court will again consider the dispute or any other legal matter decided by the administrative authority and decide on it. Its decision then replaces to that extent the decision of the administrative authority.

\section{The influence of the Austrian codification idea on the current form of the legal regulation of the administrative procedure}

Undoubtedly, it is possible to identify the influence of Austrian codification ideas in the conditions of Czech, respective Czechoslovak legal regulations of administrative proceedings. Already in the first codification of administrative proceedings, which was adopted in Czechoslovakia in 1928, reflected these ideas. However, it was a certain specificum that it was only a government order, not an act. On the other hand, it was the first comprehensive codification of administrative proceedings in our territory. It covered the entire administrative procedure,

27 Act No. 99/1963 Coll., the Code of Civil Procedure. 
including the review of the decision and its enforcement. Nevertheless, the legislation was still fragmented, and there were separate legal regulations in relation to a number of administrative proceedings.

On the contrary, the later legal regulations were more of a decodification tendency, they were mainly connected to the communist and socialist regime and were aimed at the unjustified simplification of administrative proceedings (some classical and necessary institutions of administrative proceedings such as deadlines, eligibility of participants, bias, and evidence have been removed from the regulations). The first amendment to the administrative procedure in the form of an act was adopted only in the form of Act No. 71/1967 Coll., which is the forerunner of the current Code of Administrative Procedure. This act has already reverted to the traditional concept of administrative procedure and re-establishes codification ideas in relation to administrative procedure.

Nevertheless, the codification ideas have been reflected most in the current Code of Administrative Procedure. It not only comprehensively codifies the entire administrative procedure, but is completely new and for the first time in our territory there are generally regulated other procedures and activities of public administration, such as issuing measures of a general nature, concluding public law contracts or the realising of less formalized acts such as opinions, statements, certificates, etc. ${ }^{28}$ However, the administrative criminal law, i.e. proceedings on administrative offenses, still has a relatively separate legal regulation. This is the Act on Liability for Administrative Offenses. ${ }^{29}$ Nevertheless, also in relation to it, the provisions of the Code of Administrative Procedure apply. The Code of Administrative Procedure is always conceived as a subsidiary regulation, which regulates everything general and common for administrative proceedings and other procedures and processes of public administration. If it is necessary to regulate matters by way of derogation or beyond the general regulation, the legislator does so by means of special laws. These are then applied preferentially (they are special in relation to the Code). However, they are really only partial adjustments with an attempt to always maintain the general regulation in the Code of Administrative Procedure. The only completely separate regulation is the aforementioned Tax Code.

28 M. Kopecký, Správní právo. Obecná část, Praha 2019, p. 330.

29 Act No. 250/2016 Coll., on liability for administrative offenses and proceedings on them. 


\section{The influence of European law on the activities of the legislature and the courts from the perspective of the legal regulation of administrative proceedings}

Even Czech administrative law, including administrative proceedings, is significantly and in the long-term influenced by the process of the so-called "europeanisation of law". It can be understood and simply described as an acceptance (inspiration) of common and connecting European requirements and their subsequent projection (not only) into the legal order and administrative practice. ${ }^{30}$ It cannot be identified solely with the obligations arising from EU membership, but it is particularly important to emphasize - in the context of administrative proceedings in particular - the importance of the Council of Europe and its acts. ${ }^{31}$ Undoubtedly, administrative law has a dimension which goes well beyond the national law. The principles and rules created by the activities of international and European institutions are respected and used in the national legal systems and in the decisionmaking practice, mutual cooperation between states is developing (not only at national, but also regional or local level). It also asserts the need for an amicable solution to the conflict situations arising from the "coexistence" of different jurisdictions in the European administrative space. All of this has a significant impact on the legislature when drafting legislation on administrative procedural law, and subsequently administrative authorities and courts when applying it in practice.

Even in the creation of the existing Code of Administrative Procedure, the Czech legislature has significantly reflected the requirements and standards represented by the so-called principles of good governance, which were formulated within the European administrative space, mainly thanks to acts adopted by the Council of Europe and complemented by the decision-making practice of the European Court of Human Rights. These are the basic requirements of a legal, generally correct public administration that also respects non-legal aspects and values such as helpfulness, decency, openness and more. These basic requirements and principles were explicitly transposed into the Czech regulation of administrative proceedings. The legislature explicitly enshrined them in $₫ 2$ to $\$ 8$ of the Code of Administrative Procedure in the form of the so-called basic principles of the activities of administrative bodies. These are, for example, the principles of legality, material truth, legitimate expectations, speed and economy, equality, protection of good faith, proportionality or amicable settlement of disputes and cooperation in the interests of

30 L. Potěšil, Europeizace a evropské správní právo, "Časopis pro právní vědu a praxi” 2014, no. 3, p. 222.

31 H. Prášková, Europeizace trestního práva správního, "Právní rozhledy" 2010, no. 13, p. 488 et seq. 
good governance. ${ }^{32}$ These principles work both as direct and enforceable rules of conduct (application function) and serve to correctly and lawfully interpret and apply other provisions (not only) of the Code (interpretative function). In a way, they also "self-bind" the legislator themselves (legislative function). With regard to the fact that the Code of Administrative Procedure regulates not only classical administrative proceedings, but also other procedures and activities of public administration, these principles affect almost the entire performance of public administration in the Czech Republic.

It should also be noted that the Czech legislature respects the development of European administrative law, not only in the context of the regulation of procedural administrative law, but also of general and special administrative law. A significant part of the amendments to Czech legislation is due, among other things, to the implementation of EU law standards or the projection of requirements arising from Council of Europe documents. The so-called soft law is also reflected in this respect, i.e. various recommendations and other non-binding documents of the Council of Europe. ${ }^{33}$ New modern European trends related to public administration decision-making, such as electronization, simplification of procedures, greater participation of addressees and openness of the public administration system, as well as a greater emphasis on the speed and economy of proceedings and minimizing the burden on addressees are also reflected in the Czech regulation of the administrative procedure.

In addition to European law, the case law of the European courts, both the European Court of Human Rights and the Court of Justice of the European Union, is of great importance for the decision-making of the public administration as well as administrative and civil courts. In many cases, the judgments and decisions of the Czech authorities refer to European decision-making practice, the Czech courts and administrative authorities seek to interpret and apply Czech administrative law in a Europe-friendly manner. The case-law of the Constitutional Court of the Czech Republic also significantly helps this. It can be said that it were the requirements and obligations arising from important European documents as well as case law that led to many important reform steps in the Czech legislature, for example in the area of administrative justice, liability of the public administration for damage, but also administrative proceedings and its standards.

32 In more detil to these principles see J. Vedral, Správní rád. Komentář, Praha 2012, p. 67 et seq.

33 D. Hendrych and others, Správní právo. Obecná..., p. 527. 


\section{Leaning towards modernization or maintaining tradition?}

The Czech legislation on administrative proceedings is still based on the traditional concept of this procedural process. It continues to be mostly the written and non-public authoritative decision making of administrative bodies on subjective rights and obligations of addressees of public administration. Here the administrative authority is no longer an impartial arbitrator, but always defends the public interest or interests. It continues to be a process governed by mandatory public law standards, which should ensure the legal and factually correct application of the norms of substantive administrative law.

On the other hand, the legislator reflects the need to respond to new, modern trends in public administration. This is manifested in a number of aspects. On the one hand, the current Code of Administrative Procedure takes into account the fact that public administration is realised also in other forms than the decision-making activities of administrative bodies. Therefore, procedures for issuing measures of a general nature or for the conclusion of public contracts have been newly amended. In general terms, less formalized acts, such as certificates, opinions, statements, etc., are also regulated. This is intended to ensure greater legal certainty for all subjects and also contributes to the principle of legitimate expectations and predictability of decision-making by public authorities; at the same time, it helps to establish a consistent decision-making practice. The legislator also seeks to reflect the requirements of the European standard of good governance. This is undoubtedly reflected in the requirements for the quality of administrative proceedings.

Here, perhaps the most beneficial step was to lay down the so-called basic principles of the activities of administrative bodies within the Code of Administrative Procedure and to set an exceptionally wide scope of these principles. Attention is also paid to greater public involvement in administrative proceedings, especially in the field of environmental protection (e.g. in the form of associations' participation in such proceedings). The public may also be affected by the process of issuing measures of a general nature (e.g. zoning plans) - according to the Code and special laws, it may submit objections and comments. At the same time, emphasis is also placed on the adequate protection of the rights of persons affected by the public administration decisions. Good judicial protection and review of administrative decisions by administrative courts plays a major role here. In particular, their case-law contributes significantly to the legal and factually correct decision-making of public administration. Recently, attention has also been paid to the electronization of public administration and the reduction of the burden on all subjects of proceedings (such as changes in delivery, the support of simplification procedures, etc.). 
It can therefore be assumed that the legislation is based on traditional values and concepts of the administrative processes in public administration. At the same time, however, it seeks to accept and take into account modern trends in public administration, that means for example the simplification of formalized procedures, speeding up and streamlining the performance of public administration, greater awareness and the possibility of addressees to participate in its performance, or even the most effective protection of their rights. Of course, the stimuli of European law and the activities of the European institutions, including case law, are also reflected.

\section{The codification or decodification trend in the area of administrative procedural law?}

It can be said that the current legislation on administrative proceedings was an important step towards the codification of administrative proceedings. More precisely, it was an important step towards the codification of the legal regulation of most procedures and activities in the area of public administration, i.e. not only administrative proceedings. As far as administrative proceedings are concerned, its current legislation is much more sophisticated, detailed and comprehensive.

Of course, public administration represents an extremely diverse activity that cannot be regulated in all respects under one act. Therefore, in addition to the Code of Administrative Procedure, the legal regulation of administrative proceedings is also contained in special laws. However, this regulation in special acts is only partial - there are usually deviations from the general regulation, which regulates some institutions differently from or above the Code. In this respect, there is a clear rule of subsidiarity of this Act and the speciality (i.e. preferential use) of a special law. ${ }^{34}$

Even if new acts are currently being adopted or existing laws are being amended, they do not try to decodificate the administrative procedure. On the contrary, the trend of codification prevails. A major recent example is the recodification of the Czech criminal administrative law, which was realised in mid-2017. One of the essential objectives of this recodification was to eliminate the fragmentation of the previous legislation in this area, to unify the substantive and procedural law (including the administrative criminal proceedings) and simplify the system of administrative offenses. Another significant feature of this reform

34 The principle of subsidiarity is described in details in a monograph of L. Jemelka, Princip subsidiarity správního rádu, Praha 2013, p. 336. 
was the considerable judicialization of administrative criminal proceedings. The legislator has been largely inspired by the Czech Code of Criminal Procedure.

Another positive aspect of the current Code of Administrative Procedure is the fact that it also regulates other procedures and processes in the area of public administration. Also in relation to the regulation of these other forms of public administration activities, there is an interest in codification and clarification and simplification of the legal order, respective administrative law. Part of the Code of Administrative Procedure is the general legal regulation of the procedure for concluding public law contracts, the process of adopting measures of a general nature and also the realization of other administrative acts such as certificates, verifications, statements, opinions and similar (less formalized) activities of public administration. Of course, here too, in some respects, this general regulation is supplemented by a regulation in special laws, for the same reasons as in the administrative procedure. In practice, however, a certain shortcoming appears to be the fact that not all of these regulations in the Code are elaborated in necessary detail. Sometimes, therefore, the necessary partial gaps must be covered by judicial case-law. Overall, the case law of Czech courts (especially administrative courts) significantly "completes" Czech administrative law, including the legal regulation of administrative proceedings and other procedures of public administration.

However, the Code of Administrative Procedure does not regulate all possible public administration procedures. The two most important ones can be mentioned here. This Act does not affect the normative activity of public administration. In other words, it does not apply to the process of adopting secondary legislation by public authorities. With some caution, it is possible to consider maximally the application of the above-mentioned basic principles of administrative authorities' activities to this activity. Unfortunately, however, no other legal act regulates the procedure of public administration normative activity in more detail and somewhat more comprehensively, which seems to be one of the basic shortcomings of the existing legislation. Many aspects are regulated only at the level of internal regulations. It would therefore undoubtedly be appropriate, from a de lege ferenda point of view, to codify this area either by means of a separate act or to incorporate the legislation into the Code.

Furthermore, the Code of Administrative Procedure does not regulate the issue of so-called immediate interventions, i.e. acts often performed on the spot in order to avert direct danger (e.g. police intervention). This is a logical consequence of the nature and content of this form of public administration activity. These are a variety of activities, usually carried out immediately on the spot where a situation needs to be addressed without delay, without any more formalized procedure, decisions being made, etc. However, even in these respects, the legal system lays down the basic conditions and formalities for carrying out such actions, always in the relevant special laws. The question is whether it would be appropriate and functional at all to lay down a general regulation of these interventions, for example 
in the Code of Administrative Procedure. It is a very wide area where only a few generalizing features and conditions for the realization of these acts (the principle of legality, the principle of subsidiarity and the principle of proportionality) can be found. Rather, it can be concluded that codification is not a very appropriate and feasible idea in this area.

\section{The Code of Administrative Procedure and administrative practice}

The legislation in general should primarily serve to clearly establish certain rules of the functioning of society; there should always be a close link between the legislation and the needs of practice. This means, inter alia, that the legislation should be clear, unambiguous, predictable for the addressees and the procedures for implementing the legislation should be as simple, efficient, rapid and as light on the addressees as possible. Also, for all public authorities the applicable law should be certain, comprehensible in terms of application and interpretation, providing sufficient and adequate means and tools to regulate social relations falling within their competence.

In this context, the introduction of simplification procedures in the area of public administration is an important effort in this sphere. If we look directly into the legislation in the Code of Administrative Procedure, public contracts can undoubtedly be regarded as such an instrument. It is a modern tool for the realization of public administration, which enables, on the one hand, greater efficiency of cooperation in the interest of the proper performance of public administration (in particular, coordinating public contracts). On the other hand, this instrument also serves to simplify and replace the often lengthy administrative procedures, where the conclusion of a sub-ordinating public contract between the administrative authority and the addressee can fulfill a similar objective as the administrative decision. For example, a zoning proceeding terminated by a zoning permit or a building proceeding terminated by a building permit may be replaced by a public sub-ordination contract. Moreover, the basic principles of the activities of administrative bodies regulated by the Code include the principle of minimizing the burden on addressees of the public administration, the principle of cooperation between administrative bodies and the emphasis on the consistency of all procedures relating to the rights and obligations of the same person. Of course, the principle of speed and economy is also emphasized.

Other simplifying procedures can be found in special laws regulating individual areas of public administration. A typical law that contains them is the Building Act. 
It expressly provides in $\$ 4$ that spatial planning authorities and building authorities prefer to use simplification procedures and proceed in such a way as to minimize the burden on the persons concerned. For this purpose, the Building Act allows not only in certain situations to enter into a public contract, but also to issue a so-called other act (less formalized), which is a territorial consent or consent to a notified construction. A further simplification is the possibility of combining several procedures in one common (e.g. territorial and construction), or issuing one so-called coordinated opinion ${ }^{35}$ instead of several opinions of the authorities concerned, etc. It can therefore be stated that the legislator is trying to introduce simplifying procedures in the area of administrative law and administrative proceedings, but it must be emphasized that this must not affect respect for the principle of legality, material truth and protection of public interests as well as the rights of the parties to the administrative procedure.

In recent years, the possibility of alternative dispute resolution in the area of public administration has also become increasingly important in the area of administrative proceedings. ${ }^{36}$ In this context, it is necessary to consider in particular the suitability of public law for the application of these means, their selection and setting cases suitable for their use, etc. Unlike private law there is undoubtedly limited scope for their application and it is necessary to respect more limits for their use. However, this does not mean that the use of these means would not be benefitial for public administration and administrative proceedings. In this respect, the Code of Administrative Procedure explicitly lays down, as one of the basic principles, the principle of the amicable settlement of disputes, stating that, if the nature of the present case permits, the administrative authority will attempt to amicably resolve disputes that hinder a proper hearing and resolution $(\S 5) .{ }^{37} \mathrm{In}$ all administrative proceedings, the administrative authority should therefore attempt primarily to eliminate any discrepancies between the parties but also between other entities in the administrative proceedings amicably. In the area of a contentious proceedings, the Code assumes that the proceedings may also be terminated by concluding a settlement instead of issuing a classic decision (\$141).

The possibility of applying mediation in the area of administrative law is therefore increasingly being discussed. Moreover, the Recommendation of the Committee of Ministers RE Rec (2001) 9 on the use of alternative dispute resolution in public administration, which includes mediation as one of the alternatives useful

35 More details in Methodological recommendation of the Department of Spatial Planning of the Ministry for Regional Development: Coordinated binding opinion, http://www.uur.cz/images/ konzultacnistredisko/CastoKladeneOtazky/KoordinovaneZavazneStanovisko_20070216.pdf (accessed: 1.06.2020).

36 In more detail see the monography of P. Molitoris, Konsenzuálne prostriedky alternatívneho riešenia sporov v správnom konaní, Košice 2016, p. 160.

37 In more deatil to this principle see P. Průcha, Správní rád s poznámkami a judikaturou, Praha 2019, pp. 44-45. 
for resolving conflicts between administrations and private individuals, can also be mentioned. Thus, even though mediation is currently carried out more in the area of private law and criminal law, it is increasingly being considered from the perspective of administrative law, which can be viewed positively.

\section{Successes and failures in terms of the codification of (not only) administrative proceedings}

Compared to previous regulations of the administrative proceedings in our territory, it can be clearly stated that the adoption of the current Code of Administrative Procedure was a success (not only) in terms of codification. With regard to history, it is necessary to highlight only the fact that it is a regulation in the form of an act, not a sub-legal regulation. The positive thing is undoubtedly also that the administrative procedure is regulated here in a comprehensive way, from its initiation to the issuance of the decision, its review and possible enforcement proceedings. It is a general regulation intended to serve as widely as possible in all areas of public administration. Therefore, of course, it cannot cover everything. Therefore, administrative proceedings, respective its partial aspects and deviations from the general regulation are also enshrined in special laws. This is a common phenomenon, also typical of other European countries. From the perspective of the Czech Code of Administrative Procedure, it can be considered that the legislator has managed to establish a balanced relationship between the Code and these special laws. The point is that the special laws really contain only specifics, necessary differences, and otherwise this Act shall be followed. The relation between the subsidiarity of the Code and the speciality of special laws is clearly set.

Another success from the point of view of codification efforts is that other procedures and activities of public administration have been codified in the Code of Administrative Procedure. These have already been mentioned several times the conclusion of public contracts, issuing measures of a general nature or performing less formalized acts such as statements, certificates, opinions, and more. Here, too, the proportionality of the Code to special laws was appropriately set. These special laws regulate only the necessary derogations or clarifications and additions in relation to these processes. Even from the point of view of clarity and simplification of legislation, it is favorable for the addressees of public administration that all these public administration procedures are generally regulated in one act (i.e. in the Code of Administrative Procedure). 
In view of the complexity of the codification of procedural activities of the public administration, it may be considered in the future to lay down a general regulation on the adoption of sub-legal regulations by public authorities. This is an area with fragmented legislation, with a large part of the rules being issued only in the form of internal legal regulations, not acts. The normative activity is one of the most important forms of public administration activities and it would therefore be desirable to regulate, for example, within the Code of Administrative Procedure, respective separate act, the basic procedure and rules of the normative process. However, it is a problem for a wider discussion, the question is whether it would be appropriate to include this regulation in the Code, because after all it is a specific process, different from administrative proceedings, on the other hand, it is also the performance of the public administration, respective public power.

\section{Partial conclusions and perspectives of the further development of the legal regulation of administrative proceedings}

Summing up all of the above, it can be concluded that the current legislation on administrative proceedings in the Czech Republic is of a good standard; historically it is the most comprehensive and sophisticated regulation of administrative proceedings, respective of procedural processes. The Code of Administrative Procedure represents both a comprehensive regulation of administrative proceedings and codifies the regulation of other procedures and activities of public administration. The relationship between the Code and special laws (which provide for deviations and specifics) is balanced and logical. At the same time, the legislation is not rigid, but responds to new trends, European requirements and standards, but also to practical needs. This reflection takes the form of partial amendments to the Code of Administrative Procedure, but overall, the concepts and basic principles of the legal regulation of administrative proceedings and other procedures do not fundamentally change. It is therefore a stabilized, functional and relatively effective system, which, although it shows partial deficiencies, these are nevertheless appropriately eliminated especially by the decision-making practice of courts or subsequently by the legislator (e.g. the change of the legal regulation of the nullity of administrative decisions in the Code).

It is therefore not necessary to look for a reform of the current legislation on administrative proceedings in the future. Rather, it could be a continuation of the trend towards simplification procedures, institutions facilitating the speed and economy of proceedings, allowing for higher levels of participation of all subjects 
and higher levels and quality of protection of their rights. At the same time, the amendments should be aimed at removing partial deficiencies and clarifying the legislation (e.g. the issue of handling complaints). From the point of view of legal regulation of other public administration procedures, it would be desirable to de lege ferenda to generally regulate the process of the creation of secondary legislation by the public administration.

\section{Republika Czeska}

Po powstaniu w 1918 r. Czechosłowacji na ziemiach czeskich obowiązywało przez pewien czas dawne prawo austriackie, zaś na Słowacji - węgierskie. Postępowanie administracyjne na terytorium Czech jako części tego państwa zostało po raz pierwszy skodyfikowane $\mathrm{w}$ formie rozporządzenia rządowego $\mathrm{nr}$ 8/1928 o postępowaniu w sprawach należących do władz politycznych. Było ono wzorowane na orzecznictwie sądowym i regułach praktyki administracyjnej z czasów Monarchii Habsburskiej oraz nowo utworzonego Najwyższego Sądu Administracyjnego. Nie wszystkie kategorie postępowań zostały jednak objęte tym unormowaniem. Dwie kolejne kodyfikacje postępowania administracyjnego także miały postać rozporządzeń rządowych nr 20/1955 i nr 91/1960. Oba zdeterminowane były epoką, w której powstały, odzwierciedlając założenia ideologii socjalistycznej.

Przyjęty w ostatnim z wymienionych aktów sposób unormowania postępowania administracyjnego stawał się z biegiem lat coraz mniej adekwatny do potrzeb i z tego powodu uchwalono w Czechosłowacji ustawę nr 71/1967 o postępowaniu administracyjnym (Kodeks postępowania administracyjnego). Po rozpadzie Czechosłowacji, w Czechach zdecydowano się na zastąpienie wzkazanej ustawy nową, tj. obowiązującą od 1 stycznia 2006 r. ustawą nr 500/2004 - Kodeks postępowania administracyjnego. Akt ten nie stanowi jednak pełnej regulacji postępowań prowadzonych przez administrację publiczną, ponieważ równolegle obowiązują przepisy odrębne. W odróżnieniu od unormowań wcześniejszych, kodeks stosowany jest nie tylko w sprawach będących przedmiotem ogólnego postępowania administracyjnego jurysdykcyjnego. Reguluje on także inne kwestie procesowe, takie jak zawieranie umów administracyjnych, wydawanie aktów generalnych, wydawanie zaświadczeń, oświadczeń, opinii i podobnych dokumentów oraz postępowanie skargowe. Przepisy zawarte w kodeksie stosowane są zarówno przed organami administracji rządowej, jak i jednostek samorządu terytorialnego. Z tych powodów uznaje się go za akt obejmujący większość postępowań przed organami administracji, bez względu na przedmiot sprawy. Wyłączenie obejmuje jedynie postępowanie podatkowe, unormowane przez kodeks podatkowy. 
Wyczerpujące uregulowanie wszystkich faz postępowania administracyjnego w kodeksie uznaje się za jego zaletę. Normuje on precyzyjnie reguły wydawania decyzji administracyjnej, realizujące zasadę dwuinstancyjności, środki odwoławcze oraz inne, nadzwyczajne środki prawne. W akcie tym unormowano także podstawy postępowania egzekucyjnego, natomiast w odniesieniu do przymusowego wykonywania decyzji podatkowych obowiązują odnośne przepisy kodeksu podatkowego. Przepisy odrębne, takie jak prawo wodne, prawo budowlane czy wywłaszczeniowe, wprowadzają pewne odstępstwa od postępowania przewidzianego w kodeksie, wynikające ze specyfiki poszczególnych kategorii spraw.

Autorka zauważyła, że system sądowej kontroli w Czechach jest niejednorodny, a rozróżnienie przebiega według podziału na publiczne prawa podmiotowe i prawa prywatne. Ochrona tych pierwszych poddana jest kompetencji sądów administracyjnych, zaś roszczenia wynikające z prawa prywatnego, nawet jeżeli potrzeba ich ochrony wynika z wydania decyzji administracyjnej, realizowana być może przed sądami powszechnymi. Do mankamentów takiego rozwiązania zalicza się rozwarstwienie i dualizm unormowań oraz siłą rzeczy - ochrony prawnej, a także - powstawanie sporów kompetencyjnych.

W podsumowaniu wskazano, że wprowadzony w Czechach system postępowania administracyjnego spełnia wysokie standardy legislacji. Uznano go za najbardziej rozwinięty i zarazem wszechstronny w historii czeskich regulacji. Ocenia się, że przepisy kodeksu cechują się elastycznością i nowoczesnością, odpowiadają także wymaganiom praktyki i standardom unijnym. Z kolei uregulowania odrębne ustanowiono w sposób logiczny i wyważony. Kodeks poddawany jest pewnym zmianom, ale jego podstawowe założenia pozostają nienaruszone. Tworzy on zatem ustabilizowany, funkcjonalny i stosunkowo skuteczny system, którego niedoskonałości eliminowane są przez orzecznictwo sądowe, a następnie przez ustawodawcę.

W ocenie Autorki nie ma potrzeby reformowania tak funkcjonującego postępowania administracyjnego, lecz raczej poszukiwania mechanizmów upraszczających instniejące już procedury, instytucji służących przyspieszeniu postępowania i obniżania jego kosztów, jak również zapewniania wyższych standardów partycypacji w postępowaniu dla stron i innych podmiotów oraz poziomu realizacji przysługujących im praw. Zmiany legislacyjne mogłyby polegać też na usunięciu pewnych niedoskonałości i uczynieniu niektórych przepisów bardziej czytelnymi, np. w zakresie rozpoznawania skarg. Pożądane byłoby też uregulowanie reguł tworzenia prawa przez administrację.

(tłum. Joanna Wegner)

Kateřina Frumarová, Doc. JUDr., Ph.D. Head of the Department of Administrative Law and Financial Law, Faculty of Law of Palacky University in Olomouc. For 20 years, she has been teaching and researching at the Faculty of Law, specializing in the administrative law and administrative justice. Author (or co-author) 
of several monographs and professional books and textbooks in the area of administrative law, as well as the author of more than 100 scientific articles and contributions at scientific conferences. She works as an evaluator of the National Accreditation Office of the Czech Republic and as an external evaluator for the Council for Research, Development and Innovation (advisory body to the Government of the Czech Republic). 


\section{Chapter VI \\ Hungary}

András Patyi, Ph.D., Prof. Dr. habil. judge of the Curia drpatyiandras@yahoo.com

ORCID: 0000-0003-0273-0544

iD https://orcid.org/0000-0003-0273-0544

\section{The stages of the evolution of the Act on Administrative Procedure}

\subsection{Beginnings (up until 1901)}

Thinking on public law in Hungary was strongly determined by the emphasis placed on independence by the Hungarian state (to varying degrees throughout history), even at the expense of revolutions and wars of independence. From the 10th century until 1949, Hungary had a historical constitution, similar to that of England, the constitution was not contained in a single fundamental statute, but was composed of several important "basic" or "fundamental" laws and other significant legal documents. The parts of the Hungarian historical constitution consisted of numerous important basic laws, the Admonitions of Saint Stephen, the customary law detailed in the Tripartitum of István Werbőczy, and the Inaugural Diplomas of the kings or queens. The Doctrine of the Holy Crown - concerning the Holy Crown of Hungary and connected with the person of Saint Stephen (968-1038), the first Hungarian king (as Stephen I) from the Árpád dynasty, and traditionally known as the founder of the Christian state of Hungary - should also be emphasized. The doctrine specifically connected the state's legal personality to this crown. The Holy Crown is the emblem of the Hungarian state and the Hungarian people. ${ }^{1}$ The most important developer of the notion of the Holy Crown was the Hungarian noble István Werbőczy (1458-1541), an ideologue and compiler

1 Á. Timon, A királyi hatalom és a Szent Korona elmélete, [in:] Á. Timon, Magyar alkotmány- és jogtörténet, Budapest 1903, pp. 479-526; F. Eckhart, A Szent Korona-eszme története, Budapest 1941, p. 356. 
of noble law (customs, Latin: consuetudo, ius consuetudinarium). ${ }^{2}$ The 1848-1849 revolution was followed by the Austrian-Hungarian Compromise of 1867 (Ausgleich) which, in the decision to use the name Austro-Hungary Monarchy with its hereditary territory and other states under Habsburg rule, was intended to reflect the key status of Hungarians in public law. However, the Hungarian role in actual (political) decision-making was considerably less than would be evident from this political structure. ${ }^{3}$

No two public administrations are identical. Both practical and theoretical issues can present themselves in different ways to different types of states. The recognition and the conception of problems can differ by state. This does not mean that states do not seek similar or even common models. ${ }^{4}$ Administrative procedures and related laws - at least in part - depend on codes of administrative procedures (or lack thereof) and administrative court procedures (both contentious and non-contentious). Hungarian legal literature was already dealing with the issue of procedural law prior to $1945 .{ }^{5}$ At the same time, Hungarian administrative procedural law exists in an international environment and, despite the country's linguistic isolation, it was published as part of international handbooks both before $1945^{6}$ and during the socialist period (1945-1989), ${ }^{7}$ and is still being published today. ${ }^{8}$ However, the fact remains that financial administrative court procedures (as early as from 1883) are the first rules among Hungarian administrative procedures. Certain administrative procedural rules already existed prior to the establishment of the Royal Administrative Court (1896). During the socialist period (1949-1989) it was heavily stressed, erroneously, that Hungarian administrative law has not got a subject prior to 1867, as Hungary was not independent. ${ }^{9}$ Nevertheless, today's Hungarian administrative

2 István Werböczy was the collector of the customary law of nobility, such as his contemporaries, the Polish Jan Łaski (1456-1531), or the Czech Kornel Viktorín Vsehrd (1460-1520).

3 Gy. Szabad, Hungarian Political Trends between the Revolution and the Compromise 18491867, Budapest 1977, p. 184.

4 A. Tamás, $A$ közigazgatási jog elmélete, Budapest 2010, p. 76-77.

5 Not long ago, a number of these volumes were reprinted. See: the series of Államtudományi Klasszikusok, vol. I-VII, eds. A. Patyi, L. Trócsányi, Budapest 1998-2018.

6 G. Ferdinandy, Verwaltungsverfahren, Verwaltungsgerichrsbarkeit, [in:] G. Ferdinandy, Staats- und Verwaltungsrecht des Königreichs Ungarn und seiner Nebenländer, Hannover 1909, pp. 191-199; D. Márkus, Ungarisches Verwaltungsrecht, München 1912, pp. XI, 579.

7 L. Szamel, I. Ivancsics, Administrativnyj process, [in:] Vengerskoe administrativnoe pravo, ed. S. Berényi, Moskva 1990, pp. 384-481.

8 L. Lörincz, Administrative Law, [in:] Introduction to Hungarian Law, ed. A. Harmathy, the Hague, London, Boston 1998, pp. 39-50; A. Boros, Act on Administrative Proceedings, [in:] Hungarian Public Administration and Administrative Law, eds. A. Patyi, A. Rixer, Gy. Koi [co-ed.], Passau 2014, pp. 419-445. For clashing opinion, see: A. Jakab, Wissenschaft vom Verwaltungsrecht: Ungarn, [in:] Handbuch Jus Europaeum IV. Verwaltungsrecht in Europa: Wissenschaft, eds. A. Bogdandy, S. Cassese, P.M. Huber, Heidelberg 2011, pp. 365-395.

9 L. Szamel, A magyar közigazgatás-tudomány, Budapest 1977, p. 412. Concerning the science, was partly more permissive: A. Csizmadia, A magyar közigazgatás fejlődése a XVIII. századtól a tanácsrendszer létrejöttéig, Budapest 1976, p. 560. 
theory has transcended these opinions, and Hungarian administrative science has been studied since the Polizeiwissenschaft of the 18th century. ${ }^{10}$

The development of Hungarian administrative procedural law took place at later date than that of criminal procedural law and civil procedural law, and its aims and tendencies were also different. ${ }^{11}$ The preparatory steps preceding measures for substantive administrative decisions, and the decision itself (the administration of the case), constituted a key subject during the late feudal age, i.e. much earlier than the Compromise. During the Habsburg period, several resolutions (royal announcements) issued at a very high level attempted to simplify those activities of court and national offices which related to preparing decisions and administration, and at the same time tried to make them quicker and more effective. In 1724, an "administrative directive" appeared which dealt fundamentally with issues that today are regarded as of a procedural or case-management nature, and yet are relevant from the point of view of handling cases: registration, issuing of documents, preparation of the minutes of deliberations, presenter reports, inter-office communications and the precise recording thereof, and the introduction of forms. Several announcements followed the first during the 18th century $(1754,1769$, and 1784). Finally, in 1792, court decrees laying down detailed rules for administration completed the royal announcements. Subordinate national offices and other, centrally-administered public offices had to act according to regulations issued for central (court) bodies. The era in which Hungarian administrative science adhered to Polizeiwissenschaft (1769-1840) was the period of the administrative legal point of view. The first Hungarian scholar of this science was the judge of servitors (Hungarian: szolgabíró, Latin: iudex nobilium, German: Stuhlrichter, Slovak: Slúžni) and legal writer (publicist) Ignác Zsoldos (1803-1885), who was one of the first jurist (legal scholar) members of the Hungarian Academy of Sciences. The role of judges of servitors and their offices was strengthened by the fact that the distant central administration managed from Vienna was only imperfectly built up. Under the Bach - System and Schmerling Provisorium that followed the 1848-1849 revolution, the teaching of administrative law began and an independent professorship of administrative law was set up at the University of Pest.

The separation of public administration and justice occurred in 1869. In addition to independent administration of criminal justice, the so-called administrative criminal law materialized from 1879 (Act XL of 1879 on Violations) in the procedures of administrative bodies. In 1869, judicial powers were withdrawn from the counties and Royal Free Cities to the Royal Courts of Appeal. Thereafter, the

10 Gy. Koi, Évszázadok mezsgyéjén. Négy magyar közigazgatás-tudós útkeresése és életpéldája. Zsoldos Ignác (1803-1885) Récsi Emil (1822-1864) Concha Győző (1846-1933) Magyary Zoltán (1888-1945), Budapest 2013, p. 178.

11 I. Stipta, A közigazgatási bíráskodás elözményei Magyarországon, [in:] 150 év. A magyar polgári átalakulás alkotmányos forradalma. Jogtörténészek 1848-ról, ed. I. Vörös, Budapest 1999, pp. 139-154. 
administrative bodies only passed judgement on the most minor offences (falling within administrative criminal jurisdiction). On the basis of the first law on boroughs (local councils) in 1870, the boroughs performed their own local governmental activities, took part in the provision of public administration, and facilitated state administration. The regulation of external and internal procedures was not strictly separated in the law, as it primarily regulated the procedures of boroughs. It nevertheless laid down the forum system and the right of appeal to the minister against adverse decisions.

The notion of judicial review of administrative decisions (or administrative justice) in Hungary was not unprecedented. Győző Concha (1846-1933) first addressed this topic at an academic level. ${ }^{12}$ Act XLVIII of 1883 set up the Court of Financial Administration. The court dealt with financial, tax and duty cases, including enforcement complaints. The Council of Ministers decided in cases of jurisdiction and competence. Act XXVI of 1896 on the Hungarian Royal Administrative Court (hereinafter referred to as the RAC) set up the Administrative Court based mainly on Austrian precedents, several important differences were enacted however. The law came into force on 1 January 1897, and the Financial Administrative Court was incorporated into the Administrative Court. The RAC (as a supreme court for administrative cases) decided only as a special jurisdiction (only in cases enlisted in the Act), and was a single-level judicial body that acted as a special court (i.e. it was the only administrative court in the country). It could also decide on the validity and legality of certain governmental decrees, but not as a constitutional court though. Its decision was not an example of norm control (ex post review), as all courts in the country had the power to interpret the law and decide, whether a certain decree is applicable or not. The RAC's president and judges had an equal status to those of the Curia (the Supreme Court).

The financial division of the RAC considered tax and duty cases, and the general administrative division other cases. The latter included cases on: parish, borough, and state pensions; public health; religious and public education; water rights; public roads and railways; animal health; forestry, hunting, and fishing; community housing (until 1920); and domestic servants, day labourers, and labourers. ${ }^{13}$

12 Gy. Concha, A közigazgatási bíráskodás az alkotmányosság, és az egyéni joghoz való viszonyában, Budapest 1877, p. 123.

13 J. Martonyi, A közigazgatási bíráskodás és legújabb kori fejlödése, Budapest 1932, p. 80. A. Patyi, Közigazgatási bíráskodásunk modelljei, Budapest, 2002 p. 254; idem, Közigazgatás - Alkotmány - Bíráskodás, Győr 2011, p. 271; idem, A magyar közigazgatási bíráskodás elmélete és története, Institutiones Administrationis VIII, Budapest 2019, p. 335. 


\subsection{The Simplification of Administration Act and the first drafts for administrative procedures (1901-1957)}

The first law explicitly dealing with the regulation of external administrative procedures was the Act XX of 1901 on the Simplification of Public Administration. This Act was a very mixed piece of legislation in terms of its regulatory subjects. It regulated the administrative-criminaljurisdiction (concerning violations or, with a present-day expression: infractions) of the police, and the handling of the monetary proceeds of offences, as well as public and "orphan" money, but more importantly it regulated the system of delivery and legal remedies of judgments. The effect of this legislation was to establish the uniform system of legal remedies aligned with administrative judicial processes. This Act only regulated legal remedies and the system of delivery of documents. The main goal of framing the law in relation to legal remedies was to eliminate the remedies "irregularities" through simplification in the nomenclature of classes and individual legal remedies. In accordance with the new rule restricting appeals, they could no longer be lodged against authorities of third instance, just as they could no longer be lodged against decisions of second instance with equal content as those of first instance. This law introduced (comprehensively regulated) the complaint for rehearing of disputed cases.

Let us review the opinions of contemporary jurists following the advent of the law. Ferenc Vasváry (1872-1952) first dealt with administrative procedures from the explicit point of view of administrative law in his 1902 text book on administrative law: Administrative Regulation, Legal Remedies, Delivery, and Administrative Implementation. ${ }^{14}$ The term "administrative regulations" (or administrative rules) for the general rules of administrative procedure was first used in Hungary by F. Vasváry, presumably following the model of the German Verwaltungs(gerichts) ordnung. Ferenc Vasváry made clear that the principles of procedures (including contentious and non-contentious administrative court procedures) gained customary regulation at least in broad outline. ${ }^{15}$

Andor Sigmond, a teacher and director of the Academy of Law in Nagyvárad (Oradea), wrote the first substantial Hungarian monograph on administrative procedural law. ${ }^{16}$ The book describes the administrative authority and the parties as the actors of the administrative procedure. It distinguishes procedures between the authority and the parties, those between authorities, and the internal procedures of authorities. His work also examines evidential and review procedures in detail. ${ }^{17}$

14 F. Vasváry, Közigazgatási eljárás, [in:] F. Vasváry, A magyar közigazgatás központi alapszervei. Bevezetéssel a magyar közigazgatási jogtudományba, Budapest 1902, p. 111-144. On scientific career of this legal scholar, see: Gy. Koi, Évszázadok mezsgyéjén..., pp. 272-273.

15 F. Vasváry, Közigazgatási..., pp. 135-140.

16 A. Sigmond, A közigazgatási eljárás vezérfonala tekintettel a törvényhatósági közigazgatásra, Budapest 1904, p. 535.

17 Ibidem, pp. 123-500. 
Regarding the period after 1901, it is worth mentioning the expansion of inspection of the legality of state supervision over the local councils' jurisdiction by the Administrative Court, and the establishment of the Jurisdictional Court in 1907. Concerning the regulation of the administrative procedures, it is important to note the Act XXX of 1929 on the Simplification of Public Administration. Section II (Legal Remedies, Official Classifications and Procedural Regulations) of this Act contained some twenty paragraphs of explicit procedural provisions. One of the main goals of the Act was to accelerate public administration procedures, and thus it sought to restrict appeals to reasonable limits and, during the setting of jurisdiction, to concentrate the majority of cases within individual authorities. Some assessments have emphasized the drawbacks and restricted nature of this legislation. In addition to defining the right of appeal in general terms and as a "parties' right", it generalized appeals against first instance decisions, but it tied appeals against (final) decisions of second instance to the explicit provisions of later legislation. It reregulated petitions for review, petitions for exception, rehearing requests, and the location and deadline for the presentation of appeals, and it also provided for the suspensive effect of appeals, that is for appeals to have a suspensive effect on enforcement, while petitions for review, appeals to the highest authority, and rehearing requests do not have this as a general rule. This Act was the harbinger of thinking on comprehensive procedural regulation, particularly when supplemented by Act XVI of 1933 (which, unfortunately, did not enter into force), which sought to introduce further simplification of the forum system and a complete single level of appeal, abolishing the legal remedy character of the ministerial and central authorities. Certain provisions of the 1929 Act remained in force until the 1950s, and its final remaining provisions were repealed by $\$(2)$ of Section 90 of Act IV of 1957.

The approach in which the necessity for or, at some rate, the possibility of general rules of administrative procedure is denied was practically dominant up until the appearance of the scientific school led by Zoltán Magyary (18881945)..$^{18}$ Probably as an effect of the Austrian public administration procedure law created in 1925, and the academic debates connected with its creation, in the second half of the 1920s a clear viewpoint emerged on the unified and general regulation of (external) administrative procedures by Ede Márffy (18851947), who (while assuming the need for special regulations), regarded the codification of procedural regulation as both possible and necessary. ${ }^{19}$ Zoltán Magyary himself confessed that the legality and, to no small extent, the efficiency of public administration depends on the extent of unified and general regulations of procedures. The legality of public administration is not only guaranteed

18 L. Szamel, A magyar..., pp. 161-190; on Magyary school, see: A. Csizmadia, Bürokrácia és közigazgatási reformok Magyarhonban, Budapest 1979, pp. 434-451.

19 E. Márffy, Magyar pénzügyi és közigazgatási jog l., Budapest 1926, p. 446. 
through the administrative justice, but also through the manner of regulations of public administration, and so an exceptionally important role is ascribed to the codification of public administration procedural law. ${ }^{20}$ While the laws up until then regulated almost exclusively the legal remedies, general procedural regulation had to rest on a complete and comprehensive scientific foundation. This groundwork was carried out in $1937^{21}$ by József Valló (1913-1976) within the framework of the Magyary school. In addition to laying the theoretical foundation, he prepared a draft of a potential procedural law. This draft was never passed into law, and the 1939 work of Jenő Szitás suffered the same fate. ${ }^{22}$ In his draft taking into account the rules of criminal and civil procedural law, the Austrian code, and the generalized rules of particular procedural law provisions, J. Valló created a body of general procedural law whose rules were in part primary, and in part provided for derogation (i.e. subsidiary or ancillary). According to his draft, their scope would not extend to the areas of local administration of justice, criminal proceedings of police authorities, financial administrative proceedings, disciplinary proceedings and proceedings connected with electoral law. József Valló prepared a second draft ${ }^{23}$ in 1942, in which he took into account the Szitás draft. The draft of Jenő Szitás (1886-1958) and assistant lecturer and Magyary's follower József Vallós first draft (1937) were unified in J. Vallós second draft (1942). Magyary points out that J. Szitás' proposal deliberately neglected to say whether the regulation should take place in the form of an Act of Parliament or a decree, and the Section 149 proposal was, instead, a work of procedural technique, which counted to a lesser degree (than touched upon by criticism of it) on the characteristics of public administration procedure.

József Vallós last, united draft from 1942 on General Administrative Regulations contains the following main parts: 1) general provisions: the scope of the law; authorities; the parties and its legal representatives; deadlines; maintaining order

20 Z. Magyary, A magyar közigazgatás racionalizálása, Budapest 1930, pp. 149-150. The polyglottal professor took a lecture at Warsaw IIAS World Conference (1936), and published in French as keynote speaker (general rapporteur), the English and Hungarian monographic version was published in Polish, too: idem, The Industrial State, New York City 1938, pp. 202; idem, Organizacja władz a zwłaszcza rola szefa rzadu w administracji publicznej, Warszawa 1937, p. 150. Magyary after the Warsaw Conference, was elected the vice president of IIAS, the only world organisation of public administration studies. His thoughts on administrative procedure law, see the relevant chapter of his main work: idem, $A$ közigazgatási eljárás, [in:] Z. Magyary, Magyar közigazgatás. A közigazgatás szerepe a 20. század államában, a magyar közigazgatás szervezete és jogi rendje, Budapest 1942, pp. 592-624.

21 J. Valló, Közigazgatási eljárás. A közigazgatás eljárás célja, természete, alapelvei és eddigi tételesjogi szabályozása; a közigazgatási eljárás törvényi szabályozásának előkészitése, Budapest 1937, p. 205.

22 J. Szitás, Közigazgatási eljárás, [Administrative Proceedings], Budapest 1939, IV, p. 47.

23 J. Valló, Törvénytervezet az Általános Közigazgatási Rendtartásról indokolással, Budapest 1942, p. 94. 
at the courtroom; delivery; 2) procedure in the first instance: starting of the procedure: summons and petition; report and record; preparation of decision-making process; exposition and evidence in general; evidences; 3 ) resolutions, and binding force; 4) legal remedies; 5) procedural charges; 6) administrative enforcement; 7) mixed and enacting provisions.

\subsection{The first codification of public (state) administration procedures: the Procedural Law 1957-1981}

Act IV of 1957 on General Rules of State Administrative Procedures (hereinafter referred to as Et., in Hungarian: eljárási törvény - Procedural Law), which came into force on 1st October 1957 (a short year after the 1956 revolution), was the first code to contain general procedural rules for state administration. ${ }^{24}$ It is self-evident that, before this, there was no codified law concerning procedural regulations. At the same time, it would not be true to state that the law did not regulate the procedures at all. The National Assembly gradually drew the individual areas and issues relating to official procedures into the scope of legislation (The previous drafts were not ignored during the codification). ${ }^{25}$

According to Ferenc Toldi (1914-1991) the Et. was a "modern work of independent origin" in contrast to Western and socialist codes from provisions of which the special procedural rules could differ, and so they were essentially secondary as sources of law, while the Hungarian Procedural Law permitted some exceptions, aside from which it must function as a primary source of procedural law. ${ }^{26}$

It is also worth to mention, that the suppression of administrative justice (judicial review of administrative decisions) started shortly after the end of the Second World War, and then in 1949 the Administrative Court and the Jurisdictional Court were both abolished. ${ }^{27}$ It should be noted that after 1949, the names of several branches of law were replaced with other names (that had previously existed, but were less commonly used) by legal experts "impregnated" with the Marxist ideology of the socialist era. As so "public administrative law" (Öffentliches Verwaltungsrecht) was changed to "state administration law" (Staatsverwaltungsrecht). In the period between

24 A. Patyi, „A kódexek kora.” Az eljárási törvények változásai az 1957. évi IV. törvénytől (Et.) az általános közigazgatási rendtartásig, [in:] A. Patyi, A.Zs. Varga, A közigazgatási eljárásjog alapjai és alapelvei, Budapest 2019, pp. 117-160.

25 A. Patyi, A magyar közigazgatási bíráskodás elmélete és története, [The Doctrines and History of Administrative judiciary], Institutiones Administrationis, VIII. Dialóg Campus, Budapest 2019, pp. 335.

26 F. Toldi, L. Szamel et al., Az államigazgatási eljárási törvény magyarázata, and Közgazdasági és Jogi Könyvkiadó, ed. Gy. Fonyó, Budapest 1976, p. 759.

27 Act I and II of 1949. 
1949 and 1957, prior to the introduction of the Et., there was the possibility to appeal before an ordinary court in the small number of cases of "acting against state administration", ${ }^{28}$ and this was the case for admission to the electoral register; disputes related to employment; and complaints against seizure of movable property. The contemporary jurisprudence recommended expansion to other types of cases according to the Soviet model, which subsequently took place, but the number of types of cases remained small. In 1972, the procedural rules on judicial review of decisions by state administration were mostly "transferred" to Chapter XX of the Civil Procedure Code (abbreviated in Hungarian as: Pp.) - polgári perrendtartás), basically along the Soviet model. ${ }^{29}$ The main form of remedy was the administrative appeal (as ordinary remedy), while a couple of extraordinary remedies also existed within the administration itself.

\subsection{The "old new" second code: the Modification and Consolidation Act (1981-2004)}

Utilizing close to a quarter of a century of experience in administrative cases, and carrying out the necessary modifications, the National Assembly modified the Procedural Law with a specific legislative technique (the so-called "incorporal" method). ${ }^{30}$ The rules of the law remaining still in force after the modification were consolidated into a uniform structure with modifications and additions, it created a new single text (thus not as an amending law) and promulgated in 1981 as Act I of $1981 .^{31}$ While the legislature itself established the consolidated text of rules remaining from the Et., i.e. it passed into law the consolidated text under the title Modification and Consolidated Text of Act IV of 1957, it did in fact formally create a new law. From then on, neither the modified rules nor those remaining in force from the Et. could be referred to as Act IV of 1957, but - identically for the modifying and additional rules - only as Act I of 1981. The official abbreviation for this law was Áe. in Hungarian (in Hungarian államigazgatási eljárási törvény - State Administrative

28 The so-called classifying theory of acts although German-origin, but was adsorbed into Hungarian law via Soviet mediation.

29 D. Kiss, A közigazgatási perek, [in:] J. Németh, D. Kiss, A Polgári Perrendtartás magyarázata, Budapest 1999, pp. 1355-1471.

30 The essence of incorporal method (contrary to the „patchwork-type” legislation) is, that the new law (legal regulation) contains (incorporates) the sustained parts of the previous law (legal regulation), the modified ones and the new provisions as well. See: K. Mártonffy, A szabatos törvény, Budapest 1932, pp. 15-16.

31 Act I of 1981 on Modification and Consolidation of Act IV of 1957 on General Rules of State Administrative Proceedings. 
Proceedings Act). The appeal procedures remained the main ordinary remedy, and the access to court in administrative cases (the possibility of judicial review) was slightly narrowed.

The modification (amendment) of the Constitution of the People's Republic through Act XXXI of 1989 created the constitutional basis for the judicial review of public administration. The Ministerial Council (MC) Decree (today: Government Decree) determined the scope of decisions that could be reviewed became unconstitutional. In December 1990 Constitutional Court annulled $^{32}$ the texts of Section 72 of the Áe. and the MC Decree by 31st March 1991. Act XXVI of 1991 decided on the temporary opening of the path to a general administrative justice. At the same time, the Chapter XX of the Pp. was named "Administrative Proceedings", ${ }^{33}$ and numerous sectoral laws established procedural rules. From that time, the local courts located at the seats of the county courts were the first instance judicial forums to start a judicial review procedure. From 1999, first instance administrative jurisdiction was elevated to the county level.

\subsection{The third code: the "Ket." Act (2004-2016)}

Act CXL of 2004 on General Rules of Administrative Proceedings and Services (hereinafter referred to as: Ket., in Hungarian i.e. közigazgatási eljárási törvény - Act of Public Administrative Proceedings) became the third code of administrative procedural law. After greater and lesser changes carried out in the appeal system and modification of details rules, the legislative will was ripe for change. In 1999, the government provided for the drafting of a new code of administrative procedures, and this was carried out in 2004. The Ket. became a significantly longer and more complex law than its predecessor, reflecting the expectations of sectoral portfolio interests, and thus it also contained certain rules which cannot be considered general procedural regulations. The original Act soon proved to have deficiencies, and so Act LXXXIII of 2005 (often called the "omnibus act" or lex satura) came into effect together with Ket., also on 1 November 2005, and in Chapter XII it tried to correct the deficiencies of the provisions of Ket. Parallel to this, the Expert Committee of Administrative Proceedings was established, which made an effort to support law application activity with "methodological resolutions".

32 For the role of the Constitutional Court see: A. Patyi, Protecting the Constitution: the Characteristics of Constitutional and Judicial Review in Hungary, 1990-2010, Passau 2011, p. 63.

33 M. Kengyel, Közigazgatási perek, [in:] M. Kengyel, Magyar polgári eljárásjog, Budapest 2003, pp. 423-436. 
Meanwhile, administrative court procedures remained in the Chapter XX of the Pp., though in 2005, a separate law was created on administrative non-contentious procedures. ${ }^{34}$ Based on international comparisons, it could have been known at that time that contentious administrative court proceedings ${ }^{35}$ cannot indefinitely be part of civil procedure. ${ }^{36}$

\subsection{The fourth code: the Ákr. Act and the separate Administrative Court Procedures Act (2018)}

Act CL of 2016 on General Administrative Regulations (hereinafter referred to as: Ákr., in Hungarian i.e. Általános közigazgatási rendtartás) stands for effective regulation. The new code maintains the predecessors approach and it deals with proceedings in which the administrative authorities act in cases of legal entities (parties) outside of the administration. These proceedings take place in such a way that concrete rights and obligations are established for the parties. The proceedings presuppose that the administrative body acts as an authority and assumes the active cooperation of the other subjects of the proceedings. Procedural law relationships are created during the administrative procedure. Sections 114-115 of the Ákr. contain some rules on judicial review of the administrative decisions, highlighting that administrative court procedures are remedial proceedings subject to application - as it was the case in the prior codes as well.

The creation of a separate administrative court procedural Act became one of the main goals of the State Reform Committee (2014-2018). On the proposal of the committee Government Resolution 1011/2015 (I. 22) established the Administrative Procedural Codification Committee to prepare the draft for the new code. In 2017, the path led to the enactment of the separate Code of Administrative Court Procedure, the Act I of 2017 (Hungarian abbreviation: Kp. - közigazgatási perrendtartás). This Code independently regulates administrative court cases, highlighting the Code of Civil Procedure. Act CXXVII of 2019 modified the Kp. inserting the rules on non-contentious administrative procedures as Chapter XXVI of the Kp.

Independently organized administrative courts with general jurisdiction, and the establishment of a separate Administrative High Court (vis-à-vis operating as

34 Act XVII of 2005 on the Modification of Act III of 1952 on the Code of Civil Procedure, and on the Rules to be Applied in Certain Non-contentious Administrative Proceedings.

35 D. Kiss, A közigazgatási perek célja, jelentősége, alapvető jogforrásai és tárgya, [in:] D. Kiss, Z. Rónay, Á. Sántha, P. Szabó, A különleges perek. Kérdések és válaszok a Polgári perrendtartás a Különös Részéböl, Budapest 2006, pp. 99-136.

36 For detailed explanation of the remedy system: A. Boros, A. Patyi, Administrative Appeals and Other Forms of ADR in Hungary, [in:] Alternative Dispute Resolution in European Administrative Law, eds. D.C. Dragos, B. Neamtu, New York, London, Heidelberg 2014, pp. 279-336. 
part of the ordinary court system), emerged on the grounds of historical tradition between 1897 and 1949. ${ }^{37}$ This was symbolized by a new law. On December 12, 2018 the Hungarian Parliament enacted Act CXXX of 2018 on Administrative Courts and Act CXXXI of 2018 on certain transitional rules before this Act enters into force. Based on the recommendations of the Venice Committee, the Hunga-rian Parliament adopted the XXIV of 2019 on Additional Guarantees of the Independence of Administrative Courts, which was passed by the National Assembly on 1 April 2019. However, based on the government's decision of 31 October, the Minister of Justice stated that this will not occur, and the government will ensure a clear framework for administrative justice through other means

\section{The scope of the binding force of the Code of Administrative Procedure, and the issue of the subsidiary application of the provisions on general administrative procedure}

Before 1945, one of the most studied topics of administrative procedural law was the issue of binding force (res iudicata in administrarive law). Today one of the main objectives of procedural rules is to assist (ensure) the adoption of final rulings or even cause them to be adopted (executed) if needed. Thus, binding force is a legal construct of key importance. Of the impacts of res iudicata, the binding force of substantive law, i.e. invariability, is of greater importance. What can be changed is not final, not unappealable, if something has been altered, it was not (cannot have been) final (binding) in terms of substantive law. Authority procedures and administrative litigation, which is based on it, and which affects and even "sets" the formal binding force of authority resolutions must be regulated together, with respect to each other and concurrently. Administrative procedure and administrative court procedures form a unity in terms of logics, substantive law and procedural techniques. Legislation acknowledged and embraced this fundamental truth as late as the joint, reciprocal formulation and entry into force of the Ákr. and the Kp. Furthermore, the rules of tax administration procedure have been laid down in alignment with these two acts. While resolutions can be altered (or annulled) within the system of public administration as well, such altered resolutions are never, in theory, final (binding), and never, on their own, generate

37 A. Patyi, Útközben. Alapkérdések a szervezetileg önálló közigazgatási bíráskodás megszervezése kapcsán, „Acta Humana” 2019, vol. 29, no. 1, pp. 77-106; P. Hajnal, Nézz magadba és emlékezz! (Személyes gondolatok), ibidem, pp. 41-54. 
(unconditional) binding force in terms of substantive law. Courts decide on the legality or otherwise of a decision adopted by an administrative body. While so doing they may also establish whether substantive and procedural law has been broken or whether the law applied was erroneously interpreted. During the codification the relationship between the Kp. and the Âkr. was determined by the goal that the shortest possible time should lapse between the commencement of a proceeding and the court's final ruling, and this is still the case.

\section{Characteristic legal constructs and peculiarities of the Act on Administrative Procedure}

Numerous legal constructs could be mentioned in connection with both past and current legal regulations. The Et. can be grasped through its foundation, straightforward regulations and novelty as a new model. One of the unique novelties of the Áe. was that administrative authorities were not allowed to request citizens for data that had already been available in their own database.

Though not a novelty proper, what is called "decision with suspensive effect" [in Hungarian: függö hatályú döntés] (section 43 of the Ákr.) is another new legal construct irrespective of the fact that it has been known since 1 January 2016 (still having the Ket. as the code in force). A decision with suspensive effect is taken within 8 days from the commencement of a proceeding. In the decision with suspensive effect, the authority may decide whether a) the authority shall pay the applicant an amount equal to the duty payable for the procedure or an administrative service fee or, in the absence of such, 10,000 Hungarian forints; b) the applicant shall be exempt from payment of the procedural costs; $c$ ) the applicant is entitled to exercise the right he applied for. The decision with suspensive effect shall contain the date specified as a calendar day with effect from which date the decision will have legal effects. The authority does not decide on the application on the merits in the decision with suspensive effect. If the authority fails to adopt a decision on the subject matter of the application, the applicant is entitled to exercise the right applied for.

Another unique legal construct of the Ákr. is "self-revision on the basis of the statement of claim", which stipulates the amendment or revocation of the authority decision on the basis of the statement of claim if the decision has violated the law. Where the authority agrees with the content of the statement of claim and there is no adversary in the case, the authority may also revoke a decision which is not in violation of the law or it may amend the decision according to the content of the statement of claim. 


\section{The relationship between the legal construct of administrative procedure and the model of judicial review}

When addressing the issue of adjudication, and tackling both legal issues and facts, the RAC exercised meritorious and reformatory powers (capable of adjudicating a case finally and upon its merits, deciding not only questions of law but also questions of fact). Only exceptionally did it exercise cassatory powers, i.e. it had been included in the cassatory model only partially, as the powers of the administrative court also included the power to change a challenged measure. (The Austrian law only provided cassatory powers.) As discussed in historical background, later, after 1949, judicial reviews diminished in importance.

Administrative court procedure (administrative litigation) is not and never was the continuation of administrative proceedings, therefore, it is not part thereof, either. Civil procedural code (the old Pp.) and, based on them, the science of civil procedures considered administrative court proceedings as a type of civil litigation, and part of civil justice, which, to all appearances, had legal justification: administrative litigation was regulated in the civil procedure. Administrative litigation (already under the old scheme) was at least as administrative as it was litigious. Concerning the merits of the courts' activity, judicial review could be seen as public administration under special litigious (adversarial) circumstances rather than the meting out of justice proper. This view is likely to hold true mainly for the cases where courts may change (alter) authority decisions, i.e. replace them with theirs. With the enactment of a separate code of procedures, administrative litigation has been removed from the scope of civil justice and become a separate type of litigation. We argue that courts also carry out special supervision and review, and that the proceedings that they institute are definitely not the continuation of those by public authorities despite the fact that they also contemplate upon or even apply administrative procedural rules and the rules of substantive law. However, as the legal impact of a decision taken in the litigation is mainly to do with an administrative decision (which it either repeals, whereby it does not allow it to enter into force or to be executed, or alters it, or allows it to enter into force or to be executed), the litigation cannot be separated completely from the administrative proceedings concerned.

Therefore, administrative litigation following an administrative authority's proceeding cannot be labelled as a proceeding under administrative law; rather, it should be categorised as a court procedure of administrative kind. ${ }^{38}$

38 A. Patyi, Administrative justice in Hungary, [in:] The Transformation of the Hungarian Legal System 2010-2013, ed. P. Smuk, Budapest 2013, pp. 145-154. 


\section{The influence of Austrian codification ideas on the working out of contemporary legal solutions}

When describing current trends in Hungary, we must establish unambiguously that, contrary to past trends, when laying down the Ákr., legislators considered the 1937 and 1942 draft administrative procedures by József Valló as their model. Though the draft procedures did not enter into force, the $1957 \mathrm{Et}$. also adopted some of its solutions. This is also reflected in the title of the Code in force: Code of General Administrative Regulations. Research on foreign impacts on public administration as an academic discipline in Hungary has revealed that academics of administrative law were au courant with not only German and French, but also English and Italian legislation between 1842 and 1942, and in addition to relying on national tradition (responsiveness to law and state affairs, the Historical Constitution, the doctrine of the Holy Crown, a rather peculiar "vármegye" system /a system of counties/ capable of generating national cohesion versus Austria's weak and remote centralised system of public administration /before 1867/), they also incorporated foreign solutions in their research..$^{39}$ It is true that as regards the various branches of administrative law monographs examining Austrian and other influences on, for instance, the legal constructs of procedural laws are far and few between. However, it is also a fact that the 1925 Austrian AVG, which was seminal on a global scale, influenced not only Polish, Czech, Yugoslavian, Ukrainian and Bulgarian codes, but also Hungarian drafts. This means the influence of the works of the Austrian Friedrich Tezner, Rudolf Herrnritt and Albert Mannlicher as well as those of the Polish-born Austrian Otto Komorzynski-Oszczynski studying administrative procedures is perceptible in J. Vallós 1937 draft, which also has theoretical and monographic sections. Furthermore, in addition to the French works of Jose Gascon y Marin (a Spanish professor at IIAS and a contemporary of Magyary), who studied administrative safeguards, the works of academics researching administrative procedural law, which was getting an increasingly strong focus in Hungary, were also incorporated into J. Vallós works. Other influencers include Nándor Baumgarten, Elek Boér, Sándor Krisztics, Károly Némethy, Gyula Panajoth, Andor Sigmond, Jenő Szitás, Móric Tomcsányi and István Viczián. ${ }^{40}$ József Valló also referred to, in addition to developments in civil procedural law, certain examples of criminal procedural law in Hungary as well. A strong Austrian impact on the rules applicable to access to documents, summons, the refusal of a testimony and supporting documents was present in the 1937 draft. The 1957 Et. was

39 Gy. Koi, Évszázadok mezsgyéjén..., pp. 45-334.

40 J. Valló, Közigazgatási eljárás..., p. 206. 
uniquely Hungarian in the sense that, in addition to the general procedural code, it was another new model. It did not strive to address all the aspects of administrative procedure; instead, it intended to define fundamental uniform standards to be adopted in administrative proceedings, however, in more detail than do regulatory frameworks. ${ }^{41}$ The German-Austrian classification of administrative acts (Verwaltungsakte) was adopted after 1949 through the mediation of Russian textbooks.

In addition to a strong influence exerted by the regulatory efforts of the EU, a shift to the strong constitutional fundamental principles has materialised in the main procedure and both contentious and non-contentious administrative court procedures recently. Attempts at simplicity and rapidity characterise both the states that have adopted the German model and Hungarian regulations. The similarity based on the Austrian distinction between simple and complex procedures is a recent development. Likewise, the Ákr. makes a distinction between summary and full procedures. (The old Hungarian civil procedure also provided for a summary procedure.) The summary procedure comprises automatic decision-making (section 40 of Ákr.), a summary procedure proper (section 41 of Ákr.) and the adjudication of an application in a full procedure (section 42 of Ákr.).

\section{The impact of European law on the activities of national legislature and judicature}

The intention to accede to the European Union, even though there was no express obligation of legal harmonisation imposed, was sufficient justification, well before the 2004 codification, for the approximation of Hungary's laws to their West European counterparts, the latter offering, in some respects, more modern solutions that can better comply with the requirements of the rule of law. When modernising regulations, it is important that international obligations and the expectations of the acquis be taken into consideration. Pursuant to Article 4(1) of the Treaty on the European Union, "[i]n accordance with Article 5, competences not conferred upon the Union in the Treaties remain with the Member States". This also holds true for public administration. The need for uniform administrative procedural rules (as part of EU procedures) facilitating effective operation has also arisen in the European Union recently. Pursuant to the principle of subsidiarity and proportionality, no member state powers can be withdrawn without good reason. Accordingly, neither EU bodies nor the administrative bodies of the member states have provided any applicable regulations or codes. These rules do exist. However,

41 F. Toldi, L. Szamel et al., Az államigazgatási eljárási..., pp. 27-28. 
they have been incorporated into legal standards (norms) at the various levels of legal regulations or even as parts of non-legal regulations. Furthermore, they also contain significant administrative principles. ${ }^{42}$ A similarity between Hungarian administrative procedural law and trends in administrative procedural law in the EU is that both the new Hungarian code of administrative procedural law and the ReNEUAL model code seem to be in favour of self-revision. ${ }^{43}$ Statutory provisions pertaining to the correction (replacement), adjustment or revoked of legal acts should also be noted here. A statutory provision of that ilk of the Ákr. (section 115) is the amendment or revocation of a decision on the basis of the statement of claim. Regarding the application of the acquis by the courts of the countries that acceded to the EU in 2004, Curia, the highest instance judicial forum of Hungary has studied the preliminary ruling procedure between 2004 and 2012. The member states filed 216 cases. Of them, 96 were of administrative nature (with agricultural aid, customs, consumer protection and public procurement as their subject matter). Most of the 216 cases ( 64 or $30 \%$ ) were submitted by Hungary (10 by the Curia, 4 by courts of appeal, 40 by regional courts and 10 by local courts). Many cases put forth by Hungarian judges, e.g. C-324/11. (Tóth case) and C-273/11. (Mecsek Gabona case) (both VAT-related cases). ${ }^{44}$

\section{Openness to innovation - does tradition or modernisation as an aim prevail in the actions of the legislature?}

The purposes of codification currently reflect both adherence to traditions and modernisation efforts. Temporary halts aside, Hungarian administrative procedural law made every effort to keep up with global trends (N.B. the 1925 Austrian code was only preceded by the 1889 Spanish procedural regulatory framework). The 1937, 1939 and 1942 drafts did not enter into force and remained "private drafts". By contrast, the Czech, Polish, or Yugoslavian efforts were more successful in the 1920s and 1930s than the Hungarian. Although the 1957 Et. served as a new model, conflicting interests inside the government did not favour the full application of these regulations (one of the advantages of the code was its simple

42 A hazai közigazgatási hatósági eljárási jog karakterisztikája, eds. A. Patyi, A. Boros, Budapest 2018, pp. 50-53.

43 ReNEUAL Model Rules on EU Administrative Procedure, eds. P. Craig, H.C.H. Hofmann, J.-P. Schneider, J. Ziller, Oxford 2017.

44 P. Hajnal, Nézz magadba és emlékezz! (Személyes gondolatok), "Acta Humana” 2019, vol. 29, no. 1, pp. 49-50. 
straightforward regulations). Frequent modifications including those running counter with the underlying concept harmed the overcomplicated "Professorenrecht" regulation offered by the Ket. considerably. The original text had to be modified as early as the period between the date of its promulgation and that of its entry into force (vacatio legis). The 2016 Ákr. is not an old-standing law. Here reference can be made to the numerous new legal constructs mentioned above.

\section{Codification of administrative procedures and decodification trends}

Both the reform and the simplification of public administration were a "buzzword" in Hungary as early as the 1870's and 1880's. As has been mentioned in the historical background, a law on the simplification of public administration was enacted in 1929 and 1933. Increasingly conspicuous from 2015 the government's unambiguous efforts aimed at simplifying administrative procedures sought to decrease administrative burden, streamline administration, increase competitiveness and provide a better guarantee of the exercise of the constitutional right laid down in Article XXIV (1) of the Fundamental Law, which states that "[e]veryone shall have the right to have his or her affairs handled impartially, fairly and within a reasonable time by the authorities". As approximately 120 laws and 135 government decrees contained rules that deviated from certain provisions of the Ket., and by 2015 only a limited number of the provisions of the Ket. had remained in force in its original form. Precursors to the simplification of administration were the Simplification Programme of the Magyary Project, which was implemented in the 20102014 government term, adopted in government resolution no 1304/2011 (IX. 2.) and aimed at reducing the administrative burden of citizens and the Simple State Project set forth in government resolution no 1405/2011. (XI. 25.), which aimed at reducing the administrative burden of businesses. The 2014-2020 Strategy of the Development of Public Administration and Public Services was adopted (with the participation of the State Reform Committee) as the central document of the development of public administration. The updating of authority procedures was interconnected with the tasks related to the establishment of a "simple state" set out in the strategy which necessitated deregulation, an ongoing review of statutory regulations and the termination of existing duplications. 


\section{Codification of administrative procedures and practice}

The codification of administrative procedures (1957) and that of the procedural rules of administrative courts (1883 and 1896) affected the development of the theoretical and practical aspects of the procedural rules of administrative law. 20 years after the Et. the relevant legal literature emphasised that the proportion of challenged resolutions was $10 \%$ in the case of both 1 st and 2 nd instance resolutions. This had dropped to $5 \%$ in the case of 1 st instance resolutions by the late 1970s. Two thirds of the actions were unjustified, and only one third justified. ${ }^{45}$

The resolutions of the Constitutional Court after the 1989-1990 regime change and constitutional law exerted the same impact on the development of case law. Compilations of decisions help the public obtain information on the relevant law. The pro domo section of the journal entitled A Compilation of Administrative and Economic Decisions is an interesting tool providing assistance for administrative courts.

\section{Successes and failures - what has not been achieved?}

All the contributions described in the historical section based on which there is Hungarian administrative procedure and administrative law could be called success. The greatest advantage of the Ákr. is also its greatest disadvantage. It has "slimmed down" most of the text of the Ket. and got rid of the rules assumed to be unnecessary and of non-general nature. Policy makers of the main branches of administration did not want to waste tried and tested rules, and would incorporate, often verbatim, the "thrown-out" provisions into their own separate, special statutory regulations "on the sly". However, the provisions thus removed from the Ákr. have left a major gap mostly for civil or public servants applying the Ákr., because the rules of the individual administrative legal institutions (constructs) assumed to bear general relevance have not been consolidated in one general code; rather, they are contained in various statutory regulations or in court decisions based on rules similar to or identical with the rules of the Ket. This way of thinking must be adopted by not only authorities, but also citizens, courts, prosecution services and even academics because they have not been used anything like this.

45 F. Toldi, L. Szamel et al., Az államigazgatási eljárási..., pp. 27-28. 


\section{General conclusions and comments on the development prospects of the Act on Administrative Procedure}

Overall, the Ákr. has been intended to meet the expectations of the Fundamental Law (Basic Law of Hungary, ie. the Hungarian Constitution) and international legal instruments. It endeavoured to formulate the rules applied in all authority proceedings concisely. Feedback from those applying the law reveals that except that they are now shorter, these concise rules have not received a broad welcome from those in public administration jobs. The Et., the Áe. and the Ket. were all excellent laws of their own kind. We should not underestimate the preparatory work that goes into the formulation of codes like them. That said, codes of procedural laws cannot be evaluated on their own. Special procedural and other administrative rules must also be taken into consideration. The goal of the Ákr. to formulate new procedures capable of handling both simple and complex proceedings and the related procedures adopted as a new type of authority cooperation is a progressive ambition. The paradigm shift in legal remedies (judicial reviews) and the new regulation needed for the primacy of administrative litigation sparked off more heated debates. The legal remedy regime is one of the characteristics of the given administrative procedural code.

\section{Węgry}

Autor przypomniał, że na Węgrzech w 1869 r. dokonano rozdziału administracji od władzy sądowniczej, a w 1883 r. utworzono Administracyjny Sąd Finansowy do rozpoznawania spraw finansowych, podatkowych, celnych i z zakresu egzekucji. Został on, ustawą nr XXVI z 1896 r., przygotowaną na podstawie orzecznictwa austriackiego, włączony w struktury utworzonego wówczas Sądu Administracyjnego. W odróżnieniu od systemu austriackiego, kompetencje tego Sądu zakreślono szeroko i obejmowały one także możliwość ustalania faktów i podejmowania orzeczeń o charakterze reformatoryjnym w sprawach enumeratywnie wymienionych w ustawie.

Na Węgrzech - jak wskazał Autor - postępowanie administracyjne zostało uregulowane po raz pierwszy w ustawie $\mathrm{nr}$ XX z $1901 \mathrm{r}$. o uproszczeniu administracji, odnoszącej się do systemu doręczeń i środków prawnych od wydawanych orzeczeń. W 1907 r. ustanowiono Sąd Kompetencyjny i poszerzono kognicję Sądu Administracyjnego o kontrolę rozporządzeń rządowych i ministerialnych, naruszających prawa władz samorządowych. Z kolei ustawa nr XXX z 1929 r. o uproszczeniu administracji publicznej była zwiastunem myślenia o kompleksowych 
ogólnych przepisach proceduralnych. Jednakże potrzeba wprowadzenia przepisów ogólnych o postępowaniu administracyjnym, aż do czasów szkoły prawa Zoltána Magyaryego (1888-1945), była na Węgrzech negowana. Przeprowadzone w 1937 r. przez Józsefa Valló prace koncepcyjne nad ustawą o ogólnym postępowaniu administracyjnym stanowiły m.in. rezultat obowiązywania austriackiej ustawy procesowej z 1925 r. Oprócz opracowania podstaw teoretycznych przygotował on projekt ustawy procesowej, który jednak nigdy nie wszedł w życie. Dzieło Jenő Szitása z 1939 r. spotkało ten sam los, choć materiał ten został uwzględniony w kolejnym projekcie autorstwa Józsefa Valló z 1942 r.

Po drugiej wojnie światowej rozpoczął się proces eliminowania sądowej kontroli administracji na Węgrzech. W 1949 r. Sąd Administracyjny i Sąd Kompetencyjny zostały zniesione. Pierwszy kodeks postępowania administracyjnego uchwalono ustawą nr IV z 1957 r. w sprawie ogólnych zasad państwowego postępowania administracyjnego. Akt ten wszedł w życie 1 października $1957 \mathrm{r}$. Został on poddany gruntownej modyfikacji w $1981 \mathrm{r}$. Zasadniczym środkiem prawnym było wówczas odwołanie administracyjne, przy czym funkcjonowały również pewne nadzwyczajne środki (postępowanie nadzorcze i kontrolne). Sądowa kontrola była dopuszczalna wyłącznie w niewielkiej liczbie spraw, wymienionych w rozporządzeniu Rady Ministrów. Zmiana Konstytucji Republiki Ludowej ustawą nr XXXI z 1989 r. stworzyła podstawy konstytucyjne do kontroli sądowej administracji publicznej, a w wyniku orzeczenia Trybunału Konstytucyjnego utraciły moc przepisy ustawowe i rządowe ograniczające kontrolę sądową decyzji administracyjnych. Następną kodyfikację postępowania administracyjnego przeprowadzono ustawą nr CXL z 2004 r. o ogólnych zasadach postępowania administracyjnego i usługach, która była aktem znacznie bardziej obszernym i złożonym niż jego poprzednik, ale niektóre spośród zawartych w tej ustawie uregulowań nie nosiły procesowego charakteru.

Ostatnia kodyfikacja dotycząca postępowania administracyjnego dokonana została ustawą nr CL z 2016 r. w sprawie ogólnych przepisów administracyjnych. Następnie uchwalono ustawę $\mathrm{nr}$ I z 2017 r. Kodeks postępowania przed sądami administracyjnymi, która weszła w życie 1 stycznia 2018 r. Reguluje ona kompetencje sądów do kontrolowania działalności administracji oraz główne zasady postępowania przed sądami administracyjnymi z odesłaniami do kodeksu postępowania cywilnego.

W 2019 r. parlament węgierski przyjął pakiet ustaw wprowadzających niezależne sądownictwo administracyjne. Jednakże, jak przekonuje Autor, w wyniku podnoszonych na Węgrzech i za granicą przeciwko tym rozwiązaniom głosów krytycznych, w maju i w końcu 2019 r. rząd węgierski zasugerował przesunięcie wprowadzenia nowego systemu niezależnego sądownictwa administracyjnego. Ostatecznie, w wyniku wprowadzenia ósmej poprawki do węgierskiej ustawy zasadniczej, która weszła w życie 13 grudnia 2019 r., gwarancje funkcjonowania niezależnego sądownictwa administracyjnego usunięto $\mathrm{z}$ węgierskiego porządku konstytucyjnego. 
András Patyi, Professor of Public Administrative Law, Ph.D., dr. habil., dr. h.c. Judge of the Curia (Supreme Court), president of the Panel of Local Government Cases; Head of Department of Public Law and Police Law at National University of Public Service, Faculty of Law Enforcement. Former Rector of the University (20122018). Previous chairman of the State Reform Committee (2014-2018) and the National Election Commission (2013-2018). 


\title{
Chapter VII
}

\section{Italian Concept of Law on Administrative Proceedings. Opera aperta?}

\author{
Maciej Wojtuń, Ph.D., Assistant professor \\ Department of Administrative Procedure \\ University of tódź, Faculty of Law and Administration \\ mwojtun@wpia.uni.lodz.pl \\ iD https://orcid.org/0000-0003-1049-6022
}

\begin{abstract}
Un'opera d'arte, forma compiuta e chiusa nella sua perfezione di organismo perfettamente calibrato, è altresì aperta, possibilità di essere interpretata in mille modi diversi senza che la sua irriproducibile singolarità ne risulti alterata. Ogni fruizione è così una interpretazione e una esecuzione, poiché in ogni fruizione l'opera rivive in una prospettiva originale
\end{abstract}

\section{Foreign influences on the Italian administrative law}

As Michael Martinek emphasises,

Comparative Jurisprudence deals with various national legal orders in order to describe and to explain their common features, their differences and their peculiarities, in order to analyse and to comprehend their approximations to each other and their distances from each other, and in order to ascertain and to understand their similarities, their strangenesses and their mutual influences. This description reveals that comparative law is decidedly more than mere knowledge of foreign law. The pure determination and cognizance of positive norms, articles or sections of one or more foreign legal systems with respect to a specific legal issue must not be confused with comparative law; that is just knowledge of foreign law. ${ }^{1}$

1 M. Martinek, Comparative Jurisprudence - What Good Does It Do?, Warszawa 2016, p. 43. 
What makes this scientific domain fascinating, is its inherently anti-dogmatic and dynamic nature. Entering the field of comparative studies, it is no longer possible to treat the law as a structure of unchanging concepts - on the contrary, we are almost forced to perceive it as a living phenomenon, rooted in culture and history, intrinsically active and in constant development.

Therefore, a comparative research of administrative proceedings offers not only an understanding of foreign solutions of legal problems in the field of administrative procedure, but also a unique possibility for a deeper insight into the structures of power. Observing how particular legal rules and principles determine the administrative action in a given political context provides a better understanding of the relationships between the State and its citizens. Administrative procedure can be viewed as a mirror reflecting, through a specific manifestation, the general idea of exercising power.

For this reason, the very idea of codifying the administrative procedure in the times of 20th century Europe should be seen from a wider perspective, embracing specific political structures and a particular philosophy of law, derived from the Enlightenment. The development of modern administration since the end of the 19th century was of utmost importance in this respect, increasing the need for legal institutions improving the mechanisms of exercising power. Another factor that had an impact on the shape of administrative procedure, was the concept of the Rule of Law. It is evident that one of the main goals of codification of administrative procedure, which took place in different countries in the 20th century, was to limit the scope of administrative discretion.

One should not forget that despite the obvious influence of modernist tendencies, Austrian codification reflects the imperial political culture and tradition of the Habsburg administration. The idea of the adoption of a code did not appear in Austria until the mid-1920s but it did not come out ex nihilo - it evolved, like a phoenix, rising from the ashes of the Habsburg Empire. Its basic institutions had been developed in the Austrian legal doctrine and case law from the time of Franz Joseph. The main reasons were the problems associated with the bureaucracy of those times. Paradoxically, the legal institutions developed for the needs of imperial administration were taken over by the republican nation states created as a result of the fall of the Habsburg Empire. Respecting this legal tradition by most of the Habsburg succession's countries can be connected with the relatively mild Austrian policy towards the peripheral areas.

The legal institutions of the Habsburg Empire grew deeply into the political and social fabric of Galicia, Czechia, and Hungary and constituted a natural basis for the reconstruction of legal systems in independent nation states after the First World War. Italy clearly differs from other countries, the territories of which were ruled by Vienna in the 19th and 20th centuries. While strong tensions continued in the Italian territories occupied by Austria from the end of the 18th century, a cautious policy was exercised in the rest of the Empire. The Austrian tradition 
never settled down in northern Italy. Therefore, while an Austrian citizen from Galicia would call Franz Joseph his emperor, it would not be possible to look for similar testimonies in Piedmont or Lombardy. There is a significant description of this anti-Austrian pose in the literature, dating back to the 18th century.

As Stendhal wrote in The Chartreuse of Parma:

In the middle ages, the Milanese had been as brave as the French of the Revolution, and their courage earned the complete destruction of their city by the German emperor. But their chief occupation, since they had become his "faithful subjects" was to print sonnets on pink silk handkerchiefs whenever any rich or well-born young lady was given in marriage. Between such effeminate habits and the deep emotions stirred by the unexpected arrival of the French army, a great gulf lay. Before long a new and passionate order of things had supervened. On May 15, 1796, a whole people became aware that all it had hitherto respected was supremely ridiculous, and occasionally hateful, to boot. The departure of the last Austrian regiment marked the downfall of the old ideas. [...] The continuance of the watchful despotism of Charles V and Philip II had plunged the Lombards into impenetrable darkness. They overthrew these rulers' statues, and forthwith found themselves bathed in light. ${ }^{2}$

The above-cited phrases shed some light on the problem of the Habsburg presence in northern Italy. It makes us also aware of the reasons why Italy chose a French-oriented way of regulating administrative procedure (French administrative paradigm), ${ }^{3}$ while many European countries followed the Austrian codification patterns in this respect. Basic cultural influences and legal concepts infiltrated Italy during the Enlightenment and in the 19th century not through the Brenner Pass (Passo del Brennero), but via the Great St Bernard Pass (Colle del Gran San Bernard), an ancient road running from France to Rome. In the opinion of Giuseppe Franco Ferrari, at the end of the 18th century the army of French emperor Napoleon Bonaparte entered Italy, leading to the conquest period which changed both the geopolitical situation of the territory, as well as cultural and legal instruments, favouring the diffusion of civil and administrative French law, along with the human rights models created during the French Revolution. ${ }^{4}$ In consequence, it was France, not Austria, that played a major role in shaping Italian administrative law. As it was raised by Bernardo Giorgio Mattarella,

Napoleon and his armies had brought into Italy many trends, such as the simplification and rationalization of administrative organisation and devices like those of administrative litigation. And if, on a constitutional level, the Restoration meant a return to the past, on an administrative level those tendencies and those devices remained, insofar as they were functional to the characters which the monarchies of the 1800 s assumed. ${ }^{5}$

2 Stendhal, The Chartreuse of Parma, New York 1901, http://www.gutenberg.org/files/57638/57638h/57638-h.htm (accessed: 11.03.2020).

3 See P. Aimo, Historia de la Organisación Administrativa Italiana, [in:] Derecho Administrativo Italiano, ed. G.F. Ferrari, México 2013, p. 1.

4 G.P. Ferrari, Introduction to Italian Public Law, Milano 2008, p. 21.

5 B. Mattarella, Administrative Law in Italy: An Historical Sketch, "Revista de Direito Administrativo", jan./abr. 2016, vol. 271, p. 16-17. 
The above-mentioned author points out, however, that the influence of French models on Italian administrative and legal culture, although significant, was not absolute, since a number of classical institutions which distinguish the French administration were not adopted in Italy, such as "«administrative uniformity» and the powerful administrative «élite», the «Conseil d'État», the prefects". 6

\section{The origins of the Law no. $241 / 1990$}

In the 20th century, Italian public administration was acting in an intrinsically, discretionary way, resulting in little space for transparency and participation in administrative procedure. What is more, in Italy, similarly to France, administrative action was focused on the concept of the administrative act, thus not much importance was attached to the procedure.

As Francesco Lemetre and Raffaella Miranda argue, the administration was recognised a wide discretion (unampia discrezionalita) in conducting the procedure and no guarantee of participation was recognised to the interested parties, affected by the administrative activity. ${ }^{7}$ Other authors underline the multi-level problems concerning the Italian post-war administration. Its structure was shaped in constant tension between centralization and opposite tendencies. What is more, specific areas of administrative law were governed by their own procedures. ${ }^{8}$

The administration, leading its own life, obscure and hidden from public opinion, was one of the main forces in the political landscape. In addition to official administration, there was a phenomenon in Italy known as "sub-government" (sottogoverno), ${ }^{9}$ that could be described as a parallel administration. This peculiar system of agencies and institutions, governed by political parties and their clients, performed various social and economic needs, by-passing its "legal" counterpart. ${ }^{10}$ It was stated that,

In particular, faithful party supporters are appointed to these top posts and they use the large patronage network (sottogoverno) to allocate material benefits to voters strictly on a partisan basis. This is done to create a patronclient network which provides the parties with a source of votes and funds at election time. ${ }^{11}$

6 Ibidem, p. 17.

7 F. Lemetre, R. Miranda, Diritto amministrativo, Napoli 2015, p. 231.

8 P. Alberti, El procedimiento administrativo, [in:] Derecho..., p. 315.

9 G. Pridham, Political Parties and Coalitional Behaviour in Italy, New York 2013.

10 M. Clark, Współczesne Włochy. 1871-2006, Warszawa 2009, p. 517.

11 G. Cristiano, The Waning of the Two Giants: The Electoral Decline of the Italian Christian Democratic Party and the Italian Communist Party, Ontario 1993, p. 25. 
Since Italy was struggling with more urgent internal problems in the first thirty years after the Second World War, it was difficult to think about the codification or even piecemeal unification of administrative proceedings. It was only in 1990 that partial unification of administrative proceedings was achieved in this country. Before Law no. 241/1990 entered into force, the legal situation of an individual towards the administration had been marked by a considerable degree of uncertainty. One can even speak of a peculiar "black legend" of the Italian administration, which consisted of the opacity of procedures, excessive length of the proceedings, formalism and casuistry, as well as widespread corruption phenomena. The constant tension between the strongly felt regionalism and centralist ambitions of the state apparatus should also be added. The Italian public administration was perceived not as an institutional structure based on the principles of law, acting in the interest of the citizens, but primarily as a sovereign power in the system of particracy (partitocrazia), which, in practice, was often abused by those who exercised it. It is no wonder that the doctrine and court case law commonly pointed to the threat of administrative authorities violating the border separating the discretion from arbitrariness.

The constitutional basis for the functioning of the Italian administration is enshrined in Article 97 of the Italian Constitution. ${ }^{12}$ It states, that

Public offices are organised according to the provisions of law (secondo disposizioni di legge), so as to ensure the efficiency (buon andamento) and impartiality (l'imparzialità) of administration. The regulations of the offices lay down the areas of competence, the duties and the responsibilities of the officials. ${ }^{13}$

Giorgio Pastori indicates that the Constitution of the Italian Republic does not contain detailed rules setting out administrative procedure standards. ${ }^{14}$ The author points out that during the first two decades after the Second World War a number of legislative initiatives were undertaken to develop general regulations in the area of administrative procedure, but "not only such draft bills have never been approved by Parliament, but they were still based on the traditional idea according to which administrative procedures were only formal sequences of the preparatory acts for a final decision". ${ }^{15}$ As it was already mentioned that the principles contained in these constitutional provisions remained only a postulate for many years, not

12 The Constitution of the Italian Republic (La Costituzione della Repubblica Italiana) was enacted by the Constituent Assembly on 22 December 1947 and promulgated in Gazzetta Ufficiale on 27 December 1947. The Constitution came into force on 1 January 1948.

13 https://www.senato.it/documenti/repository/istituzione/costituzione_inglese.pdf (accessed: 14.02.2020).

14 G. Pastori, The Origins of Law No 241/1990 and Foreign Models, "Italian Journal Public Law" 2010, vol. 2, p. 261.

15 Ibidem, p. 262. 
supported by specific legal instruments strengthening the legal position of an individual in relation to the administration.

The adoption of the Administrative Procedure Act $^{16}$ in 1990 is considered to be an important change from the unilateral model of administrative decision making towards the participational one, through which attempts are made to reconcile the principle of transparency and effectiveness requirements. ${ }^{17}$ Gabriella Palmieri Sandulli notes the inherent flexibility of procedural rules contained in Law no. 241/1990, far from positivistic legal models. This evolution of Italian administrative law accentuates the role of the procedural legality (la legalità procedimentale) of administrative action. The Act assumes a pragmatic, functional and, in fact, discursive model of administrative proceedings. The above-mentioned author claims that:

A flexible application of the procedural rules according to the canons of rationality and proportionality allows to reconcile the guaranties for the administered with the efficiency of the administrative action and allows to find the balance between substantial legitimacy and the effectiveness of administrative action (il punto di equilibrio tra legittimità sostanziale e garanzia dello svolgimento efficace dellazione amministrativa)..$^{18}$

She adds, that it is not enough to act in accordance with the legal rules, the results of the proceedings should also be taken into account, overcoming the legal formalism ("Non basta agire secondo il modello legale, ma bisogna anche tener conto dei parametri di risultato, superando così la visione giusformalistica"). ${ }^{19}$

As Ian Stewart states,

What is considered to distinguish a "code" in this relatively strict sense from an ordinary statute is its combination of comprehensiveness and exclusivity: it contains all (or almost all) of the law, or all (or almost all) of a certain branch of the law. Both comprehensiveness and exclusivity, however, are found more often as aspiration than as achievement. ${ }^{20}$

Italian Law no. 241/1990 is by no means a code of administrative procedure, even if we take just the aspirations of its "founding fathers" into consideration. It cannot be compared to such the comprehensive, holistic and systematic regulations of the administrative procedure as those derived from the Austrian legal tradition, which exhaustively and in detail organise all (or almost all) aspects of

16 La legge 7 agosto 1990, n. 241 - "Nuove norme in materia di procedimento amministrativo e di diritto di accesso ai documenti amministrativi".

17 F. Lemetre, R. Miranda, Diritto amministrativo, Napoli 2015, p. 231.

18 G. Palmieri Sandulli, La riforma della legge n. 241/90 sul procedimento amministrativo, [in:] La Riforma della Legge N. 241/90 sul Procedimento Amministrativo. Atti della conferenza organiszata dalla Scuola Superiore dell'Amministrazione dell'Interno, Roma, 4 maggio 2005 - S.S.A.I., p. 27, http://ssaistorico.interno.gov.it/download/allegati1/legge241_90.pdf (accessed: 6.03.2020).

19 Ibidem.

20 I. Stewart, Australia, [in:] Codification of Administrative Procedure, ed. J.-B. Auby, Bruxelles 2014, p. 3. 
the administrative action. In spite of its obvious importance for the development of modern administration in Italy since 1990, it can be treated just as a framework regulation, encompassing only some countenances of the administrative procedure. F. Lemetre and R. Miranda argue that Law no. 241/1990 does not pretend to codify the entire structure and functions of administrative proceedings. Instead of this, it aims to limit discretionary power by specific legal institutions, ensuring the implementation of basic principles identified with the concept of good governance, that is: the principle of due process (il principio del giusto procedimento), the principle of transparency (il principio di trasparenza), the principle of simplification (il principio di semplificazione), the principle of correctness (il principio di correttezza) and the principle of good faith (il principio di buona fede). ${ }^{21}$

In Italy, it took over ten years to prepare a bill regulating administrative procedure. Works on the act began in 1979, as a special commission was appointed by Massimo Severo Giannini - Minister for the Civil Service. Mario Nigro became the chairman of the commission. Aldo Sandulli points out that Law no. 241/1990 was drafted by a small group of administrative law experts from academic circles that shaped the basic procedural institutions, using both the body of judicial decisions and comparative law findings. ${ }^{22}$ Other authors emphasize the strong tensions in scientific and political spheres during the elaboration of the act. G. Pastori points out that

the more traditional strains of la doctrine were sceptical about the adoption of an administrative procedure act, if not openly against it. Even some of the most distinguished scholars feared that the introduction of the principle of participation may lead to a further worsening of the Italian administration, which was already severely slow and inefficient. To this, we must add the hostility of politicians and civil servants towards a legislative framework based on the principle of fair procedure that would, at any rate, contribute towards limiting the arbitrary exercise of discretionary powers. ${ }^{23}$

In general, the commission's task was to create a normative act strengthening the principle of the Rule of Law (il principio di legalità) by removing barriers between an individual and the administration, providing legal institutions, ensuring individual participation in administrative procedure, simplification and transparency of administration. According to A. Sandulli, the procedural solutions introduced in the original text of Law no. 241/1990 were primarily aimed at providing elementary procedural guarantees to the individual. However, subsequent amendments to this act, motivated by ad hoc political needs, were mainly aimed at improving the efficiency of public administration, making the procedural position of an individual in disputes with the administration significantly weakened. ${ }^{24}$

21 F. Lemetre, R. Miranda, Diritto..., p. 232.

22 A. Sandulli, The Italian Administrative Procedure Act: Back to the Future, "Italian Journal Public Law" 2010, vol. 2, p. 202; http://www.ijpl.eu/assets/files/pdf/2010_volume_2/IJPL\%20 volume\%202_2010.pdf (accessed: 6.03.2020).

23 G. Pastori, The Origins..., p. 263.

24 A. Sandulli, The Italian Administrative..., p. 203. 


\section{Law no. 241/1990 - overview of the basic principles}

It should be noted that in Italian administrative law, the concept of administrative proceedings (il procedimento amministrativo) is clearly distinguished from the concept of judicial control of administrative action (il processo amministrativo). The first one concerns proceedings before administrative authorities of a noncontentious nature. It does not include judicial control over the activities of administration, the subject matter of which falls under the concept of "il processo amministrativo". ${ }^{25}$ Pursuant to Article 1 of Law no. 241/1990,

Administrative action shall pursue the objectives established by law ( $i$ fini determinati dalla legge) and shall be founded on criteria of the economy of action (economicita), effectiveness (efficacia), impartiality (imparzialità), publicity (pubblicità) and transparency (trasparenza), in accordance with the modes of action provided for both by the present Law and by the other provisions governing individual procedures, as well as by the principles underpinning the Community's legal order. ${ }^{26}$

The provision cited above lists the basic principles of administrative procedure, which are fully applicable to any public administration activity. It aims to implement the Rule of Law (il principio di legalita) into the level of administrative proceedings. It is worth mentioning that this principle is also applied when public tasks are carried out by private entities ("la disposizione chiede agli agenti amministrativi denominati munera di agire come farebbero gli agenti pubblici"). ${ }^{27}$ This is very important due to the growing phenomenon of privatization of public tasks, also occurring in Italy. ${ }^{28}$ When the requirements of the efficiency justify the delegation of tasks traditionally reserved for administration to private entities, the act guarantees that this type of functional delegation will not worsen the situation of those who are administrated.

Before the entry into force of Law no. 241/1990, an individual had not been provided with any procedural instruments to force an administrative authority to conclude the proceedings in the form of an explicit decision. The rules of a particular administrative action were often vague and an entity might not even be aware that any proceedings were pending. Article 2 of Law no. 241/1990 is to counteract these negative phenomena, strengthening the procedural rights of individuals by imposing the obligation to terminate proceedings within a statutory

25 It is regulated by: Il decreto legislativo 2 luglio 2010, n. 104 - Codice del processo amministrativo.

26 English translation of Legge 7 agosto 1990 n. 241 by Catharine de Rienzo, http://www.ijpl. eu/assets/files/pdf/leggi/Law\%20no\%20241-1990\%20-\%20for\%20publication\%20-\%20 25.03.2011.pdf (accessed: 6.03.2020).

27 M. Scanniello, Il procedimento amministrativo, Roma 2017, p. 74.

28 Ibidem, p. 73. 
period and in the form of an explicit ruling on the administration. This article states, that "Regardless of whether the procedure was initiated as a result of mandatory request (ad una istanza) or launched ex officio (d'ufficio), the public authorities shall have the duty to conclude it in the form of an express resolution (ladozione di un provvedimento espresso)".

In general, the administrative procedure falling within the competence of state or national public authorities has to be concluded within thirty days (devono concludersi entro il termine di trenta giorni). Under Article 2(6), "The timeframes for concluding procedures shall run from the beginning of an ex officio procedure or from receipt of an application (dal ricevimento della domanda), if the procedure is initiated by an interested party".

It should also be mentioned that the violation of provisions regarding the obligation to conclude the proceedings within the statutory deadline may result in the liability of administration for damages caused by missing the deadline ( $i l$ danno da ritardo). Pursuant to Article 2-bis(1), titled Conseguenze per il ritardo dellamministrazione nella conclusione del procedimento, "Public authorities and parties referred to in Article 1(1-ter) shall provide compensation for any unjustified loss or damage (danno ingiusto) caused by their intentional or negligent failure to observe (inosservanza dolosa o colposa) the timeframes for concluding a procedure". The obligation of concluding the procedure in the pre-established timeframes constitutes an aspect of the principle of legality, since it imposes the exercise of power in a reasonable time (l'esercizio del potere in tempi ragionevoli). ${ }^{29}$

A guarantee of no less importance, which was introduced by the discussed act, is the obligation of administrative authorities to motivate their measures (motivazione del provvedimento). According to Article 3(1), "The statement of reasons is to set out the factual premises (i presupposti di fatto) and points of law (le ragioni giuridiche) that determine the authority's decision, in accordance with what emerges from the preliminary fact-finding activities (istruttoria)". As Michelangelo Scanniello aptly observes, the justification of the decision has three essential functions: first, it provides the necessary information to enable the decision to be challenged effectively before the courts (delle informazioni indispensabili per laccesso al controllo giurisdizionale); second, it allows for a real control of the legality of the challenged act (un sindacato reale sulla legittimità dell'atto impugnato) to be made; third, it provides a procedural guarantee to ensure the transparency of the administrative body's actions (trasparenza dellazione amministrativa).$^{30}$

Articles 4 to 6-bis set the rules of responsibility for the conduct of proceedings. If it is not explicitly defined by the act or regulation, public authorities shall have the obligation to determine, "the organisational unit responsible for the preliminary fact-finding and every other kind of procedural activity, as well as for adopting 
the final measure for each kind of procedure relating to acts falling within their competence". It is an important procedural construction that disciplines administration and ensures its transparency. It can be regarded as a guarantee for an individual that the case will be dealt with, in person, by a specific official (a name of an official should be communicated at the beginning of a procedure). ${ }^{31}$ Therefore, specific administrative officials may be held liable for actions taken under their authority.

Chapter III of Law no. 241/1990 (titled: Partecipazione al procedimento amministrativo), consists of the rules which enable participation of an individual in the administrative proceedings. In accordance with Article 10, "The parties referred to in Article 7 and those who have intervened pursuant to Article 9 shall have the right: a) to inspect the procedure's documents (di prendere visione degli atti del procedimento), save as provided for under Article 24; and b) to present documents and written arguments (di presentare memorie scritte e documenti), which the authority has the duty to evaluate provided that they are pertinent to the object of the procedure".

Finally, without going into details, two original solutions of Italian administrative proceedings should be mentioned, namely: a services conference (conferenza di servizi $i^{32}$ ) and the "silence-equals-assent" principle (silenzio assenso ${ }^{33}$ ), included in the Chapter IV of Law no. 241/1990, titled Simplification of Administrative Action (Semplificazione dell'azione amministrativa).

\section{Conclusions}

The current concept of administrative proceedings in Italy has arisen in different way than in the Habsburg succession countries, based on its own solutions strongly influenced by French legal tradition. Apart from the obvious importance of Law no. 241/1990, the judicial control of administrative action seems to play in this country, as in France, a key role in the individual rights protection. The regulation of administrative proceedings in Law no. 241/1990 is by definition only a framework and does not implement the idea of full codification at all. It was intentionally conceived as a regulation based on principles intended to ensure the individual's participation in the procedure and its simplification. In spite of the widespread criticism of this act (in particular, its further amendments) in the Italian literature, one should agree with G.P. Sandulli that the adoption of Law no. 241/1990 has

31 Ibidem, p. 135.

32 See Article 14.

33 See Article 20. 
accelerated the process of deformalizing administrative law (il processo di deformalizzazione del diritto amministrativo), due to flexible and open structure of procedural norms (le norme procedimentali non sono omogenee, intangibili, ma hanno una struttura aperta)..$^{34}$ The Italian model of administrative proceedings, despite some imperfections, seems to be an interesting alternative to the Austrian one. It also makes us realise that every procedural regime - codified or not - is just an open work, therefore it is impossible to separate the law from the very process of its application and interpretation. It is open also in this sense, that every administrative proceedings act - like a work of art - should be always adapted to its future "respondents" challenges.

\section{Idea postępowania administracyjnego we Włoszech Opera aperta?}

Łatwość, z jaką większość krajów sukcesji habsburskiej recypowała wzory austriackie w zakresie kodyfikacji procedury administracyjnej, wiązać można ze stosunkowo łagodną, inkluzywną polityką Wiednia względem obszarów peryferyjnych. Instytucje prawne Cesarstwa Habsburskiego wrosły głęboko w tkankę polityczno-społeczną podporządkowanych terytoriów, stąd też po pierwszej wojnie światowej stanowily one naturalną podstawę do odbudowy porządków polityczno-prawnych w ramach państw narodowych powstałych na gruzach imperium. Na tym tle Włochy wyraźnie odróżniają się od innych krajów, na tereny których rozciągało się panowanie Wiednia. Austriacka władza zawsze traktowana była w północnej Italii jako ciało obce, w konsekwencji habsburska tradycja prawna nie zapuściła na Półwyspie Apenińskim głębokich korzeni. Odrzucenie spuścizny austriackiej, traktowanej jako obca i zewnętrzna, było dla Włoch gestem niejako naturalnym. Kształtując nowoczesny porządek administracyjnoprawny, Italia podążyła swą własną ścieżką rozwoju, na której odnaleźć można wyraźne ślady rozwiązań francuskich.

Kulturę prawa administracyjnego we Włoszech charakteryzuje wyraźna skłonność do administrowania za pomocą metod dyskrecjonalnych. Zręby procedury administracyjnej w Italii tworzyły się - podobnie jak we Francji - w ramach orzecznictwa sądowego. Przez długi czas wydanie aktu administracyjnego nie było poprzedzone transparentnym postępowaniem, w którym strona miałaby zapewniony czynny udział. Włoska doktryna od lat podkreślała wagę proceduralizacji prawa administracyjnego, wskazując, że w szczególności w przypadku wykonywania przez administrację kompetencji opartych na konstrukcji uznaniowości sam

34 G. Palmieri Sandulli, La riforma della legge n. 241/90..., p. 28. 
fakt przeprowadzenia postępowania oraz uzasadnienia decyzji ma dla jednostki fundamentalne znaczenie gwarancyjne.

Włochy bardzo późno, w istocie dopiero w latach dziewięćdziesiątych XX w., zaczęły wcielać w życie - za pośrednictwem konkretnych instytucji - ideę państwa prawnego. Kamieniem milowym w procesie proceduralizacji aktywności administracyjnej (la procedimentalizzazione dellattività amministrativa) było uchwalenie ustawy $\mathrm{nr} 241 \mathrm{z} 7$ sierpnia $1990 \mathrm{r}$. o postępowaniu administracyjnym i prawie dostępu do dokumentów urzędowych (Nuove norme in materia di procedimento amministrativo e di diritto di accesso ai documenti amministrativi). Do chwili wejścia w życie tego aktu normy wyznaczające konstytucyjne standardy w relacjach pomiędzy jednostką a władzą publiczną (sformułowane przede wszystkim w art. 97 Konstytucji Republiki Włoskiej z 1947 r.) pozostawały jedynie abstrakcyjnym postulatem.

Ustawa 241/1990 wpisywała się w szerzej zakrojony, ambitny projekt modernizacji włoskiej administracji, jednak nigdy nie aspirowała do rangi kodeksu. W zamierzeniu jej autorów (została przygotowana przez specjalną komisję ustawodawczą pod przewodnictwem Mario Nigro) miał to być akt prawny oparty na konstrukcji ogólnych zasad prawa, wprowadzający do włoskiego prawa administracyjnego instytucje prawne o elastycznym i pragmatycznym charakterze. Włoska doktryna, zgłaszając liczne uwagi krytyczne pod adresem tej ustawy, podkreśla równocześnie otwarty charakter zawartych w niej norm proceduralnych, nowoczesność przyjętych rozwiązań, ufundowanych - przynajmniej w pierwotnej wersji tekstu - na założeniu, że procedura administracyjna stanowi dyskursywny instrument prawny pozwalający pogodzić interes prywatny z interesem publicznym i wymogami skuteczności. Podkreśla się jednak słusznie, że kolejne nowelizacje włoskiej ustawy, dokonywane na przestrzeni lat głównie w celu zaspokojenia bieżących potrzeb politycznych, sprawiły, że koncepcja procedury administracyjnej zawarta w tym akcie oddaliła się od modelu opartego na zasadach i gwarancjach procesowych, ukierunkowując się głównie na zapewnienie administracji technicznie pojętej efektywności.

Maciej Wojtuń, Ph.D., Assistant Professor in the Department of Administrative Procedure - Faculty of Law and Administration, University of Łódź. 


\title{
Chapter VIII Poland
}

\author{
Joanna Wegner, Ph.D., Professor of University of Łódź \\ Department of Administrative Procedure \\ and a judge of the Voivodship Administrative Court in Warsaw \\ University of Łódź, Faculty of Law and Administration \\ jwegner@wpia.uni.lodz.pl
}

iD https://orcid.org/0000-0003-2773-6651

\section{The stages of the evolution of the law on administrative proceedings - from the first codification}

One may wonder how many codifications of the Polish administrative procedure there actually were. Following only the formal criterion, one could agree with the common view about two such legislative initiatives, first - the Regulation of the President of the Republic of Poland of 22 March 1928 on Administrative Proceedings, ${ }^{1}$ modeled on the draft of the Austrian Act of 1925 and then - of the Act of 14 June 1960 - Code of Administrative Procedure. ${ }^{2}$ The draft of the Austrian Act was translated into Polish in 1925 and published. ${ }^{3}$ This translation was taken under consideration by the Committee for Legislative Proposals for the Eastern Lands - subcommittee for removing discrepancies existing in particular acts on administrative proceedings, formed in the beginning of 1926 by the Presidium of the Council of Ministers. That body was to prepare the draft of the regulation on administrative proceedings, which was ready in $1926 .^{4}$

1 Dziennik Ustaw no. 78 , item 443 with amendments.

2 Dziennik Ustaw no. 30, item 168 with amendments.

3 It was published in the parts in four issues of a popular at that time legal newspaper, see: "Gazeta Administracji i Policji Państwowej" 1925, no. 9, pp. 201-203; no. 10, pp. 223-224; no. 11, pp. 245-246; no. 13, p. 295-296.

4 R. Hausner, Geneza rozporządzenia Prezydenta R.P. o postępowaniu adminsitracyjnem, "Gazeta Administracji i Policji Państwowej” 1933, no. 15, p. 499; E. Starczewski, Projekt ustawy o postępowaniu administracyjnem, ibidem, 1926, no. 23, p. 385; J. Borkowski, A. Krawczyk, [in:] System 
Only the abovementioned Regulation of 1928 and the Code of 1960 contained full regulation of general administrative proceedings in the history of Poland. However, many years ago, the view that as a code can only be defined an act, which plays the role of a pattern, defining the provisions of the legal system, was developed in the jurisprudence of the Constitutional Tribunal. ${ }^{5}$ Based on these premises, and also taking under consideration the content and purpose of re-enacting the procedural law in post-war Poland, contrary to the name given to it, it has already been raised in the legal doctrine as doubtful that the Code of Administrative Procedure was the second codification. If we compare the text of the Regulation of 1928 and the Code of 1960, it turns out that key procedural institutions were regulated almost identically, and the factor differentiating these acts in terms of content was the inclusion in the Code the regulation devoted to complaints and proposals, separation of general principles and entrusting the prosecutor as a participant with rights of a party.

Referring to the functional criterion, distinguishing the Code from other acts, as the next, after the pre-war, codification should be considered - as it was already mentioned in the literature - a deep amendment to the Code, which took place in 1980, although the Code still lacked of modern institutions, adequate to the needs of the administration of the late twentieth century. The amendment included, above all, reactivation of judicial review and adding to this act provisions regulating separate administrative proceedings: in matters of social insurance and matters of tax liabilities. ${ }^{6}$ New numbering of articles associated with it undoubtedly indicated that this act was refreshed, although the concept of the procedure itself, modeled on the idea of court proceedings, was not changed.

No features of codification had a significant - in terms of extensiveness - amendment of the Code, made in 1995, in connection with coming into force by the Act on the Supreme Administrative Court and the repealing of the Code provisions on proceedings before an administrative court. ${ }^{7}$ It was only to organize the new legal order. The codification features also cannot be attributed to an earlier amendment to the Code, the main purpose of which was to adapt it to new systemic conditions. ${ }^{8}$ Unlike other countries - the successors of the Austro-Hungarian monarchy, there was no new codification of administrative proceedings in Poland. It has

prawa administracyjnego. Prawo administracyjne procesowe, t. 9, eds. R. Hauser, Z. Niewiadomski, A Wróbel, Warszawa 2020, pp. 53-57; J. Borkowski, [in:] Polskie postępowanie administracyjne i sqdowoadministracyjne, eds. B. Adamiak, J. Borkowski, Warszawa 2001, p. 29.

5 Judgement of 18 October 1994 r., K 2/94, "Orzecznictwo Trybunału Konstytucyjnego" 1994, no. 2 , item 36.

6 Since 1 January 1998 the Act of 29 August 1997 - Tax Ordinance (Dziennik Ustaw 2019, item 900) has been regulating tax proceedings autonomously.

7 Act of 11 May 1995 on the Supreme Administrative Court (Dziennik Ustaw no. 74, item 368 with amendments).

8 Dziennik Ustaw no. 34, item 201 with amendments. 
some consequences for the development of the law on administrative proceedings, as discussed in more detail in the last paragraph of this chapter.

As it has been already raised in the legal doctrine, one may wonder whether a thorough amendment to the Code of $2017^{9}$ could be regarded as "unfinished" codification, as it resulted in a serious correction of the basic legal structures for the proceedings, e.g. administrative appeal and in introduction of new procedures and institutions, unknown to the Code before, such as simplified proceedings and tacit consent (administrative positive silence). ${ }^{10}$ However, this amendment was seriously delayed in relation to the needs of the legal system. The effect of "late codification" includes not only complications in the construction of procedural norms in particular categories of cases, but weakens the meaning of the Code itself, some parts of which remain dead in practice, prompting the question of the real significance of the provisions contained in this act. One may, of course, advocate, that the role of the Code has been transformed and it is becoming an act containing not only the provisions to be applied, but also those, which constitute a certain legislative pattern, setting out a way of regulating specific procedural institutions. ${ }^{11}$ The function of the act - template is, however, performed to a small extent. It would be difficult to indicate cases of using "legislative prescriptions" included in the Code, although it must be admitted, that only three years have passed since they came into force and that situation may change over time.

\section{The scope of the code on administrative proceedings binding force, including the problem of the subsidiary application of the provisions on general administrative proceedings}

The Polish Code of Administrative Procedure is not privileged in any way in the hierarchy of law sources, unlike it is, for example, within Dutch legal system. Article 3: 3 et seq. Dutch General Administrative Law Act $^{12}$ governs the relationship

9 Act of 7 April 2017 amending Code of Administrative Procedure and other laws (Dziennik Ustaw, item 935).

10 Z. Kmieciak, Postępowanie administracyjne na rozdrożu?, "Państwo i Prawo" 2019, no. 10, p. 19.

11 Z. Kmieciak, Zakres stosowania przepisów Kodeksu postępowania administracyjnego o milczącym załatwieniu sprawy, "Zeszyty Naukowe Sądownictwa Administracyjnego" 2019, no. 5, pp. 9-13.

12 Act of 2 April 1994 (Algemene wet bestuursrecht), https://wetten.overheid.nl/BWBR0005537/201904-02 (accessed: 9.12.2019); T. Barkhuysen, W. den Ouden, Y.E. Schuurmans, Netherlands, [in:] Codification of Administrative Procedure, ed. J.-B. Auby, Bruxelles 2014, p. 266. 
between the Code and separate provisions. However, the priority of applying the provisions of the Polish Code is derived from the Article 1 section 1 of this Act, stating a principle, according to which administrative proceedings in individual cases, conducted before public administration authorities, being concluded with administrative decisions or administrative silence are governed by the provisions of the Code. If this ground is out of the question, the application of the Code, usually to a limited extent, may take place as a result of a reference foreseen in substantive law. This kind of exclusive application of the Code is widely applied under the so-called third generation procedures. ${ }^{13}$

The abovementioned provision, does not exclude the introduction of separate regulations into the system. However, in the matters, which are not covered by such special provisions, the Code should be applied. In addition, all exceptions to the rule of applying the Code should be interpreted strictly (exceptiones non sunt extentendae). For this reason, the regulation of Article 1 section 1 of the Code is sometimes called an "invasive clause" in the doctrine. ${ }^{14}$ Its practical meaning can be described by the concept of subsidiary application, i.e. the application of the Code, whenever the conditions of Article 1 are fulfilled, and the special provision does not create any exception. ${ }^{15}$

Nowadays, indication an administrative case that could be dealt with without applying separate provisions seems impossible. The provisions of the substantive law limit or modify the application of the Code to a different degree. They consist of provisions excluding the application of the Code in whole or in part, which are often accompanied by variously constructed references. In this way, in particular categories of cases, autonomous procedures are created, under which the Code is not applied at all, or only partially. The use of the Code may also take the form of appropriate application, if the legislator clearly indicates this. As a result of such regulation, the person applying the law is then obliged to determine the scope of application of the Code's provisions in a given case: directly, with necessary modifications or not at all.

13 For example in art. 50 of the Act of 11 July 2014 on the principles of implementing programs in the field of cohesion policy financed in the financial perspective 2014-2020 (Dziennik Ustaw 2018, item 1431), which provides that while dealing with applications for funding and granting co-financing pursuant to the Act, the provisions of the Code of Administrative Procedure shall not apply, with the exception of provisions regarding the exclusion of employees of the authority and the method of calculating deadlines, unless the Act provides otherwise. At the same time, the same act "provides otherwise" in Article 45 subs. 4, pursuant to which, the provisions of section I chapter 8 of the Code of Administrative Procedure shall be used to provide information on the completion of the project evaluation and its result.

14 Z. Kmieciak, [in:] Kodeks postępowania administracyjnego. Komentarz, eds. Z. Kmieciak, W. Chróścielewski, Warszawa 2019, p. 665.

15 J.-B. Auby, General Report, [in:] Codification of Administrative..., pp. 12-13. 
It can be observed that special provisions often regulate basic structures for administrative proceedings, such as the form of settling the case or appeals, leaving the provisions of the Code to specify only technical and procedural rules, e.g. regarding deliveries, calls or deadlines. Therefore, the indicated, subsidiary application of the Code, turns out to be limited to issues less important for determining the material rights or obligations of the individual, although still important for the effectiveness of the actions taken in the proceedings.

\section{Characteristic institutions and peculiarities of law on administrative proceedings}

Among the institutions of the Polish administrative procedure, it would be difficult to indicate those, which are characterized by originality or values, that distinguish them from those already known in other legal systems. ${ }^{16}$ The key points of the Code are the institutions of the party and the administrative decision. They are supplemented by a traditional, hierarchical concept of administrative appeal, amended in 1980 by introducing a non-devolutive appeal - an application to reconsider the matter. ${ }^{17}$ Until the reactivation of the judicial review in 1980, the appeal was, in principle, the only legal remedy which, apart from extraordinary procedures, could be directed against the administrative decision.

A peculiarity of the Code is that, since its amendment in 1980, the formula of one-instance administrative proceedings in substantive civil matters in the field of social security has developed. They are solved by the administrative authorities whose decisions are subject of the appeal to a common court, having various instruments counted as merits review. ${ }^{18}$ Recent amendments of the Code also cannot be described as innovative, since they are modeled on those, that have been operating abroad for a long time. Regardless of historical or political conditions, creating the law on administrative proceedings is strongly influenced by foreign systems. The lack of new codification after the political changes of the end of the 20th century did not stop the development of this law. The imperfections and shortcomings of the Code are compensated by "fragmentary" amendments to this act and separate regulations. Some of the new procedural institutions, such as the silence of administration (tacit consent) and the simplified procedure were finally added to the Code; others - as exemplified by the administrative contract or mass proceedings - are still waiting for it.

16 See Z. Kmieciak, Poland, [in:] Codification of Administrative..., p. 337.

17 Z. Kmieciak, Odwołania w postępowaniu administracyjnym, Warszawa 2011, p. 118 and following.

18 Ibidem, p. 168. 


\section{The relation between legal institutions on administrative proceedings and the model of judicial review}

Although the judicial review system has since 2004 been determined by the principle of two instances and the scope of judicial review is broadly defined, the key institutions of the judicial process, primarily adjudication and evidence proceedings, seem to be quite archaic. Opening the procedure before the administrative court depends on prior administrative proceedings and, as a rule, exhaustion of available legal remedies - Article $52 \$ 1$ of the Act of 30 August 2002 - Law on Proceedings before Administrative Courts (hereinafter: p.a.c.). ${ }^{19}$ Opening the court proceedings blocks the possibility to annul the decision under the extraordinary administrative procedures, and if such administrative proceedings were initiated earlier, the court procedure is to be suspended. The scope of the evidence constituting the basis for the administrative court's judgment is determined strictly by the administrative case file, which is stipulated in Article 134 p.a.c.

The evidence proceedings before an administrative court is limited to the minimum, since, pursuant to Article $106 \$ 3$ of the p.a.c., only documentary evidence, in a narrow, complementary extent is permitted. This regulation is closely related to the court's competence, basically limited to the cassation formula, modeled on the type formed in the jurisprudence of the Austrian-Hungarian Supreme Administrative Court in the second half of the 19th century. Exceptions to this are few and, apart from the court's discontinuation of administrative proceedings, they are rarely used. The administrative authority, which reconsiders the case remains, pursuant to Article 153 p.a.c., bound by legal assessment and guidelines for further proceedings included in the adjudication eliminating the contested decision. In the opinion of $\mathrm{Z}$. Kmieciak, the indications regarding further proceedings, placed in the justification of the judgment granting the complaint, may be treated as the weaker or hidden form of the order addressed to the administrative authority. ${ }^{20}$ These recommendations are absolute; their violation may result in imposition of a fine on the administration, in the retrial before the court, on the complaint of failure to comply with the judgment.

As a result of the amendment to the Law on Proceedings before Administrative Courts of 2015, the relationship between the cassation adjudication and the result of a re-conducted administrative procedure changed slightly. The court, in addition to annulling the decision, may oblige the authority to issue a decision within

19 Dziennik Ustaw 2019, item 2325.

20 Z. Kmieciak, O merytorycznym orzekaniu przez sądy administracyjne raz jeszcze, "Gdańskie Studia Prawnicze" 2015, no. 4, pp. 11-32. 
a specified time limit, indicating the manner of settling the case or its settlement. In this case, the competent authority is obliged to notify the court within seven days of issuing such a decision. Failure to fulfill this obligation is connected with the possibility of imposing a fine on the authority and gives rise to the applicant's right to submit a further complaint, with a request to issue a judgement confirming the existence or non-existence of the right or obligation. Having regard to the complaint in such a case, the court determines whether not issuing the decision took place in gross violation of law and may also, ex officio or at the request of the party, impose a fine on the authority or grant compensation to the applicant.

An appeal to an administrative court may be accompanied by a request for temporary protection of suspending the execution of the contested act. The effect of granting this request is, according to Article $152 \$ 1$ of the p.a.c., inadmissibility of the act execution, until the final termination of the court proceedings.

\section{The influence of the Austrian codification idea on the shape of contemporary legal solutions}

The Polish Code of Administrative Procedure is still strongly influenced by the Austrian patterns. The jurisdictional type of administrative procedure, the key features of its institutions, i.e. parties to proceedings, administrative decisions and administrative appeals remained unchanged for almost hundred years. The consolidation of the pre-war ideas, modeled on Austrian legislation demonstrates their universality. It turned out that they were also useful under the totalitarian system. In the current legal order, the provisions of the Code, apart from marginally applied in practice administrative settlement and, added in 2017, administrative silence (tacit consent), do not provide any other forms of concluding the case. The administrative appeal and non-devolutive application to reconsider the matter still remain legal remedies against the administrative decision. On the other hand, separate provisions limit the admissibility of an appeal in some cases, in favor of the right to initiate judicial review directly. Equally well established in the Polish system is the idea of judicial review taken over from the Austrian system, with the principle of cassation adjudication. The Polish legal order is still based on the Austrian model, although modern procedural institutions sometimes appear, an example of which is mediation, admissible both in administrative proceedings and in proceedings before administrative court. 


\section{The impact of European law on the activities of the national legislature and judicature}

Undeniably, the Polish legal order and adjudication are influenced by European law. The principle of procedural autonomy reserved for national systems is currently opposed by those norms of EU law that increasingly determine national procedural regulations. This is not about interference in this autonomy, which is based on the need to ensure the effectiveness of the application of European substantive law and the principle of equivalence, prohibiting the establishment of national provisions discriminating matters governed by EU law. ${ }^{21}$ In addition to derived from values common to the Member States, procedural standards, which have already been described many times in the doctrine and applied by Polish administrative courts, more and more secondary regulations appear, providing specific procedural institutions or whole procedures, addressed to national administration. ${ }^{22}$

Also at the intersection of EU and national order, the abovementioned subsidiary application of the Code appear. This time it refers to the relationship between the provisions of this act and the provisions of EU law, due to the principle of priority of the latter. An exemplification of this phenomenon is the institution of positive silence of administration (tacit consent). The procedure leading to this form of settling the case in some categories of cases is harmonized by EU law, for example those remaining under the regulation of the Directive 2006/123/EC of the European Parliament and of the Council of 12 December 2006 on services in the internal market ${ }^{23}$ or Directive 2005/36/EC of the European Parliament and of the Council of 7 September 2005 on the recognition of professional qualifications. ${ }^{24}$ They create, unknown to the Code, obligations of administrative authority to confirm receiving of the request, indicate the deadline for settling the case and inform the party about the possibility of settling the case by positive silence and available legal means. Also, in contrast to the absolute regulation of Article 122a $\$ 1$ of the Code, the deadline for settling the case may be extended by the administrative authority once. The applicant must be notified about those obligations. The lack of an act implementing the abovementioned EU provisions in the Polish legal order enables applying the provisions of the directive, since they meet the criteria of the Van Gend \& Loos test. It also justifies the idea presented in the adjudication of

21 Z. Kmieciak, Postępowanie administracyjne i sq̨dowoadministracyjne a prawo europejskie, Warszawa 2009, pp. 24-28.

22 Z. Kmieciak, Wstęp, [in:] Postępowanie administracyjne w Europie, ed. Z. Kmieciak, Warszawa 2010, p. 13; J. Chlebny, Standardy Rady Europy i Europejskiego Trybunału Praw Człowieka, [in:] ibidem, p. 24.

23 Official Journal L 376, 27 December 2006, pp. 0036-0068.

24 Official Journal L 255, 30 September 2005, pp. 0022-0142. 
administrative courts of the need for subsidiary application of the provisions of the Code in relation to directly applicable EU provisions. ${ }^{25}$

Particularly worth mentioning is the fact that the shortcomings and deficiencies of procedure before administrative courts, described in previous parts of the chapter, may conflict with the increasingly demanding requirement of the CJEU to decide effectively in certain categories of cases. The Polish procedural law does not provide solutions enabling merits review formula outlined by the CJEU in $\S 74-76$ of the judgment of 29 July 2019 , C-556/17 in the Tubarov case ${ }^{26}$ and in earlier issued ones, among others in the judgment of 5 June 2014, C-146/14, in the case of Mahdi ${ }^{27}$ and the judgment of 25 July 2018, C-585/16, in the case of Alheto. ${ }^{28}$ These rulings correspond with the raised for years in the legal doctrine postulate of freeing the administrative court from the restrictions of cassation verdicts in favor of introducing the possibility of merits adjudication, although it is debatable whether the court should be empowered to replace the administrative authority's decisions. It is worth mentioning that, regardless of the need to reform the proceedings before administrative courts and providing the court with the competence of merits review, such competence would be justified by the low efficiency of adjudication and the associated length of proceedings in administrative cases. ${ }^{29}$

\section{Openness to innovation - does the tradition or the modernization aims prevail in the actions of the legislature activities?}

The activity of the national legislator could hardly be characterized by the desire to add modern institutions into the Code, although the provisions of this Act have been subject to amendments for many years. The new Code regulations are, however, little operative, which is the result of the lack of further legislative initiatives, late intervention of the legislator, which is not accompanied by actions adapting the existing provisions of the Code, as well as creating numerous exceptions to the

25 See judgements of Voivodship Administrative Court in Warsaw of 7 August 2019, VI SA/Wa 702/19 i VI SA/Wa 768/19, www.orzeczenia.nsa.gov.pl (accessed: 15.02.2020).

26 EU:C:2019:626.

27 EU:C:2014:1320.

28 EU:C:2018:584.

29 Z. Kmieciak, O merytorycznym orzekaniu..., p. 11-32; idem, Efektywność sqqdowej kontroli administracji publicznej, "Państwo i Prawo" 2010, no. 11, p. 21 and following. Contrary see for example A. Skoczylas, W. Piątek, Kasacyjny czy merytoryczny model orzekania - kwestia zmiany modelu sądowej kontroli decyzji administracyjnych, ibidem, 2019, no. 1, pp. 24-38. 
Code regulations. Such activity of the legislator, introducing imperfect institutions into the system, provokes the question about the sense of such actions. At least a few new institutions may be identified within the Code, which may contribute to fastening the proceedings, easing the administration with carrying out its tasks, which, however, cannot be applied, due to restrictions, resulting from some kind of constructive gaps in the system or lack of well organization within the separate regulations. Therefore, certain process regulations remain continuously in statu nascendi phase, without real prospects for use in practice. This apparent unfinished legislative process is deepening in longer and longer period of the legislator's inactivity in the implementation of announcements of its own legislative activities.

On the other hand, the modification of the institution of the application to reconsider the matter, which has become an optional measure (either a complaint to the court or a request) deserves a positive assessment. Earlier, its submission was determining the admissibility of lodging a complaint to the administrative court. Currently, the effect of submitting the application is - according to Article 54a $₫ 1$ and 2 of the p.a.c. - temporary inadmissibility of initiating judicial review, until a decision is issued as a result of submitting this legal measure. Separate regulations also deserve a positive assessment, as they respond to the need for efficient settlement of specific categories of cases, for example the procedure regulated in Chapter $5 \mathrm{Ad}$ ministrative proceedings for investments in the construction of a nuclear power facility of the Act of 29 June 2011 on preparation and implementation of investments in the field of nuclear power plants and associated investments. ${ }^{30}$ Also the inclusion of mediation provisions in the Code in 2017 should be counted as its positive amendment. The scope of cases, in which mediation is admissible is broadly defined - it can be conducted in any case, whose nature allows it. Mediation can be carried out not only in a case, in which a dispute exists between the parties, but also in those between the party and the administrative authority. This institution is not - so far - a popular tool of dealing with individual cases, however, the reasons for this situation should be seen in the attitude of officials not accustomed to using alternative dispute resolution, rather than in deficiencies within the regulation.

\section{Codification of administrative proceedings and de-codification trends}

The phenomenon of de-codification, known to all legal systems, has been criticized for a long time in the Polish doctrine, which seems not to notice, that we are dealing with a phenomenon that is inevitable today, already noticed by the pre-war

30 Dziennik Ustaw 2018, item 1537. 
legislature. It is proved by the text of Article of 1 Regulation of 1928 on administrative proceedings, which reserved the possibility of establishing exceptions to the application of that act, announcing them in its text or in separate provisions. Unlike its pattern, the Code of Administrative Procedure does not provide such possibility, which, of course, does not exclude it. The presented in the doctrine point of view appears to be a consequence of the assumption, adopted by the framers of the Code, that it would remain an universal Act, with no exceptions. This idea was expressed in the draft, indicating that it is to "replace the existing separate provisions on administrative proceedings, which, in many cases no longer meet the current conditions". ${ }^{31}$

The reality strongly verified this assumption, showing that the vision of the authors of the Code's draft was too idealistic. The necessity of carrying out ever new categories of public tasks forced the introduction of numerous exceptions from the Code regulations. In a system where, however, there is still a tradition of applying the Code, this situation may raise doubts as to the relationship between the Code and the separate provisions. ${ }^{32}$ Their multitude makes one wonder whether the need to regulate the procedure in one legal act, which is currently advocated by some representatives of the doctrine, would be even possible. It would require a significant effort of the legislator, who would be to arrange existing provisions, eliminate those, which are unnecessary, and - in addition - resign from regulating the procedure outside the Code. The development of a new Code could therefore not lead to the unification of procedures, but rather - as it was already noticed in the legal doctrine - to preparing a framework, serving as a model for subsequent legislative activities.

\section{Codification of administrative proceedings and practice}

The scope and intensity of application of particular Code institutions are varied. The adoption of the Code in 1960 was not accompanied by the reactivation of judicial review, which significantly made it difficult to present coherent views regarding the interpretation of the provisions of this act. Application of some of these provisions in administrative practice was limited or even negligible, an example of which is

31 Komisja do opracowania projektu przepisów o postępowaniu administracyjnym, Projekt kodeksu postępowania administracyjnego, Warszawa, kwiecień 1959, p. 50.

32 Z. Kmieciak, Postępowanie administracyjne na..., pp. 6 and following; idem, Słowo wstępne, [in:] Raport zespołu eksperckiego z prac w latach 2012-2016. Reforma prawa o postępowaniu administracyjnym, ed. Z. Kmieciak, Warszawa 2017, p. 12. 
regulation of the Article $8 \$ 1$ of the Code, referring to the principle of trust. It could be observed that the provisions of the Code began to gain universally respected significance only after reactivation of judicial review. Some of the Code provisions even "came to life" from that moment. It was the court's case-law that gave the principle of trust real sense for administrative proceedings, seeing in it the sources of procedural claims. From the abovementioned principle were for example derived: the prohibition of law abuse by the administration or ex officio actions in a matter requiring the party's request, the obligation to direct necessary instructions to the party in such a way that the party does not suffer from ignorance of the law and to explain the content of the party's request, if the actual intention the author of the request is questionable, friendly interpretation of the claims, based on their actual intentions, and not the form, using the institution of fiction, which was well known to Roman law, to protect values considered as particularly momentous. ${ }^{33}$

\section{Successes and failures - what was not achieved?}

The fate of the Polish law on administrative proceedings, as elsewhere, includes both successes, which undoubtedly was its first codification of 1928 , as well as failures. To the latter we may certainly count a failed attempt of addition to this act of provisions on an administrative agreement. Responding to the formulated for years postulate of the doctrine, a draft of provisions on the administrative contract, which was to be added to the Code was prepared in a report on the work of the expert group on the reform of Law of Administrative Procedure in the years 2012-2016 led by prof. Z. Kmieciak. Ultimately, however, this part of the draft was not taken under consideration in the Act amending the Code of 2017. According to the draft, the contract was modeled on the German subordination contract (arrangement), excluding the one, called an exchange contract..$^{35}$ Polish administration

33 E. Łętowska, Commentary to the judgement of Supreme Administrative Court of 1 July 1999, SA/Bk 208/99, "Orzecznictwo Sądów Polskich" 2000, no. 1, p. 17 and following, judgement of Voivodship Administrative Court in Warsaw of 13 July 2004, I SA 3093/02, LEX no 158855, judgement of Supreme Administrative Court of 18 February 1994, SA/Wr 1587/93, "Prokuratura i Prawo" - wkładka 1995, no. 2, p. 54, judgement of Voivodship Administrative Court in Gdańsk of 8 September 2010, II SA/Gd 279/10, LEX no 752437, judgement of Supreme Administrative Court of 12 May 2000, III SA 957/99, "Orzecznictwo Sądów Polskich" 2001, no. 9, item 131.

34 Established by the order No 8 of the President of the Supreme Administrative Court of 10 October 2012.

35 A. Krawczyk, [in:] Raport zespołu..., pp. 159-160. 
closes contracts in the course of carrying out public tasks. However, deficiencies in procedural administrative law regulations prompted court rulings to submit claims based on obligations arising from administrative contracts to the civil law regime and the jurisdiction of common courts. This is obviously a flawed solution, especially when it comes to the legal basis for the claims, derived from private law and creates the risk of distorting the essence of this particular kind of contract as a result of civil court proceedings.

An attempt to return to the pre-war idea of access to proceedings for other than the parties individuals, also failed. Such concept, which has its origin in the Article 9 section 1 of the 1928 Regulation, was materialized in the draft Article 31a of the Code of Administrative Procedure. ${ }^{36}$ It was to enable interested entities, who were not parties or holding party rights, to present their view on a case in writing, that would be attached to the case files and to provide such individuals with access to the files. This regulation - according to the group's report - was to favor conciliatory settlement of cases, and also to fulfill the demand for broad participation, characteristic of contemporary administrative procedures. ${ }^{37}$ What also failed was an attempt to include the provisions on general administrative act or mass proceedings in the code. The still unsolved problem remains the length of proceedings, combined of both: the administrative and courts procedure. It is a common situation that it takes about 6-8 years to receive a final decision as a result of the enforcement of a final court adjudication.

\section{General conclusions and comments on the development prospects of law on administrative proceedings}

It seems that the optimal "moment of codification", after the political changes of the end of the 20th century in the Polish system, has already passed. It did not happen either in the 1990s or after Poland's accession to the European Union in 2004, which means neglecting the opportunity to prepare an act meeting the contemporary systemic needs. The lack of a modern procedural law has not stopped other ways of introduction of the necessary procedural institutions or even entire

36 Also prepared by the expert group on the reform of Law of Administrative Procedure.

37 Ultimately, this proposal was not included in the draft no. 1183 of the Sejm of the 8th term. On this topic, see J. Barnes, Towards a Third Generation of Administrative Procedure, [in:] Comparative Administrative Law, eds. S. Rose-Ackreman, P.L. Linseth, Cheltenham-Northampton 2010, p. 342 and following. 
procedures into the system, in order to enable administration to deal with increasingly diverse public tasks. Large number of special regulations is applied to almost all matters handled by the administration, determining the rules of administrative procedure to varied extent.

Although, under the derived from Article 1 section 1 of the Code clause, the provisions of this Act must be applied in a subsidiary way, if nothing else results from separate regulations, the intensity of de-codification limits the application of the Code significantly. In many proceedings, only those provisions of the Code are applied, which are specifically mentioned in separate provisions. It was already mentioned in the legal doctrine, that the relation between the Code and special provisions has been reversing. The use of the latter becomes the rule, and the code - the exception.

These phenomena is not eliminated by the legislator's attempt to modernize the Code by introducing into it institutions previously unknown to this Act. Petrification of some of them in separate provisions within the framework of autonomous procedures does not allow the full use of the Code's potential. Separate provisions leave little space for making use of its new provisions. It is undoubtedly difficult to apply this complex regulation. In turn, these modern institutions, which have not yet been regulated in the Polish law on administrative proceedings, for example, mediation, hardly break through the resistance of the administration not accustomed to them. These institutions - such as an administrative contract, general administrative act or mass procedure - which need to be regulated have been unanimously pointed out, by both legal doctrine and practice, are still waiting to get Code provisions.

It was already noticed in the legal doctrine, that the real role of the Code in the domestic legal order is not easy to be defined and it would be difficult to answer the question about the meaning of this act. Conclusions in this regard must take into consideration the particular categories of cases. Depending on their nature, the role of the Code changes. It can be seen, that the provisions of this act are usually more widely applied in those cases, which are dealt with traditional procedural institutions. However, in those cases, whose resolution requires modern types of procedures or that go beyond the traditional legal framework, the provisions of the Code are displaced by separate provisions.

The conclusion is that, the Code stopped to play the role of governing administrative proceedings act long time ago. Certainly it constitutes a certain base, which the legislator still uses while constructing separate procedures. These include, in particular, regulations devoted to technical and procedural activities, such as deadlines or deliveries. However, the course of the administrative procedure with a decision-making form of case conclusion and extensive procedural guarantees has no more been attractive to the legislator, struggling with the need to provide administration with appropriate procedural tools. It turns out, therefore, that the operability of individual Code institutions is heterogeneous. We may predict, that in the future the native system will be dominated by special provisions, marginalizing the Code regulation. 
As it was already raised in the literature, it is worth considering developing a new Code, although it would be a complicated and time-consuming task in the current state of the legal system. After all, this would require a review of separate regulations in order to design new regulations properly and modify or repeal others, to minimize the need to use non-code regulations. It is doubtful whether the legislator is able to undertake such a task. It is impossible to expect such an initiative from the administration, because this overloaded machine would have to bear the additional burden of preparing such a project. Therefore we are dealing with some kind of a stalemate in Poland; a new legal act with the rank of the Code is certainly needed, but there are little chances of its adoption. On the other hand, the Code, despite many amendments, no longer meets its expectations. Therefore, the prospects for the development of the Polish administrative procedure are vague, complicating the task of theoretical description of so varied legal order.

\section{Polska}

W literaturze naukowej stawiane jest ostatnio pytanie: ile razy dokonano u nas rzeczywistej kodyfikacji postępowania administracyjnego. Kierując się tylko kryterium formalnym, można byłoby zgodzić się z twierdzeniem o dwóch takich przedsięwzięciach legislacyjnych, dokonanych najpierw w drodze wzorowanego na projekcie ustawy austriackiej z 1925 r. rozporządzenia Prezydenta Rzeczypospolitej z 22 marca 1928 r. o postępowaniu administracyjnem, a następnie ustawy z 14 czerwca 1960 r. - Kodeks postępowania administracyjnego. Jeżeli porównamy teksty tych aktów, to okaże się, że kluczowe instytucje procesowe zostały w nich uregulowane niemal identycznie, a czynnikiem odróżniającym te unormowania było przede wszystkim włączenie do kodeksu przepisów dotyczących skarg i wniosków, wyodrębnienie zasad ogólnych oraz udziału w postępowaniu prokuratora jako podmiotu na prawach strony.

Polski kodeks pozostaje nadal pod silnym wpływem unormowań austriackich. Cechy konstrukcyjne węzłowych dla niego instytucji, np. strony postępowania, decyzji administracyjnej i odwołania, pozostały w zasadzie niezmienione od niemal 100 lat. Wciąż zdominowane przez XIX-wieczne wzorce austriackie okazują się także kluczowe instytucje postępowania przed sądem administracyjnym. Wprawdzie ustrój sądownictwa administracyjnego od 2004 r. zdeterminowany jest przez zasadę dwuinstancyjności, a zakres sądowej kontroli ujęty jest szeroko, jednak samo postępowanie cechuje archaizm i nieadekwatność do potrzeb współczesnych wymagań efektywnego sprawowania sądowej kontroli.

Odwołując się do odróżniającego kodeks od innych ustaw kryterium funkcjonalnego, za kolejną, po przedwojennej, kodyfikację należałoby uznać głęboką 
nowelizację kodeksu, która miała miejsce w 1980 r. Jest kwestią dyskusyjną, czy gruntownej zmiany przepisów kodeksu z 2017 r. nie należy traktować jako kolejnej, choć niedokończonej kodyfikacji. W jej wyniku doszło do poważnej korekty podstawowych dla postępowania konstrukcji prawnych, np. odwołania oraz wprowadzenia nieznanych dotąd kodeksowi nowych procedur, trybów i instytucji, takich jak postępowanie uproszczone i milczące załatwienie sprawy. Nastąpiło to jednak ze zwłoką w stosunku do potrzeb systemu prawnego. Wywołany w ten sposób efekt „spóźnionej kodyfikacji” obejmuje nie tylko komplikacje w konstruowaniu norm procesowych w poszczególnych kategoriach spraw, ale osłabia znaczenie samego kodeksu. Niektóre jego części pozostają martwe w praktyce, skłaniając do postawienia pytania o realne znaczenie zawartych w tym akcie przepisów. Wydaje się, że $\mathrm{w}$ rodzimym systemie minął już optymalny, po przemianach ustrojowych z końca XX w., „moment kodyfikacji”. Nie zdecydowano się na to ani w latach dziewięćdziesiątych XX w., ani po przystąpieniu Polski do Unii Europejskiej w 2004 r., tracąc sposobność przygotowania aktu odpowiadającego potrzebom współczesności.

Otwierający regulację kodeksową przepis art. 1 k.p.a. nie wyklucza wprowadzania do systemu uregulowań odrębnych, ale w kwestiach, które nie są objęte przepisami szczególnymi stosować należy unormowania kodeksowe. Praktyczny sens „klauzuli inwazyjnej” ustanowionej w art. 1 pkt 1 i 2 daje się opisać za pomocą pojęcia subsydiarnego stosowania kodeksu, a więc stosowania go w każdym przypadku, gdy są spełnione wskazane w tym przepisie przesłanki, a przepisy szczególne nie wprowadzają odstępstw. Zawarte $\mathrm{w}$ ustawach prawa materialnego przepisy w różnym stopniu ograniczają bądź modyfikują zastosowanie kodeksu. W ten sposób, w poszczególnych kategoriach spraw, tworzone są procedury autonomiczne, w ramach których kodeks nie znajduje w ogóle zastosowania albo stosowany jest fragmentarycznie.

Rzeczywista rola kodeksu w rodzimym porządku prawnym jest niełatwa do zdefiniowania i trudno byłoby jednoznacznie odpowiedzieć na pytanie o znaczenie tego aktu. Ustalenia w tym przedmiocie muszą uwzględniać kategorie spraw, z którymi mamy do czynienia. W zależności od ich charakteru zmienia się funkcja kodeksu. Można zauważyć, że przepisy tego aktu znajdują zwykle szersze zastosowanie $\mathrm{w}$ tych sprawach, które załatwiane są z wykorzystaniem tradycyjnych instytucji właściwych postępowaniu jurysdykcyjnemu. Natomiast w tych sprawach, których rozstrzygnięcie wymaga nowoczesnych typów procedur albo wykraczających poza tradycyjny schemat konstrukcji prawnych, przepisy kodeksu wypierane są przez rozwiązania zamieszczone w przepisach odrębnych.

Przyjmuje się w związku z tym, że kodeks dawno już przestał pełnić przypisywaną mu rolę aktu rządzącego postępowaniem administracyjnym. $\mathrm{Z}$ pewnością stanowi on pewną bazę, którą ustawodawca wciąż wykorzystuje, konstruując procedury odrębne. Do nich zaliczają się w szczególności uregulowania poświęcone czynnościom techniczno-procesowym, jak wezwania, terminy czy doręczenia. Niemniej sam tok kodeksowego postępowania jurysdykcyjnego z decyzyjną formą 
załatwienia sprawy i rozbudowanymi gwarancjami proceduralnymi przestał już być atrakcyjny dla ustawodawcy, zmagającego się z koniecznością zapewnienia administracji właściwych narzędzi procesowych. Okazuje się zatem, że operatywność poszczególnych instytucji kodeksowych jest niejednorodna. Nie jest wykluczone, że w przyszłości system rodzimy zostanie zdominowany przez przepisy szczególne, marginalizując regulację kodeksową.

Warto zastanowić się nad przygotowaniem projektu nowego kodeksu, choć byłoby to $\mathrm{w}$ aktualnym stanie systemu prawnego zadanie skomplikowane i czasochłonne. Wymagałoby ono przecież przeglądu uregulowań odrębnych w celu właściwego skonstruowania nowych przepisów i zmodyfikowania bądź uchylenia innych, by ograniczyć do minimum potrzebę korzystania z unormowań pozakodeksowych. Można mieć uzasadnioną wątpliwość, czy ustawodawca jest w stanie podjąć się takiego zadania. W pewnym sensie więc w Polsce mamy do czynienia z sytuacją patową; nowy akt prawny o randze kodeksu jest z pewnością potrzebny, ale nikłe są szanse jego uchwalenia. Z kolei ustawa z 1960 r. nie spełnia już stawianych jej oczekiwań, mimo dokonywanych ustawicznie nowelizacji. Perspektywy rozwoju polskiego postępowania administracyjnego rysują się więc niejasno, komplikując stawiane nauce prawa zadanie teoretycznego opisu coraz bardziej złożonego porządku prawnego.

Joanna Wegner, Ph.D., Professor of the University of Łódź, the Department of Administrative Procedure - Faculty of Law and Administration, University of Łódź, and a judge of the Voivodship Administrative Court in Warsaw. Member of the expert group on the reform of Law of Administrative Procedure in the years 20122016 led by prof. Z. Kmieciak. The activities of this group have made a contribution into essential modernization of the Polish Code of Administrative Procedure in 2017. 



\section{Chapter IX Serbia}

Dejan Vučetić, LL.D.

Associate Professor of Administrative Law

The University of Niš, Faculty of Law

dvucetic@prafak.ni.ac.rs

iD https://orcid.org/0000-0002-9140-5251

\section{Stages in the evolution of the law on administrative procedures - from the first codification}

During its turbulent history over the past two centuries, modern Serbia has gone through different states and forms of government: the Principality of Serbia, the Kingdom of Serbia, the Kingdom of Serbs, Croats and Slovenes and the Kingdom of Yugoslavia, the Democratic Federative Yugoslavia (DFY), the Federative People's Republic of Yugoslavia (FPRY), the Socialist Federative Republic of Yugoslavia (SFRY), the Federal Republic of Yugoslavia (FRY), the State Union of Serbia and Montenegro, and the Republic of Serbia.

For the first time, Serbian administrative procedure rules were formally codified during the Kingdom of Yugoslavia (between the First and the Second World War), which at that time included Croatia, Serbia, and Slovenia. This period is thoroughly explained in Chapter IV, which also covers another period in the development of administrative procedure law during the socialist regime in Yugoslavia (after the Second World War). After the dissolution of the SFR Yugoslavia at the end of the 20th century, Serbia basically used the adjusted versions of the Yugoslav GAPA until 2016, when the new redesigned version of the General Administrative Procedure Act (GAPA 2016) was adopted. ${ }^{1}$ Thus, the third period in the development of administrative procedure in Serbia started in 2017 when the new Serbian GAPA fully entered into force.

1 Zakon o opštem upravnom postupku (General Administrative Procedure Act), Službeni glasnik RS br. 18/2016 i br. 95/2018-autentično tumačenje. 


\section{The binding force of the law on administrative procedure and the issue of subsidiary application of provisions regarding the general administrative procedure}

As widely discussed in the administrative law literature, the binding force of the GAPA has three dimensions: territorial scope, temporal validity, and the subjects applying it. ${ }^{2}$ In the context of our analysis, the most important dimension is the one according to which public authorities are obliged to act upon the GAPA rules. According to Article 1 of the Serbian GAPA (2016), those include state authorities and organizations, authorities and organizations of provincial autonomy, authorities and organizations of local self-governments, institutions, public enterprises, special authorities which exercise the regulatory function, and legal and natural persons entrusted with (delegated) public powers. In the subsequent parts of the GAPA, all these subjects are designated as authorities. Accordingly, this designation will be used throughout the Chapter. Under the provisions of Article 1 of the GAPA, those authorities apply the GAPA rules when they act in administrative matters. The administrative matter is defined in the 2016 GAPA for the first time, but in very broad terms, which will be discussed in more detail in point 3 of this Chapter.

Regarding the subsidiary application of the GAPA rules on special administrative procedures, it follows the theoretical division of Serbian administrative procedures into general and special procedures. ${ }^{3}$ The special administrative law provisions are provided in special laws that regulate specific areas of public activities and subject matters. According to Article 3 ( $\$ 2$ ) of the GAPA, some issues of administrative procedure may be regulated by a special law only if it is necessary for certain administrative areas and if it is in compliance with the GAPA principles. However, since 2016, Article 3 has had an additional provision which aims to strengthen the position of the GAPA as the "basic law" of administrative procedure. According to that provision (which is part of Article $3, \S 2$ ), provisions of special laws must not diminish the level of protection of the parties' rights and legal interests guaranteed by the GAPA. This provision should be taken in conjunction with the provision in Article 214 of the GAPA, which stipulates that all special laws that regulate special issues of administrative procedure differently than the GAPA will be harmonized with the GAPA provisions by June 1st, 2018. The government even established

2 See, for example: D. Milovanović, Vremensko važenje Zakona o opštem upravnom postupku, "Pravni život" 2017, no. 10, pp. 267-281 and P. Dimitrijević, Upravno pravo: opšti deo (peto izdanje), Niš 2019, pp. 235-236.

3 P. Dimitrijević, Upravno pravo..., p. 231. 
a Coordination Body to assess the compliance of special laws with the GAPA provisions (Article 214 (2) GAPA). Nevertheless, its mission has never been fully completed. For example, we can name one Act whose procedural provisions reduce the parties' procedural rights, and that is the Act on Tax Procedure and Tax Administration. ${ }^{4}$ According to that Act, a party's appeal does not delay the enforcement of a decision, even though it is the explicit rule established by the GAPA. However, it is not the sole example of this kind of "deviations". ${ }^{5}$ It is not known when, if ever, the rule contained in Articles 3 and 214 of the GAPA will be fully implemented.

\section{Distinctive institutions and peculiarities of the law on administrative procedures}

This part of Chapter IX provides a detailed analysis of the distinctive characteristics of the Serbian GAPA (2016) in relation to its previous versions and codifications of administrative procedures in other states.

The first distinctive characteristic is that the 2016 GAPA defines the administrative matter. Such a definition was never provided in the previous versions of this Act, although the concept was widely discussed and debated among administrative law scholars. ${ }^{6}$ Comparatively speaking, the practice of defining the concept of administrative matter in GAPAs is not widely accepted, and only several states have taken such an approach (Hungary, among others). ${ }^{7}$ Under the provision of Article 2 of the GAPA 2016, administrative matter is very broadly defined as

an individual situation in which an authority, directly applying the laws, regulations and general acts, legally or factually influences a party's position by issuing administrative acts, guarantee acts, concluding administrative contracts, undertaking administrative actions and providing public services,

but it also entails "any other legal situation designated by law as an administrative matter". As it can be seen, this broad definition of administrative matter includes

4 Zakon o poreskom postupku i poreskoj administraciji (Act on Tax Procedure and Tax Administration), Službeni glasnik RS br. 80/2002, 84/2002-cor., 23/2003-cor., 70/2003, 55/2004, 61/2005, 85/2005-dr.zakon, 62/2006-dr. zakon, 63/2006-dr.zakon, 61/2007, 20/2009, 72/2009dr.zakon, 53/2010, 101/2011, 2/2012-dr.zakon, 93/2012, 47/2013, 108/2013, 68/2014, 105/2014, 91/2015-autentično tumačenje, 112/2015, 15/2016, 108/2016, 30/2018, 95/2018 and 86/2019.

5 For a thorough analysis, see: Z. Lončar, Posebni upravni postupci, "Zbornik radova Pravnog fakulteta u Novom Sadu" 2016, no. 4, pp. 1231-1249.

6 See: S. Lilić, Res Administrativa, Belgrade 2011.

7 Ibidem, p. 92. 
a wide range of almost all administrative activities. This definition ensues half a decade after the definition provided in the Administrative Disputes Act (ADA) 2009. ${ }^{8}$ Due to space limitations, this Chapter will not include the detailed analysis of the legal nature of this definition, and of the differences between those two definitions.

The second peculiarity is considered in relation to the content of the term administrative act. There is a set of states (including Serbia) that narrowly look at the content of the term administrative act, which is understood as an individual administrative, legal act. Typical representatives of this group of countries are Germany, the Czech Republic, the Netherlands, Poland, Sweden, and others. ${ }^{9}$ The Serbian GAPA 2016 classifies administrative acts into two main types; this division did not exist in the previous versions of the GAPA. The first type of administrative act is a decision (rešenje) (including two subtypes), which is used for final regulation of rights, legal interests and obligations of procedural parties, as well as for most important decisions in regard to the ongoing administrative proceedings (e.g. decisions to suspend the proceedings, to dismiss the appeal, to appoint a temporary representative to the party, to retry the proceedings, etc.). The second type of administrative act is called a conclusion (zaključak). It is used in all cases where a decision may not be issued, usually in cases involving oral settlement of procedural issues that can arise in the course of administrative proceedings. The conclusions have the character of an accessory and ancillary act.

A guarantee act and an administrative contract are two other new administrative procedure institutions established by the 2016 GAPA. According to Article 18 of the GAPA, a guarantee act is a written document by which an authority undertakes, at the request of a party, the obligation to issue an administrative act of specific content when specified by a particular legislative act.

Under Article 22 of the GAPA, an administrative contract is a written and bilaterally binding act which can be concluded, when stipulated by a particular legislative act, between a public authority and a party, and which introduces changes or terminates a legal relationship in an administrative matter. Legal provisions regarding administrative contracts are of a general nature, and specific types of administrative contracts can be concluded only when prescribed by the provision of sector laws such as, the Act on Public-Private Partnership and Concessions. ${ }^{10}$

In some of the former versions of the GAPA $(1979,1986)$, the total number of articles contained therein reached 300 articles, which was an expression of the

8 Zakon o upravnom sporu (Administrative Disputes Act), Službeni glasnik RS br.11/2009. Within the meaning of this Act, "Administrative matter... is an undisputed individual situation of public interest in which the need arises, directly from legal regulations, to determine the party's future conduct authoritatively and legally".

9 J.-B. Auby, General Report, [in:] Codification of Administrative Procedure, ed. J.-B. Auby, Bruxelles 2014, p. 8.

10 Zakon o javno-privatnom partnerstvu i koncesijama (Act on Public-Private Partnership and Concessions), Službeni glasnik RS br. 88/2011, 15/2016 i 104/2016. 
tendency to over-regulate, over-codify and make it as similar as possible to the Civil Procedure Code. The new 2016 GAPA contains a total of 217 articles, divided into ten parts: 1) introductory provisions and basic principles; 2) administrative action; $3)$ general rules of procedure; 4) first instance procedure; 5) decision and conclusion; 6) legal remedies; 7) exceptional cases for repealing and modifying a decision; 8) enforcement procedure; 9) penalties; and 10) transitional and final provisions.

Like Polish, Croatian, and many other administrative procedures codifications, the Serbian 2016 GAPA contains many legal principles (eleven to be exact). The GAPA explicitly states the following principles of administrative procedure: the principle of legality and predictability; the principle of proportionality; the principle of protection of the rights of the parties and the exercise of public interest; the principle of assistance to a party; the principle of the efficiency and effectiveness of the proceedings; the principle of truth and the free assessment of evidence; the parties' right to submit pleadings; the principle of independence; the right of appeal and objection; the principle of the validity of the decision; and the principle of access to information and data protection. The principles of predictability, proportionality, the right to objection (as a new legal remedy), and free access to information and data protection have been explicitly envisaged in the 2016 GAPA for the first time.

As for the basic rules of procedure (Part III of the GAPA), significant changes can be found in Chapters regarding: participants in administrative proceedings (Articles 33-55); communication between public authorities and parties (Articles 56-65); and costs of the proceedings (Articles 84-89). The author will point to the most important ones.

Acting officials are now more precisely defined, and they must be named in the heading of the administrative decision. Reasons for their exemption (Article 40 GAPA), apart from those provided in relevant laws defining the conflict of interest and anti-corruption measures, have been broadened, and the procedure for exemption of acting official is now very precise. The Point of Single Administrative Contact is a completely new institution which will be explained in detail below.

When the parties to administrative proceedings are concerned, the GAPA envisages two completely new categories, in addition to the common ones. Representatives of collective interests (various non-governmental organizations, citizens' associations - e.g. fishermen's associations, military pensioners' associations, consumer protection associations, etc.) and representatives of the general public (e.g. the Red Cross, the Children's Rights Center, the Ecological Center), organized in accordance with the relevant laws, can have the status of a party to administrative proceedings if the outcome of the administrative proceedings may affect the interests that they represent (Article 44 GAPA).

Costs of the proceedings are elaborated in more details, and some new rules are envisaged. According to Article 84 of the GAPA, those costs include expenditure on 
fees, personal expenses of the party (expenses of coming to a hearing and loss of time and earnings), the necessary and justified costs of representing the party, and the costs of the oral hearing and presentation of evidence (actual costs of witnesses and actual costs and rewards of expert witnesses, interpreters, translators, temporary representatives, and inspection costs), and special expenses of the authority conducting the procedure (e.g. officials' travel expenses paid in cash). If, during the second instance proceedings, the appeal is denied or rejected, or the appellant withdraws the appeal, the costs of the second-instance procedure will be paid by the appellant! The costs of the proceedings are awarded within the main decision on the administrative matter, unlike the previously existing possibility to decide about costs in a separate conclusion. Those costs may include award that can be given to experts, interpreters, translators and temporary representatives.

When it comes to initiating the procedure, the exact moment when the procedure is considered initiated is now precisely prescribed and connected to the moment when the authority has received the party's request (if the proceeding is initiated by the party). This is considered very important because of the right to a fair trial time limits in decision-making processes_established by the European Court of Human Rights. In order to tackle this issue, Serbia has even enacted the special Act on the Protection of the Right to Trial within a Reasonable Time. ${ }^{11}$ If the proceeding is initiated by a public authority, the exact moment is specified as follows:

1. When the authority takes any action to conduct the proceedings (in the interest of the party).

2. When the party is notified about the act of initiating the proceedings (if the initiation of proceedings is not in the interest of the party).

The position of a person who does not participate in the proceedings as a party is additionally strengthened. Until the completion of the second instance proceedings, this person may apply to acting authority to be recognized as a party. Failure to act in accordance with that rule is the reason for reopening of the administrative proceedings, according to which the procedure will be repeated if terminated by a decision against which there is no ordinary legal remedy, and "if the person who could have been a party to the proceedings was not given an opportunity to participate in the proceedings" (Article 176 GAPA). Also, the authority is obliged to issue a notice of a decision made to a person who is not recognized as a party (Article 152 GAPA). This is also a new and significantly improved part of the GAPA.

We have already pointed out that the GAPA has introduced a new legal remedy, in addition to appeal, which is designated as the objection (prigovor). The objection is regulated in Articles 147-150 of the GAPA. It is a legal instrument that can be used for the assessment of the legality and expediency of all types of administrative actions, except for an administrative act and a guarantee act (which are subject

11 Zakon o zaštiti prava na suđenje u razumnom roku (Act on the Protection of the Right to Trial within a Reasonable Time), Službeni glasnik RS br. 40/2015. 
to filing an appeal). So, the objection can be used in all administrative matters which do not have the character of an administrative act, nor are they related to the adoption of an administrative act, and when the complainant considers that his/her rights or legal interests have been violated in those administrative action cases. The notion of an administrative action in the context of objection includes administrative contracts, administrative activities (especially issuance of certificates), and the provision of public services. The objection is allowed only if no other legal remedy can be claimed in administrative proceedings (Article 147(1) GAPA); it is a remonstrative remedy which is filed with the head of the same administrative authority or organization which has taken the administrative action (Article 148 GAPA).

The rules related to appeal have also been improved (by specifying the legal grounds for appeal, the time limit of one year for filing an appeal on administrative inertia or silence of the administration, the obligatory response to appeal by the first instance authority). This also applies to extraordinary legal remedies which have been redefined and merged; moreover, Article 185 of the GAPA introduces a new remedy: annulment, revocation or amendment of the final decision on the recommendation of the Ombudsman. Due to space limitations, these remedies will not be explored in more detail.

\section{The relation between legal institutions on administrative procedures and the judicial review model}

One of the peculiarities of Serbian administrative law (in a broader sense) is that the administrative dispute control of administrative actions had been established much before the enactment of the first GAPA in the times of former Yugoslavia. The first competences in this area were adopted and put into force in 1869, when the Serbian State Council (as part of the executive branch of the Government of the Principality of Serbia) was given the power to review and decide on appeals against ministerial decisions in disputed administrative matters. The Principality of Serbia used the French Council d'Etat as the role model for its system of resolving administrative disputes. ${ }^{12}$ The final resolution of administrative disputes remained in the hands of

12 President of the Administrative Court, Judge Mrs. J. Ivanović noted: "Thus, in addition to France which laid the foundations of the administrative judiciary as early as in 1799, establishing the Council of State as the administrative court, Serbia became one of the first European states to provide protection to its citizens through the administrative dispute". 
the State Council until World War II. In the period between the First and the Second World War, administrative courts were established as first instance courts in charge of judicial review of administrative acts while the State Council became second instance authority in charge of deciding on certain types of administrative disputes. After World War II, administrative dispute resolution was reestablished in 1952, but within the system of regular and supreme court(s). This was the case until 2010 when the Administrative Court was established, under the Court Organization Act, ${ }^{13}$ as a single instance court of exclusive jurisdiction. The rules for adjudicating administrative disputes in the Administrative Court were established in the Administrative Disputes Act 2009. ${ }^{14}$ Decisions of the Administrative Court cannot be appealed but they may be challenged by claiming extraordinary legal remedies. The most important form of the decision is the cassation judgment of the Administrative Court, which annuls the effects of the disputed second-instance decisions of administrative authorities. The Administrative Court has jurisdiction to decide in cases involving administrative silence; it can also issue declaratory judgments and make the court-ordered adjournment of the enforcement of an administrative act. ${ }^{15}$

As for the scope of activities of the Administrative Court, Judge J. Ivanović noted:

The Administrative Court has about 100 grounds for dispute and implements more than 300 substantive laws and many bylaws. In addition, the complexity of cases varies - from the less complex ones in terms of facts or legal issues, to extremely complex cases, such as competition, revocation of banking licenses and licenses of insurance companies, public procurement, broadcasting, restitution and indemnification, and other issues that require an extremely long preparation for trial, which can sometimes take several months, and most frequently the holding of a public oral hearing. ${ }^{16}$

All these activities can hardly be performed on time by a single court. For this reason, the state has decided to establish two-tier administrative judiciary, as stated in the National Judicial Reform Strategy for the period 2019-2024, whose draft

J. Ivanović, Foreword, [in:] Zbornik radova 150 godina upravnog spora u Srbiji 1869-2019/The Collection of Papers 150th Anniversary of the Administrative Dispute in Serbia 1869-2019 (bilingual edition), ed. V. Cucić, Belgrade 2019, p. 14 (joint publication of the Administrative Court and the Faculty of Law in Belgrade, http://www.up.sud.rs/uploads/useruploads/Documents/ Zbornik-radova-150-godina-upravnog-spora-1869-2019.pdf, accessed: 11.01.2020).

13 Zakon o uređenju sudova (The Court Organization Act), Službeni glasnik RS br. 116/2008, 104/2009, 101/2010, 31/2011-dr. zakon, 78/2011-dr. zakon, 101/2011, 101/2013, 106/2015 i 40/2015-dr. zakon).

14 Zakon o upravnim sporovima (Administrative Disputes Act), Službeni glasnik RS br. 111/09.

15 D. Vučetić, Types of Decisions in the Administrative Dispute Procedure, [in:] Zbornik radova 150 godina..., p. 219.

16 J. Ivanović, The Historical Development of the Administrative Judiciary of Serbia, [in:] Zbornik radova 150 godina..., pp. $72-73$. 
was prepared by the Ministry of Justice of the Republic of Serbia in $2019 .{ }^{17}$ In consequence, this will require changes of the GAPA, especially in the domain of the appellate procedure. One of the specificities of Serbian administrative law is that the administrative procedure was always reformed after the reform of the administrative judiciary and not vice versa (as would logically be the case).

\section{Influence of the Austrian codification idea on the form of contemporary legal solutions}

The Austrian administrative procedure law codification has had, despite all other contemporary influences from civil law, comparative law, and European law, a strong influence on the groundwork of Serbian administrative procedure (which predates the times of former Yugoslavia). One can even say that all those contemporary influences have been mostly additions to the foundations based on the Austrian model. These foundations comprise: the individual administrative act as a result of the administrative procedure; the principles of administrative action; the parties' right to be heard; ensuring impartiality by exemption of the acting public official; giving due consideration to any documents produced by parties; ensuring participation of the interested party as an essential condition for full effectiveness of the administrative act; the procedure for establishing the facts, presenting documents and evidence; the party's right to be heard before a decision is taken; the right to know the reasons for the decision; the right to appeal against the decision, the right to reopen the procedure, etc. ${ }^{18}$ All these institutions provided a solid ground for the protection of individuals in administrative proceedings initiated by the state in times when the state pervaded all areas of social life. It also has to be noted that even the first version of Yugoslav GAPA, although based on the Austrian model, was almost twice the size of the Austrian one (it contained 176 articles). The main reason for such an increase in the number of articles is the incorporation of institutions of civil procedure into Yugoslav general administrative procedure rules. ${ }^{19}$ In the author's opinion, all these procedural institutions were the precursors of what is today known as the principle of good administration, which will be further explained in the next point.

17 See the official webpage of the Serbian Ministry of Justice: https://www.mpravde.gov.rs/ sekcija/703/reforma.php (accessed: 11.01.2020).

18 A.F. Zumbini, Judicial Review of Administrative Action in the Austro-Hungarian Empire: The Formative Years (1890-1910), "Italian J.Pub. L.” 2018, no. 10, pp. 46-48.

19 D. Milkov, Upravno pravo - knjiga II (Administrative law - book II), Novi Sad 2017, p. 80. 


\section{The impact of the European law on national legislature and judicature}

In general, there are two distinctive public administration doctrines that had a substantial influence on public administration regulations (particularly substantive legislation), including Serbian regulations in this matter. The first one is the New Public Management (NPM) Theory, which entails the notion of efficiency and effectiveness of administrative proceedings, optimization, simplification and digitalization of administrative procedure. The second, more recent and broader doctrine is the doctrine of Good Governance, which focuses on openness, transparency and participation of citizens in administrative proceedings. Those doctrines are embodied in many of the European legislative provisions and judicial decisions (case law). ${ }^{20}$

Given the fact that Serbia currently has the status of a candidate country for joining the European Union, its administrative capacities are assessed periodically. The SIGMA (Support for Improvement in Governance and Management), a joint initiative of the EU and OECD, had a strong impact on the new Serbian GAPA 2016. Based on the questionnaire developed within that organization, the SIGMA's draft version of GAPA was proposed. Besides the EU legislation (the Charter of Fundamental Rights of the European Union 2000), the Council of Europe and a series of its Recommendations ${ }^{21}$ had a strong influence on the final version of the adopted GAPA. However, the EU legislative document that had the most substantial impact on the current version of the GAPA is Directive 2006/123/EC of the European Parliament and of the Council of 12 December 2006 on services in the internal market. ${ }^{22}$ All provisions of the new GAPA promoting the simplification of administrative proceedings, creation of points of single administrative contacts, e-administrative proceedings, a different concept of the idea of the silence of administration (presumptions for accepting the party's request [in some cases]) are prescribed under the direct influence of this Directive. The situation was similar in other countries of the region.

20 D. Đerđa, Towards the Codification of EU Administrative Procedural Law, [in:] EU Administrative Law and its Impact on the Process of Public Administration Reform and Integration into the European Administrative Space of South East European Countries, Skopje 2014, pp. 79-83 and D. Vučetić, Codification of European administrative procedure law and its reflections on Serbian public administration reform, [in:] ibidem, pp. 99-107.

21 A. Pavlovska-Daneva, Contemporary and Future Perspectives of Administrative Procedure in the EU, [in:] EU Administrative Law..., p. 87.

22 Directive 2006/123/EC of the European Parliament and of the Council of 12 December 2006 on services in the internal market, Official Journal L 376, 27 December 2006, pp. 0036-0068. 


\section{Openness to innovation: Is the goal of modernization visible in the activities of the legislature?}

This question has been addressed in more detail in a recently written paper that is currently in print. ${ }^{23}$ The paper focuses on the process of digitalization, analyzing the specific GAPA provisions that enable and promote ICT usage during administrative decision making.

The crucial provisions that have contributed to the modernization of Serbian administrative procedure can be found in Articles 9, 102, and 103 of the Serbian GAPA 2016. Article 9 GAPA envisages a general principle of efficiency and effectiveness (procedural economy), which is subsequently developed in Articles 102 and 103 of the GAPA, and a series of Government decrees and regulations. All those regulations, together with the E-Government Act 2018, have led to the creation of the system for electronic communication of all public authorities, which is used in decision-making processes in different administrative procedures. This system (previously called e-GAPA) has freed citizens and entrepreneurs from unnecessary compiling of data for administrative decision making of public authorities, particularly of this data that is already available in the registries of the public authorities. The first effects of implementing ICT in administrative procedures are more than encouraging. Eight key central government authorities exchange their data kept in online registries. By winter 2019, according to the official data of the Ministry of State Administration and Local Self-Government, public servants officially exchanged information more than 4 million times, without asking the citizens to produce them, which was the case in previous years. ${ }^{24}$

Other improvements include the introduction of necessary prerequisites for implementing the Points of Single Administrative Contacts (PSAC) under Chapter III of the GAPA entitled Basic Rules of Procedure and its section 3 Cooperation and Official Assistance. Specifically, Article 42 GAPA provides the basis for the implementation of the PSAC, and there are some very successful examples of its implementation both at the national and local levels. Under the 2016 GAPA, e-communications between parties and authorities and hard-copy forms of communication have been given an equal legal footing and effects. Provisions on e-notification (as a particular type of official communication) have been developed and

23 See: D. Vučetić, Zakon o opštem upravnom postupku i informaciono-tehnološko unapređenje rada srpske uprave, [in:] Collection of Summaries/International Scientific Conference "Law and Multidisciplinarity", Niš 2019, p. 15.

24 According to the data provided by the Ministry of Public Administration and Local Self-Government, http://mduls.gov.rs/reforma-javne-uprave-u-srbiji/modernizacija-administracije/ informacioni-sistem-ezup/?script=lat (accessed: 11.01.2020). 
made more precise. They are increasingly being used in practice in combination with the relevant parts of the Electronic Government Act 2018, ${ }^{25}$ the Electronic Document Act 2009, ${ }^{26}$ and the Electronic Document, Electronic Identification and Trust Services in Electronic Commerce Act 2017. ${ }^{27}$ Another significant ICT improvement in the GAPA entails the possibility of using videoconference tools for oral hearings, if the authority and parties have adequate technical capacities (Article 111 GAPA), and making decisions in electronic form.

\section{Codification of administrative procedure and decodifying trends}

This question is closely connected to the issues elaborated in point 2 of this Chapter. Decodifying trends are closely connected to the degree to which special laws that regulate so-called special administrative procedures deviate from the procedural guarantees of citizens right's envisaged in the GAPA. Unfortunately, due to the inadequate mechanisms provided in the GAPA (instructional deadline for harmonization of special laws) and no legal sanctions for non-harmonization, the goal of full harmonization of special administrative procedure rules with the GAPA can hardly be achieved soon. A much better solution was proposed by Lončar, who noted that the GAPA should prescribe the mandatory prior approval of the competent ministry in charge of public administration in every case of drafting special laws which include provisions on special administrative procedures. ${ }^{28}$ This would preclude that lex specialis from entering the legislative procedure if it is not fully aligned with the GAPA. Good example is the case of the Netherlands, where the "introduction" of GAPA "triggered a huge operation to amend other legislation", in order "to bring it in line with the provisions of the GALA", which comprised thousands of amendments spread across hundreds of statutes. The Dutch kind of so-called "cultural revolution in the field of administrative law" 29 is most likely to remain an unfulfilled dream for the Serbian counterpart.

25 Zakon o elektronskoj upravi (Electronic Government Act), Službeni glasnik RS br. 27/2018.

26 Zakon o elektronskom dokumentu (Electronic Document Act), Službeni glasnik RS br. 51/2009.

27 Zakon o elektronskom dokumentu, elektronskoj identifikaciji i uslugama od poverenja u elektronskom poslovanju (Electronic Document, Electronic Identification and Trust Services in Electronic Commerce), Službeni glasnik RS br. 94/2017.

28 Z. Lončar, Posebni upravni..., p. 1247.

29 T. Barkhuysen, W. Den Oüden, Y.E. Schuurmans, Netherlands, [in:] Codification..., p. 267. 


\section{Codification of administrative procedure and practice}

Although it may be too early to assess the application of the Serbian GAPA 2016 in practice, one can tell that the main challenge is most likely to be the implementation of the principle of legitimate expectations in the everyday practice of numerous authorities that apply the GAPA. This especially applies to the units of local self-government, which apply approximately 200 different special administrative procedures at the local level. This can potentially put the parties in an unequal legal position, based on the fact that they live in different local units. In order to prevent this possibility, the Ministry of Public Administration and Local Self-Government (MoPALSG) together with the national association of local government units called Standing Conference of Towns and Municipalities (SCTM) has taken necessary measures aimed at standardizing administrative procedures at the local level by establishing unified registries of special administrative procedures, which have been made available to the interested parties through e-registries posted on the official LSG web-sites. This action will significantly reduce the administrative discretion of the acting officials. Legal certainty and legitimate expectations can further be improved by ensuring increased transparency and publication of administrative inspection reports which enable control over the application of the GAPA in the practice of numerous administrative authorities.

\section{Successes and failures: What has not been achieved?}

The enactment of the 2016 GAPA was aimed at accomplishing the following goals: to shorten the general administrative procedure; to extend the GAPA protection of the parties to the provision of public services; to regulate the basics of administrative contracts; to regulate the exercise of administrative actions; and to protect the parties' rights in broad areas governed by special administrative procedures. The new GAPA distanced itself from an almost 90-year old type of administrative process based on the Austrian administrative tradition, which was under the scrutiny of the scholarly public. ${ }^{30}$ Despite those controversies, the new GAPA contains several significant improvements, such as: the definition of administrative matter; some

30 V. Cucić, Fino podešavanje Zakona o opštem upravnom postupku, "Anali Pravnog fakulteta u Beogradu" 2018, vol. 66, issue 2, p. 140. 
new principles, such as predictability and proportionality; two new categories of parties; defined moment of initiating the proceedings; a strengthened position of persons who do not participate in the proceedings as parties; and objection as a new legal remedy.

In the author's opinion, the most significant accomplishment of the 2016 GAPA (which exceeds legal effects sensu stricto) is the full implementation of digitalization in every possible area of administrative decision making. As already explained in point 7 of this Chapter, it has enhanced the efficiency and effectiveness of administrative proceedings to a completely new level and significantly reduced the costs for citizens and even more for entrepreneurs.

However, at the same time, this fact shows that the government has indirectly given up the initial idea of enacting the GAPA as the "supreme" law in the area of administrative proceedings. In consequence, this fact has permanently diminished the legal position of the parties in numerous special administrative procedures, which will remain unchanged and un-harmonized with the GAPA standards.

\section{General conclusions and comments on the prospects for the development of the law on administrative procedure}

In author's opinion, the 2016 GAPA has struck a good balance between the demands of the EU regulations, the adaptation to the Good Governance doctrine, and the successful implementation of the ICT solutions into the administrative decision making. At the same time, Serbian lawmakers had to preserve the essential characteristics of the Yugoslav and Austrian tradition of administrative procedure law, which prevailed for almost a century. Generally speaking, it can be concluded that GAPA 2016 is a piece of legislation that only needs to be further clarified both to citizens in pursuit of exercising their rights and to public officials in charge of resolving disputes and deciding on parties' obligations. Apart from the troublesome relationship (thoroughly analyzed above) between the GAPA and special administrative procedure laws and regulations which has to be resolved, there is a series of bylaws that have to be adopted in order for the GAPA to be fully implemented. In many areas, the GAPA is only an indirect source of administrative procedural law. It cannot be implemented without enacting new or amending numerous existing laws that regulate different areas of social life. This especially refers to the new institutions, such as administrative contracts and guarantee acts, which have been explained in point 3 of this Chapter.

Another opportunity that is to be considered in the future is to implement mediation and other forms of alternative dispute resolution (ADR) methods in case 
of multiparty administrative procedure that can be terminated by settlement. ${ }^{31}$ Settlement is regulated by Article 99 of the GAPA, in order to simplify and avoid unnecessary costs of administrative procedure. According to the GAPA, throughout the proceedings, an authorized official shall pursue either full or partial settlement when the (private) parties involved in the proceedings raise contentious claims. Settlement cannot be conducted between the parties and a public authority, and the subject matter of settlement can only be the rights or interests at the parties' disposal. In other words, it cannot be used in administrative matters involving a public interest. According to the judgment of the Supreme Court of Serbia from 2005,

Settlement is a contract between the parties and in settlement proceedings it is not possible to file a request for reopening of proceedings but, under certain conditions, a party may file a request to cancel the settlement in court proceedings. ${ }^{32}$

For that reason, regular administrative proceeding legal remedies cannot be used against it. Like any other settlement, this kind of settlement (although rare in administrative law) is suitable for modern types of termination of administrative procedure, such as mediation.

Finally, the 2016 GAPA is most likely to be changed soon, especially in the context of the announced changes to the administrative disputes resolution system. It would be the perfect time for some additional fine-tuning of the GAPA text which has already been precisely identified in Serbian administrative law literature. ${ }^{33}$

\section{Serbia}

Obowiązujące obecnie w Serbii zasady postępowania administracyjnego zostały po raz pierwszy formalnie skodyfikowane w Królestwie Jugosławii. Po rozwiązaniu federacji jugosłowiańskiej pod koniec XX w., w Serbii stosowano - co do zasady - ustawę jugosłowiańską z pewnymi modyfikacjami. Trwało to do 2016 r., kiedy to uchwalono nową ustawę o ogólnym postępowaniu administracyjnym (the General Administrative Procedure Act - GAPA).

Zgodnie z art. 1 serbskiej ustawy z 2016 r., podmiotami zobowiązanymi do jej stosowania są państwowe organy i organizacje, władze i organizacje autonomii prowincjonalnej, władze i organizacje samorządów lokalnych, instytucje, przedsiębiorstwa publiczne, specjalne organy pełniące funkcje regulacyjne oraz osoby

31 On the possibility of using mediation in administrative proceedings in Serbia, see: D. Vučetić, Is Mediation viable in Administrative Matters?, [in:] Facta universitatis: Series Law and Politics (vol. 14, no. 4). Niš 2016, pp. 495-504.

32 Decision of the Supreme Court of Serbia, U. 2799/2004 of 13.01.2005.

33 V. Cucić, Fino podešavanje Zakona..., pp. 158-159. 
prawne i fizyczne, którym powierzono na zasadzie delegacji wykonywanie uprawnień publicznych. W kolejnych częściach GAPA wszystkie te podmioty zostały określone ogólnie jako „władze”.

Charakterystycznymi cechami serbskiej ustawy o ogólnym postępowaniu administracyjnym są, poza wyliczeniem i określeniem składników treści zasad tego postępowania, wyczerpujące zdefiniowanie m.in. pojęć sprawy administracyjnej, aktu administracyjnego, przyrzeczenia administracyjnego, umowy administracyjnej czy „jednego punktu kontaktu z administracją”. Nowa ustawa wyraźnie wzmocniła pozycję strony oraz osoby, której wniosek o przyznanie statusu strony postępowania został odrzucony. Przepisy GAPA wskazały również dokładny moment, w którym postępowanie uznaje się za wszczęte (zarówno na wniosek strony, jak i z urzędu), wprowadziły nowy środek zaskarżenia w postaci sprzeciwu oraz uzupełniły wcześniejsze uregulowania w odniesieniu do odwołania i nadzwyczajnych środków zaskarżenia decyzji.

W ocenie Autora, mimo dostrzeganego współcześnie wpływu prawa cywilnego, prawa europejskiego i doktryny dobrego zarządzania na kształt analizowanych unormowań proceduralnych, w serbskim GAPA nadal widoczna jest spuścizna austriackiej kodyfikacji postępowania administracyjnego. Wspomniane dziedzictwo obejmuje takie elementy, jak konstrukcja indywidualnego aktu administracyjnego traktowanego jako forma zakończenia postępowania, zasady działania administracji, gwarancje bezstronności orzekania (wyłączenie urzędnika od udziału w postępowaniu), uwzględnianie wszelkich dokumentów przedstawianych przez strony i udział w postępowaniu zainteresowanych stron jako niezbędny warunek pełnej skuteczności aktu administracyjnego, tryb ustalania faktów i gromadzenia dowodów, prawo stron do wysłuchania przed podjęciem rozstrzygnięcia i do zapoznania się z uzasadnieniem decyzji czy wreszcie prawo do odwołania się od decyzji i żądania wznowienia postępowania. Pierwsza jugosłowiańska kodyfikacja postępowania administracyjnego była - jak podkreśla Autor - dwukrotnie obszerniejsza od swojego austriackiego pierwowzoru (liczyła aż 176 artykułów).

W kontekście modernizacji serbskiej procedury administracyjnej szczególną uwagę zwraca się na współczesne trendy w rozwoju komunikacji elektronicznej. Znalazły one odzwierciedlenie w postanowieniach GAPA dotyczących cyfryzacji postępowania, która niewątpliwie sprzyja realizacji zasad ekonomiki procesowej i oszczędności kosztów. Najważniejsze przepisy, które przyczyniły się do unowocześnienia serbskiej procedury administracyjnej można znaleźć w art. 9, 102 i 103 GAPA. Wraz z ustawą o e-administracji z 2018 r. oraz szeregiem dekretów i rozporządzeń rządowych stworzyły one spójny system komunikacji elektronicznej, wykorzystywany przez większości organów publicznych w różnych trybach postępowania administracyjnego. Znacznie ułatwiło to załatwianie spraw urzędowych przez obywateli i przedsiębiorców.

Omawiając model sądowej kontroli aktów administracyjnych, Autor wskazuje, że jedną z osobliwości serbskiego prawa administracyjnego jest ukształtowanie tej 
instytucji już w 1869 r. w czasie istnienia Księstwa Serbii. Utworzono wówczas serbską Radę Stanu (wykorzystując za wzór francuską Conseil d'Etat) jako organ powołany do rozpatrywanie odwołań od decyzji ministerialnych w spornych sprawach administracyjnych. Między pierwszą i drugą wojną światową powołano sąd administracyjny jako sąd pierwszej instancji - funkcjonujący obok Rady Stanu. Po drugiej wojnie światowej rozstrzyganie sporów administracyjnych na drodze sądowej zostało zniesione. Ten tryb reaktywowano w 1952 r., ale jedynie na poziomie sądów najwyższych. W 2010 r. ustanowiono w Serbii Sąd Administracyjny jako sąd jednoinstancyjny o wyłącznej jurysdykcji. Najważniejszą formą orzekania przez ów sąd jest wyrok kasacyjny, który eliminuje skutki spornych decyzji organów administracyjnych drugiej instancji. W sferze kompetencji Sądu Administracyjnego leży również orzekanie w sprawach dotyczących milczenia administracji, wydawanie orzeczeń o charakterze deklaratoryjnym oraz zarządzanie wstrzymania wykonania aktów administracyjnych.

Autor opisuje relacje między GAPA a wieloma ustawami szczególnymi, z których niektóre zawierają unormowania wyłączające stosowanie przepisów o ogólnym postępowaniu administracyjnym. Zauważa on, że istnieją znaczne odstępstwa od zasad GAPA, które prawdopodobnie będą jeszcze długo obowiązywać. Z tego powodu rząd Serbii, Ministerstwo Administracji Publicznej i Samorządu Lokalnego oraz krajowe stowarzyszenie jednostek samorządu terytorialnego o nazwie Stała Konferencja Miast i Gmin podjęły niezbędne środki w celu unifikacji postępowania administracyjnego zarówno na poziomie lokalnym, jak i krajowym przez ustanowienie jednolitych rejestrów szczególnych trybów postępowania administracyjnego. Ma to przyczynić się do ograniczenia marginesu swobody działania urzędników.

Autor eksponuje także fakt, że GAPA jest - w niektórych dziedzinach administracji - pośrednim źródłem prawa o postępowaniu administracyjnym, którego nie da się stosować bez wydania przepisów szczególnych i aktów wykonawczych do ustawy. W jego ocenie, pożądane byłoby włączenie do regulacji GAPA przepisów o mediacji w postępowaniu w sprawach $\mathrm{z}$ udziałem więcej niż jednej strony, które z powodzeniem można by zakończyć w formie ugody.

(tłum. Monika Kmieciak)

Dejan Vučetić, LL.D., Associate Professor at the Faculty of Law, University in Niš, Serbia. He teaches the following courses: Administrative Law, Public Administration, Legal Informatics, Special Administrative Law, Local Self-Government Law, Media Law, and Police Law. Since February 2017, he has been teaching the Administrative Law course at the Department of Social Policy and Work, the Faculty of Philosophy, University of Niš. Prof. Vučetić has abundant eighteen-year experience of participating in the realization of various projects in areas of public 
administration and local self-government. As an expert, he has cooperated with the Council of Europe (as an expert consultant on the project of introducing a human resource management system into twenty selected local self-government units in Serbia), the Standing Conference of Towns and Municipalities of Serbia and the Ministry of State Administration and Local Self-Government, the Office of the National Council for Decentralization established by the Government of the Republic of Serbia, etc. 


\title{
Chapter X \\ Slovak Republic
}

\author{
Juraj Vačok, Ph.D., Associate Professor \\ Comenius University in Bratislava \\ Faculty of Law, Department of Administrative Law and Environmental Law \\ juraj.vacok@flaw.uniba.sk
}

iD https://orcid.org/0000-0002-7490-6564

\section{The stages of the evolution of the law on administrative proceedings - from the first codification}

During the Austro-Hungarian Monarchy times, the Slovak lands belonged to the Kingdom of Hungary. After the First World War, the territory of the current Slovak Republic became a part of the Czechoslovak Republic. This republic was established on 28 October $1918 .^{1}$ From the beginning of the Czechoslovak Republic, the legal regulation of the Austria-Hungarian Monarchy was still in force. This was established on the basis of Article 2 of Law no. 11/1918 Collection of Laws (hereafter: Coll.) on establishment of separate State of Czechoslovakia. This Article stipulated that all existing country laws and empire laws remained in force. The first codification of administrative proceedings was adopted in 1928. It was the Regulation of the Government of the Czechoslovak Republic no. 8/1928 Coll. on proceedings in matters falling within competence of political authorities (administrative proceedings). Since Slovak Republic and Czech Republic remained one country for a long time, the legal history of those two countries is common to large extent. It is therefore described in chapter $\mathrm{V}$, regarding the Czech Republic law and not repeated again here.

1 See details K. Malý and others, Dějiny českého a slovenského práva do r. 1945, Praha 2010, pp. 313-334. 
The different development was during the Second World War when was established the Slovak State ${ }^{2}$ in most of the territory of the contemporary Slovak Republic. During the existence of this state was still in force the Regulation of the Government of the Czechoslovak Republic no 8/1928 Coll. on proceedings in matters falling within the competence of political authorities (administrative proceedings). This law was in force in this territory also after the restoration of the Czechoslovak Republic. It was replaced by the Regulation of the Government of the Czechoslovak Republic no 20/1955 Coll. on proceedings in administrative matters (Administrative Code).

Now, the common Law no 71/1967 Coll. on administrative proceedings - Administrative Procedural Code (zakon o správnom konani or správny poriadok), which was adopted for the whole Czechoslovak Socialistic Republic, is still in force in the Slovak Republic. It was amended 10 times, but most of the amendments were not significant. The structure, main principles and most of the provisions are retained.

\section{The scope of the code on administrative proceedings}

The scope of the Administrative Procedural Code is established in its Section 1 $\$ 1$. Pursuant to this provision, this law regulates the proceedings, in which the administrative authorities in the area of the public administration decide about the rights, interests protected by the laws and obligations of the private persons and legal entities. This does not apply when the particular laws provide something different. ${ }^{3}$

This scope of the Code is very general and involves large number cases and it is difficult to mention all of them. The reason of is that this Act regulates all legal relations which fulfil the characteristics stipulated in its Section $1 \S 1$. The extent of the legal regulation can be changed by special laws, which may exclude the application of the

2 The Slovak State was established on the 14 March 1939. On the 21 July 1939 it was renamed to the Slovak Republic. This state continued until the 8 May 1945 when was renewed the Czechoslovak Republic (See closer D. Škvarna et al., Lexikón slovenských dejín, Bratislava 1997, pp. 301-302).

3 The text of this provision in Slovak language is: Tento zákon sa vztahuje na konanie, $v$ ktorom v oblasti verejnej správy správne orgány rozhodujú o právach, právom chránených záujmoch alebo povinnostiach fyzických osôb a právnických osôb, ak osobitný zákon neustanovuje inak. 
Code ${ }^{4}$ or can regulate some legal institutions differently. ${ }^{5}$ Because of that, it is possible to state, that the relationship between the special laws and the Code is built on the principle of subsidiarity. According to this principle, lex specialis derogat legi generali.

In compliance with the abovementioned principle, the legal theory distinguishes three kinds of relations of the Code and the separate provisions. The first is when the application of the Code is excluded, the second is when the Code modifies the situation created by special laws. The third is when the Code regulates the whole administrative proceedings. ${ }^{6}$

\section{Characteristic institutions and peculiarities of law on administrative proceedings}

Administrative Procedural Code is based on the conception of the previous legal acts mentioned in chapter $\mathrm{V}$ of this book, including the principle of two-instance proceedings. It is also possible to state that this law is built in favor of the participants of the proceedings. That means that the participants have more procedural rights in comparison with obligations and that the administrative authority takes the whole responsibility for the procedure and its outcome. The law consists of six parts. The First one is called Introductory Provisions, the Second part - Administrative Authorities, Participants of the Proceedings and Concerned Persons, the Third part - Procedure, the Fourth part - Review of Decisions, the Fifth part - Enforcement of a Decision, and the Sixth part - Transitional and Final Provisions.

The First part regulates the scope of the Code and the main principles, which are the principle of legality, the participation principle, the principle of speed proceedings, the principle of economy procedure, the principle of material objectivity, the principle of material equality in decision-making, the access to public information principle, the cooperation principle and the principle of procedural equity. ${ }^{7}$

4 For instance, pursuant to Section 163 of Law no. 563/2009 Coll. on the administration of taxes (Tax Procedural Code) on the amendment of certain laws as amended the Administrative Procedural Code does not apply to the tax proceedings.

5 For instance, Section 72 of the Law no. 372/1990 Coll. on the minor offenses as amended (hereinafter referred to as Minor Offences Code) establishes the participants of the proceedings in minor offenses (priestupok) matters differently from the regulation established in Administrative Procedural Code.

6 See in details S. Košičiarová, Správne právo procesné. Všeobecná čast', Šamorín 2015, pp. 114-115.

7 See in details M. Vrabko et al., Správne právo procesné. Všeobecná čast', Bratislava 2013, pp. 61-69. 
The Second part regulates the main subjects of the proceedings which are administrative authorities, participants of the proceedings and other concerned persons. There are also the provisions which provide the administrative authorities with competence, which is divided into substantive, territorial and functional. This part also regulates the bias of the members of administrative authorities and the representation of the participants of the proceedings. It should be explained, that unlike the employees of the authorities, the holders of the functions cannot be disqualified. ${ }^{8}$

The determining of the participants belongs to the administrative authority. Pursuant to Section $14 \$ 1$ of the Code the participants of the proceedings are also persons who claim that their rights and obligation could be interfered with the decisions until the contrary is proved by administrative authorities, which causes many problems in praxis. ${ }^{9}$

The Third part regulates the first instance administrative proceedings and remedies. It could be marked as the main part of the Code, which includes the initiating of the proceedings, collecting evidence, the measures to ensure the procedure and the aim of the proceedings and the decision. The procedures can start from the initiative of the private persons when they seek to decide about their subjective rights or from the initiative of the administrative authorities in matters of public interest. The applications of the private entities are considered according to their contents. The administrative authorities shall consider which rights should be the subject-matter of the procedures. The right for filling applications is not limited. This causes many problems in praxis because the administrative authorities are often overloaded. The beginning of some kinds of procedures is tied to the duty to pay the fees for the procedures. This is the main limitation for filing the unfounded applications.

Many complications are concerned with the legal arrangement of delivering of the documents. The problems are concentrated mainly to the obsolete or fictitious addresses and cooperation with the postal services in foreign countries. Moreover, the regulation of the electronic delivery is established in the Law no 305/2013 Coll. on the electronic means of performance of the competences of the public authorities and amending certain other acts (the Law on E-Government) as amended. This is not appropriate because the whole regulation of delivering in two general acts is very unclear.

The responsible subjects for the evidence are administrative authorities. They have to collect sufficient evidence for finding of facts. The participants of the proceedings shall also propose the evidence for the supporting of their statements. Nevertheless, the breach of this obligation is not sanctioned. Moreover, the participants shall support only their statements but the administrative authorities are responsible for the objectivity of finding the facts.

8 For instance, the head of the central administrative authority or mayor of the municipality cannot be biased.

9 See in details pages P. Škultéty, Účastníci správneho konania, súčasný právny stav, návrhy do budúcna, [in:] Všeobecné správne konanie, Bratislava 2010, pp. 101-105. 
The Code lays down only some means of evidence. These are witnesses, experts, documents and survey. The other means of evidence are allowed if they clarify the facts and are obtained under the law.

This part regulates also the formalities for the decisions. The Code does not distinguish between different kinds of decisions. It means that every decision, which is issued according to the Code has the same formalities. There are also established the terms for decisions. The administrative authorities shall decide immediately. If it is not possible, the administrative authorities shall decide within 30 days. ${ }^{10}$ This term can be prolonged for 60 days. In particularly difficult procedures can be this term longer. These terms have a special position in the legal order. Despite the fact, that they are laid down by law, their expirations do not have an impact on the decisions in the administrative procedures. ${ }^{11}$ The costs of the proceedings are borne by the administration. The participants borne their costs. The legal regulation gives the power to the administrative authorities to decide about the duty to repay the costs caused by a particular subject. ${ }^{12}$

The Fourth part regulates the remedies, which are divided into ordinary and extraordinary ones. The legal regulation of ordinary remedies involves the appeal. The right to file an appeal is constructed too widely. This remedy may be used against every decision of first instance authorities. The exceptions from this rule have to be laid down in the special laws. ${ }^{13}$ The participants do not have the duty to state the reasons for filing an appeal. The appeals shall only contain which decisions are challenged. The appellate bodies shall to examine the all factual or legal defects of the first instance administrative decisions.

The appellate bodies have the same legal measures as the first instance administrative bodies. They can collect the new evidence and add the procedure with the new procedural steps. In the situation of defects in law or facts, the appellate bodies should carefully consider if they repair the first instance decisions and procedure or return the whole matter to the first instance administrative bodies. This task is very important. If the appellate bodies repaired all errors of the first instance administrative bodies, the first instance administrative bodies could relieve of their accountability for the procedures and the decisions. This consideration shall be done under the principle of quickness and the principle of procedural economy.

The appellate bodies are usually the closest superior bodies. The Code establishes some differences in appellate procedures against the decisions of central administrative bodies. Due to the lack of superior authorities, the appellate bodies

10 This term is considered very often for the common term for activity of administrative authorities also from the public.

11 See for instance the decision of Supreme Court of the Slovak Republic of 21 January 2009, procedure number 6 Sžo 76/2008 (published in the web-site https://www.nsud.sk/data/ att/8763.pdf, accessed: 1.04.2020).

12 For instance, if the witness does not come to the oral hearing without excuse.

13 See details Section 53 of the Code. 
are the heads of the central administrative bodies. They decide on the base of the recommendations of special committees. The members are appointed by them.

The extraordinary remedies are retrial and reviewing a decision outside the appellate proceedings. The main difference between these kinds of extraordinary remedies is that the retrial should react to the facts which occur after issuing of the decision and the reviewing a decision outside the appellate proceedings should be used to eliminate of the inherent illegalities of the decisions. ${ }^{14}$

The other characteristic feature of reviewing a decision outside the appellate proceedings is that the whole procedure starts on the base of the activity of the closest superior body. This body has the power to review the legality of every decision in a three-year term since entering into force. If this decision has legal errors, it can be changed or canceled. This legal framework is a very strong measure of the higher public authorities to enter the proceedings. It also constitutes the interference to the principle of legal certainty.

The Fifth part regulates the enforcement of particular acts of administrative authorities. These acts are decisions, settlements which are approved by the administrative authorities and the lists of default payments prepared by the administrative authority. The basic conditions for enforcement are that these acts are in force and include obligations that were not fulfilled voluntarily. At the beginning of the proceedings, there is the possibility to decide, if the enforcement will be performed by the administrative authority or by the bailiff. These two options are equal. It is difficult to say, which kind of enforcement is better. The Code regulates only the enforcement by administrative authorities. The enforcement by bailiffs is regulated by the Law no 233/1995 Coll. on bailiffs and their activities (Enforcement Code) and on amendments on certain laws as amended. The bailiffs have more manners for the performance of the decision. ${ }^{15}$

\section{The relation between legal institutions on administrative proceedings and the model of judicial review}

The right to review the decisions of administrative authorities is based on Article 46 $\$ 2$ of the Law no 460/1992 Coll. Constitution of the Slovak Republic as amended. Pursuant to this provision any person who claims his or her rights to have been denied by a decision of a body of public administration may come to court to have

14 To the remedies see in detail R. Jakab, P. Molitoris, M. Jurko, Správne právo procesné, Košice 2014, pp. 188-218.

15 For instance, the administrative authority does not have the power to divide the movable or immovable property in the enforcement procedure. 
the legality of the decision reviewed, unless otherwise is provided by the law. The review of decisions in matters regarding the fundamental rights and freedoms, however, shall not be excluded from the jurisdiction of courts. ${ }^{16}$

This legal regulation factually stipulates that every decision of administrative authority can be reviewed by the courts. The exemptions from this rule may be laid down only by special laws. This concept enables to control a wide range of administrative decisions. Furthermore, there is no list of particular kinds of decision. Therefore the judges shall firstly examine at the beginning of the trial, if the acts have the nature of a decision. Secondly, they shall examine, if the right to review is not excluded by special law. ${ }^{17}$

The judicial review of the acts and activities of public administration is established in the Law no 162/2015 Coll. Administrative Judicial Code as amended. Pursuant to this law, the general courts ${ }^{18}$ have jurisdiction in matters of administrative justice. Slovak Republic has not created special administrative courts. Administrative justice proceedings is built basing on the principle of one instance proceedings. The holders of material competency are usually the regional courts but the Administrative Judicial Code gives the power to act in particular cases to the district courts ${ }^{19}$ or the Supreme Court of the Slovak Republic. ${ }^{20}$

The Administrative Judicial Code lays down two extraordinary remedies. The first of them is a cassation complaint. It is possible to lodge it against the decisions of regional courts. The power to decide about cassation complaints has the Supreme Court, which has the status of the court of cassation in this proceedings. The grounds of the cassation complaints are stated widely. Pursuant to Section $440 \$ 1$ Subsection h) of the Administrative Judicial Code the Supreme Court shall review also the decisions of regional courts because of defects in the legal consideration of particular cases. This provision allows to lodge a cassation complaint against every adjudication of regional courts in matters of administrative justice. The second extraordinary remedy is an action for retrial. This remedy was provided by the

16 The English version of the Constitution of the Slovak Republic is published in the web-side https://www.prezident.sk/upload-files/46422.pdf (accessed: 20.01.2020).

17 See in detail M. Čič et al., Komentár k Ústave Slovenskej republiky, "Matica Slovenská" 1997, pp. 235-236.

18 The general courts network is built hierarchically. It consists of 54 districts courts (okresné súdy), 8 regional courts (krajské súdy) and the Supreme Court of the Slovak Republic (Najvyšší súd Slovenskej republiky). The system involves also the Specialised Criminal Court (Špecializovaný trestný súd) which has the status of the regional court.

19 These courts have jurisdiction only in some cases which are connected with the control of performance of the right to stand for the election. The material competency of the district courts is laid down in Article 12 of the Administrative Judicial Code.

20 This court is competent for instance in matters of reviewing decisions of the Committee of National Council of the Slovak Republic for the Review of Decisions of the National Security Authority. The material competency of the Supreme Court of the Slovak Republic is established in Article 11 of the Administrative Judicial Code. 
Administrative Judicial Code as the new one and there is the presumption that it will be applied rarely. The main aim of this remedy is to repair the factual situation when the European Courts ${ }^{21}$ decide in contrast with the prior administrative courts' judgements. ${ }^{22}$

The courts usually decide in panels of three judges. Some kinds of cases are decided by one judge ${ }^{23}$ or five judges. ${ }^{24}$ Pursuant to Section 24 of the Administrative Judicial Code the judge itself decides in matters before district courts. The judges in the Supreme Court decide in panels of three judges. The novelty in the legal regulation is Grand Panel which consists of seven judges. ${ }^{25}$

The judicial review is based on the principle of cassation. Administrative courts do not have the merits review competency. They can only cancel the decision and return the case back to the administrative authorities. This should emphasize the relationship between administrative justice and public administration. Procedure before administrative courts does not follow-up the procedure before administrative authorities. According to Slovak legal regulation, administrative justice is not part of administrative procedure. It is a separate system of control of public administration which should be complied with Article $46 \$ 1$ of the Constitution of the Slovak Republic. The cassation principle is not applied in every kind of judicial proceedings. Some of them have the specific legal regulation, which contains the elements of appellate principle. ${ }^{26}$ These legal elements violate the borders between the public administration and administrative justice and makes the administrative justice the successor of administrative proceedings.

\section{The influence of the Austrian codification idea on the shape of contemporary legal solutions}

As the laws regulating the administrative proceedings in the Austria-Hungarian Monarchy were in force until the adoption of the Regulation no 8/1928 Coll., after the establishment of the Czechoslovak Republic there were different legal

21 The European Court of Human Rights and the courts of the European Union.

22 According to my knowledge this remedy has not been used in the Slovak Republic.

23 For instance, in matters of administrative sanctions. See in detail Section $23 \S 2$ of the Administrative Judicial Code.

24 The five judges panel is applied in the Supreme Court of the Slovak Republic in matters in which the Supreme Court of the Slovak Republic decide in the first instance.

25 The matters in jurisdiction of this panel are established in Section $22 \S 1$ of the Administrative Judicial Code.

26 For instance, the proceedings in matters of administrative sanctions or in matters of social security. 
regulations in the Czech part and in the Slovak one. The Austria-Hungarian Monarchy, as the union of two states, had two legal systems. The Czech part belonged to Austria and the Slovak part belonged to Hungary. The basis for the contemporary legal regulation was done by Regulation no 8/1928 Coll., modeled mainly on the legal regulation which had been in force in the Austrian part of the Austria-Hungarian Monarchy. The reason for this conclusion is that Section $135 \$ 2$ of this Regulation mentioned the main laws which should be cancelled. Most of these laws included the legal order of the Austrian part of Austria-Hungarian Monarchy.

The legal institutions of these times might be found also in the Administrative Procedural Code. The comparison of the previous legal regulations with the Code shows that there is very strong historical tradition which is visible in the current legal regulation. All these facts allow us to state that contemporary legal solutions were fundamentally influenced by Austrian codification. The legal tradition strongly influences the Slovak law and it might be presumed that it will influence significantly the development of legal regulation of administrative proceedings in the future.

\section{The impact of European law on the activities of the national legislature and judicature}

As it was mentioned above, the Administrative Procedural Code was adopted over 50 years ago and its amendments were not significant. Most of them contained only "cosmetic" changes. Consequently, the standards of European law are transposed mainly through the courts' case-law. This involves also many problems, because the Slovak law system is based on the written law. Unfortunately, the reaction of our legislative authorities to the requirements of the European law is too slow and not sufficient. The problem was reflected mainly in the area of administrative sanctions. The national legislation of the Slovak Republic has not reacted to the regulations laid down mainly in the Article 6 of the Convention for the Protection of Human Rights and Fundamental Freedoms (hereinafter referred to as Convention). This is the reason why also theory draws attention to the need for the new legal regulation in this area. ${ }^{27}$

27 See for instance M. Srebalová, Zákaz reformatio in peius, dôvody jeho uplatnenia pri správnom trestaní a možnosti jeho právnej úpravy, [in:] Právna úprava správneho trestania, Bratislava 2015, pp. 62-72. 


\section{Openness to innovation - does the tradition or the modernization aims prevail in the actions of the legislature activities?}

As it was mentioned in the first part of this chapter, the Administrative Procedural Code was amended ten times. The most significant one was the amendment adopted by Law no 527/2003 Coll. The amendments influenced only particular regulations, not bringing the new system. It is rare in the legal system of the Slovak Republic that one act is valid for more than fifty years with only a few changes. It would be very difficult to find other similar examples in the new Slovak legal history. Of course, there were attempts of new codification of administrative proceedings. ${ }^{28}$ However, the official draft of the new law has not been announced.

The long-term tradition also strengthens the preservation of the Code. Furthermore, this act is quite short, simple for reading and well-known. These elements also support the tradition. Here exists also a bit of sentiment because most of the members of public administrative authorities apply the Code in decision-making procedures for the whole professional life. A new legal act causes new problems connected with its interpretation plus the need to learn and understand it. Despite these facts, it would be interesting to monitor the development of the general legal regulation of administrative proceedings in the future.

\section{Codification of administrative proceedings and decodification trends}

Despite the long-term tradition of Code, the decodification trends are also visible. Special laws exclude the use of Code in these proceedings quite often. It is for instance in tax matters, ${ }^{29}$ some kinds of social matters, ${ }^{30}$ public services, ${ }^{31}$ etc. On the other hand, this law is still applied in many decision-making proceedings because of

28 See for instance M. Vrabko, Prečo sme sa rozhodli novelizovat' zákon č. 71/1967 Zb. o správnom konaní, [in:] Všeobecné správne konanie, Bratislava 2009, pp. 13-18.

29 See in detail Section 163 of the Law no. 563/2009 Coll. on tax administration (Tax Administration Code) and on amendments to certain laws as amended.

30 See in detail Section $172 \S 1$ of the Law no. 461/2003 Coll. on social insurance as amended (hereinafter referred to as the Law on Social Insurance).

31 See in detail Section 247a of the Law no. 73/1998 Coll. on the civil service of members of the Police Force, the Slovak Intelligence Service, the Court Guards and Prison Wardens Corps and the Railway Police, as amended. 
the wide scope of it. The advantage of applying of the Code is mainly the complexity of legal regulation. It is also important, that this law does not cover only the whole proceedings, but also it lays down the main principles. ${ }^{32}$ Of course, the main principles shall apply also when the written law is silent. However, the principles stated in the laws increase the legal certainty of the whole proceedings. The included principles shall be applied by all subjects of the proceedings without the complex discussions about the approppriateness of their use in particular situations.

\section{Codification of administrative proceedings and practice}

The Code has been in force for more than 50 years without significant amendments. This is connected with the tradition, but also with not very good ability to react to the new requests and trends. It does not regulate the accelerated procedures or legal institutions which could simplify the proceedings. It does not contain any legal institutions of alternative dispute resolution, apart from the settlement approved by the administrative authority, which can be concluded in some kinds of proceedings.

Also, the academic discussion is focused mainly on the common legal instruments and seems to be feared of entering into "uncharted waters". According to the knowledge of the author of this chapter, there was only one publication ${ }^{33}$ dealing with the alternative dispute resolution. It is a pity that this publication did not launch a discussion about the modernization of administrative proceedings.

\section{Successes and failures - what was not achieved?}

The Administrative Procedural Code regulates only the decision-making procedures. Other kinds of procedures do not have the general legal regulation. The need of such regulation might be subject of a discussion. It could be questionable

32 For instance, the Law on Social Insurance does not contain any principles in the Third Part regulating the proceedings.

33 This publication is P. Molitoris, Konsenzuálne prostriedky alternatívneho riešenia sporov v správnom konaní, Košice 2016. 
if the detailed legal regulation of these kinds of proceedings were useful. Nonetheless, establishing the basic principles in these kinds of procedures may support the legal certainty. Also administrative contracts do not have their own general legal regulation. They are usually concluded according to the special laws and main acts of civil law. Consequently, depending on their character, they are described as public or private. The importance of the general legal regulation could be also seen in establishment of basic principles. Section $3 \$ 7$ of the Code lays down the obligation to use the main principles of this act also in the procedures which do not have the decision-making nature. Nonetheless, this provision involves the duty to apply the Code principles only in the procedures of excercising public power in unilateral way. It could be questionable, if the main principles for decision-making procedures are suitable for other kinds of proceedings. The very important task in the future will be also the synchronization of the Code with the EU law. The legislation should react especially to the requests of Article 6 of the Convention for the Protection of Human Rights and Fundamental Freedoms in the administrative proceedings which naturally falls to the kinds of cases established there.

\section{General conclusions and comments on the development prospects of law on administrative proceedings}

Law on administrative proceedings is developed on the basis of the Administrative Procedural Code. This kind of law is unusual for the legal system of the Slovak Republic and can be marked as the symbol of tradition and stability, but it does not reflect all contemporary needs. It is now very hard to say, how these defects will be solved. Either the special laws would reduce the scope of the Code or replace it with a new act.

The consideration of the prospected changes within the regulation on administrative proceedings will be, for sure, influenced by the long-term tradition of this law and its familiarity of it within the public administration. If the new law was adopted to replace the Code, such law would be based on the previous legal regulation. It is unlikely to wait for the essential changes in the new legal regulation.

The Administrative Procedural Code is an extraordianry example of a legislation in the Slovak legal system with over fifty years binding force without significant amendments. It is also important to mention that this law was valid in the previous regime and remained also valid now. The reasons for this can be found in the times when this legal regulation was adopted. The laws used to be shorter, more general and ensured the consideration of the administrative authorities. 
Furthermore, the Code is written with the simple language. It allows all people to understand the particular provisions and the whole context.

The meaning of the Code is strengthened by the long-term tradition too. The administrative authorities use it daily for years and know it very well. Despite working on the new general legal regulation of administrative procedure, the Code still remains in force. The strong position of the Code also ensures the principle of legal certainty. This well-known and wide applicable legal regulation is stable for many years.

Despite these advantages, it is possible to find more arguments for new legal regulation. According to the opinion of the author of this chapter, the Code does respond to all changes in society, scientific and technical progress. The Code does not include any provisions which could simplify or accelerate the administrative procedure. This law establishes only one kind of procedure and one kind of decision. This kind of decision shall be issued, when the administrative authority decides about the rights and duties of the particular persons in proceedings. There is a lot of space for simplifications. For instance, it is questionable if there is still the requirement to issue the decision consisting of the same elements in all kinds of situations. It could be taken into consideration if the procedural decisions have to include the same formalities in comparison with substantial decisions. It will be also possible to think about the division of the procedures into regular and accelerated procedures, etc.

The simplification of the procedures is connected also with possibilities to use the new technologies within the performance of so-called e-government. The e-government is regulated in special laws, which is a disadvantage of the system. The Code should react to the modern trend. The use of special laws soften the position of this act which should offer the complex and clear legal regulation. The general legal regulation of administrative proceedings does not also meet all the standards of the EU law. It was mentioned that the Code does not fulfill the requirements, which are established mainly in Article 6 of the Convention. Moreover, this law does not distinguish between the procedures covered by this provision.

The Code contains only the legal regulation of decision-making procedures within the application of the law. It does not regulate other procedures or forms of public administration activities. Such general provisons do es not exist in separate laws. For instance, the legal order of the Slovak Republic does not contain the general legal regulation of the concluding of administrative contracts.

It is important to mention that lack of general legal regulation could be partly solved by some special laws, for instance, concerning administrative sanctions, in compliance with the Convention. It would be possible to adopt the laws which could regulate other forms of procedures. Changes within the Code seem to be worth considering also, for example introducing legal regulation of special procedures. Nonetheless, such discussions have started recently and abovementioned changes would not be possible without political will. This means that the task for 
the theory will be to propose new legal regulation and persuade the competent authorities about the need of it. It is very hard to presume how the Code will change or if the new code will be created. It would need cooperation of legal theory and praxis and would take some time. A short term solutions should not be accepted, but only a stable, understandable and general act, which will continue in the tradition of the general legal regulation of administrative proceedings.

\section{Republika Słowacka}

Postępowanie administracyjne na terytorium Słowacji, jako części składowej nowego państwa utworzonego w 1918 r. - Czechosłowacji, zostało po raz pierwszy skodyfikowane $\mathrm{w}$ formie rozporządzenia rządowego $\mathrm{nr}$ 8/1928 o postępowaniu w sprawach należących do władz politycznych. Wzory dla tej regulacji stanowiły orzecznictwo sądowe i reguły praktyki administracyjnej z czasów Monarchii Habsburskiej oraz nowo utworzonego Najwyższego Sądu Administracyjnego. Pewne kategorie postępowań pozostawały poza zakresem tego unormowania. Dwie kolejne kodyfikacje postępowania administracyjnego także miały postać rozporządzeń rządowych, z 1955 i 1960 r. Nie ulega wątpliwości, że pozostwawały one pod wpływem ideologii socjalizmu i przyjmowanych wówczas założeń ustrojowych. Akty te cechowała trwałość, nie podlegały bowiem one istotnym zmianom.

Trwałością cechuje się także wciąż pozostający w mocy uchwalony w Czechosłowacji 1967 r. Kodeks postępowania administracyjnego. Zakres jego zastosowania jest szeroki, ale niewyczerpujący; uzupełniają go przepisy odrębne, zawarte $\mathrm{w}$ innych ustawach. Relacja pomiędzy uregulowaniami szczególnymi a przepisami kodeksu ukształtowana jest na zasadzie subsydiarnego zastosowania tego ostatniego. Kodeks składa się z sześciu części obejmujących uregulowania w przedmiocie: zasad ogólnych, podmiotów postępowania, instytucji techniczno-procesowych, środków ochrony procesowej, wykonania decyzji oraz postanowień przejściowych i końcowych. Wydawanie wszystkich decyzji poddał on temu samemu reżimowi. Ich wykonywanie podlega natomiast zróżnicowanym regułom. Niektóre z nich mogą być eegzekwowane także przez komorników, nie zaś wyłącznie w ramach egzekucji administracyjnej.

Poza tradycyjnie rozumianym odwołaniem od decyzji administracyjnej, w kodeksie słowackim przewidziano także nadzwyczajne środki jej wzruszenia. Zaliczono do nich wznowienie postępowania i zaskarżenie decyzji poza postępowaniem odwoławczym.

Koszty postępowania administracyjnego pokrywane są przez organy prowadzące postępowanie. Organowi administracji przysługuje wszakże prawo obciążenia nimi podmiotu, którego zachowanie takie koszty wygenerowało. 
Większość decyzji administracyjnych wydawanych na Słowacji podlega kontroli sądów powszechnych. Sprawowanie tej kontroli deklaruje art. $46 \$ 1$ słowackiej Konstytucji. Postępowanie przed sądem jest jednoinstancyjne, ale rozstrzygnięcia sądowe mogą być podważone $\mathrm{w}$ drodze nadzwyczajnych środków prawnych, w tym kasacji do Sądu Najwyższego oraz w trybie wznowienia postępowania. Kompetencja w zakresie orzekania w sprawach ze skarg na decyzje administracyjne przysługuje sądom regionalnym, a w pewnym zakresie sądom okręgowym i Sądowi Najwyższemu. W systemie słowackim przyjęto zasadę kasacyjnego orzekania $\mathrm{w}$ ramach sądowej kontroli. W ocenie autora rozwiązania te nie spełniają standardu europejskiego - rzetelnego procesu sądowego, przewidzianego w art. 6 ust. 1 europejskiej Konwencji o ochronie praw człowieka i podstawowych wolności.

Autor zwrócił uwagę, że postępowanie administracyjne na Słowacji wciąż pozostaje pod silnym wpływem wzorców austriackich. Wskazał, że obecnie słowacki system prawny determinowany jest również $\mathrm{w}$ jakimś stopniu przez prawo unijne, choć prawo krajowe nie w pełni odzwierciedla wymagań utożsamianych ze standardami europejskimi. W jego ocenie, na Słowacji tradycyjne instytucje prawa procesowego zdecydowanie przeważają nad nowoczesnymi rozwiązaniami. Konsekwencją stabilności słowackiego kodeksu postępowania administracyjnego jest obniżający się poziom adekwatności tej ustawy do potrzeb praktyki. Jego zdaniem, regulacja słowackiego postępowania administracyjnego wymaga zreformowania. Za pilne zadanie uznał on przede wszystkim ukształtowanie konstrukcji sprzyjających uproszczeniu i przyspieszeniu postępowania, a także realizacji idei i standardów prawa unijnego.

(tłum. Joanna Wegner)

Juraj Vačok, Doc. JUDr. PhD. An associate professor in the Department of Administrative and Environmental Law of the Faculty of Law of the Comenius University in Bratislava. His research activities are focused on the administrative proceedings and administrative justice. He is author of more scientific articles, one monograph and co-author of more textbooks. Since the Year 2006 he works also in the Law Firm Čakvári, Matkovčík, Vačok and partners in Bratislava. He is a member of two minister's advisory committees. 



\section{Chapter XI Slovenia}

Bruna Žuber, Dr, Assistant Professor

University of Ljubljana, Faculty of Law

bruna.zuber@pf.uni-lj.si

(iD) https://orcid.org/0000-0003-1137-4561

\section{Stages in the evolution of the law on administrative procedures - from the first codification}

History has shown a continuous development of different administrative procedural regulations valid in the territory of Slovenia already in states preceding its independence in $1991 .{ }^{1}$ Until the end of 1918, Austrian law was applied in most of the Slovenian territory. The administrative procedure rules were laid down by decrees and ministerial orders, and some laws (for instance Law on legal remedies as of May 12, 1896). In addition, administrative authorities had to comply with the 1903 Körber's Order requiring of them to grant parties' requests when possible, justify their decisions, and allow access to files. ${ }^{2}$ In 1926, Dr. Rudolf Andrejka commented on the state of the Austrian administration prior the codification of administrative procedural rules with the following words: "The lack of uniform administrative procedural rules caused that the Austrian administration operated slowly, yet relatively well". ${ }^{3}$

Even after the establishment of the Yugoslav country, Austrian law continued to be applied on the territory of Slovenia. On the basis of the Vidovdan Constitution (1921) the Law on the State Council and on Administrative Courts was adopted

1 E. Kerševan, The Principle of Effective Legal Protection in Administrative Law in Slovenia, [in:] The Principle of Effective Legal Protection in Administrative Law: A European Comparison, eds. Z. Szente, K. Lachmayer, London, New York 2017, p. 266.

2 R. Godec, Razvoj ureditve upravnega postopka v Sloveniji in Jugoslaviji, [in:] Vloga upravnega postopka v samoupravnem socializmu, Ljubljana 1977, p. 90.

3 R. Andrejka, Nove smeri v našem upravnem postopanju, "Slovenski pravnik" 1926, p. 15. 
in 1922. This Law significantly affected the administrative procedure, since it introduced the principle of two instances of the administrative procedure and judicial protection in case of silence of administrative authorities, which constituted a deviation from Austrian law. ${ }^{4}$ In spring 1923, the Government of the Slovenian Province issued a code called Postopnik za obča upravna oblastva, which was used for around eight years until the adoption of the Law on General Administrative Procedure in 1930. Despite its temporary nature, and the fact that it was issued by an authority with very limited competence, this abstract administrative act was very important, since before that no other act which would comprehensively regulate administrative procedure had been adopted in the world. Although conceived as an internal instruction to administrative authorities, the act reflected the actual state of the administrative procedure regulation in Slovenia in the years immediately following World War I. ${ }^{5}$

The first law on general administrative procedure in the world was adopted by the Republic of Austria in 1925. Shortly afterwards, in 1930, Yugoslavia adopted the Law on General Administrative Procedure that had been in force since February 26, 1931. Its authors followed the example of the Austrian administrative procedure regulation, while at the same time striving to bring the new Yugoslavian regulation closer to the civil procedure. ${ }^{6}$ The Law was repealed at the end of World War II due to adoption of an ordinance on abrogation and repeal of all legal regulation issued between the occupation. The new Law Regulating the General Administrative Procedure was adopted in 1956 and came into force on April 19, 1957. It contained some basic changes in relation to the 1930 law, mostly because of the application of all principles of modern procedural law. ${ }^{7}$ The law was amended several times (in 1965, 1977, 1978, and 1986), however, the basic procedural provisions remained the same. ${ }^{8}$ As the territory of Slovenia was part of Yugoslavia, both above-mentioned laws applied in Slovenia as well.

By declaring its independence in 1991, Slovenia took over the Yugoslav Law Regulating the General Administrative Procedure. On the basis of Article 4 of the Constitutional Act Implementing the Basic Constitutional Charter on the Independence and Sovereignty of the Republic of Slovenia, ${ }^{9}$ the Yugoslav law continued to be applied insofar as it did not contradict the new Slovenian legal order.

4 R. Godec, Razvoj ureditve..., p. 92.

5 More on this see: ibidem, pp. 93-104.

6 Ibidem, p. 105.

7 L. Vavpetič, Introduction, [in:] The Yugoslav Law on General Administrative Procedure, Beograd 1961, p. 13, 37.

8 I. Koprić, Administrative Procedures on the Territory of Former Yugoslavia, http://www.sigmaweb.org/publications/36366473.pdf (accessed: 15.01.2020), p. 2 and E. Kerševan, V. Androjna, Upravno procesno pravo: Upravni postopek in upravni spor, Ljubljana 2017, p. 34. 
New General Administrative Procedure $\mathrm{Act}^{10}$ (hereinafter referred as GAPA) was adopted in 1999. The new Act was drafted to be a continuation of the former administrative procedure regulation with certain updates and further developments in the content. GAPA was amended eight times until today, while the concept of the Act remained unchanged.

\section{The binding force of the law on administrative procedure and the issue of subsidiary application of provisions regarding general administrative procedure}

GAPA determines rules on general administrative procedure. Pursuant to the existing regulation, GAPA applies to all a administrative matters (either fully or subsidiary) and even to non-administrative public matters, that are not regulated by a special procedure (special or appropriate application).

GAPA fully applies to the procedures of administrative and other state authorities, self-governing local community authorities and other bodies exercising public powers ${ }^{11}$ where these authorities in administrative matters decide on the rights, obligations or legal benefits of individuals, legal persons and other parties. ${ }^{12}$ The stated authorities have to act on GAPA in cases when their decision-making in administrative matters will create, abolish, or change the public law relations between the authority, and the party to the procedure. It is therefore crucial, that the definition of when administrative authorities are required to act on GAPA, is based on the definition of the concept of administrative matter. If there is no administrative matter, it is not possible to conduct an administrative procedure, nor issue administrative decisions. ${ }^{13}$ According to Article 2 of GAPA, the administrative matter is defined as deciding on a right, obligation of a natural or legal person or other party in the field of administrative law. It is further provided that a case is deemed to be an administrative matter: i) if a law provides that an authority conducts an administrative procedure in a certain case, or ii) if for the purpose of protecting the

10 Official Gazette no. 80/99 as amended.

11 In line with $\S 2$, Article 1 of GAPA public authorisation to conduct procedures and decide in administrative cases should be conferred by a law, while the authorisation to conduct procedures and decide in administrative cases in a self-governing local community should be conferred by an ordinance adopted by the self-governing local community council.

12 Article 1 GAPA.

13 E. Kerševan, V. Androjna, Upravno procesno pravo..., p. 39. 
public interest this can be deduced from the nature of the case. This means, that the application of administrative procedure rules is not only mandatory when explicitly required by the substantive regulation, but also when this is not provided by the regulation, which instead provides that the competent authority decides on a right, obligation, or legal benefit of a person, and that an administrative matter is consi-dered as such because of its very nature. ${ }^{14}$

The specifics of single administrative areas in Slovenia are not such as to require a comprehensive special regulation of the administrative procedure for individual areas, which would exclude the general administrative procedure rules. Generally, individual administrative areas only require partial deviation from general administrative procedure rules, required by the principle of effectiveness. This is why GAPA provides for a subsidiary application. ${ }^{15}$ Subsidiary application of GAPA means that in administrative areas for which a separate law determines a special administrative procedure, the provisions of such separate law apply. Furthermore, GAPA subsidiary applies when single issues regarding administrative procedure in a specific administrative area are regulated by a separate law differently from GAPA, if this is necessary for proceeding in such administrative area. However, in both cases the provisions of GAPA apply to the procedure in all issues which are not regulated by a separate law. ${ }^{16}$ Only a law can determine a special administrative procedure or single issues that are regulated differently from GAPA and it can only do so if such a regulation is necessary for proceeding in a particular administrative area.

Besides full and subsidiary application of GAPA, provisions of GAPA can also apply mutatis mutandis in other public law matters which cannot be considered as administrative matters, if these matters are not regulated by a special procedure. ${ }^{17}$ Mutatis mutandis application means that individual cases will only see the application of those GAPA provisions that are suitable in a particular case. ${ }^{18}$ In practice, major dilemmas arise regarding mutatis mutandis application of GAPA (it is not clear which concrete cases GAPA covers, nor which parts or institutions are not appropriate in the concrete case) and thus mutatis mutandis application of GAPA is seldom indicated by case law. ${ }^{19}$

14 Ibidem, p. 46.

15 In practice GAPA subsidiary applies in customs matters, tax matters, inspection matters, construction matters, etc.

16 Article 3 GAPA.

17 In practice GAPA mutatis mutandis applies in misdemeanour cases, in civil servants law, etc. Slovenian legal theory established some conditions that have to be met for mutatis mutandis application. On this see: E. Kerševan, V. Androjna, Upravno procesno pravo..., p. 58.

18 Ibidem.

19 P. Kovač, Modernizing Administrative Procedural Law in Slovenia as a Driving Force of Efficient and Good Administration, "NISPAcee Journal of Public Administration and Policy" 2011, vol. 4, no. 2, p. 45. 


\section{Distinctive institutions and peculiarities of the law on administrative procedures}

GAPA is divided into six separate parts. The first governs general provisions, namely fundamental principles, jurisdiction, parties and their representation, language of the procedure, communication between authorities and parties, service, time limits and hearings, reinstatement of a case, maintaining order in the procedure, and costs of procedure. The provisions of the first part of GAPA apply in all phases of administrative procedure, at first and second instance, and in procedures employing extraordinary legal remedies and enforcements. The second part, constituting the central part of GAPA, governs the first instance procedure and contains provisions on the initiation of procedure, declaratory proceeding, evidence and decisions in administrative procedure. Part three of GAPA governs ordinary and extraordinary legal remedies. Part four governs enforcement of obligations, imposed on duty holders by administrative decisions or orders. The peculiarity of GAPA is explicit regulation of control over application of GAPA and special administrative procedures (part five of GAPA).$^{20}$ These provisions were introduced in 2010 in order to strengthen proper implementation of administrative procedure. ${ }^{21}$ The last part of GAPA is of more technical nature. It governs implementation of GAPA, and its transitional and final provisions.

Administrative procedure rules are based on some of the generally applicable fundamental legal principles, which are used in all phases of administrative procedure. Their application may only be restricted or excluded by an express statutory provision. GAPA regulates the following fundamental principles of administrative procedure: the principle of legality, ${ }^{22}$ the principle of protection of the rights of parties and protection of public benefits, ${ }^{23}$ the principle of the material truth ${ }^{24}$ the principle of hearing the party, ${ }^{25}$ the principle of free evaluation of evidence, ${ }^{26}$ the obligation

20 Supervision is conducted by the administrative inspection service (Article 307 GAPA).

21 On this see P. Kovač, [in:] Comparative Study: Legal Remedies in Administrative Procedures in Western Balkans, Danilovgrad 2016, p. 60.

22 Article 7 GAPA.

23 Article 8 GAPA. This principle obliges the authority to ensure that the ignorance of any party or other participants in the procedure does not lead to the loss of their rights under law. It also requires to comply with the rule of proportionality when deciding on the rights or imposing obligations in administrative procedure.

24 Article 8 GAPA. This principle requires the true facts of the case are determined and insists on finding all relevant facts for a lawful and correct decision.

25 Article 9 GAPA.

26 Article 10 GAPA. 
to tell the truth and fair use of rights, ${ }^{27}$ the principle of independence in deciding, ${ }^{28}$ the right to appeal, ${ }^{29}$ the principle of effectiveness and cost efficiency. ${ }^{30}$ Some other principles also apply to single phases or steps of the administrative procedure (e.g. the investigative principle, the principle of publicity).

According to GAPA, an administrative procedure in the first instance can be initiated at the competent authority ex officio or on request by the party. ${ }^{31}$ Before issuing a decision, all facts and circumstances relevant for the decision have to be established and the parties should be given the possibility to protect their rights. This can be achieved in a summary fact-finding procedure or in a special fact-finding procedure. ${ }^{32}$ In a summary fact-finding procedure the principle of hearing the party is explicitly excluded, ${ }^{33}$ while in a special fact-finding procedure the party has the right to actively participate in a procedure. ${ }^{34} \mathrm{~A}$ person acting in an official capacity is required to establish the substantive truth, therefore GAPA gives them the power to act on their own motion to establish facts and exercise evidence regardless of how the procedure initiated (the investigative principle). However, this rule does not pose an obstruction for parties to submit facts and suggest evidence on their own.

Where the procedure is initiated on the request of the party or ex officio if this is in the interest of the party, and before reaching a decision no special fact-finding procedure is necessary, the competent authority must issue a decision and serve it on the party as soon as possible or in one month at the latest from the day it received a complete application for initiating a procedure, or from the day when the procedure was initiated ex officio. In other cases in which the procedure is initiated on the request of the party or ex officio if this is in the interest of the party, the competent authority must issue a decision and serve it on the party within two months at the latest. ${ }^{35}$ GAPA establishes the rule according to which, the decision is issued in writing containing all specified elements. ${ }^{36}$ Only in cases concerning emergency measures taken in the public interest, the competent authority may decide orally. ${ }^{37}$ With regard to

27 Article 11 GAPA. According to this principle the parties are obliged to tell the truth and fairly use the rights granted to them by GAPA or other acts regulating administrative procedure.

28 Article 12 GAPA.

29 Article 13 GAPA.

30 Article 14 GAPA.

31 Article 125 GAPA.

32 Article 138 GAPA.

33 Article 144 GAPA.

34 The party has the right to be heard on all circumstances and facts, the right to be heard on the proposals and evidence offered, the right to participate in evidence taking, the right to ask questions to other participants in the procedure, the right to be informed on the success of presenting the evidence and be heard thereon. On this see: Article 146 GAPA.

35 Article 222 GAPA.

36 Article 210 GAPA.

37 Article 211 GAPA. Even though the authority which has decided orally it must issue to the party a written decision within eight days of reaching the oral decision. 
this, it should be noted that according to the Slovenian administrative practice, every act, which contributes to a decision on a right or obligation of a party on the merits, regardless of the form in which the act was issued, is considered administrative decision. The fact, that a certain act fails to be issued in a form of a decision, indicates a violation of the procedural rules, which may mean that such act is unlawful. However, a defect in form cannot result in a decision being inexistent. ${ }^{38}$ Each administrative decision has to give reasons with only some exceptions expressly regulated by law (e.g. urgent matters, matters of minor importance). ${ }^{39}$

The appeal is the only ordinary legal remedy against a decision issued at first instance in general administrative procedure. ${ }^{40}$ In principle, the appeal has a suspensive effect and is decided by a superior administrative body. ${ }^{41}$ The persons entitled to appeal are those, who had a formal legal status of parties in the first instance proceedings and those who were not taking part in administrative procedure, if their rights or legitimate interests under public law are affected by the administrative decision. The administrative bodies cannot initiate the appeal procedure on their own motion. However, the decision can be appealed by state prosecutors or state attorneys even though they were not parties to the procedure if they claim that the administrative decision violates public interest. ${ }^{42}$ An appeal can be lodged against a first instance decision based on questions of fact, material law and procedural law. ${ }^{43}$ The "silence of administration" can also be grounds for an appeal based on a legal fiction that the party's application was rejected or that the procedural outcome in ex officio proceedings was unfavourable. ${ }^{44}$ The appellate body examines the decision in the part in which the appellant challenges it. ${ }^{45}$ In line with the principle of protecting objective legality, GAPA authorizes the appellate body to examine ex officio possible violations of both substantive and procedural law, even if they were not challenged by the appellant. The appellate body can annul the act even against the interests of the person who lodged the appeal, meaning ultra petitium in cases provided by GAPA. ${ }^{46}$ When deciding on appeal the appellate body

38 E. Kerševan, V. Androjna, Upravno procesno pravo..., p. 306.

39 Article 214 GAPA.

40 The exception to the right to an administrative appeal has to be expressly regulated by an act of a parliament and is applied in cases of decisions of independent regulatory authorities, where these decisions can be directly subjected to judicial review. On this see: E. Kerševan, The Principle of Effective..., p. 271.

41 Articles 230-234 GAPA.

42 Article 229 GAPA.

43 Article 237 GAPA.

44 Articles 222, 255 GAPA.

45 Article 247 GAPA.

46 On this see: E. Kerševan, The Principle of Effective..., p. 272. 
may annul a decision and refer the case back to the first instance authority for a new procedure. It may also change the challenged decision itself. ${ }^{47}$

There are several extraordinary legal remedies regulated by GAPA, namely the reopening of the procedure, annulment ab initio or modification of a decision concerning administrative dispute, the repeal and annulment of a decision through supervisory right, extraordinary annulment, nullity of decisions. In certain areas of administration extraordinary legal remedies can be regulated by other laws (e.g. Tax Procedure Act) ${ }^{48}$ In general extraordinary legal remedies can be used to remedy severe violations of material and substantial law as well as some errors in established facts.

\section{The relation between legal institutions on administrative procedures and the judicial review model}

In Slovenia, the judicial review of the legality of administrative decisions and actions of state authorities, local community authorities and other bodies exercising public powers is ensured in the administrative dispute. The fundamental procedural law in the field of administrative dispute is the Administrative Dispute Act (hereinafter referred as ADA). ${ }^{49}$ The action in administrative dispute does not stay the execution of the administrative act against which it was filed, unless otherwise provided by an act. ${ }^{50}$

Administrative dispute is not an extraordinary legal remedy within the administrative procedure. Instead, it is a judicial proceeding that is conducted separately from the administrative procedure. Despite this, administrative procedure and administrative dispute are closely linked, mainly because judicial control is exercised in administrative disputes over the correct application of GAPA rules in the procedure of issuing the administrative act. ${ }^{51}$

To indicate the institutional cohesion of administrative procedure and administrative dispute, there is an extraordinary legal remedy provided in GAPA, namely the annulment $a b$ initio or modification of a decision concerning administrative

47 GAPA, art. 246-255. More on the appeal procedure see: E. Kerševan, The Principle of Effective..., p. 272.

48 More on this see: E. Kerševan, The Principle of Effective..., pp. 272 and P. Kovač, [in:] Comparative Study..., pp. 100-105, 128-130.

49 Official Gazette RS no. 105/06, 107/09 - odl. US, 62/10, 98/11 - odl. US, 109/12 in 10/17 - ZPP-E.

50 Article 32 ADA.

51 Article 27 ADA. 
dispute. ${ }^{52}$ This extraordinary legal remedy allows the authority which issued a decision that was challenged in the administrative dispute, to annul or modify its decision up until the administrative dispute has been concluded, if it finds the action justified in its entirety. The purpose of this remedy is to improve procedural economy when it is obvious due to the assertions in the action that the plaintiff will succeed in the administrative dispute. ${ }^{53}$

ADA also provides for an action due to silence of administrative authorities. ${ }^{54}$ If the Administrative court finds the action justified it may decide on the matter by itself (if all conditions provided by law are met), it may instruct a competent authority what kind of administrative act to issue or, if the decision was not served, order the service of the decision. ${ }^{55}$ In all these cases, the Administrative court significantly interferes with the competence and legally guaranteed independence of authorities ruling in administrative procedures.

In case of a successful action, the Administrative court in the vast majority of cases annuls the disputed act and refers the case back to the responsible administrative body. ADA has introduced a legal obligation for administrative bodies to follow the reasoning of the court to raise the effectiveness of the judgement that annuls the unlawful administrative act. ${ }^{56}$ The ADA rules on the obligation of administrative authorities to follow reasoning of the court regarding the use of substantive law and the procedure, adopted by the court in an administrative dispute, represent a significant, yet constitutionally justified interference with the principle of independent decisionmaking of administrative authorities. ${ }^{57}$ In principle, the administrative bodies have to follow the legal reasoning of the court and in case they violate this obligation, the Administrative court in the subsequent administrative dispute can use its powers to decide in full jurisdiction. ${ }^{58}$ In practice, the Administrative court decides on dispute of full jurisdiction (this means that it changes the disputed act and gives a final decision on administrative matter) only in exceptional cases.

52 Article 273 GAPA.

53 On this see: P. Kovač, [in:] Comparative Study..., p. 128.

54 The party may initiate an administrative dispute on the basis of a legal fiction that the party's motion was rejected: i) if the appellate body does not issue its decision within two months or within a shorter period determined by an act, ii) if the first-instance authority does not issue a decision in a period determined by an act against which an appeal cannot be lodged and iii) if authority does not issue a final administrative act within three years of the beginning of the procedure. On this see Article 28 ADA.

55 Article 69 ADA.

56 E. Kerševan, The Principle of Effective..., p. 276, 277.

57 Article 64 ADA.

58 E. Kerševan, The Principle of Effective..., p. 277. 


\section{Influence of the Austrian codification idea on the form of contemporary legal solutions}

Austrian codification idea has influenced the Slovenian legal arrangement of administrative procedure. In Slovenia the regulation of general administrative procedures is based on the former Austrian and Yugoslav legacy. ${ }^{59}$

The Law on General Administrative Procedure of Yugoslavia, adopted in 1930, was based on the Austrian model. The new regulation of general administrative procedure in Slovenia continues to be based on the Austrian tradition of the general administrative procedure. ${ }^{60}$ Slovenian GAPA, adopted in 1999, took over most structural solutions of Yugoslav Law Regulating the General Administrative Procedure of 1986. Over the last 20 years there has been no major amendment of GAPA, neither in terms of extent nor in terms of subject matter.

\section{The impact of the European law on national legislature and judicature}

Slovenia became a full member state of the European Union (hereinafter referred as EU) on May 1, 2004. The national strategy for accession to the EU published in $1997^{61}$ devoted special emphasis to the significance of administrative procedural law. It defined the adoption of GAPA together with the judicial control of administration and the institution of ombudsman as a foundation of the democratic system for the protection of individuals against the possible abuse of power. ${ }^{62}$ Although major part of Slovenian legislation in the field of administrative procedural law complied with EU law before full membership in the EU, ${ }^{63}$ yet same national laws only later adopted EU standards and trends, encouraged particularly by the Action Programme for Reducing Administrative Burdens in the EU. For instance, in 2010 Slovenia adopted the Act on services in internal

59 P. Kovač, [in:] Comparative Study..., p. 57.

60 On this see also: I. Koprić, Administrative Procedures..., p. 2-3.

61 Poročevalec Državnega zbora RS no. 48/97 and 48/I/97.

62 More on administrative procedure in light of the national strategies see: P. Kovač, The Requirements and Limits of the Codification of Administrative Procedure in Slovenia According to European Trends, "Review of Central and East European Law" 2016, vol. 41, pp. 446-447.

63 For instance GAPA was adopted in 1999. The first ADA was adopted in 1997, the new ADA-1 was adopted in 2006. 
market, ${ }^{64}$ following the Directive $2006 / 123 /$ EC on services in the internal market, and thus provided the presumption of positive administrative act in case of administrative silence. ${ }^{65}$

Furthermore, the position of Slovenia as a member state of the EU has changed some very important aspects of our legal practice. First of all, the obligation to comply with EU law and the rule on the refusal to apply a national law or regulation which is deemed contrary to the European law, does not only apply to courts but also to all other national authorities, including the administration of the member states. This is an important novelty in the field of law application for Slovenian administrative authorities. In fact, the administrative authorities in Slovenia do not have the right to refuse to use of any national regulation even if in their opinion such regulations are in opposition to hierarchically superior national regulations. In such cases they can only inform a higher-ranking authority about the detected non-compliance. ${ }^{66}$ It can also be said that courts exercising judicial review over the work of the administration, intensively apply primary and secondary EU legislation. The preliminary ruling procedures, used to provide interpretation of EU law, are an important indicator of the intensity of the application of EU law. In fact, the majority of proposals for a preliminary ruling submitted by Slovenia to the Court of Justice of the European Union pertained to the field of administrative law. These proposals were submitted by the Administrative Court of the Republic of Slovenia and the Supreme Court of the Republic of Slovenia. ${ }^{67}$

64 Official Gazette RS no. 21/10.

65 See art. 11 of the Act on services in internal market. See also: P. Kovač, Effective Conflict Resolution in Administrative Proceedings in Slovenia: A Theoretical and Empirical Analysis, [in:] Alternative Dispute Resolution in European Administrative Law, Berlin and Heidelberg 2014, p. 389.

66 By comparison the courts in Slovenia must refuse to apply a regulation or a general act issued for the exercise of public authority if they deem a provision unconstitutional or unlawful and decide the case on the basis of the provisions of the Constitution or law (exceptio illegalis).

67 Altogether, Slovenian courts instituted 24 preliminary ruling procedures, 3 of which were initiated by the Administrative court, and 11 by the Administrative Department of the Supreme Court. On this see: https://www.sodnapraksa.si/?q=sklep\&database\%5BSEU\%5D=SEU \&rowsPerPage=20\&_submit=i\%C5\%A1\%C4\%8Di (accessed: 20.01.2020). 


\section{Openness to innovation - is the goal of modernization visible in the activities of the legislature?}

Most amendments of GAPA focused on promoting the efficiency of administrative decision-making and on the reduction of administrative burden.$^{68}$ Only a few amendments aimed to strengthen the procedural rights of the parties. ${ }^{69}$ This trend is anticipated since in Slovenia the degree of protection of the rights of the parties has been traditionally high, while the need for more effective and flexible administrative procedure has emerged later mostly due to economic development. ${ }^{70}$

One of the major innovations of GAPA in the field of modernisation from the technical point of view was the legal regulation of electronic communication in administrative procedure in 2004 . This enabled the conduct of administrative procedure by electronic means, which applies to all its phases, from submitting applications, to issuing and serving decisions. This arrangement largely addressed the field of electronic submission of applications, issuing of publications and the course of administrative procedures via the internet, and personal electronic serving, which enables the issuing of electronic decisions. ${ }^{71}$ To make e-communication work in practice the "E-government - State Portal" was launched in 2001. It was designed as a public portal of the Republic of Slovenia for citizens and an electronic entry point for various services provided by state bodies or public administration bodies. The portal is administered by the Ministry of Public Administration. Its basic purpose is to provide online administrative services to citizens and thus provide an additional, electronic path for the provision of services in addition to the standard ones. ${ }^{72}$ Although Slovenia has rich and relatively long-standing experience in introducing electronic commerce into public administration effective informatics, increased use of e-services and interoperability of information solutions are defined as future goals in the Slovenian Public Administration Development Strategy 2015-2020. ${ }^{73}$

68 E.g. determination of the moment of beginning the procedure and the procedural conditions for its beginning, reduction of legal remedies, reducing deadlines for legal remedies, exchange of information from official records by administrative bodies.

69 E.g. providing the right of access to the file and access to public information.

70 On this see: P. Kovač, Modernizing Administrative Procedural..., p. 51-54.

71 More on this amendment see: T. Jerovšek, Procesno postopanje državne uprave v luči obravnavanih sprememb zakona o splošnem upravnem postopku, [in:] X. dnevi javnega prava, Portorož 2011, p. 239 and T. Ivanc, Posebnosti novele Zakona o splošnem upravnem postopku, "Lex localis" 2008, vol. 6, no. 1, p. 73.

72 About Egovernment, available at: https://e-uprava.gov.si/en/o-e-upravi/o-eupravi-en.html (accessed: 18.01.2020).

73 More on this see: Public Administration Development Strategy 2015-2020, http://nio.gov.si/ nio/asset/strategija+razvoja+javne+uprave+2015+2020 (accessed: 18.01.2020), p. 133-139. 
Despite the fact that GAPA has never been the model act, which would feature constant updates and develop in lines with the current modernisation trends, it can be considered as entirely appropriate given the present time and place. Considering its up-to-dateness, GAPA does not in any way lag behind other general procedural laws in Slovenia.

\section{Codification of administrative procedure and decodifying trends}

Many sector-specific acts in Slovenia (Tax Procedure Act, Inspection Act, Spatial Planning Act, Building Act etc.) govern specific administrative procedures, which are adapted to individual administrative areas. In such cases GAPA subsidiary applies. A similar trend can be observed in procedures of judicial review of administration, since many acts govern certain rules of administrative dispute differently compared to ADA (Banking Act, Insurance Act, Auditing etc.). The abundance of special regulatory regimes in the field of administrative procedure and administrative dispute, usually imposed by specific characteristics of some administrative areas and maximum efficiency requirements, may result in lack of transparency, but in principle such arrangement is not contrary to Slovenian Constitution. Usually unconstitutionality is attributed to those specific administrative procedure regulations, which deviate from the basic principles of GAPA and at the same time interfere with constitutional procedural guarantees or constitutionally guaranteed rights. $^{74}$

\section{Codification of administrative procedure and practice}

GAPA comprehensively regulates the administrative procedure without any unconstitutional legal gaps or other deficiencies that would make its application substantially difficult, therefore it can be considered as entirely appropriate in terms of its content. In practice there are no difficulties originating from an inadequate or

74 For instance, see the decision of the Constitutional Court of the Republic of Slovenia no. U-I$252 / 00$ of 8 October 2003, the decision of the Constitutional Court of the Republic of Slovenia no. U-I-118/09 of 10 June 2010. 
insufficient regulatory framework in GAPA. Instead, violations are attributable to non-compliance or misapplication of GAPA rules. Most often, GAPA is violated due to non-observance of indicative time-limits for decisions in administrative procedures and due to non-compliance with rules on the conduct with an application lodged..$^{75}$ As indicated by case law, administrative procedures very commonly include violations of the right to be heard and the right to give reasons for decision. ${ }^{76}$ However, there are several options for ensuring effective legal protection in cases where violations occur (appeal procedure, administrative dispute, constitutional complaint). Moreover, a measure that could contribute to reducing the above-mentioned violations is the establishment of compulsory training of public employees who conduct administrative procedure and make decisions. ${ }^{77}$

GAPA does not regulate certain institutions included in comparable foreign regulation of the administrative procedure, e.g. administrative contracts, rules on mediation. Currently, the lack of these provisions does not cause such difficulties in practice as to direct legislative activities towards their express regulation in GAPA.

\section{Successes and failures - what has not been achieved?}

By providing basic procedural guarantees and specific regulation of process rules, GAPA enables a fair and democratic conduct of administrative procedure. The parties are guaranteed impartiality and (at least on normative level) a timely processing of applications, the right to be heard, the right to representation, the right to assistance, the right of access to the file, the right to give reasons for decision, and the right to effective remedy. All in all, GAPA ensures a high degree of protection of the rights of the parties. In the field of administrative procedure, a lot has

75 On this see: Poročilo o delu Inšpektorata za javni sektor, https://www.gov.si/assets/organiv-sestavi/IJS/Porocila-o-delu/Porocila-o-delu-IJS/Porocilo_o_delu_IJS_2019.pdf (assessed: 12.09.2020), pp. 14. To avoid non-compliance with deadlines the Public Administration Development Strategy 2015-2020 suggests to regularly monitor the methods and deadlines for resolving the cases. It proposes establishment of an IT tool, including a data warehouse, which will be an official source for statistical reporting, operation monitoring and management. More on this see: Public Administration Development Strategy...

76 Report of the Administrative court no. Su 17/2019 of 18 February 2019 shows that in 2018 the action in administrative dispute was granted in $29.5 \%$ cases of which $35.9 \%$ due to violations of procedural rules.

77 On this also Slovenian Human Rights Ombudsman in annual report, http://www.varuh-rs.si/ publications-documents-statements/annual-reports/?L=6 (accessed: 18.01.2020), p. 250. 
been achieved also through other methods (e-communication, e-govt, etc.). Moreover, the adoption of ADA in 2006 has proven to be a success, since the burden of administrative justice has been lowered. ${ }^{78}$

However, some argue that the regulation in GAPA is over-formalized and detailed, and that it overprotects the rights of parties in relation to the efficiency of administrative procedures or the protection of the public interest. Furthermore, more progressive approaches, such as alternative dispute resolution methods in administrative matters, are said to be underdeveloped in Slovenia. ${ }^{79}$

It seems that the Public Administration Development Strategy 2015-2020 has decided to follow these arguments. In this context, the Strategy says that one of the goals for the modernisation of administrative procedural law is the establishment of a modern and efficient system of administrative procedural protection. New system should, among others, ensure the possibility of participatory formation of administrative relations and introduce administrative contracts. To achieve this goal a new GAPA (shorter, more transparent, enabling participatory formation of administrative relations and more efficient management of administrative procedures) is suggested to be passed. ${ }^{80}$ In view of that, it is important to stress that the stated proposals are at this point merely a part of the government strategy, and that they have not yet been coordinated with either experts or the general public, therefore a broad consensus has not yet been reached with regard to them.

\section{General conclusions and comments on the prospects for the development of the law on administrative procedure}

Despite the fact that GAPA has not changed substantially in the last twenty years, it can be considered as entirely appropriate given the present time and place. Its identifying characteristic is the high degree of protection of the rights of the parties, which in turn in some cases contributes to reduced efficiency of the administrative procedure. ${ }^{81}$ In practice, the main issue in GAPA application is the failure to observe deadlines in issuing administrative procedure decisions. To tackle this,

78 E. Kerševan, The Principle of Effective..., p. 280.

79 P. Kovač, The Requirements and Limits..., pp. 448-449.

80 Public Administration Development Strategy..., pp. 98-102.

81 In GAPA all fundamental principles of fair procedure are guaranteed: in all cases all parties to procedure have the right to be heard and the right to access to all relevant documents as its part thereof, the right to appeal a decision issued at the first instance and the right to legal assistance. On this see: E. Kerševan, The Principle of Effective..., p. 269. 
efficiency in the cooperation between various administrative authorities should be increased, regular expert trainings for officials should be implemented, and certain changes in the workforce should be introduced.

GAPA certainly has a potential for further development. Changes, directed at a greater efficiency and flexibility of administrative procedure will undoubtedly be welcomed. On the other hand, it is not expected that in the future, the administrative procedure arrangement in Slovenia will deviate from the current design and the pertaining tradition based on Austrian law. For a very long time, the administrative procedure arrangement in Slovenia has been in a certain sense nearing civil procedure. Changes that would alter this ratio and at the same time lower the degree of protection of rights in procedure, probably would not be well-received.

\section{Stowenia}

Ogólne postępowanie administracyjne w Słowenii można śmiało uznać za dziedzictwo koncepcji i rozwiązań przyjętych niegdyś w Austrii, a następnie w Jugosławii. Deklarując niepodległość w 1991 r., recypowano tam ustawę jugosłowiańską regulującą ogólne postępowanie administracyjne. Jej słoweński odpowiednik z 1999 r. (GAPA) powielił większość konstrukcji ukształtowanych przez ten akt. W ciągu 20 lat nie dokonano żadnych istotnych zmian GAPA, zarówno co do zakresu unormowania ustawy, jak i jej treści. Jak dotąd była ona znowelizowana ośmiokrotnie.

W Słowenii stopień ochrony praw stron jest tradycyjnie wysoki. Panuje jednak przekonanie, że konieczna jest bardziej efektywna i elastyczna procedura administracyjna. Myśl ta pojawiła się z biegiem czasu, wraz z rozwojem gospodarczym. W związku z tym większość poprawek do GAPA koncentrowała się na usprawnieniu procesu podejmowania decyzji oraz na zmniejszeniu obciążeń administracji. Tylko nieliczne z nich miały na celu wzmocnienie uprawnień proceduralnych stron.

Zapewniając podstawowe gwarancje procesowe i szczegółową organizację trybu załatwiania spraw, GAPA stoi na straży rzetelnego i demokratycznego przebiegu postępowania administracyjnego. Jak już zostało wskazane, wyróżniającą cechą GAPA jest wysoki poziom ochrony praw stron, co z kolei w niektórych przypadkach powoduje uszczerbek dla ekonomiki procesowej. Standardem kodeksowym jest bezstronność orzekania, przynajmniej w wymiarze normatywnym. Przepisy GAPA deklarują także terminowe załatwianie wniosków, a ponadto realizację praw jednostki do: wysłuchania, reprezentacji i pomocy, dostępu do akt sprawy, uzasadnienia decyzji oraz skutecznego środka zaskarżenia (ochrony).

Przepisy wspomnianej ustawy kompleksowo regulują postępowanie administracyjne, bez niekonstytucyjnych luk prawnych lub innych braków, które znacznie 
utrudniałyby ich stosowanie. W praktyce nie występują dysfunkcje wynikające z nieodpowiednich lub niewystarczających ram uregulowania zagadnień procesowych. Naruszenia prawa wynikają natomiast z nieprzestrzegania i nieprawidłowego stosowania unormowań GAPA. Najczęściej wiążą się one z niedochowaniem terminów przewidzianych dla wydania decyzji oraz nieprzestrzeganiem zasad związanych ze złożeniem wniosku. Analiza orzecznictwa sądowego dowodzi, że w postępowaniu administracyjnym często nie respektuje się praw strony do bycia wysłuchanym i do poznania uzasadnienia zapadłego rozstrzygnięcia. Istnieje jednak kilka opcji zapewnienia skutecznej ochrony prawnej w takich przypadkach (zwykłe i nadzwyczajne środki zaskarżenia, skarga do sądu administracyjnego, skarga konstytucyjna). Ogólnie rzecz biorąc, w celu zapobieżenia zjawisku nieprzestrzegania terminów załatwienia sprawy postuluje się wzmocnienie współpracy między różnymi organami administracyjnymi, prowadzenie regularnych szkoleń eksperckich dla urzędników oraz zmiany w polityce kadrowej.

Autorka sygnalizuje, że postanowienia GAPA nie obejmują niektórych instytucji znanych przepisom obcego prawa o postępowaniu administracyjnym, takich jak umowy administracyjne czy mediacja. Obecnie brak regulacji w tym przedmiocie nie stwarza w praktyce trudności na taką skalę, która uzasadniałaby potrzebę interwencji ustawodawcy. Jedną ze znaczących innowacji GAPA było unormowanie w 2004 r. kwestii komunikacji elektronicznej w postępowaniu. Zabieg ten umożliwił prowadzenie postępowania - dzięki porozumiewaniu się na odległość - we wszystkich jego fazach, od momentu złożenia wniosku, aż do wydania i doręczenia decyzji. Pomimo tego, że w Słowenii nigdy nie zyskały aprobaty pomysły stopniowych korekt GAPA i ulegania widocznym gdzie indziej tendencjom modernizacyjnym, można uznać tę ustawę - biorąc pod uwagę obecny czas i miejsce - za całkowicie kompletną.

Przeprowadzane co pewien czas zmiany GAPA zorientowane są generalnie na usprawnienie postępowania administracyjnego i uczynienie go bardziej efektywnym. Mało prawdopodobne jest, aby ustawodawca słoweński zdecydował się na odejście od obecnego modelu postępowania i zerwanie $z$ austriacką tradycją kodyfikacyjną. Przez bardzo długi czas postępowanie administracyjne w Słowenii wykazywało wiele podobieństw do procedury cywilnej. Zmiany, które zniosłyby tę zależność, a jednocześnie obniżyły stopień ochrony procesowej jednostki, nie spotkałyby się zapewne $\mathrm{z}$ akceptacją.

(tłum. Monika Kmieciak)

Bruna Žuber, Dr, Ph.D., Assistant Professor at the Faculty of Law, University of Ljubljana and Senior Judicial Advisor at the Supreme Court of the Republic of Slovenia. Author of numerous scientific publications in the field of administrative procedural law and constitutional procedural law. Since 2018, member of national expert group for the reform of direct democracy legislation on behalf of 
the Slovenian government and legal expert for preparation of national legislation. Project leader of several national research projects concerning administrative procedural law and member of international research projects. In 2019 the recipient of four distinguished awards for professional work and scientific achievements. 


\title{
Chapter XII
}

\section{The Legacy of the Austrian Codification Thought - an European Perspective}

\author{
Agnieszka Krawczyk, Ph.D., Professor of University of Łódź \\ Head of the Section of Comparative Administrative Procedure, Department of Adminis- \\ trative Procedure, a judge of the Voivodship Administrative Court in Warsaw \\ University of Łódź, Faculty of Law and Administration \\ akrawczyk@wpia.uni.lodz.pl
}

iD https://orcid.org/0000-0003-3747-2493

\section{Sources of law of the administrative procedure}

The idea that activities of state bodies need to be covered by a uniform statutory regulation and that rights should be granted to the subjects of administrative law, which emerged in the "Old Austria", has been paving the way there since the second half of the 19th century. The typical features of the lawmaking practice in that period were, firstly, the ad-hoc, time-specific and need-based supplementation of substantive legislation with more or less detailed procedural provisions and, secondly, the creation of provisional departmental official instructions. Combined, those two factors led to the development of a varied set of principles of the administrative procedure, which has had an increasingly adverse effect on practice. The negative effects of this development could be eliminated only after the collapse of the Habsburg Monarchy, despite the demands for a common framework of the administrative procedure, expressed more and more clearly over time, and formal initiatives taken to achieve this goal. ${ }^{1}$ At the time, the only counterbalance to procedural particularism was the jurisprudence of the Administrative Court in Vienna, which had been in operation since October 1876 and whose long-standing

1 These initiatives include a memorandum on the reform of internal administration (Studien über die Reform der inneren Verwaltung), commissioned by Prime Minister E. von Körber and published in 1904, as well as a draft ministerial decree with the rules of procedure before political authorities, submitted to the Commission for the Reform of Administrative Law chaired by Dr E. Freiherrn von Schwartzenau, a body created in 1911 (see L.K. Adamovich, B.-K. Funk, Allgemeines Verwaltungsrecht, Wien 1987, p. 372). 
work served as a basis for legal scholars who came to develop a system of administrative procedure. ${ }^{2}$ This system provided the foundations for a number of laws comprising the final outcome of the codification efforts, and specifically, the Act of 21 July 1925 on the general administrative procedure (Allgemeines Verwaltungsverfahrensgesetz, AVG).

Austria's widely recognised pioneering achievement quickly found followers in other states of the former Habsburg Monarchy, which - owing to pre-codification experiences - have firmly embraced the idea of addressing the need for a uniform and nationwide legal framework of the administrative procedure. With the newly emerging European codifications (Polish, Czechoslovakian and Yugoslavian, and later - Hungarian), the "legal heritage of the Old Austria" has permeated the legal systems of states of the former Monarchy. This allowed the community known as the "Austrian legal family" (österreichische Reschtsfamilie) to survive, albeit on different terms. ${ }^{3}$

The tradition of uniform codification of the administrative procedure was upheld by the countries of the former Habsburg Monarchy also after World War II. Although those countries mostly adopted new laws on administrative procedure, the new legislation employed solutions introduced in the inter-war period. These laws have survived the period of the so-called "people's democracy", during which they were actually regarded as "enclaves of the rule of law" in the midst of the socialist legal system, mainly due to the ideological neutrality of the subject-matter of the administrative procedure. ${ }^{4}$ They remained in force, more or less unaltered, in most of the Habsburg succession states at least until the end of the 20 th century, when (and if) they were replaced by new laws on the administrative procedure.

The existence of a central codification of the administrative procedure is a unique feature common to the states of the former Habsburg Monarchy and an important part of the legacy of the "Old Austria", which has become a permanent element of the European legal tradition. In terms of content, the codification has set a standard of legal protection which is instrumental to the lawful operation of administrative proceedings today and, at the same time, provides a stable basis for the further evolution of the administrative procedure. As demonstrated by the experiences of the countries that decided to adopt new codifications, a complete departure from the classic institutions of procedural law is currently

2 See a famous work of F. Tezner, Das österreichische Administrativverfahren, Wien 1922, a second edition 1925.

3 H. Slapnicka, Österreichs Recht außerhalb Österreichs. Der Untergang des österreichischen Rechtsraum, Wien 1973, p. 78.

4 B. Wieser, Das Verwaltungsverfahren im Vergleich, [in:] Vergleichendes Verwaltungsrecht in Ostmitteleuropa, Red. B. Wieser, A. Stolz, Wien 2004, p. 369; idem, Das Verwaltungsverfahren im Vergleich, [in:] Vergleichendes Verwaltungsrecht in Südosteuropa, Red. B. Wieser, A. Stol, Wien 2016, p. 375. 
out of the question. Indeed, the re-codification attempts rather aim at finding solutions for working out "a compromise between the need to radically reorganise the administrative procedure and the imperative of preserving own national legal tradition". 5

\section{General and special administrative procedure}

The Austrian codification process was marked by the desire to apply a possibly uniform procedural framework to the largest possible group of administrative bodies. At the same time, it was realised that the codification of the administrative procedure can never be complete and that its purpose was, while guaranteeing the necessary degree of procedural uniformity, to give the legislator freedom to regulate certain specific issues. The required equilibrium was achieved by resorting to a typical clause of Austrian legislation, namely the expression "unless special provisions specify otherwise". This expression operated as a reservation of priority for the application of special provisions in certain cases.

This method has been used in all codifications of the Habsburg succession states. In those jurisdictions, exceptions to the code rules have been introduced mainly by incorporating procedural provisions into acts of substantive law. As a result, the current state of the administrative procedure in the countries of Austrian legal tradition is generally described as a "combination of general and special regulations". ${ }^{6}$ Special regulations apply not only to their basic subject-matter but also to the procedural aspects of the performance of public administration's responsibilities in specific legal areas (such as building law, customs law, etc.). These regulations implement rules different from those laid down in the main enactment on the administrative procedure, which then applies exclusively on a subsidiary basis.

The ensuing and gradually expanding procedural dualism has led to the consolidation of the division of administrative procedure into "general" and "special". The consequences of this division have quickly become apparent, inevitably leading to the dispersion of the procedural rules, and eventually, the diminishing importance of the codifications. The Habsburg succession states have so far been unable to eliminate the negative effects of this phenomenon - neither by amendments nor by re-codification. Moreover, excessive deviations from the general rules were not prevented by the introduction of legal restrictions on the laying down of special

5 F. Staničić, Das Verwaltungsverfahren in Kroatien, [in:] Vergleichendes Verwaltungsrecht in Südosteuropa, p. 234.

6 J. Machajová, Das Verwaltungsverfahren in der Slowakei, [in:] Vergleichendes Verwaltungsrecht in Südosteuropa, p. 290. 
provisions. In Austria, such restrictions are stipulated in Article 11 (2) of the Constitution (Bundes-Verfassungsgesetz, B-VG), ${ }^{7}$ which allows exceptions to the rules laid down in the AVG only where "necessary to regulate the subject-matter of the proceedings". Despite the fact that the Austrian Constitutional Court has ruled that such exemptions are allowed only if they are "indispensable", the excessive dispersion of procedural rules in substantive laws has not been avoided. ${ }^{8}$ The desired level of unification of the administrative procedure has also not been achieved in the legal systems that have chosen the re-codification option. In Croatia, the above goal has not been achieved despite the rule introduced in the Croatian law on the administrative procedure, according to which the law should be applied in all administrative matters and that special provisions may only be applied if such application is necessary and does not contradict the law's aims and purpose. The above rule has itself created an array of admissibility problems, exacerbating legal uncertainty and the consequent increase in the impact of administrative and judicial means of challenge. ${ }^{9}$

These observations support the belief that even the most restrictive limitations on the admissibility of derogations from general rules cannot prevent the expansion of special rules. The Hungarian lawmakers seem to acknowledge this situation: in the 2016 Code of General Administrative Procedure they introduced a list of areas exempted from the Code's scope of application (e.g. tax law, customs law, electoral law) while resolving that any exemptions in the areas outside the list are allowed only where the Code itself so provides. At the same time, Hungary allowed for the adoption of supplementary regulations compatible with the Code by means of regulations issued by bodies of the executive (except for ministers). This reasonable approach was aimed at establishing communication between the Code rules and the special provisions which must fall within the framework set by the Code. By excluding the possibility of adopting separate ad hoc provisions in a manner that would be detached from the Code principles and contrary to its provisions, the Hungarian legislature has taken an important step towards the unification of the administrative procedure.

The above experiences show that the rationale for maintaining the division into general and special administrative law is arguably becoming more and more questionable. In defining the boundaries of the administrative procedure, one cannot ignore the elements of the codification such as relevant applicability exclusions or references and provisos concerning the applicability of separate provisions. Despite adding to the complexity of the system of administrative procedure, these elements are the requisite component of a complete legal framework of the rules of administrative procedure.

7 Constitution of the Republic of Austria of 1 January 1930, BGBI no. 1/1930, as amended.

8 J. Hengstschläger, Verwaltungsverfahrensrecht, Wien 2009, pp. 35-36.

9 F. Staničić, Das Verwaltungsverfahren in Kroatien..., p. 237. 


\section{The party to administrative proceedings}

The notion of a party to administrative proceedings (Partei) is a key element of the Austrian legal tradition. As set out in $\$ 8$ AVG, the criterion distinguishing a party from other participants in the proceedings is the former's participation in the proceedings on the basis of a legal claim (Rechtsanspruch) or a legal interest (rechtliches Interesse). Despite the distinction made in the provision, both the legal claim and the legal interest are clearly forms of the exercise of one's subjective right. The difference between the two lies in the fact that the former means a demand, justiciable under substantive law, for a certain conduct from a public authority, while the latter is a request for enabling the claimant to proceed with their own case, which does not confer the right to demand a specific conduct from a public authority. The legal claim and interest are both founded on substantive law, as the AVG only provides a framework whose content is always determined by substantive law. ${ }^{10}$

The substantive concept of the party was adopted in all codifications of the Habsburg succession states, although these codifications have not used the verbatim wording of the AVG. They defined the party without resorting to the typical Austrian notion of "legal claim", but only establishing the condition of the existence of a "legal interest" or a "legally protected interest" and sometimes supplementing it with additional provisos (including references to a right or duty). A typical example of this approach is the Polish Code of Administrative Procedure, which defines a "party" as anyone whose "legal interest or duty" is affected by the proceedings or who demands action of an authority because of their "legal interest or duty". An equivalent term is used by the Slovak law, which makes the status of a party in administrative proceedings conditional on the existence of the party's "rights, legally protected interests or obligations". A similar approach has been taken in the Slovenian, Croatian and Serbian law and the Hungarian Code of 2016. Despite the adoption of the Austrian concept of the party, not all codifications of the countries of the Austrian tradition use the actual term. In some of these enactments, e.g. the Czech law, the term "party" was abandoned in favour of "participant in the proceedings", which was explained by the need to avoid in administrative proceedings the use of a nomenclature typical of litigation. ${ }^{11}$

The overwhelming majority of the Habsburg succession states also adopted the traditional Austrian categorisation of parties to proceedings. There, parties are divided into different categories based on the manner and intensity of the protection they receive: there is the principal party (Hauptpartei), the subsidiary party

10 L.K. Adamovich, B.-K. Funk, Allgemeines..., p. 376.

11 D. Hendrych, Das Verwaltungsverfahren in Tschechien, [in:] Vergleichendes Verwaltungsrecht in Ostmitteleuropa, p. 265. 
(Nebenpartei), the opposing party (Gegenpartei) and the entities granted the status of the party under substantive law, or "legal parties" (Legalpartei). Moreover, active and passive parties (aktive und passive Partei) are distinguished based on how the proceedings are initiated.

The concept of a "legal party" is explicitly referred to in the Czech law and the Hungarian Code of 2016. The latter provides that in certain cases the status of a party may be granted by a law or government decree. The notion of principal and subsidiary party (or, alternatively, that of "intervener"), is used in the Croatian, Slovenian, Serbian and Macedonian codifications. Under these laws, the subsidiary party, or intervener, is a person who is involved in proceedings concerning another person (an active or passive party) because of the need to protect their own rights or a legal interest and is therefore also a party to those proceedings. Another element of the Austrian legal legacy, namely the concept of "interested party", is still enshrined in $\$ 8 \mathrm{AVG}$, which provides that the status of participants in the proceedings is afforded to persons who demand an action from an authority or to whom such an action relates, but have no claim or legal interest in the matter. Since interested parties have only a factual interest in the proceedings, they - similarly to their Austrian counterparts - have few procedural rights. For example, they have the right to inspect the case file (Slovenia) or the right to attend the hearing (Poland).

The notion of a party adopted in the AVG, which explicitly links the status of a participant in the proceedings to a legal interest, is a characteristic feature of the Austrian codification. It distinguishes the Austrian codification from systems in which this notion is based on formal criteria. Its main function is to consolidate the procedural norms (normökonomische Funktion) ${ }^{12}$ establishing guarantees (the right to be heard, to receive a decision, to use means of recourse or initiate extraordinary procedural avenues and to oppose inaction of an authority). The standard so established has become a permanent feature of the legal systems of the Habsburg succession states. Today, it is a permanent element of the European legal culture.

\section{The administrative decision}

"Administrative decision" (Bescheid) is a classic concept of Austrian law. It is entrenched in the constitution and has procedural origins. It was first used in the original version of the AVG and then employed in the B-VG to designate one of the forms of lawmaking. The jurisprudence and scholarship agree that the constitutional and

12 J. Hengstschläger, Verwaltungsverfahrensrecht..., p. 83. 
procedural concepts of the administrative decision are identical as both involve an act with the following characteristics: it is a form of administrative activity addressed to a specifically designated person as part of an external relationship, and issued in a formalised manner. The essence of the concept is reflected in the well-known view held by the Austrian Constitutional Court, according to which the decision is any act of a public administrative body which creates or ascertains an individual legal relationship, irrespective of whether or not such an act, formally speaking, has been issued as an administrative decision. The above rationale serves as a basis for an imperative that the legislator should establish a set of characteristics of the decision which, from the procedural point of view, will allow a decision to be qualified as such. ${ }^{13}$ Among the features that identify an administrative act as a decision, the AVG explicitly mentions the act's own designation (as a decision), its operative part and a guidance note on the available means of challenge ( $\$ \$ 58$, 59 and 61). Another element of the decision is the statement of grounds, which must include the outcome of evidentiary proceedings $(\$ 60)$.

The Austrian concept of the administrative decision and the formal requirements for its issuance have been adopted by the Habsburg succession states and they are reflected in their codifications to this day. All these codifications incorporate the assumption that the decision is a ruling administrative act of an administrative body, issued in a formalised procedure and constituting a binding resolution on the rights or duties of an individually designated entity. All of them also adopted the triad of the essential elements of a decision, namely the operative part, statement of grounds and guidance note on legal measures.

Several European codifications have recently relaxed, in a way unknown to the original Austrian legislation, some of the above requirements for the administrative decision. This was done in an attempt to streamline administrative proceedings. In Poland, such streamlining measures included the introduction of the simplified procedure into the Code of Administrative Procedure, which establishes less strict requirements concerning the statement of grounds of a decision issued in that procedure. Quite obviously, authorities were released from the obligation to draw up the statement of grounds in the event of a tacit disposition of a case. Similar solutions were already introduced in the Hungarian legal system, where "formal" decisions are distinguished from "simplified" and "de-formalised" decisions. Simplified and de-formalised decisions do not require to be accompanied by the statement of grounds if the parties have reached a settlement, or if the facts are deemed to have been established by the authority on the basis of a request from the party and data known to the authority ex officio, provided that there was no opposing party (simplified decisions), in the case of decisions issued on official 
forms, or if the matter has been settled tacitly (de-formalised decisions).${ }^{14}$ Similar regulations are included in the 2016 Code. A further simplification is provided for in the Croatian law, which allows decisions issued in minor cases to be issued by way of a note entered in the case file, provided that the issuance is based on obvious grounds and does not violate public interest or an interest of a third party. The same reasons may be invoked to waive the requirement of including the statement of grounds of a decision, also when that is issued in the general disposition procedure, in the Macedonian system.

Another element of the Austrian tradition, the division of administrative resolutions into decisions and orders (Verfahrensanordnungen), manifests itself in virtually all codifications adopted by the countries of the former Habsburg Monarchy. Differently from decisions, orders are resolutions of a purely procedural nature and usually relate to the course of proceedings. In this form, they appear in the Polish administrative procedure, as well as in the laws enacted in the Czech Republic, Hungary, Slovenia, Croatia, Serbia and Macedonia. The exception here is the Slovak codification, which employs the single catch-all term "decision" and only distinguishes a special subset of decisions equivalent to orders, "procedural decisions". The differences between decisions and orders may also relate to the manner in which they are issued and contested, which is linked to the subject-matter resolved. In contrast to decisions, which are usually made in writing, orders can be delivered verbally. As a rule, orders can be contested only in an appeal against the merits of the decision (as in Austria, under $\$ 63$ (2) AVG). An exception from this rule is provided in the Macedonian and Polish law, where orders can be contested by way of lodging a complaint on incidental issues, if the Code so stipulates.

The available options for the termination of administrative proceedings in the Habsburg succession states have somewhat evolved over the years. Initially, these options were extended by adding the measure of administrative settlement (in Poland, the Czech Republic, Slovakia and Hungary), which is a form of amicable settlement of a case between parties with conflicting interests. Over time, mostly under the influence of German solutions, the following additional options have been introduced: the administrative agreement (in Hungary, the Czech Republic, Croatia, Serbia, Slovenia and in Macedonia, where the agreement is classified as an administrative act), general acts (in the Czech Republic and Macedonia), and the tacit settlement of a case, which may take the form of a tacit consent of an authority (in Hungary, Croatia and Poland) or a tacit rejection of a request, with the effect that the decision is deemed not to have been issued (Slovenia).

These inspirations, justified by the need to increase the effectiveness of the administrative procedure, are fully understandable. They cannot be found in the Austrian system, where the possibility of introducing any measures to terminate

14 I. Vadál, Das Verwaltungsverfahren in Ungarn, [in:] Vergleichendes Verwaltungsrecht in Ostmitteleuropa, pp. 352-353. 
the proceedings other than the decision is excluded by art. $130 \mathrm{~B}-\mathrm{VG}$, which sets out the exhaustive list of forms in which public administration operates. Thus the administrative procedure in the Habsburg succession states is becoming increasingly strongly influenced by measures adopted in other, mainly Germanic, jurisdictions. However, the use of these measures in domestic legal systems does not undermine the 19th-century Austrian concept of administrative decision, which is invariably viewed as the primary form of dealing with administrative matters.

\section{Means of legal protection in administrative procedure}

A characteristic feature of the Austrian codification is the concept of legal protection (Rechtsschutz), which aims, on the one hand, to safeguard the subjective rights of parties and, on the other, to ensure that decisions made by public administration are consistent with the objective legal order. This concept is reflected in the provisions of Part IV of the AVG, which sets out a list of measures designed to provide legal protection: appeal on the merits (Berufung), ${ }^{15}$ ex officio repeal or modification of a decision (Abänderung und Behebung von Amts wegen), declaration of invalidity (Nichtigkeit), and reopening of the proceedings (Wiederaufnahme der Verfahrens). A remedy against administrative inaction (Devolutionsantrag) has been added to this list.

Among the means of legal protection (Rechtsmittel) envisaged in the administrative procedure, a distinction is thus made between means of challenge (Rechtsbehelf), which award a party the claim for having a decision issued, and the supervisory measures (Aufsichtsmittel), which are imposed by an authority acting ex officio and may not be subject to a party's claim. The legal means in the strict sense, understood as means to challenge a decision unfavourable to a party, are divided into the following categories: ordinary and extraordinary, the latter may be brought only under certain conditions and for specific reasons; devolutive, transferring the case to a hierarchically higher authority and non-devolutive (remonstrative), resulting in the case being decided by the authority which has issued the original decision; suspensive, staying the execution of the decision, and non-suspensive, the lodging of which does not exclude the execution of the decision,

15 In the original version of the AVG, the notion of "appeal on the merits" included recourse and appeal on incidental issues (Rekurs, Beschwerde), as well as presentation (Vorstellung) - see $\S 63$ AVG. 
as well as cassatorial, aiming to repeal the decision, and reformatory, brought to replace the contested decision with another one issued in its place. ${ }^{16}$

Appeal on the merits was the primary means of protecting a party's subjective rights provided for in the AVG (\$ $\$ 63-67)$. The appeal was an ordinary, devolutive, suspensive and reformatory means of challenge. Its purpose was to review the decision (Überprüfung) in administrative appellate proceedings (Instanzenzug); the scope of the review has been left to be determined in special provisions. This measure was conceived as a measure subject to few formal requirements; the appellant merely had to identify the contested decision and give the reasons for their request. The time limit for lodging the appeal was 2 weeks from the date of delivery or notice of the decision. As soon as the decision was delivered or notified, a party could also waive their right to bring the appeal. It was possible to conduct evidentiary proceedings as part of appellate proceedings, albeit only on a subsidiary basis, also at the request of a party who was not subject to the prohibition of "novelty" (kein Neuerungsverbot). If the appeal was admitted, the appellate authority was obliged to issue a decision. As a rule, the decision amended the contested decision on the merits; only exceptionally it was a cassation decision. The appellate decision was not subject to the prohibition of the reformatio in peius.

The remaining means of challenge under the AVG are of an extraordinary nature. They include the request for the resumption of the proceedings, which may be submitted in respect of a final decision, provided that at least one of the following grounds for resumption are present: (1) the decision was issued based on false evidence, (2) new facts or evidence, previously unknown in the proceedings concluded by the contested decision through no fault of the party, which are likely to affect the outcome of the case, are brought to light, or (3) a preliminary issue has been resolved by a competent authority or court differently from the assessment adopted at the time when the decision was issued ( $\$ 69)$. The proceedings may be resumed, on the same grounds, ex officio by an authority implementing supervisory measures. In each of the above cases, the power to resume the proceedings is vested in the authority that issued the decision in the last instance.

The "pure" supervisory measures include the ex officio initiation of proceedings to repeal or amend a decision which has not conferred a right on anyone $(\$ 68(1)$ ). The competent authority in this respect is the authority that issued the decision or a superior authority. Other decisions may be repealed if it is necessary to protect the values indicated in the law, provided that acquired rights are respected ( $\$ 68(3)$ ). Furthermore, but only as part of supervisory measures, a decision may be declared invalid if: (1) the decision is issued by an authority without the competence to do so or by an improperly constituted collective body; (2) the decision, if enforced, would result in the possibility of a penalty being imposed; (3) the decision is actually unenforceable; and/or (4) the decision suffers the defect of being invalid by

16 R. Thienel, Verwaltungsverfahrensrecht, Wien 2006, pp. 242-243. 
law $(\$ 68(4))$. However, a decision cannot be declared invalid on the first ground after a period of 3 years from the date when the decision became final and unappealable.

The Austrian concept of administrative legal protection has been adopted in all states of the Habsburg succession, with no exceptions. Their codifications include a system of diverse legal measures geared towards the protection of both individual interests (means of challenge) and public interest (supervisory measures). The means of challenge consist of both ordinary legal measures, which a party may bring against a non-final decision, and extraordinary measures, aimed at challenging a final decision on the grounds laid down in the law.

The ordinary legal measures include the appeal on the merits. It may be lodged in administrative appellate proceedings. In all countries of the former Habsburg Monarchy, appellate proceedings comprise only two instances. The exceptions to the above rule vary in scope. The most far-reaching exception was introduced in Austria itself. In that country, a reform of the administrative courts abolished, with effect from 1 January 2014, administrative appellate proceedings, which were maintained only in municipal cases. No other post-Habsburg state has yet decided to follow Austria's footsteps, although they increasingly more often consider a judicial review to be a sufficient measure of legal protection. This approach is apparent in those systems where it is impossible to appeal against first instance decisions of certain bodies, mainly because those bodies (e.g. ministers, local government) do not have a superior authority. For example, both Hungarian codifications provide that the repeal or amendment of such decisions can be pursued directly through the courts by their recipients. In Slovenia, concerns about the constitutionality of such solutions have been resolved by the courts, which ruled that they were admissible, provided that an effective means of judicial review is guaranteed to the party in lieu of an appeal. ${ }^{17}$ In other jurisdictions, such as the Czech Republic or Slovakia, the two-instance principle was upheld in such cases by way of replacing the appeal on merits with an equivalent measure, namely the request for a re-examination of the case, which may be submitted to the same authority or the head of the authority that issued the contested decision. An intermediate solution has recently been adopted in Poland, where a party may either request a re-examination of the case in administrative proceedings, or immediately seek judicial review, bypassing the re-examination procedure.

Apart from the above exceptions, the appeal on the merits available in the legal systems of the Habsburg succession states has retained its traditional nature. A party may lodge the appeal against the merits of any decision to review the decision's legality and - in some more recent codifications (Serbia, Macedonia) - also its purposefulness. The latter codifications extend the right of appeal to new forms

17 E. Kerševan, Das Verwaltungsverfahren in Slowenien, [in:] Vergleichendes Verwaltungsrecht in Südosteuropa, p. 219. 
of case resolution, such as tacit decisions (Serbia, Macedonia), and where such an extension is impossible, supplement the catalogue of ordinary legal measures with new instruments. These include the opposition provided for in the Croatian law, which may be filed, among other things, in connection with the conclusion of an administrative agreement, including as a remedy against the authority's failure to perform the agreement. What has not been changed is the principle that the appeal on the merits is a suspensive measure, and the authority which issued the decision may decide to enforce it immediately on the grounds specified in a law.

In nearly all Habsburg succession states, the appeal is de-formalised (the exception here is the Hungarian law of 2016, which requires that the appeal be reasoned). The time limit for lodging the appeal is usually 15 days from the date of delivery or notice of the decision. Within this period a party may waive the appeal (as per the Czech, Slovak, Hungarian and Polish laws) and the waiver is irrevocable. The same classic principles apply to the course of appellate proceedings, with the first instance authority having the power to self-correct the issued decision. At the same time, the first instance authority is obliged to transmit the appeal to a superior authority only if the former finds that there are no grounds to allow the appeal. The remit of the first instance authority varies at this stage, sometimes the authority is awarded narrow powers, limited to the repeal or amendment of the contested decision in the situation where the appeal should be admitted in its entirety and is submitted by all parties (Poland, the Czech Republic, Slovakia, Hungary), whereas sometimes the first instance authority is given an extensive remit, which includes the obligation to conduct supplementary evidentiary proceedings with the possibility of repealing or amending the contested decision (Slovenia, Serbia, Macedonia) and dismissing the appeal (Croatia).

The appellate authority examines the case in its entirety and, to that end, may conduct a supplementary inquiry, which covers any new facts and evidence put forward by a party. An exception to that rule is provided for in the Czech and Hungarian codifications, which allow for "novelties" in appellate proceedings only if a party was not aware of them in the first instance proceedings or could not invoke them for reasons beyond the party's control. On the other hand, an exception to the principle of conducting supplementary evidentiary proceedings was introduced in 2017 by the Polish legislator, who resolved that the appellate authority may conduct such proceedings "to an extent necessary" and with the consent of all parties.

The classic Austrian concept is also reflected in the decision making principles applying to the appellate authority. If the appellate authority does not accept the appeal, it upholds the decision of the first instance authority (dismisses the appeal). On the other hand, if the authority finds the appeal well-founded, it is obliged to resolve the matter on the merits. The appellate authority will only issue a cassation decision if it finds that evidentiary proceedings need to be repeated. Certain laws have more or less restricted the conditions for issuing a cassation decision. 
Some stipulate, for example, that this may be done when the removal of defects in the proceedings will be more time- and cost-effective in the proceedings before the first instance authority (Slovenia), while others preclude the issuance of a cassation decision whenever the appellate authority has conducted evidentiary proceedings to the extent necessary to resolve the case (Poland).

All countries of the former Habsburg Monarchy (except Hungary) offer an extraordinary protection measure in the form of the request for the resumption of the proceedings. This measure has been designed in a traditional way, as a measure against a final decision exercisable if statutory grounds exist. Each jurisdiction sets out a broader or narrower list of these grounds, but they are all related to serious defects of the proceedings concluded by the contested decision. Importantly, a party may submit a request for the resumption of the proceedings only within a time limit set by a law, usually 30 days or one month of becoming aware of the circumstances justifying the resumption of the proceedings (the subjective time limit). Longer time limits are provided for authorities which may resume proceedings ex officio in the exercise of its supervisory powers (the objective time limit). In Croatia, an authority may resume proceedings, in principle, no later than 3 years after the delivery of the decision. In the Czech Republic and Slovakia, the same time limit runs from the date when the decision became final and unappealable. Significantly longer resumption time limits are provided for in the Polish codification ( 5 and 10 years, depending on the grounds for resumption). As a rule, the power to resume proceedings is vested in the authority that issued the decision. The resumption of proceedings may result in the existing decision being left in circulation or led to the issuance of a new decision invalidating the previous one. A party may contest a decision issued in this way by resorting to the ordinary legal measure.

All codifications of the Habsburg succession states also provide for extraordinary legal measures of a supervisory nature, which is the most evident departure from the original Austrian concept. In some countries, certain features typical of the AVG have not been employed at all. Examples of the above include the declaration of invalidity of a decision (non-existent in Slovakia, the Czech Republic introduced it only in the 2004 codification) or the resumption of proceedings (Hungary). In other jurisdictions, they have been modified through "splitting" it into many separate measures such as the repealing, amendment and declaration of a decision's invalidity (Macedonia); the repealing and voiding of a decision; the extraordinary voiding of a decision accompanied by a declaration of its invalidity (Slovenia, Serbia); the repealing and amendment of a decision with the consent of a party (Serbia, Poland). Some more recent codifications introduce a reduced number of extraordinary avenues, which are either aggregated or made the subject of temporal limitations related to their activation. This rationale was followed by the drafters of the Croatian law, which sets out only two extraordinary avenues (apart from the resumption of proceedings), namely the declaration of invalidity of a decision and the invalidation or 
repealing of a decision. The latter measure is used to either repeal or void a decision, depending on whether or not the decision was lawful, in consideration of the principle of protection of acquired rights. This avenue differs from the "simple" declaration of invalidity which has the retroactive (ex tunc) effect and may be used only to nullify decisions affected by severe defects, such as decisions issued in matters falling within the exclusive jurisdiction of the court or matters that should not have been addressed in administrative proceedings; decisions that are unenforceable; or decisions whose enforcement would result in a punishable offence. A decision to invalidate a decision may be issued by the authority which issued the decision or a superior authority, either at the request of a party or ex officio. ${ }^{18}$ A solution differing from the classic approach to extraordinary avenues has also been included in the Hungarian Code of 2016. The ex officio legal protection measures laid down in the Code include (apart from a prosecutor's request) only the avenue of amending and revoking a decision, which is done through the exercise of the substantive jurisdiction by the issuing authority or under the rubric of supervisory proceedings. These measures are exercisable within a short time limit laid down by the law, provided that no other avenue has been pursued to review the defective decision, and subject to the obligation to protect acquired rights. The law also sets out the grounds for the invalidity of a decision, which must exist so that a decision may be declared invalid or revoked. The above measures constitute an amalgamation of the classic grounds for invalidity (a decision being issued by an authority without the competence to do so, or a decision whose enforcement would result in a punishable offence) and for the resumption of proceedings (other parties should have been able to participate in the proceedings).

The difficult problem of the conflict between the need to ensure the stability of a decision and to guarantee its legality has led to a considerable variety in the extraordinary avenues for decision review. Although they all follow the traditional approach, continuing to form a basis for a post facto review of a final decision on the grounds set out in a law, this is the only common feature they have. This reinforces the view that the Austrian concept of administrative legal protection is no longer fully in line with contemporary practice.

The exceptions to the typical solutions used in the AVG also apply to measures designed to protect against the inaction of public administration. None of the countries of the former Habsburg Monarchy decided to adopt the typical Austrian formula for the codification of the devolution request. Under the AVG, a party was entitled to submit this request to a superior authority if the first instance authority failed to issue a decision within a maximum period of 6 months from the making of a demand. The submission of a devolution request resulted in the jurisdiction to examine the case being transferred to the superior authority which resolved the case as the first instance authority ( $\$ 73$ AVG). In Austria, this concept has been

18 F. Staničić, Das Verwaltungsverfahren in Kroatien..., pp. 234 and 259. 
modified in connection with a reform of the administrative courts. As of 1 January 2014, a devolution request is available only in municipal cases, while in other cases the parties may resort to a measure of judicial protection, namely the request to address a failure to act by an authority (Säumnisbeschwerde). If this request is granted, the case is transferred to an administrative court to be examined and resolved on the merits. In other legal systems, protection against inaction by an authority can be sought in administrative cases by means of lodging a complaint (appeal on incidental issues, request to address a failure to act or delay in proceedings) with a superior authority. The superior authority may (but is never obliged to) take the measures necessary to remedy the state of delay (Hungary), which may include setting a time limit for the first instance authority to resolve the case (Poland) or seize the case for resolution (Croatia, Serbia, Macedonia, the Czech Republic, Slovakia). Another avenue of protection against the failure to act on the part of administrative authorities is the legal fiction (unknown in Austria) that a case is positively resolved in the event of the authority's failure to issue a decision within the legally prescribed time limit. In the countries that adopted the fiction of rejection of a request, the means of remedying the authority's inaction is the appeal on the merits against the rejection decision (Slovenia).

\section{Conclusions}

However, all those different approaches do not in any way undermine the impact of the ideas behind the Austrian codification on the development of the foundations of the European legal culture. The solutions implemented by the AVG have survived in the majority of legal systems of the Habsburg succession states. Today, being considered a well-established standard, they provide a starting point for further changes designed to meet the needs of modern times. The above conclusion is reflected in the experiences of the countries that have chosen to modify the administrative procedure. This was done by abolishing some of its classical institutions, such as administrative appellate proceedings (Austria), aggregating them (e.g. the extraordinary avenues for reviewing decisions adopted in Croatia and Hungary), or supplementing them with new solutions such as the tacit disposition of a case (Hungary, Croatia, Slovenia, Poland), the administrative agreement (Hungary, the Czech Republic, Croatia, Serbia, Slovenia, Macedonia), general acts (the Czech Republic, Macedonia), or distinct procedural avenues (Hungary, Poland). Given the above, one may reasonably argue that the direction of these changes is presently guided, on the one hand, by the need to simplify the administrative procedure and make it more effective and, on the other, by the desire to protect the rights of the individual. 
Agnieszka Krawczyk, Ph.D., Professor of University of Łódź. Head of Section of Comparative Administrative Procedure at the Department of Administrative Procedure - Faculty of Law and Administration, University of Łódź. Professor Krawczyk is a sitting judge of the Voivodship Administrative Court in Warsaw. She is author of many scholarly publications on the administrative procedure and the judicial review of administration. Her academic interests focus on the administrative procedures in German-speaking jurisdictions and countries of Central and Eastern Europe. In 2012-2016, Professor Krawczyk was a member of an expert team working on the reform of the law of administrative procedure. 


\title{
Rozdział XII
}

\section{Dziedzictwo austriackiej myśli kodyfikacyjnej z perspektywy europejskiej}

\author{
Agnieszka Krawczyk, dr hab., prof. Ut \\ Kierownik Zakładu Postępowania Administracyjnego Porównawczego w Katedrze \\ Postępowania Administracyjnego, Uniwersytet Łódzki, Wydział Prawa i Administracji \\ Sędzia Wojewódzkiego Sądu Administracyjnego w Warszawie \\ akrawczyk@wpia.uni.lodz.pl \\ iD https://orcid.org/0000-0003-3747-2493
}

\section{1. Źródła prawa o postępowaniu administracyjnym}

Zrodzona w „starej Austrii” myśl o potrzebie objęcia jednolitą regulacją ustawową działań organów państwowych i przyznaniu praw podmiotom podlegających prawu administracyjnemu torowała tam sobie drogę od drugiej połowy XIX w. Charakterystyczne dla prawodawstwa tego okresu doraźne, wynikające z potrzeby chwili, uzupełnianie unormowań materialnoprawnych mniej lub bardziej szczegółowymi przepisami procesowymi oraz tworzenie ad hoc resortowych instrukcji kancelaryjnych prowadziło do coraz bardziej dotkliwego dla praktyki zróżnicowania zasad postępowania administracyjnego. Aż do upadku Monarchii Habsburskiej negatywnych skutków tego zjawiska nie udało się wyeliminować, mimo coraz dobitniej z czasem formułowanych postulatów opracowania wspólnej regulacji postępowania administracyjnego i podejmowanych $w$ tym celu formalnych inicjatyw ${ }^{1}$. Przeciwwagę dla partykularyzmu procesowego stanowiło naówczas jedynie orzecznictwo funkcjonującego od października 1876 r. Trybunału

1 Należy do nich zaliczyć m.in. opracowane na zlecenie premiera E. von Körbera i opublikowane w 1904 r. studia na temat reformy administracji wewnętrznej (Studien über die Reform der inneren Verwaltung) oraz projekt zarządzenia ministerialnego z zasadami postępowania przed organami władzy politycznej, przedłożony utworzonej w 1911 r. Komisji ds. Reformy Prawa Administracyjnego pod przewodnictwem dra E. Freiherrna von Schwartzenau - L.K. Adamovich, B.-K. Funk, Allgemeines Verwaltungsrecht, Wien 1987, s. 372. 
Administracyjnego w Wiedniu, którego długoletnia działalność stanowiła podstawę wypracowania w nauce systemu postępowania administracyjnego ${ }^{2}$. Na tych założeniach opierały się wieńczące dzieło kodyfikacji akty z ustawą z 21 lipca $1925 \mathrm{r}$. o ogólnym postępowaniu administracyjnym (Allgemeines Verwaltungsverfahrensgesetz - AVG) na czele.

Doceniane powszechnie pionierskie osiągnięcie Austrii szybko znalazło naśladowców w państwach byłej Monarchii Habsburskiej, w których - za sprawą przedkodyfikacyjnych doświadczeń - dostatecznie już zakorzeniła się myśl o potrzebie istnienia jednolitej, wspólnej dla całego kraju regulacji prawa o postępowaniu administracyjnym. Ukształtowanie według austriackiego wzorca pierwszych europejskich kodyfikacji (polskiej, czechosłowackiej oraz jugosłowiańskiej, a także późniejszej kodyfikacji węgierskiej) sprawiło, że „dziedzictwo prawne starej Austrii" przeniknęło do porządków prawnych państw byłej monarchii, przesądzając o istnieniu w dalszym ciągu, choć na innych niż dotąd zasadach, wspólnoty określanej mianem „austriackiej rodziny prawnej” (österreichische Reschtsfamilie)3.

Tradycję jednolitej kodyfikacji postępowania administracyjnego kontynuowano w państwach byłej Monarchii Habsburskiej również po drugiej wojnie światowej. Wprawdzie w większości z nich uchwalono nowe ustawy o postępowaniu administracyjnym, to jednak wszystkie one stanowiły wyraz kontynuacji rozwiązań przyjętych w okresie międzywojennym. W takim kształcie przetrwały czasy rządów tzw. demokracji ludowej, kiedy to - głównie ze względu na neutralność ideologiczną normowanej materii - uchodziły wręcz za "praworządną wyspę" w socjalistycznym systemie prawnym ${ }^{4}$. W takim też, mniej lub bardziej zmienionym kształcie, kodyfikacje te obowiązywały w większości państw sukcesji habsburskiej przynajmniej do końca XX w., do czasu zastąpienia ich - tam, gdzie się na to zdecydowano - przez nowe ustawy o postępowaniu administracyjnym.

Istnienie centralnej kodyfikacji postępowania administracyjnego jest charakterystyczną, łączącą państwa byłej Nonarchii Habsburgów cechą i istotnym dziedzictwem „starej Austrii”, które na stałe wpisało się w europejską tradycję prawną. Pod względem treściowym wyznaczyło ono standard ochrony prawnej, bez zachowania którego trudno dziś wyobrazić sobie praworządne postępowanie administracyjne, stanowiąc jednocześnie stabilne podłoże dalszej jego ewolucji. Jak wynika z doświadczeń państw, w których zdecydowano się na rekodyfikacje, nie może być obecnie mowy o całkowitym odejściu od klasycznych instytucji prawa

2 Zob. stynne dzieło F. Teznera, Das österreichische Administrativverfahren, zweite Auflage, Wien 1925.

3 H. Slapnicka, Österreichs Recht außerhalb Österreichs. Der Untergang des österreichischen Rechtsraum, Wien 1973, s. 78.

4 B. Wieser, Das Verwaltungsverfahren im Vergleich, [w:] Vergleichendes Verwaltungsrecht in Ostmitteleuropa, Red. B. Wieser, A. Stolz, Wien 2004, s. 369; idem, Das Verwaltungsverfahren im Vergleich, [w:] Vergleichendes Verwaltungsrecht in Südosteuropa, Red. B. Wieser, A. Stolz, Wien 2016, s. 375. 
procesowego, chodzi raczej o poszukiwanie rozwiązań zorientowanych na wypracowanie „kompromisu między potrzebą radykalnej reorganizacji postępowania administracyjnego i utrzymania własnych tradycji”".

\section{Postępowanie administracyjne ogólne i szczególne}

Charakterystyczne dla austriackich poczynań kodyfikacyjnych było dążenie do objęcia możliwie jak największej liczby organów administracji możliwie najbardziej jednolitą regulacją procesową. Zdawano sobie jednocześnie sprawę, że kodyfikacja postępowania administracyjnego nie może być kodyfikacją zupełną i że jej celem jest, przy zagwarantowaniu niezbędnego stopnia jednolitości procedury, pozostawienie ustawodawcy swobody $\mathrm{w}$ regulowaniu pewnych kwestii szczególnych. Osiągnięto to, posługując się typowym dla ustaw austriackich sformułowaniem „o ile przepisy szczególne nie stanowią inaczej”, wprowadzając $\mathrm{w}$ ten sposób zastrzeżenie pierwszeństwa stosowania w pewnych przypadkach przepisów szczególnych.

Metodę tę zastosowano we wszystkich kodyfikacjach państw sukcesji habsburskiej, w których odstępstwa od unormowań kodeksowych wprowadzano głównie poprzez włączanie regulacji procesowych do ustaw prawa materialnego. W związku z tym aktualny stan postępowania administracyjnego określa się w nich przeważnie jako „kombinację regulacji ogólnych i szczególnych”6. Te ostatnie, prócz podstawowego przedmiotu ich unormowania, regulują także procesowe aspekty wykonywania przez organy administracji zadań w poszczególnych zakresach (prawa budowlanego, celnego itd.), odmiennie niż czyni to ustawa o postępowaniu administracyjnym, która w tych przypadkach ma zastosowanie wyłącznie subsydiarne.

Ukształtowany w ten sposób i z czasem pogłębiający się dualizm proceduralny doprowadził do utrwalenia się podziału postępowania administracyjnego na „ogólne” i „szczególne”. Dość szybko dały o sobie znać tego konsekwencje, prowadzące nieuchronnie do rozproszenia regulacji procesowej i w efekcie - marginalizacji roli kodyfikacji. Negatywnych skutków tego zjawiska w żadnym z państw sukcesji habsburskiej nie udało się, jak dotąd, wyeliminować - ani w drodze nowelizacji, ani w drodze rekodyfikacji. Nie zapobiegło też nadmiernym odstępstwom od regulacji ogólnej wprowadzanie prawnych ograniczeń stanowienia przepisów

5 F. Staničić, Das Verwaltungsverfahren in Kroatien, [w:] Vergleichendes Verwaltungsrecht in Südosteuropa, s. 234.

6 J. Machajová, Das Verwaltungsverfahren in der Slowakei, [w:] Vergleichendes Verwaltungsrecht in Ostmitteleuropa, s. 290. 
szczególnych. W Austrii przewiduje je art. 11 ust. 2 Konstytucji (Bundes-Verfassungsgesetz - B-VG) ${ }^{7}$, który dopuszcza wyjątki od ustanowionych w AVG reguł tylko wtedy, gdy jest to "niezbędne do uregulowania przedmiotu postępowania”. Mimo akcentowanej w orzecznictwie austriackiego Trybunału Konstytucyjnego dopuszczalności takiego zabiegu tylko pod warunkiem jego „nieodzowności”, nie udało się uniknąć zjawiska nadmiernego rozproszenia regulacji procesowej w ustawach prawa materialnego ${ }^{8}$. Pożądanego poziomu unifikacji postępowania administracyjnego nie osiągnięto również $\mathrm{w}$ innych systemach prawnych, $\mathrm{w}$ których zdecydowano się na wariant rekodyfikacji. Nie zdołał do tego doprowadzić przewidziany w chorwackiej ustawie nakaz jej stosowania we wszystkich sprawach administracyjnych, $\mathrm{z}$ dopuszczalnością stanowienia wyjątków w przepisach szczególnych tylko wtedy, gdy jest to niezbędne i nie stoi w sprzeczności z jej założeniami i celem. W związku z treścią tego przepisu powstał tam natomiast problem, co jest jeszcze dopuszczalne, a co już nie, pogłębiając tylko stan niepewności prawnej i związany tym wzrost wpływu środków zaskarżenia na drodze administracyjnej i sądowej9.

Uzasadnia to przekonanie, że najbardziej nawet restrykcyjne ograniczenia zakresu dopuszczalności odstępstw od regulacji ogólnej nie są w stanie zapobiec ekspansji przepisów szczególnych. Ten stan rzeczy zdaje się akceptować węgierski ustawodawca, który w kodeksie z 2016 r. o ogólnym postępowaniu administracyjnym wprowadził katalog wyłączeń jego stosowania w niektórych dziedzinach (m.in. prawo podatkowe, celne, wyborcze) z zastrzeżeniem, że w zakresie tym katalogiem nie objętym odstępstwa od postanowień kodeksu są dopuszczalne tylko wtedy, gdy on sam na to zezwala. Jednocześnie przewidziano dopuszczalność stanowienia uzupełniających, zgodnych z nim przepisów, w drodze rozporządzeń organów władzy wykonawczej (z wyjątkiem ministrów). Ten racjonalny zabieg miał na celu osiągnięcie stanu łączności między unormowaniem kodeksowym a przepisami szczególnymi, które muszą mieścić się „w ramach” wyznaczonych przez kodeks. Wykluczając możliwość stanowienia przepisów odrębnych ad hoc, w oderwaniu od założeń kodeksu i wbrew jego postanowieniom, uczyniono w ten sposób ważny krok w kierunku ujednolicenia postępowania administracyjnego.

Doświadczenia te pokazują, że sens utrzymywania podziału na prawo administracyjne ogólne i szczególne wydaje się być coraz bardziej wątpliwy. Chcąc określić granice postępowania administracyjnego, nie można przecież abstrahować od ujętych w ramach kodyfikacji wyłączeń jej stosowania oraz odesłań i zastrzeżeń stosowania przepisów odrębnych, które wraz z nią tworzą w sumie złożony wprawdzie, ale jednak dopiero wtedy zupełny system postępowania administracyjnego.

7 Konstytucja Republiki Austrii z 1.01.1930 r., BGBI Nr 1./1930 ze zm.

8 J. Hengstschläger, Verwaltungsverfahrensrecht, Wien 2009, s. 35-36.

9 F. Staničić, Das Verwaltungsverfahren in Kroatien..., s. 237. . 


\section{Strona postępowania administracyjnego}

Jednym z najważniejszych elementów austriackiej tradycji prawnej jest pojęcie strony postępowania administracyjnego (Partei). Jak wynika z $\$ 8$ AVG, kryterium odróżnienia strony od innych uczestników postępowania jest jej uczestnictwo w postępowaniu na podstawie roszczenia prawnego (Rechtsanspruch) lub interesu prawnego (rechtliches Interesse). Mimo przyjętego w przepisie rozróżnienia nie ulega wątpliwości, że zarówno roszczenie prawne, jak i interes prawny są formami realizacji prawa podmiotowego, a różnica między nimi tkwi w tym, że pierwsze oznacza materialnoprawne roszczenie o określone treściowo zachowanie się władzy, drugie zaś jest roszczeniem o postępowanie we własnej sprawie, które nie daje jednak prawa do określonej treści aktu władzy publicznej. Podstaw każdego z nich należy poszukiwać w prawie materialnym, AVG stwarza bowiem tylko ramy, których treść w każdym przypadku wypełnia prawo materialne ${ }^{10}$.

Materialna koncepcja strony została przyjęta we wszystkich kodyfikacjach państw sukcesji habsburskiej, mimo że nie posłużono się w nich dosłownie sformułowaniami użytymi w AVG. Konstruując pojęcie strony, odstąpiono w nich od typowego dla prawa austriackiego określenia „roszczenie prawne”, poprzestając na warunku istnienia „interesu prawnego” lub „prawnie chronionego interesu” i uzupełniając je czasem dodatkowymi zastrzeżeniami (jak prawo czy obowiązek). Typowym tego przykładem jest polski kodeks, który mianem strony określa każdego, czyjego „interesu prawnego lub obowiązku” dotyczy postępowanie albo kto żąda czynności organu ze względu na swój „interes prawny lub obowiązek”. Odpowiednika tego pojęcia używa ustawa słowacka, która status strony w postępowaniu administracyjnym uzależnia od istnienia jej „praw, prawnie chronionych interesów lub obowiązków”, podobnie jak ustawa słoweńska, chorwacka czy serbska oraz węgierski kodeks z 2016 r. Mimo przyjęcia austriackiej koncepcji strony, nie we wszystkich kodyfikacjach państw z kręgu tej tradycji posłużono się pojęciem „strona”. W niektórych z nich, tak jak w czeskiej, odstąpiono od niego na rzecz „uczestnika postępowania”, motywując to potrzebą odejścia w postępowaniu administracyjnym od nazewnictwa typowego dla klasycznego postępowania spornego (sądowego $)^{11}$.

W przeważającej większości państw sukcesji habsburskiej przyjęto także będący elementem tej tradycji podział na kategorie stron postępowania, wyróżniane ze względu na sposób i intensywność udzielanej im ochrony: stronę główną (Hauptpartei), uboczną (Nebenpartei), przeciwną (Gegenpartei), a także podmioty, którym prawo materialne przyznaje status strony (Legalpartei).

10 L.K. Adamovich, B.-K. Funk, Allgemeines..., s. 376.

11 D. Hendrych, Das Verwaltungsverfahren in Tschechien, [w:] Vergleichendes Verwaltungsrecht in Ostmitteleuropa, s. 265. 
Oprócz tego wyróżnia się - ze względu na sposób wszczęcia postępowania - stronę aktywną i pasywną (aktive und passive Partei).

Do konstrukcji strony legalnej nawiązuje wprost ustawa czeska i węgierski kodeks z 2016 r., który przewiduje, że w pewnych przypadkach status strony może być przyznany ustawą lub dekretem rządowym. Pojęciem strony głównej i ubocznej, ewentualnie określeniem „interwenient”, posługują się kodyfikacje chorwacka, słoweńska, serbska i macedońska. Stroną uboczną czy też interwenientem jest według nich osoba, która bierze udział w postępowaniu dotyczącym innej osoby (strony aktywnej lub pasywnej) ze względu na potrzebę ochrony jej własnych praw lub interesu prawnego i dlatego ona również jest stroną tego postępowania. Austriacką spuścizną prawną jest także koncepcja osoby zainteresowanej, do dziś znajdująca normatywne umocowanie w $\$ 8$ AVG, z którego wynika, że uczestnikami postępowania są osoby, które żądają czynności organu lub do których czynność organu się odnosi, ale nie mają w sprawie roszczenia lub interesu prawnego. Posiadanie przez nie interesu tylko faktycznego sprawia, że dysponują one, podobnie jak w Austrii, nieznacznym zakresem uprawnień w postępowaniu, takich jak prawo przeglądania akt (Słowenia) czy uczestnictwa w rozprawie (Polska).

Przyjęta w AVG koncepcja strony, wiążąca wprost ów status uczestnika postępowania $\mathrm{z}$ interesem prawnym, jest charakterystyczną cechą kodyfikacji austriackiej, odróżniającą ją od systemów, w których konstrukcję tę oparto na kryteriach formalnych. Jej podstawową funkcją jest koncentracja norm postępowania (normökonomische Funktion) ${ }^{12}$ o charakterze gwarancyjnym (prawo do wysłuchania, otrzymania decyzji, wniesienia środków odwoławczych czy uruchomienia trybów nadzwyczajnych oraz zwalczania bezczynności organu). Ustanowiony w ten sposób standard wszedł na stałe do porządków prawnych państw sukcesji habsburskiej, stanowiąc dziś utrwalony element europejskiej kultury prawnej.

\section{Decyzja administracyjna}

Pojęcie decyzji administracyjnej (Bescheid) jest klasyczną konstrukcją prawa austriackiego o konstytucyjnej randze i proceduralnym rodowodzie. Użyto go po raz pierwszy w pierwotnej wersji AVG, a następnie posłużono się nim w B-VG na oznaczenie jednej z form tworzenia prawa. W orzecznictwie i nauce przyjmuje się zgodnie, że konstytucyjne i procesowe pojęcie decyzji jest identyczne i obejmuje ono akt o następujących cechach: jest to władcza forma działania administracji skierowana do indywidualnie oznaczonej osoby w stosunku

12 J. Hengstschläger, Verwaltungsverfahrensrecht..., s. 83. 
zewnętrznym i wydana w sposób sformalizowany. Jej istotę oddaje znany pogląd austriackiego Trybunału Konstytucyjnego, zgodnie z którym decyzją jest każdy akt organu administracji publicznej, kształtujący lub stwierdzający indywidualny stosunek prawny, niezależnie od tego, czy akt taki został wydany w formie decyzji administracyjnej, czy też nie. Stąd wywiedziono skierowany do ustawodawcy nakaz ustanowienia zestawu cech decyzji, które - z procesowego punktu widzenia - pozwolą na taką jej kwalifikację ${ }^{13}$. Wśród cech identyfikujących akt administracyjny jako decyzję wymienia się w AVG wyraźne jego oznaczenie (decyzja), rozstrzygnięcie i pouczenie o środkach zaskarżenia $(\$ 58,59$ i 61). Do elementów decyzji zalicza się nadto uzasadnienie, w którym należy podać wyniki postępowania dowodowego $(\$ 60)$.

Koncepcja decyzji administracyjnej wraz z rygorami jej wydawania została przejęta przez państwa sukcesji habsburskiej i do dziś znajduje odzwierciedlenie w ich kodyfikacjach. We wszystkich z nich znalazło odbicie założenie, że decyzja jest władczym, wydanym w sformalizowanej procedurze aktem administracyjnym organu administracji, stanowiącym wiążące rozstrzygnięcie o prawach lub obowiązkach indywidualnie oznaczonego podmiotu. We wszystkich też przyjęto triadę zasadniczych wymagań stawianych decyzji w postaci rozstrzygnięcia, uzasadnienia i pouczenia o środkach prawnych.

Nieznane w Austrii odstępstwa od niektórych z tych wymagań wprowadzono w ostatnim czasie w kilku europejskich kodyfikacjach w związku z dążeniem do usprawnienia postępowania administracyjnego. W Polsce uczyniono to m.in. przez włączenie do kodeksu postępowania administracyjnego postępowania uproszczonego, przewidując w związku z tym uproszczone uzasadnienie wydanej w ten sposób decyzji. Z obowiązku sporządzania uzasadnienia organ został także zwolniony - siłą rzeczy - w przypadku milczącego załatwienia sprawy. Podobne rozwiązania zostały wprowadzone wcześniej w węgierskim systemie prawnym, gdzie odróżnia się decyzje formalne od decyzji uproszczonych i odformalizowanych. Dwie ostatnie nie wymagają uzasadnienia, bądź ze względu na zawarcie ugody między stronami, bądź gdy stan faktyczny organ uznał za ustalony na podstawie wniosku strony i danych znanych mu z urzędu, a brak było strony przeciwnej (decyzje uproszczone), bądź też w przypadku decyzji wydawanych na urzędowych formularzach, albo gdy sprawa została załatwiona milcząco (decyzje odformalizowane ${ }^{14}$. Analogiczne regulacje znalazły się w kodeksie z 2016 r. Dalej jeszcze idące uproszczenie przewidziano w ustawie chorwackiej, dopuszczającej wydanie decyzji w sprawach mniejszej wagi w drodze adnotacji w aktach sprawy, gdy podstawy ku temu są oczywiste i nie narusza to interesu publicznego albo osób trzecich. Z podobnych powodów można odstą-

13 Ibidem, s. 261-263.

14 I. Vadál, Das Verwaltungsverfahren in Ungarn, [w:] Vergleichendes Verwaltungsrecht in Ostmitteleuropa, s. 352-353. 
pić od uzasadnienia decyzji, w tym wydawanej w formie zarządzeń ogólnych, w systemie macedońskim.

Elementem austriackiej tradycji jest także uwzględniony we wszystkich niemal kodyfikacjach państw byłej monarchii habsburskiej podział rozstrzygnięć wydawanych w postępowaniu administracyjnym na decyzje i postanowienia (Verfahrensanordnungen). Te ostatnie, w odróżnieniu od decyzji, są rozstrzygnięciami wyłącznie procesowej natury i odnoszą się zwykle do toku postępowania. W takim ujęciu znane są one polskiej procedurze administracyjnej, a także ustawie czeskiej, węgierskiej, słoweńskiej, chorwackiej, serbskiej i macedońskiej. Wyjątkiem jest kodyfikacja słowacka, która posługuje się jednolitym pojęciem decyzji, wyróżniając wśród nich - będące odpowiednikiem postanowień - decyzje procesowe. Różnice między decyzją a postanowieniem dotyczą - $\mathrm{w}$ związku $\mathrm{z}$ przedmiotem ich rozstrzygnięcia - również sposobu ich wydawania i zaskarżania. W odróżnieniu od decyzji, które zwykle wydawane są w formie pisemnej, postanowienia mogą być ogłaszane ustnie. $Z$ reguły też - tak jak w Austrii ( $\$ 63$ ust. 2 AVG) - podlegają one zaskarżeniu jedynie $\mathrm{w}$ odwołaniu od decyzji. Wyjątkiem jest ustawa macedońska i polska, gdzie przewidziano możliwość wniesienia na nie zażalenia, jeżeli kodeks tak stanowi.

Katalog form zakończenia postępowania administracyjnego $\mathrm{w}$ państwach sukcesji habsburskiej podlegał z biegiem lat pewnym modyfikacjom. Pierwotnie uzupełniono go o ugodę administracyjną ( $w$ Polsce, Cechach, na Słowacji i na Węgrzech), będącej formą polubownego załatwienia sprawy między stronami o spornych interesach. Z czasem, głównie pod wpływem rozwiązań niemieckich, rozszerzono go o umowę administracyjną (na Węgrzech, w Czechach, Chorwacji, Serbii, Słowenii i Macedonii, choć w tej ostatniej kwalifikuje się ją jako akt administracyjny), akty generalne (w Czechach i Macedonii) oraz milczące załatwienie sprawy w postaci bądź milczącej zgody organu (na Węgrzech, w Chorwacji i w Polsce), bądź milczącego odrzucenia wniosku - ze skutkiem uznania decyzji za niewydaną (Słowenia).

Inspiracje te, uzasadnione potrzebą zwiększenia poziomu efektywności postępowania administracyjnego, są w pełni zrozumiałe. Nie można ich było poszukiwać w systemie austriackim, gdzie możliwość wprowadzenia innych niż decyzja sposobów zakończenia postępowania wyklucza zamknięty przez art. 130 B-VG katalog form działania administracji. Stąd coraz wyraźniej zaznacza się wpływ na postępowanie administracyjne państw sukcesji habsburskiej rozwiązań przyjętych w innych porządkach prawnych, głównie niemieckich. Ich wykorzystanie w krajowych systemach prawnych nie podważa jednak wypracowanej w XIX-wiecznej Austrii koncepcji decyzji, niezmiennie uznawanej za podstawową formę załatwienia sprawy administracyjnej. 


\section{5. Środki ochrony prawnej na drodze administracyjnej}

Cechą charakterystyczną austriackiej kodyfikacji jest koncepcja ochrony prawnej (Rechtsschutz), ukierunkowanej z jednej strony na ochronę praw podmiotowych strony, z drugiej zaś - na zapewnienie zgodności rozstrzygnięć administracji $\mathrm{z}$ obiektywnym porządkiem prawnym. Znalazło to odzwierciedlenie w przepisach części IV AVG, w ramach której ujęto katalog instrumentów mających na celu zapewnienie tak rozumianej ochrony: odwołanie (Berufung) ${ }^{15}$, uchylenie lub zmiana decyzji z urzędu (Abänderung und Behebung von Amts wegen), stwierdzenie jej nieważności (Nichtigkeit), a także wznowienie postępowania (Wiederaufnahme der Verfahrens). Katalog ten uzupełniono o środek ochrony przed bezczynnością administracji (Devolutionsantrag).

Wśród przewidzianych w postępowaniu administracyjnym środków ochrony prawnej (Rechtsmittel) wyróżniono w związku z tym środki zaskarżenia (Rechtsbehelf), które dają stronie roszczenie o wydanie decyzji oraz środki nadzoru (Aufsichtsmittel), w przypadku których organ działa z urzędu i stronie nie przysługuje w związku z tym żadne roszczenie. Do środków prawnych sensu stricto, rozumianych jako środki skierowane przeciwko decyzji niekorzystnej dla strony, zaliczono: zwyczajne i nadzwyczajne, gdzie te ostatnie mogą być wniesione tylko w określonych warunkach i z określonych powodów; dewolutywne, przenoszące sprawę do organu hierarchicznie wyższego i niedewolutywne (remonstratywne), na skutek których w sprawie orzeka organ, który wydał decyzję; suspensywne, wstrzymujące wykonanie decyzji i niesuspensywne, których wniesienie wykonania decyzji nie wyklucza, kasacyjne, ukierunkowane na uchylenie decyzji oraz reformatoryjne, zorientowane na wydanie innej decyzji w miejsce zaskarżonej ${ }^{16}$.

Podstawowym, przewidzianym w AVG środkiem ochrony praw podmiotowych strony było odwołanie (\$ 63-67). Miało ono charakter środka zaskarżenia zwyczajnego, dewolutywnego i suspensywnego oraz reformatoryjnego. Jego cel stanowiła weryfikacja decyzji (Überprüfung) w administracyjnym toku instancji (Instanzenzug), którego zakres pozostawiono do uregulowania w przepisach szczególnych. Odwołanie zostało pomyślane jako środek odformalizowany, należało w nim jedynie oznaczyć zaskarżoną decyzję i uzasadnić żądanie. Termin na jego wniesienie wynosił 2 tygodnie od dnia doręczenia lub ogłoszenia decyzji; od tej chwili także strona mogła zrzec się odwołania. W postępowaniu odwoławczym dopuszczalne było prowadzenie postępowania dowodowego, choć tylko w uzupełniającym zakresie, w tym również na wniosek strony, której nie obowiązywał zakaz „nowości” (kein

15 Pojęcie „odwołania” w wersji pierwotnej AVG obejmowało także rekurs i zażalenie (Rekurs, Beschwerde) oraz przedstawienie (Vorstellung) - zob. § 63 AVG.

16 R. Thienel, Verwaltungsverfahrensrecht, Wien 2006, s. 242-243. 
Neuerungsverbot). W razie uwzględnienia odwołania organ odwoławczy miał obowiązek wydać decyzję co do zasady merytoryczną (o zmianie zaskarżonej decyzji), a tylko wyjątkowo kasacyjną. Przy wydawaniu decyzji odwoławczej nie obowiązywał zakaz reformatio in peius.

Pozostałe przewidziane w AVG środki zaskarżenia, mają charakter nadzwyczajny. Należy do nich wniosek o wznowienie postępowania, który przysługuje od decyzji ostatecznej i gdy zachodzi co najmniej jedna z podstaw wznowienia w postaci: 1) wydania decyzji na podstawie fałszywych dowodów, 2) wyjścia na jaw nowych okoliczności faktycznych lub dowodów, które bez winy strony nie były znane w postępowaniu zakończonym zaskarżoną decyzją, a mogły mieć wpływ na wynik sprawy oraz 3) rozstrzygnięcia zagadnienia wstępnego przez właściwy organ lub sąd odmiennie od oceny przyjętej przy wydaniu decyzji (\$69). Pod tymi samymi warunkami wznowienie postępowania może być uruchomione również $\mathrm{z}$ urzędu $\mathrm{w}$ ramach nadzoru. W każdym $\mathrm{z}$ tych przypadków organem właściwym do wznowienia postępowania jest organ, który wydał decyzję w ostatniej instancji.

Do środków nadzoru w czystej postaci należy uruchomienie z urzędu postępowania w celu uchylenia lub zmiany decyzji, na mocy której nikt nie nabył prawa ( $\$ 68$ ust. 1). Organem właściwym w tym zakresie jest organ, który wydał decyzję lub organ wyższego stopnia. Pozostałe decyzje mogą być uchylane, o ile jest to niezbędne dla ochrony wartości w ustawie wskazanych, przy poszanowaniu praw nabytych ( $\$ 68$ ust. 3). Poza tym, wyłącznie w trybie nadzoru, można stwierdzić nieważność decyzji, gdy: 1) została ona wydana przez niewłaściwy organ lub niewłaściwie obsadzony organ kolegialny, 2) jej wykonanie wywołałoby skutek zagrożenia karą, 3) jest ona faktycznie niewykonalna, 4) lub dotknięta wadą nieważności z mocy prawa ( $\$ 68$ ust. 4). Nie można jednak stwierdzić nieważności decyzji z pierwszego powodu po upływie 3 lat od daty uzyskania przez decyzję waloru ostateczności.

Austriacka koncepcja ochrony prawnej na drodze administracyjnej została przyjęta we wszystkich bez wyjątku państwach sukcesji habsburskiej. Ich kodyfikacje zawierają system środków prawnych o zróżnicowanym charakterze, zorientowanych zarówno na ochronę interesu jednostkowego (środki zaskarżenia), jak i interesu publicznego (środki nadzoru). W ramach środków zaskarżenia funkcjonują środki prawne zwyczajne przysługujące stronie wobec decyzji nieostatecznej oraz nadzwyczajne ukierunkowane na podważenie decyzji ostatecznej, pod warunkiem zaistnienia podstaw określonych w ustawie.

Do zwyczajnych środków prawnych należy odwołanie w administracyjnym toku instancji, we wszystkich państwach byłej Monarchii Habsburskiej ograniczonym do dwóch. Odstępstwa od tej zasady mają różny zakres. Najdalej idące wprowadzono w samej Austrii, gdzie w związku z reformą sądownictwa administracyjnego zniesiono - z mocą od 1 stycznia 2014 r. - administracyjny tok instancji, zachowując go tylko w sprawach municypalnych. W innych państwach nie zdecydowano się, jak dotąd, na takie posunięcie, choć i tu coraz częściej za wystarczającą uznaje się ochronę udzielaną na drodze sądowej. Widoczne jest to w tych 
systemach, w których wykluczona jest możliwość wniesienia odwołania od wydanych w I instancji decyzji niektórych organów, głównie dlatego, że nie mają organu nadrzędnego (np. ministrowie, organy samorządowe). Przykładowo, w obu kodyfikacjach węgierskich przyjęto, że uchylenia lub zmiany takich decyzji jej adresat może dochodzić bezpośrednio na drodze sądowej. W Słowenii wątpliwości co do konstytucyjności takich rozwiązań rozstrzygnięto $\mathrm{w}$ najnowszym orzecznictwie na rzecz ich dopuszczalności, pod warunkiem zagwarantowania stronie, w miejsce odwołania, skutecznego środka ochrony sądowej ${ }^{17}$. W innych systemach, jak np. Czechach czy Słowacji, nie zrezygnowano w takich przypadkach z zasady dwuinstancyjności, zapewniając ją przez zastąpienie odwołania jego odpowiednikiem w postaci wniosku o ponowne rozpatrzenie sprawy, przysługującego do tego samego organu lub kierownika organu, który decyzję wydał. Rozwiązanie pośrednie przyjęto ostatnio w Polsce, przewidując możliwość złożenia przez stronę wniosku o ponowne rozpatrzenie sprawy w postępowaniu administracyjnym bądź też skorzystania od razu z ochrony sądowej - z pominięciem tego trybu.

Poza tym odwołanie w systemach prawnych państw sukcesji habsburskiej zachowało swój klasyczny charakter. Przysługuje ono stronie od każdej decyzji w celu jej weryfikacji pod kątem zgodności z prawem, a niektórych nowszych kodyfikacjach - także pod względem celowości (Serbia, Macedonia). Cechą tych ostatnich jest rozciąganie prawa do odwołania na nowe formy załatwienia sprawy, takie jak tzw. decyzje milczące (Serbia, Macedonia), a tam gdzie nie jest to możliwe - uzupełnianie katalogu zwyczajnych środków prawnych o nowe instrumenty. Należy do nich przewidziany w chorwackiej ustawie sprzeciw, przysługujący m.in. w związku z zawarciem umowy administracyjnej, w tym na niewykonanie jej postanowień przez organ. Niezmienna jest zasada, że odwołanie jest środkiem suspensywnym, a organ, który decyzję wydał, może postanowić o natychmiastowym jej wykonaniu z przyczyn przewidzianych w ustawie.

We wszystkich niemal państwach sukcesji habsburskiej odwołanie jest odformalizowane (wyjątkiem jest ustawa węgierska z 2016 r., która wymaga uzasadnienia odwołania). Termin na jego wniesienie wynosi zwykle 15 dni od doręczenia lub ogłoszenia decyzji. W tym też terminie strona może zrzec się odwołania (ustawy czeska, słowacka, węgierska i polska) i oświadczenie takie jest nieodwołalne. Wedle tych samych, klasycznych zasad zorganizowano przebieg postępowania odwoławczego, z uprawnieniami organu I instancji do autokorekty wydanej decyzji i obowiązkiem przekazania odwołania organowi nadrzędnemu dopiero w razie stwierdzenia braku podstaw do uwzględnienia odwołania. Zakres uprawnień organu I instancji na tym etapie kształtuje się różnie - od wąskich, ograniczonych do uchylenia lub zmiany zaskarżonej decyzji, gdy odwołanie zasługuje na uwzględnienie w całości, a wniosły je wszystkie strony (Polska, Czechy, Słowacja,

17 E. Kerševan, Das Verwaltungsverfahren in Slowenien, [w:] Vergleichendes Verwaltungsrecht in Südosteuropa, s. 219. 
Węgry), po szerokie, polegające na obowiązku prowadzenia przez organ I instancji uzupełniającego postępowania dowodowego z możliwością uchylenia lub zmiany zaskarżonej decyzji (Słowenia, Serbia, Macedonia), a także oddalenia środka odwoławczego (Chorwacja).

Organ odwoławczy bada sprawę w pełnym zakresie i w tym celu może prowadzić uzupełniające postępowanie wyjaśniające, uwzględniając w jego ramach powołane przez stronę nowe fakty i dowody. Odstępstwo od tej zasady przewidziano w kodyfikacji czeskiej i węgierskiej, które „nowości” w postępowaniu odwoławczym dopuszczają tylko wtedy, gdy strona w postępowaniu I instancji o nich nie wiedziała albo nie mogła się na nie powołać z niezawinionych przez siebie przyczyn. Z kolei wyjątek od zasady prowadzenia postępowania dowodowego w uzupełniającym zakresie wprowadził w 2017 r. polski ustawodawca, przewidując możliwość przeprowadzenia tego postępowania przez organ odwoławczy „w niezbędnym zakresie” za zgodą wszystkich stron.

Klasycznej austriackiej koncepcji odpowiadają też zasady orzekania przez organ odwoławczy. Gdy nie uwzględnia on odwołania, utrzymuje w mocy decyzję organu I instancji (oddala odwołanie), natomiast gdy uznaje je za uzasadnione, ma obowiązek rozstrzygnąć sprawę merytorycznie. Decyzję kasacyjną może on wydać tylko wtedy, gdy stwierdzi potrzebę przeprowadzenia ponownie postępowania dowodowego. W niektórych ustawach warunki jej wydania mniej lub bardziej ograniczono, przewidując np. że może to nastąpić, gdy usunięcie wad postępowania będzie szybsze i bardziej ekonomiczne w postępowaniu przed organem I instancji (Słowenia) bądź też, że nie może to nastąpić, gdy organ odwoławczy prowadził postępowanie dowodowe w zakresie niezbędnym dla rozstrzygnięcia sprawy (Polska).

We wszystkich, z wyjątkiem Węgier, państwach byłej Monarchii Habsburskiej przewidziano też nadzwyczajny środek ochrony w postaci wniosku o wznowienie postępowania. Ujęto go tradycyjnie jako środek skierowany przeciw decyzji ostatecznej, który musi być oparty określonych ustawowo podstawach. Katalog tych podstaw jest szerszy lub węższy, jednak wszystkie one wiążą się z ciężkimi wadami postępowania zakończonego zaskarżoną decyzją. Wniosek o wznowienie postępowania strona może przy tym złożyć tylko w określonym ustawą terminie, zwykle 30-dniowym lub miesięcznym od powzięcia wiadomości o okoliczności uzasadniającej wznowienie postępowania (termin podmiotowy). Dłuższe terminy przewidziano dla organu, który może postępowanie wznowić z urzędu w ramach kompetencji nadzorczych (termin przedmiotowy). W Chorwacji organ może to uczynić w zasadzie nie później niż w ciągu 3 lat od doręczenia decyzji, a w Czechach i na Słowacji - w tym samym czasie, tyle że liczonym od ustatecznienia się decyzji. Znacznie dłuższe terminy w tym zakresie przewidziano w polskiej kodyfikacji (5 i 10 lat w zależności od podstawy wznowienia). Zasadą jest, że organem właściwym w sprawie wznowienia jest organ, który wydał decyzję. W wyniku wznowienia postępowania może dojść do pozostawienia w obrocie decyzji 
dotychczasowej lub wydania nowej, na mocy której poprzednia decyzja traci moc. Od wydanej w ten sposób decyzji służy stronie zwyczajny środek prawny.

Wszystkie kodyfikacje państw sukcesji habsburskiej przewidują też nadzwyczajne środki prawne o charakterze nadzorczym, choć odstępstwa od koncepcji austriackiej są tu najbardziej widoczne. W niektórych państwach nie uwzględniono w ogóle niektórych z typowych dla AVG konstrukcji, takich jak stwierdzenie nieważności decyzji (w Czechach do czasu kodyfikacji z 2004 r., a na Słowacji do dziś) czy wznowienie postępowania (na Węgrzech). W innych doszło do ich modyfikacji poprzez „rozszczepienie” na wiele instytucji, takich jak: uchylenie, zmiana i uznanie decyzji za nieważną (Macedonia), uchylenie i pozbawienie mocy wiążącej, nadzwyczajne pozbawienie mocy wiążącej i stwierdzenie nieważności (Słowenia, Serbia), uchylenie i zmiana za zgodą strony (Serbia, Polska). W niektórych nowszych kodyfikacjach zdecydowano się na zabieg redukcji trybów nadzwyczajnych przez ich kompilację lub czasowe ograniczenie możliwości ich uruchomienia. Cel taki przyświecał twórcom chorwackiej ustawy, w której tryby te (poza wznowieniem postępowania) ograniczono do stwierdzenia nieważności decyzji oraz uznania jej za nieważną i uchylenia. W ramach tego ostatniego można decyzję uchylić lub uznać ją za nieważną w zależności od tego, czy była zgodna z prawem, czy nie, $\mathrm{z}$ uwzględnieniem zasady ochrony praw nabytych. Od tego trybu odróżnia się stwierdzenie nieważności decyzji ze skutkiem ex tunc, zastrzeżone dla eliminacji z obrotu decyzji dotkniętych szczególne ciężkimi wadami, takimi jak wydanie decyzji w sprawie zastrzeżonej do właściwości sądu bądź która nie powinna być załatwiona w postępowaniu administracyjnym albo gdy decyzja jest niewykonalna, bądź jej wykonanie wywołałoby czyn zagrożony karą. Decyzja o stwierdzeniu nieważności może być wydana przez organ, który wydał decyzję, jak i organ wyższego stopnia zarówno na wniosek strony, jak i z urzędu ${ }^{18}$. Odmienne od klasycznego rozwiązanie kwestii trybów nadzwyczajnych zawiera też węgierski kodeks z 2016 r. Do przewidzianych w nim środków ochrony podejmowanych wyłącznie z urzędu zaliczono (obok żądania prokuratora) jedynie tryb zmiany i odwołania decyzji w ramach rzeczowej właściwości organu oraz postępowania nadzorczego. Wchodzą one w grę w przewidzianym w ustawie krótkim terminie i pod warunkiem, że wadliwa decyzja nie była poddana weryfikacji w żadnym innym trybie, $\mathrm{z}$ zastrzeżeniem obowiązku zapewnienia ochrony praw nabytych. W ustawie ujęto też podstawy nieważności decyzji, uzasadniające stwierdzenie jej nieważności lub odwołanie. Stanowią one kompilację klasycznych podstaw nieważności (wydanie decyzji przez organ niewłaściwy lub której treść rodzi zagrożenie karą) i wznowienia postępowania (w postępowaniu byłby możliwy udział innych stron).

Niełatwy problem kolizji między potrzebą zapewnienia stabilności decyzji i jej zgodności z prawem doprowadziło do daleko idącego zróżnicowania nadzwyczajnych trybów jej weryfikacji. Wprawdzie wszystkie one nadal, zgodnie

18 F. Staničić, Das Verwaltungsverfahren in Kroatien..., s. 234 i 259. 
z tradycyjnym ujęciem, stwarzają podstawę do następczej weryfikacji decyzji ostatecznej z określonych $\mathrm{w}$ ustawie przyczyn, ale na tym cechy wspólne się kończą. Uzasadnia to przekonanie, że austriacka koncepcja ochrony prawnej na drodze administracyjnej nie do końca przystaje do potrzeb współczesnej praktyki.

Odstępstwa od typowych dla AVG rozwiązań dotyczą też środków ochrony przed bezczynnością organu administracji. W żadnym z państw byłej Monarchii Habsburskiej nie zdecydowano się na przyjęcie typowej dla kodyfikacji austriackiej konstrukcji wniosku dewolucyjnego. Zgodnie z AVG, przysługiwał on stronie do organu wyższego stopnia $\mathrm{w}$ razie niewydania decyzji przez organ I instancji w określonym jako maksymalny, 6-miesięcznym terminie od wniesienia żądania, w wyniku czego właściwość do rozpatrzenia sprawy przechodziła na organ wyższego stopnia, który orzekał $w$ tej sprawie jako organ I instancji ( $\$ 73$ AVG). Koncepcja ta została zmodyfikowana w samej Austrii w związku z reformą sądownictwa administracyjnego. Od 1 stycznia 2014 r. wniosek dewolucyjny przysługuje tam tylko w sprawach municypalnych, natomiast w pozostałych strony mogą skorzystać ze środka ochrony sądowej w postaci skargi na opieszałość organu (Säumnisbeschwerde), której uwzględnienie oznacza przejęcie sprawy do rozpoznania i merytorycznego rozstrzygnięcia przez sąd administracyjny. W innych systemach prawnych ochrony przed bezczynnością organu można dochodzić na drodze administracyjnej poprzez wniesienie skargi (zażalenia, ponaglenia) do organu wyższego stopnia. Organ ten może zastosować środki niezbędne do usunięcia stanu zwłoki (Węgry), w tym wyznaczyć organowi I instancji termin załatwienia sprawy (Polska) lub także przejąć sprawę do rozstrzygnięcia (Chorwacja, Serbia, Macedonia, Czechy, Słowacja), w żadnym jednak razie nie jest do tego zobowiązany. Ochronę przed bezczynnością administracji zapewnia też - nieznana w Austrii - konstrukcja fikcji pozytywnego załatwienia sprawy w razie niewydania decyzji w określonym prawem terminie. W tych państwach, w których przyjęto fikcję odrzucenia wniosku, środkiem zwalczania bezczynności organu jest odwołanie od takiej decyzji (Słowenia).

\section{Konkluzje}

Wszystko to nie podważa jednak w żadnym stopniu znaczenia austriackiej myśli kodyfikacyjnej w kształtowaniu zrębów europejskiej kultury prawnej. Przyjęte w AVG rozwiązania przetrwały w większości systemów prawnych państw sukcesji habsburskiej, stanowiąc dziś - jako utrwalony standard - punkt wyjścia dla dalszych, dostosowanych do potrzeb współczesności zmian. Świadczą o tym doświadczenia państw, w których zdecydowano się na modyfikację postępowania administracyjnego, bądź przez rezygnację z niektórych klasycznych jego instytucji, 
takich jak administracyjny tok instancji (Austria), bądź przez ich kompilację, tak jak w przypadku nadzwyczajnych trybów weryfikacji decyzji (Chorwacja, Węgry) albo uzupełnienie o nowe rozwiązania w postaci milczącego załatwienia sprawy (Węgry, Chorwacja, Słowenia, Polska), umowy administracyjnej (Węgry, Czechy, Chorwacja, Serbia, Słowenia, Macedonia), aktów generalnych (Czechy, Macedonii) czy uproszczonych trybów postępowania (Węgry, Polska). Uzasadnia to przekonanie, że kierunek tych zmian wyznacza obecnie potrzeba uproszczenia postępowania administracyjnego i zwiększenia jego efektywności, jednak bez uszczerbku dla ochrony praw jednostki.

Agnieszka Krawczyk, dr hab., prof. UŁ, jest kierownikiem Zakładu Postępowania Administracyjnego Porównawczego w Katedrze Postępowania Administracyjnego na Wydziale Prawa i Administracji Uniwersytetu Łódzkiego, sędzią Wojewódzkiego Sądu Administracyjnego w Warszawie, autorką wielu publikacji naukowych z zakresu postępowania administracyjnego i sądowej kontroli administracji. Jej zainteresowania koncentrują się wokół problematyki postępowania administracyjnego krajów niemieckojęzycznych oraz państw Europy Środkowo-Wschodniej. Członek zespołu ekspertów do spraw reformy prawa o postępowaniu administracyjnym (2012-2016). 



\section{Chapter XIII}

\section{ReNEUAL's Model Rules in the Light of the "Common Core" of European Administrative Law*}

Giacinto della Cananea

Full Professor of Administrative Law

The Law School of the Bocconi University, Milan

gdcananea@gmail.com

(iD https://orcid.org/0000-0002-2062-6479

\section{Introduction}

Although administrative law is much younger - both as a part of legal systems and as an academic field - than private law, its history is far too rich and diverse, as it reflects history and culture, to be captured here and no attempt will be made to do so. However, a brief background can be helpful, on the one hand, to give and idea about the two main schools of thought that exist in this field and, on the other hand, to simply shed some light on the more important developments relating to the evolution of administrative law in Europe. This will provide the basis for a discussion about the current state of the law that governs the administrative procedure of the EU and the debate about its codification.

* Contribution to the volume edited by prof. Zbigniew Kmieciak, 19 May 2020. This piece is based on the comparative research funded by the European Research Council (grant agreement no. 694697 - CoCEAL). 


\section{Two Competing Visions of Administrative Law}

There is variety of opinion about the nature and purposes of administrative law. This is not surprising, because the differing opinions reflect important value judgments about social and political issues. ${ }^{1}$ But what matters for our purposes here is another significant difference of opinion that has characterized administrative and public law. It is the difference between the vision that considers administrative law as a sort of national enclave and the vision that considers it as one of most important manifestations of the new world that has emerged after 1789. It is clear that the choice of a particular conception of public law, as distinct if not wholly separated from private law, will play a role. However, what is of more immediate concern is that there have been significant differences of opinion within administrative law, viewed as an academic field, with regard to the relevance and significance of national cultures. It ought to be stated at the outset that these visions are not of interest only for theorists, because that may have, and have had, an impact on legal realities, in various ways. For example, the provision laid down by the Treaty of Rome concerning the non-contractual liability of the European Community reflects the idea that there are general principles of law that are, at least to a certain extent, common to a plurality of legal orders. ${ }^{2}$

\subsection{Public law as a national enclave}

At the roots of the view according to which the public law of each State should be regarded as a national enclave there is an important theory about the law tout court. Montesquieu may be regarded as the first great comparative lawyer who emphasized that, instead of being determined by some abstract principles or axioms, the rules of law generally differ from one country to another. We must, however, push further if we are to understand how Montesquieu intended national peculiarities. It is important to understand that he did not rule out the possibility to identify general principles that were more or less the same ("invariable laws"). ${ }^{3}$ Nor did he hide his opinion that certain principles or standards were better than others, as he argued with regard to separation of powers and the maxim audi alteram partem. ${ }^{4}$

One century later, it was the German lawyer von Savigny who argued that the law is a social artifact. Hence the claim that all laws, as human products, must be

1 M. Hauriou, Principes de droit public (1910), Paris 2010, p. 20; J. Rivero, Droit administratif (1960), Paris 2016, p. 17; M. Loughlin, Public Law and Political Theory, Oxford 1992.

2 See $\S 3$.

3 Montesquieu, De l'esprit des lois (1748), Paris 1979, p. 125 (“l'homme [...] est [...] gouverné par des lois invariables").

4 Ibidem, p. 294. 
seen as reflecting the spirit (Geist) of the people (Volk) from which they sprung. Accordingly, laws were inevitably related to the customs, beliefs and values of a particular people. This approach had undoubtedly the merit to warn against the naïve belief that the legislators may easily provide the solutions to problems by general rules not immediately growing out of national traditions, as it happened in Germany during the Napoleonic period. ${ }^{5}$ However, it was not immune from weaknesses. One of them was the overemphasis put on the full autonomy of the State, of each State, in regulating its own sphere. Another was Savigny's clear-cut distinction between private law and public law. While the former was considered as a systematic product, corresponding to the needs of economy and society, the latter was considered as much less systematic, due to the influence of politics. ${ }^{6}$ It is in this context that we should read Savigny's assertion that only Roman private law had become part of German private law, in contrast with Roman public law. ${ }^{7}$ This was a "surprising affirmation", according to Michael Stollais, the author of a path-breaking history of public law in Germany. ${ }^{8}$ For true, not all Roman public law could be transposed to German legal systems.

Whatever the intrinsic soundness of this approach, we may judge by its extreme consequences, for the Victorian constitutionalist Dicey brought it to an extreme. This approach emerges clearly in the following two sentences:

The true nature of the rule of law as it exists in England will be illustrated by contrast with the idea of droit administratif, [...] which prevails in many continental countries. ${ }^{9}$

In many continental countries, and notably in France, there exists a scheme of administrative law - known to Frenchmen as droit administrative - which rests on ideas foreign to the fundamental assumptions of our English common law, and especially to that we have termed the rule of law. This opposition is specially apparent in the protection given in foreign countries to servants of the State. ${ }^{10}$

It was this concept of public law that provided the basis for Dicey's claim that the English Constitution was not only different from those of continental countries,

5 F.C. Savigny, Vom Beruf unserer Zeit für Gesetzgebung und Rechtswissenschaft, Heidelberg 1814.

6 A related issue, that cannot adequately be dealt with here is whether the difference between Roman private law and public law, depended on the fact that the latter was less systematic, like that of England, as argued by H.E. Yntema, Roman Law and Its Influence on Western Civilization, "Cornell Law Quarterly" 1949, no. 35, p. 78.

7 F.C. Savigny, System des Heutigen Romisches Recht, Berlin 1840, p. 10. For further discussion, see C. Perelman, Logique juridique, Paris 1976, ch. 1.

8 M. Stollais, Geschichte des Offentlichen Rechts in Deutschland, Bd. I, 1600-1800, München 1998, p. 24. See also R. Michaels, Globalizing Savigny? The State in Savigny's Private International Law and the Challenges of Europeanization and Globalization, "Duke Law School Faculty Paper Series" 2005, no. 15, pp. 11-12 (pointing out that, for Savigny, public law was "political and thus unscientific").

9 A.V. Dicey, Introduction to the Study of the Law of the Constitution, (1st ed. 1885; London 1959, 10th ed.; hereinafter The Law of the Constitution), p. 204.

10 Ibidem, p. 205. 
but also better, thanks to the virtues of the rule of law. This claim was flawed, because Dicey misconceived the scope of administrative power that existed when he wrote the first edition of his treatise. ${ }^{11}$ Moreover, and more importantly, the French law to which he referred was that of the mid nineteenth century, which had changed profoundly. Notwithstanding these errors, Dicey's approach provided the basis for much later academic work, it significantly contributed to shaping a particular mentalité in the field of public law.

\subsection{Administrative law as a pillar of the new world}

Interestingly, Dicey himself, after exposing the antithesis between the public law system of France and England, placed it in a broader European perspective and thus somehow attenuated its importance. He observed that "the administrative law of France comes nearer than does the Verwaltungsrecht of Germany to the rule-of-law as understood by Englishmen". ${ }^{12}$

On this view, administrative laws are no longer premised on the axiom of national particularism. There is relative - as opposed to absolute - commonality and diversity, which is what makes comparison both interesting and fruitful. There is also the recognition that continental Europe is characterized by more commonality than there is with Britain.

It was precisely one of Dicey's preferred thinkers, Tocqueville, who brought this view to another extreme. In his masterpiece, he exposed the thesis of the continuity of French administrative institutions, notwithstanding the discontinuity of the political constitution..$^{13}$ In a later work, he pointed out that French administrative law was a prototype. ${ }^{14}$ It will become apparent that the approach presently under consideration was not based on the French superiority, but more simply on the fact that its institutions were the expression of collective needs. While the new world that was emerging after 1848 rejected Marxist theories of the State, it was based on the centrality of public services in areas such as education and health. Other administrative activities arose as a consequence of technological progress (railways and telegraph). Considered as a whole, the new activities of the State were not governed by systematic legislation, unlike in the field of private law. Administrative activities were largely governed by unwritten general principles and

11 P. Craig, Administrative Law, 5th ed., London 2005, p. 5.

12 A.v. Dicey, The Law of the Constitution..., p. 328, fn. 3.

13 A. de Tocqueville, L’Ancien régime et la Révolution (1856), a cura di J.P. Mayer, Paris 1967, libro I, capitolo IV).

14 A. de Tocqueville, Rapport fait à l'Académie des sciences morales et politiques sur le livre de M. Macarel, intitulé Cours de droit administratif, [in:] Euvres complètes d'Alexis de Tocqueville. Etudes économiques, politiques et littéraires par Alexis de Tocqueville (Lévy, 1866), p. 63. 
maxims (principes généraux et maximes absolues).$^{15}$ Tocqueville criticized some of those principles, in particular those concerning public liability and judicial review, for their negative impact on individual freedoms and rights. ${ }^{16}$ However, he foresaw that such principles would sooner or later be followed, if not imitated, by the other European peoples. The reason was not, he warned, the originality and superiority of the French legal tradition, but the conformity of those principles with the conditions of human beings in the new world. ${ }^{17}$ Administrative law would thus, by "natural" diffusion, spread elsewhere.

Perhaps the best proof of Tocqueville's prophecy was Otto Mayer's famous treatise of administrative law. ${ }^{18}$ Mayer did not merely point out that in France and Germany the principles of administrative law were largely the same. $\mathrm{He}$ argued that it was so because French administrative law had been adapted or imitated in the rest of Europe. This was a general statement the more precise implications of which will become clearer when considering the history of our administrative institutions.

\section{The General Principles of Administrative Law}

There are three reasons for combining history and legal comparison. First, it would be absurd to discuss the present state of administrative law, without an idea of how its scope and purposes evolved. As Paul Craig observed, "an understanding of the antecedents of our present set of administrative institutions is important"19 because it enables us to look at them dynamically. Second, both history and legal comparison reveal the contingency and relativity of the solutions - principles, institutions, and decisions - that legal systems use to solve the problems that daily arise. Thirdly, and more importantly for our purposes here, when considering the importance of both common and distinctive traits between national legal systems, we must have a sense of their relative weight and interaction. Of course, the 20th century may well have produced novel problems and solutions and so does the 21 st century. With this caveat, two legally developments will be considered; that

15 Ibidem, p. 66.

16 Ibidem, p. 68.

17 Ibidem, p. 71 ("notre droit administratif deviendra graduellement celui du monde civilisé, [...] grâce à sa conformité avec la condition des hommes de notre temps").

18 O. Mayer, Deutsches Verwaltungsrecht (1896), translated into French by the author Le droit administratif allemand, Paris 1904. For a similar remark, see M. Fromont, Droit administratif des Pays européens, Paris 2006, p. 11 (holding that continental countries were deeply influenced by the Napoleonic model).

19 P. Craig, Administrative Law..., p. 47. 
is, the judicial determination of the general principles of law between the last decade of the 19th century and the first decade of the 20th and the spread of codifications of administrative procedure after 1925. In the first case, the outcome of a recent comparative research will be illustrated. ${ }^{20}$ In the other case, few introductory remarks will be made.

\subsection{The judicial determination of general principles}

As soon as we compare our administrative institutions with those of private law within continental, a sharp difference soon becomes evident. The systematic and wideranging civil codes regulated the conduct of private individuals. Napoleon adopted the Code civil des Français in 1804, and it was directly applied in several within several other countries. The other great code of the epoch was the Austrian one, adopted in 1811. Several other countries used these codes as a source of inspiration for their own codes, including the Netherlands (1838), Italy (1865) and Portugal (1867). The German code was enacted in 1900 and it, too, had a wide influence abroad. ${ }^{21}$

Administrative institutions were instead created and grew in a somewhat messy manner. They were used to deal with particular problems, without any architect's design. For example, the French Conseil d'État, by far the most powerful administrative court of Europe, had no such thing as a linear evolution across time, but passed through both progresses and regresses. A fundamental change occurred in 1872 , with the shift from justice retenue to justice déléguéee. It was precisely during those years that several German States (Baden in 1867, Prussian in 1872), but not all of them, begun to create their administrative courts, followed by the Austrian Empire in 1875 and Italy in 1890. The last case is particularly interesting for our purposes here, because it shows, first, that the reform of 1890 reversed the choice made in 1865 in favour of a judicial review administered by ordinary courts and, second, that for a certain period of time little thought was given to the nature of the new dispute resolution panel created within the Italian Council of State. ${ }^{22}$ Only at

20 See Administrative Justice: Fin de Siècle, eds. G. della Cananea, S. Mannoni, Oxford 2020, forthcoming.

21 On the debate that preceded and followed the spread of codes in civil law countries in the XIX century, see R.C. Van Caenegem, European Law in the Past and the Future, Cambridge 2002. As will be apparent from the reasoning that is advanced in the text, the word "principles" is not used here to designate the abstract principles of a subject, but the fundamental norms of the legal order, or of a part of it, as distinct from both "policies" and "rules": for further discussion, see C. Harlow, Changing the Mindset: the Place of Theory in English Administrative Law, "Oxford Journal of Legal Studies" 1994, vol. 14, p. 419.

22 For an accurate analysis, see F.G. Scoca, Administrative Justice in Italy: Origins and Evolution, “Italian Journal of Public Law" 2009, vol. 2, p. 118, www.ijpl.eu (accessed: 14.05.2020). 
a later stage did several factors, including the holding of public hearings that were considered as judicial in nature and the ability to make final and legally enforceable decisions, determine the recognition that the panel was a court.

Despite these differences, the reasons for the creation of administrative courts were largely the same. Three arguments that emerged during that debate will be briefly mentioned here. The first was separation of powers, in the continental variant. Unlike in Britain, in France and other countries many thoughts that the ordinary courts had not to interfere with the executive branch. ${ }^{23}$ The second argument was expertise, because administrative courts were not staffed by "generalist" judges, but by experts of public administrations. Thirdly, with regard to the protection of relevant interests, there were two sides of the coin. Sometime, there was a belief that ordinary courts were unwilling to recognize individual interests different from traditional rights of ownership and trade. But there was a more widespread idea that the ordinary courts could not be sympathetic to the protection of the substantive interests that new legislation recognized and protected, for example with regard to limitation and expropriation of private ownership with a view to the protection from floods and the building of railways, respectively.

These differing reasons had variable force in the institutional context of that period. What is more relevant for our purposes here is that those administrative courts worked on the basis of few and very concise legislative provisions. Once again, French legal institutions were regarded as a model. For example, the grounds for bringing an action against an administrative act or measure (les cas douverture du recours), including lack of competence and misuse of powers, were clearly at the basis of the legislation issued in Italy in 1890, though it would be mistaken to assume that was uniformity and even that it was in the intent of lawmakers. Perhaps the most interesting and important legislative provision was that of the piece of legislation that in 1875 created the Austrian Administrative Court. The Act set out two grounds for annulling governmental measures; that is, their unlawfulness and their contrast with the essential forms of administrative procedure. ${ }^{24}$ The first ground served to ensure the respect of the decisions made by the legislature concerning both political and social choice, and thus the primacy of the legislative branch over the executive. As regarded the other ground, the phrase "essential forms of administrative procedure" ("wesentliche Formen des Administrativverfahrens") encapsulated two ideas: that there was a distinction between process and substance and that individuals had a right that the fundamental maxims of justice were respected in the exercise

23 See J.H. Merryman, The French Deviation, "American Journal of Comparative Law" 1996, vol. 44; p. 115; G. Bigot, Ce droit qu'on dit administratif, Paris 2015.

24 For a retrospective, see A. Ferrari Zumbini, Judicial Review of Administrative Action in the Austro-Hungarian Empire. The Formative Years (1890-1910), "Italian Journal of Public Law" 2018, vol. 10, www.ijpl.eu (accessed: 14.05.2020). In less recent literature, see H. Schambeck, The Development of Austrian Administrative Law, "Revue international de sciences administrative" 1962, p. 218 (asserting that the Rechstsstaat emerged only with the reform of 1867). 
of administrative powers. Of course, which maxims or standards were to be regarded as "essential" was left to the judicial determination and this explains why the jurisprudence of the Court rapidly gained importance.

More generally, everywhere the courts intended the limits of their intervention over the exercise of administrative discretion, in the sense that it was not their task to substitute judgment to the bodies of the executive branch. Despite the differing contexts, this was a common feature of both the legal systems that continued to rely on ordinary courts, such as Britain and Belgium, and the legal systems that created administrative courts, including France, Austria, Italy and the majority of German States. Another striking similarity regarded the judicial definition of the standards of administrative conduct. Despite the differences that existed between the Anglo-American concept of the rule of law and the German concept of Rechtsstaat and its French and Italian equivalents (État de droit, Stato di diritto), ${ }^{25}$ the courts exercised control to prevent misuses and abuses of power. So, for example, the courts intervened because a public administration had used its power for a purpose different from that allowed by legislation. Moreover, they increasingly intervened when public authorities, while exercising their powers for a purpose set out by legislation, had done so in a manner that was regarded as improper, unfair or irrational. Though the distinction was clear, it was not always easy to distinguish between legality and procedural fairness. But, for the latter the courts often used background theories of justice, such as natural justice in Britain ${ }^{26}$ and the "nature of the things" elsewhere, sometimes not without a reminiscence of natural law theories. The courts' role thus shifted towards ensuring principles of administrative propriety and fairness and, as Vittorio Emanuele Orlando (the main Italian public lawyer of that epoch) observed, such principles were largely the same. ${ }^{27}$

\subsection{Codifications: the spread of the Austrian model}

While the previous paragraph pointed out that the flourishing of administrative law was not, unlike in the field of private law, mainly the product of legislation, but of the courts, often in conjunction with learned legal experts such as Maurice Hauriou and Otto Mayer, this paragraph will consider a change that characterized the legal landscape since the end of the first quarter of the 20th century; that is, the codification of administrative procedure. It is fair to say at the outset that there had

25 See Otto Mayer's classic contrast between the Polizeistaat and the Rechtasstaat: Deutsches Verwaltungsrecht, 3rd ed., München 1924, I, p. 54.

26 See C. McCormick, Judicial Review of Administrative Action in the United Kingdom: the Status of Standards Between 1890 and 1910, "Italian Journal of Public Law" 2018, vol. 10, p. 49, www. ijpl.eu (accessed: 14.05.2020).

27 V.E. Orlando, Principii di diritto costituzionale, 3rd ed., Firenze 1894, p. 27. 
been some attempts during the previous century, mainly with regard to the judicial process concerning administrative action. Some of them failed, for example the project elaborated by Giandomenico Romagnosi in Italy. Others succeeded, such as the Spanish Act of 1889. But none of those initiatives had an importance comparable with the Austrian codification of 1925.

The reasons for the adoption of the first codification of administrative procedure must be considered historically. This requires inter-disciplinary analysis, with the contribution of lawyers, historians of law and other specialists. ${ }^{28}$ Some words are however warranted at this juncture. It is important to realize that several factors contributed to the codification. First, unlike the US Supreme Court, the Austrian Administrative Court could not invalidate primary legislation. In this respect, a change occurred much later. However, its jurisprudence obliged public authorities to make every effort to construe the implementation of legislation, and the exercise of discretion that it accorded to them, to be in conformity not only with traditional rights, as they were set out since 1867 , but also with process rights, concerning the conduct of administrative authorities. The Court took important steps in this direction, recognizing the right to be heard and the duty to give reasons.

Secondly, the Court inevitably judged individual cases, initially without even citing its precedents. It thus acted in a sort of micro perspective. A macro perspective was provided by academic works, in particular that of Friedrich Tezner. ${ }^{29}$ Such macro perspective looked to more systemic concerns and sought to address them. A more general impulse came from the Vienna legal school, of which Hans Kelsen was the leader and Adolf Merkl was the scholar more active in the field of administrative law. While earlier legal theories had focused on process rights only within the judicial process, Kelsen's school focused on procedures in relation to the discharge of other functions and powers. ${ }^{30}$ It thus favoured the spread of the idea that government should be able to respond to individual applicants.

Thirdly, after the fall of the Habsburg Empire, the Austrian Republic devoted considerable attention to the revision of the structures and processes of government. After the new Constitution entered into force in 1920, other legal instruments were issued, including the law governing administrative procedure, the law on administrative execution and another one concerning administrative sanctions. At least two features of the first Act deserve mentioning; that is, the framework and the general principles. The legislator proceeded on the assumption that the administration was part of the executive branch, but that their action could be regulated

28 Within COCEAL, there is a specific line of research, coordinated by professors Angela Ferrari Zumbini and Otto Pfersmann.

29 F. Tezner, Die rechtsbildende Funktion der österreichischen verwaltungsgerichtlichen Rechtsprechung: Die Rechtsquellen d. österreich. Verwaltungsrechtes, Wien 1925.

30 For this remark, see G. Isaac, La procedure administrative non contentieuse en France, Paris 1968, p. 91. 
similarly to the machinery of adjudication. Several consequences followed from this assumption, including the use of terms such as "parties" and "interest" and the possibility to avail of legal representatives. The principles set out by the law included impartiality, the right to be heard, the right to have an appeal against both procedural and substantive illegality. ${ }^{31}$

Seldom is public law legislation warmly received abroad and even imitated. This was the case of the Austrian codification of administrative procedure. For one of those invisible laws that govern the conduct of peoples, notwithstanding the dissolution of the Habsburg Empire, some of the peoples that had been included within it followed the new Austrian legislation. The governments of Czechoslovakia and Poland took up its principles and rules rapidly. ${ }^{32}$ Czechoslovakia issued a regulation on 13 January 1928, and Poland on 22 March 1928 (in the form of a presidential decree). Yugoslavia, too, adopted an Act two years later, 9 November 1930. The reasons underlying these choices will have to be analysed more accurately than is possible here, but what emerges from both academic works and official reports is that there was a common concern for ensuring the uniform interpretation and application of the law in the new multi-national polities. ${ }^{33}$ Moreover, and more importantly for our purposes here, according to several commentators, though some details differed, the general principles and even the structure of codification were the same ${ }^{34}$ For an apparent paradox, the Austrian codification, with its strong emphasis on the ideals of Rechtsstaat, has thus served as model for the peoples that had left the old multi-national polity.

For another apparent paradox, those peoples have continued to rely on the codification of administrative procedure after the change of their political regimes, when they fell more or less under the Soviet rule. In the same years, a codification of administrative procedure took place in Spain, too, under the authoritarian regime of Francisco Franco, while in Norway the firs project was discussed. In the following decades, not only Scandinavian States, but also other Western countries adopted administrative procedure acts. The use of codification by different types of political regimes revealed a plurality of goals, including ensuring the political control on the bureaucracy and improving administrative efficiency through routinized action, keeping administrative action within its

31 For further analysis, see R. Hernritt, La nouvelle procédure administrative autrichienne, "Annuaire Institut International de Droit Public" 1932, p. 251.

32 G. Langrod, Quelques problèmes de la procédure administrative non contentieuse en droit administratif comparé, "Revue international de sciences administratives" 1962, p. 5.

33 For this remark, see G. Isaac, La procedure administrative..., p. 109.

34 See G. Langrod, Note sur les principes du code de procédure administrative de Tchécoslovaquie, "Revue international de sciences administratives" 1956, p. 199 (noting the similarity); idem, Genèse et lignes directices de la procédure administrative non contentieuse en Pologne, ibidem, 1959, p. 399 ("une loi construite à l'instar du modèle autrichien"). 
limits and protecting individual rights. ${ }^{35}$ However, some general principles were largely the same, such as legality and impartiality. The questions that thus arose were whether those general principles meant the same thing and whether they produced similar effects. It is to the general principles that we must now turn, with an eye on European integration.

\subsection{General principles common to national legal systems}

The phrase "general principles of law" is not simply descriptive of the existence of legal norms or precepts which have a general scope of application and which operate differently from rules, in the sense that they do not apply in an "all or nothing" manner, but must be interpreted and weighed. It is a term of art, which serves to legitimate and guide administrators and judges. The Austrian legal order provides, once again, a fitting example, with the provision of the Civil Code (1811) that allowed judges, as a last resource, to take the principles of natural law into account. The Italian legal order provides another interesting example, though of a different type, because its Civil Code allows judges to refer only to the general principles of the legal order of the State, thus establishing a limit that has been removed in the field of administrative law by the legal provision which contains a renvoi to the principles of the legal order of the European Community (now Union). It is to these principles that we must now devote attention. As a first step, the concept of general principles in the Treaty of Rome will be explained, followed by an examination of the jurisprudence concerning some principles.

We have already seen that since the end of the 19th century the courts defined and refined some general principles that were largely the same and, in particular, regarded procedural rights as applicable in the dealings between individuals and public authorities. But one thing is to observe, descriptively, that such general principles were, as was the case, more or less the same, another thing was to affirm, prescriptively, that there were general principles common to various legal systems. Before 1945, the term "general principles" in the latter sense had already been used in the field of international law. The Permanent Court was authorized to refer to such principles. Likewise, its heir, the International Court of Justice was authorized by its Statute to apply not only customary law and treaties, but also "the general principles of law recognized by civilized nations" ${ }^{36}$ After the Nurnberg Trial, a further

35 For further analysis, see S. Cassese, Legislative Regulation of Adjudicative Procedures: an Introduction, "European Review of Public Law" 1993, p. 15; J. Barnes, El procedimiento administrativo en el derecho comparado, Madrid 1993. For a recent comparative analysis, see Codification of Administrative Procedure, ed. J.B. Auby, Brussels 2014.

36 Article 38(1), c) of the Statute of the ICJ, on which see B. Cheng, General Principles of Law as Applied by International Courts and Tribunals, Cambridge 1987 (considering the principles nemo judex in causa propria, audiatur et altera pars, as well as res judicata). On the question 
impulse was given to the use of general principles of law beyond national borders. European integration played a key role in this respect. While the standard account begins with the Treaty of Rome, in the light of the provision concerning non-contractual liability, this reflects the positivist viewpoint that still dominated the field in those years. We will, therefore, first, consider the choices made by the European Court of Justice in the early years of its jurisprudence. Next, we will describe the changes deriving from the Treaty of Rome. Finally, we will examine two rulings delivered by the Court in relation to two fundamental procedural requirements; that is, the right to be heard and the duty to give reasons.

It can be helpful to begin by clarifying that the ECJ has, ever since its origins, replicated some features of French administrative courts. It has exercised judicial review to prevent the misuse of discretionary powers, without substituting its judgment to the decisions taken by public authorities. This is confirmed by the grounds of action established by the treaties, which have included lack of competence, infringement of essential procedural requirement ("violation des formes substantielles"), misuse of power, and infringement of the treaty or any rule of law relating to its application. ${ }^{37}$ At the same time, precisely because its role is to ensure that the law is respected in the application of the treaties, ${ }^{38}$ the Court has not hesitated to use the general principles of law.

For this purpose, it has used the comparative method. It has done so, for example, in the well-known Algera case. In brief, several employees of the Common Assembly of the ECSC had brought an action against the decision by which the Assembly's General Secretariat had withdrawn some financial benefits initially conceded to them. Before deciding whether the administration had reasonably exercised the power of revoking or withdrawing such benefits, the Court had to ascertain whether this power existed, since neither the Treaty nor the specific regulation expressly provided. Faced with the problem of a lacuna of the legal system created by the Treaty, the Court resolved it in an ingenious way. It affirmed that "unless the Court is to deny justice, it is therefore obliged to solve the problem by reference to the rules acknowledged by the legislation, the learned writing and the case-law of the member countries". ${ }^{39}$ The following step of the Court's reasoning was to observe that "the revocability of an administrative measure vitiated by illegality is allowed in all Member States". As Jean Rivero finely noted, it was a "droit commun" that which was elaborated in the Europe of the Six with regard to the standards of legality. Rivero added that this elaboration was based on a deeper

whether national principles are considered as norms or facts, see G. Gaja, Dualism - a Review, [in:] New Perspectives on the Divide Between National and International Law, eds. J. Nijman, A. Nollkaemper, Oxford 2007, p. 52.

37 ESCS Treaty, Article 33; EEC Treaty, Article 173.

38 ESCS Treaty, Article 34; EEC Treaty, Article 164.

39 Joined cases 7/56, 3/57 to 7/57, Algera et al. v Common Assembly of the ECSC. 
unity of their legal systems. ${ }^{40}$ In other words, since the early years of European integration, the Court refused the positivist assumption that the "law" of which it had to ensure the respect coincided with the Treaty and the sources it had created. Rather, it worked on the assumption that a common legal substrate existed and that it could avail of it.

The Treaty of Rome was by no means a deviation from this assumption. Indeed, Article 215, that regarded the non-contractual liability of the institutions of the EC, ${ }^{41}$ implied not only the assumption that certain general principles of law common to national laws existed, but also the use of the comparative method for their individuation. That provision may be considered, therefore, more as a confirmation of the acquis than as an innovation. Nevertheless, there is a serious risk, if such a minimalist view were to be adopted, that our capacity to understand the emergence of a new perspective would be seriously undermined. In fact, the Court's interpretation and use of general principles common to the laws of the Member States went well beyond the provision concerning non-contractual liability. Its main bases was the general clause according to which its mission is to ensure the respect of the "law" tout court in the interpretation and application of the Treaty, as well as the reference made by the Treaty to the observance of any rule of law. ${ }^{42}$ In this way, the Court has identified a variety of principles concerning the exercise of power by public authorities, including legal certainty, the protection of legitimate expectations, and the principle of proportionality. Another group of common principles concerns the limits to the powers exercised by public authorities. Such common principles include fundamental rights, as they stem from national legal orders, as well as from the ECHR. For example, the Court has affirmed that

40 J. Rivero, Le problème de l'influence des droits internes sur la Cour de Justice de la Communauté Européenne du Charbon et de l'Acier, "Annuaire français de droit international" 1958, p. 265 ("un droit commun qui s'élabore dans l'Europe des Six en matière de contrôle de la légalité, traduction juridique d'une unité plus profonde, qui atteint l'ordre des rapports entre le pouvoir, le droit, et l'homme"). See also E. Stein, Uses, Misuses - and Nonuses of Comparative Law, "Northwestern University Law Review" 1977-1978, vol. 72, p. 206 (pointing out the growing number of legal transplants realized by Community law). See also J. Schwarze, Judicial Review of European Administrative Procedure, "Law and Contemporary Problems" 2005, vol. 68 , p. 85 (delineating the main principles of administrative procedure).

41 Article 215 (2), which is now reproduced by Article 340 (2) TFUE, provided that: "the Community shall, in accordance with the general principles common to the laws of the Member States, make good any damage caused by its institutions or by its servants in the performance of their duties". For further remarks, see W. van Gerven, The Emergence of a Common European Law in the Area of Tort Liability: the EC Contribution, [in:] Tort Liability of Public Authorities in Comparative Perspective, eds. D. Faigrieve, M. Andenas, J. Bell, London 2002, p. 125.

42 T. Koopmans, The Birth of European Law at the Cross-roads of Legal Traditions, "American Journal of Comparative Law"1991, p. 495. The fact that the ECJ has not simply interpreted, but created law has been recognized by some judges: see recently S. Papasavvas, La creation du droit par le juge de l'Union européenne, "European Review of Public Law” 2012, vol. 24, p. 167. 
the right to be heard in an administrative procedure, before a decision adversely affecting an individual or a firm is taken, is a feature of administrative law common to several European countries and is, therefore, a general principle of EU law. ${ }^{43}$ This encourages national courts to do the same, when reviewing the legality of national measures and practices implementing EU law.

For present purposes, there is no need to take a position about the instrumental or non-instrumental use that the ECJ has done of fundamental rights. ${ }^{44}$ What matters is, rather, first, that the Court's approach to public law has challenged the idée reçue of contrasting national traditions in this field and, second, that this approach has not only shaped the evolution of the public law of the EC, but that it has also influenced national legal orders. Consider, for example, the principle of proportionality. Historically, it is questionable whether this principle, which implies that the exercise of power must not impinge on rights more than it is necessary for the achievement of public goals, is only a German doctrinal construct or has some common elements with English and continental views about reasonableness. ${ }^{45}$ But there is no doubt that the test of proportionality is now frequently invoked before national courts. The courts thus have to determine the weight that must be given to the individual, collective, and public interests involved and this inevitably influences interests balancing.

\section{The Codification of Administrative Procedure in the EU}

It was said previously that all grants of power to public bodies have a political dimension, in the sense that they reflect the choices made about various political issues. This last section of the chapter will be principally concerned with the debate concerning the codification of the administrative procedure of the EU. The discussion will begin by briefly analysing the arguments used in favour and against codification between the adoption of the Treaty of Maastricht and entry into force of the Treaty of Lisbon

43 European Court of Justice, Case 17/74, Transocean Marine Paint Association v Commission [1974] § 15. For further analysis, see G. della Cananea, Due Process of Law Beyond the State. Requirements of Administrative Procedure, Oxford 2016.

44 For critical remarks, see J.H.H. Weiler, Eurocracy and Distrust: Some Questions Concerning the Role of the European Court of Justice in the Protection of Fundamental Human Rights within the Legal Order of the European Communities, "Washington \& Lee Review" 1986, vol. 61, p. 1103.

45 See A. Stone Sweet, H. Matthews, Proportionality Balancing and Global Constitutionalism. A Comparative and Global Approach, Oxford 2019. 
(2009). This will be followed by an examination of the new constitutional framework laid down by the latter Treaty. The argument that will be put forward is that, in the new framework, Article 298 TFEU lays down a constitutional duty to regulate procedure. The focus will then shift on how such provision may be implemented by way of the "Model Rules" elaborated by ReNEUAL, an independent network of scholars and practitioners. These "Model Rules", are based on current law in order to systematize, fill exising gaps, and also make innovative proposals for the fields where there are no clear rules for the protection of citizens and businesses. ${ }^{46}$

\subsection{The debate on codification: from Maastricht to Lisbon}

After the Single European Act (1984) and the adoption of the measures aiming at achieving the Single Market, both politicians and academics begun to raise the question whether the time was ripe for a codification of the administrative procedure of the EU, including both adjudication and rule-making. Several arguments were brought in favour of a codification. They met criticism on various grounds. ${ }^{47}$ Three of them will be considered here. The first was the need of a better legal framework in order to protect individuals and groups. The second was that, while lobbies discretely influenced the contents of EC legislation, citizens' participation was almost absent. The third was the need of a legislative codification, instead of leaving regulation to the courts.

The first argument combined both a general rationale of codification regulation of administrative procedures and a more specific one, concerning those of the EC. The general rationale is that codes, whichever their content be, are very useful means for limiting and structuring administrative discretion, in order to prevent it from degrading into arbitrariness. Once a legislative regulation is enacted, the conduct of administrations can be confronted with the standards previously adopted. Accordingly, the exercise of discretion, which is an inherent feature of administrative action, can be made accountable both to elected bodies and to the courts. A possible objection, often used in the French legal culture, was however that rules might be too rigid, that any code runs the risk of becoming a sort of corset paralysant. ${ }^{48}$ Interestingly, this argument has been used, more recently, by the Commission in order to justify the status quo.

46 See ReNEUAL Model Rules on EU Administrative Procedure, eds. P. Craig, H. Hofmann, J.P. Schneider, J. Ziller, Oxford 2017. They are also published in several other languages: see ReNEAULS' website: www.reneual.eu (accessed: 14.05.2020).

47 For the case for codification, see G. della Cananea, From Judges to Legislators? The Codification of EC Administrative procedures in the Field of State Aid, "Rivista italiana di diritto pubblico comunitario" 1995, p. 967. For the case against it, see C. Harlow, Codification of EC Administrative Procedures? Fitting the Foot to the Shoe or the Shoe to the Feet?, "European Law Review" 1996, vol. 2, p. 331.

48 G. Isaac, La procedure administrative... 
The second argument focused on the fact that, while the general principles recognized by the ECJ included the right to be heard, citizens' participation was not recognized and protected. More generally, while the courts are often willing to protect individual rights, they tend to overlook collective interests. For example, the publicity of administrative activities is regarded instrumentally and indirectly, to the extent to which it is meaningful for judicial review. ${ }^{49}$ Only if duties of consultation or real participatory rights are established, so the argument goes, may collective interests obtain a more acceptable level of protection. This argument has further ramification, to the extent to which it leads to prefer the notice and comment ideal-type of administrative procedure to those based on the paradigm of trial.

Finally, whether or not a less individually biased type of regulation of administrative procedures was preferable, the question arose whether such regulation had be provided either by legislators or by the courts. Many observers in different periods of time and institutional frameworks had already argued that judicial review was, and still is, inherently limited. It comes late, it is not stable and it is expensive both for individuals who wish to challenge an administrative act and for the society as a whole, which would benefit from rules of general application..$^{50}$ The advocates of judge-made law replied that the courts may provide a more flexible adjustment, without the unnecessary uniformity which is an inevitable consequence of legislative regulation.

The counter-argument based on flexibility could, however, determine a reasonable preference for legislation limited to broad principles, in order to leave a certain leeway to the courts. The Italian APA, for example, shows that they have been ready to use some legislative clauses, especially as far as due process and access to information are concerned. This shows that a more accurate analysis of existing codification is required, before we make an attempt to draw advice from it, apart from Hume's caveat against any attempt to turn an is into an ought.

Another counter-argument was based on the nature of the EC. Whilst accepting in principle that the intervention of parliaments enhances democratic legitimacy, the counter-argument was that this was not the case in the EC. The reason was that legislative authority was shared between the European Parliament and the Council of ministers. It was wrong, however, to evaluate the Union on the basis of the standards elaborated within national political systems.

At this stage of the analysis, it should be clear that the debate had many facets. Administrative action was increasingly different and more complex than it had been for some decades. Process rights had been enhanced in certain areas, but not in all. The courts were facing new challenges as a result of the legislation aiming

49 Ibidem, p. 72.

50 S. Cassese, Legislative Regulation..., p. 17. 
at protecting collective interests, such as a clean environment. ${ }^{51}$ The very success of the arguments in favour and again a codification of administrative procedure could not, and did not, be dependent only on the intrinsic soundness of those arguments. It was for political authorities to face old and new issues and decide whether or not legislation was needed and, if so, whether it ought to be defined either in broad, open textured terms or in a detailed manner.

\subsection{After Lisbon: a constitutional duty to regulate administrative procedure}

The situation just described has changed after 2009, in the new constitutional settlement of the EU. ${ }^{52}$ Limits of space do not permit an analysis of the background; that is, the evolution of the Union's constitutional order. Suffice it to mention that the Lisbon Treaty has recognized three changes that are particularly relevant from the viewpoint of the theory of legal orders and, additionally, has laid down a new constitutional imperative to regulate the conduct of EU administrative authorities.

The three changes that are relevant and significant from the viewpoint of the theory of legal orders concern the Union's social element, its organization and its normative powers. ${ }^{53}$ First, the Treaty of Lisbon has not only reflected a much more differentiated membership than before, because of the accession of ten new Member States, many of which had changed their political regimes after the fall of the Berlin wall. It has also strengthened the Union's democratic dimension, as is showed by the provisions concerning participatory democracy. Last but not least, unlike the previous treaties, the Lisbon Treaty has given a new status to the Charter of fundamental rights of the EU, adopted at Nice in 2000. Article 6 (2) TEU gives to the Charter the same legal value of the treaties and it does so, significantly, in the context of a provision that recognizes the importance of both the European Convention on Human Rights and common constitutional traditions, as sources of rights. ${ }^{54}$ Secondly, it is precisely because the EU is a union of both States and peoples that the importance of the social element is recognized

51 On the Court's reluctance to give access to these interests, see C. Harlow, Towards a Theory of Access for the European Court of Justice, "Yearbook of European Law" 1992, vol. 12, p. 213.

52 On executive power prior to 2009, see D. Curtin, Executive Power of the European Union. Law, Practices, and the Living Constitution, Oxford 2009. On the Lisbon Treaty's new settlement, see P. Craig, The Lisbon Treaty: Law, Politics, and Treaty Reform, Oxford 2013 (revised edition).

53 Santi Romano's masterpiece, L'ordinamento giuridico (1946, 2nd ed.) has been eventually translated into English: see The Legal Order, London 2017.

54 On the Charter, as it was initially delineated, see A. von Bogdandy, The European Union as a Human Right Organization? Human Rights and the Core of the European Union, "Common Market Law Review" 2000, vol. 37, p. 1307. 
in the framework of the weight that is accorded to majorities in decision-making processes. ${ }^{55}$ Moreover, the European administration, once centred on the Commission, is now characterized by a multiplicity of agencies. ${ }^{56}$ Thirdly, the normative powers of the Union have been better defined, with a distinction between legislative, delegated and implementing acts (Article 290-1 TFEU), which, considered as a whole, have a lower rank than treaty provisions, general principles of law, and other agreements.

Considered as a whole, these remarks should make clear that it is perfectly possible to proffer systematic interpretations of the treaties based upon democracy and rights. It might for example be argued that we should foster fundamental rights, in the sense that without adequate procedural propriety and fairness those rights would be part of law in the books, as distinct from law in action. The "Model Rules" elaborated by ReNEUAL develop this argument by generalizing some existing institutions and proposing new ones for both individual decisions and contracts. ${ }^{57} \mathrm{It}$ might, alternatively, be argued that if the EU has to be a participatory democracy, this does not concern only its political institutions, but also its administration. In this respect, the "Model Rules" go well beyond existing legal provisions. They delineate a general duty to consult the holders of the interests that can be affected by rulemaking, in its varieties of forms. Coherently with such duty to consult, the "Model Rules" require any rulemaking authority to supply sufficient information to those being consulted, in order to enable them to submit their observations and proposals..$^{58}$ There are undoubtedly connections between these lines of reasoning and the values upon which the EU is founded according to Article 4 TEU. The virtues of these arguments may, however, be contested as will the degree to which they are consonant with the way in which the social groups that constitute the EU are ordered.

This explains why the focus is on a more specific argument, based on Article 298 TFEU, which concerns the Union's administration. Unlike most provisions of the treaties, Article 298 has been introduced by the Lisbon Treaty. ${ }^{59}$ It has an innova-

55 W. Van Gerwen, The European Union: A Polity of States and Peoples, Stanford 2005.

56 For a recent analysis of EU agencies, see EU Executive Governance: Agencies and Procedures, eds. M. Conticelli, M. De Bellis, G. della Cananea, Torino 2019.

57 Consider, for example, MR III-25 (2) on consultation of the interested public, according to which the "public authority may choose to consult through a public hearing. This hearing must be notified through public announcement, which must be posted on an official website... A public hearing must be held in sufficient time before the decision is made".

58 Consider MR II-4 (3-4) on consultation and participation, according to which the EU authority must invite the persons who likely to be affected by the new rules to make their comments and such "comments are made public in a way that allows public exchange of views".

59 Article 298 TFEU provides that: " 1 . In carrying out their missions, the institutions, bodies, offices and agencies of the Union shall have the support of an open, efficient and independent European administration. 2. In compliance with the Staff Regulations and the Conditions of Employment adopted on the basis of Article 336, the European Parliament and the Council, 
tive character, moreover, because it refers for the first time to the European administration, considered as a whole. Although such provision has not immediately received attention by many commentators, it is potentially very important. ${ }^{60}$ It has two indents, the first of which determines the principles guiding the European administration, while the second individuates the means for implementing such principles and thus making them effective. For the achievement of the goals of the EU, its institutions avail of a European administration that must be independent, efficient and open. The instruments for assuring that the European administration conforms its action to such values or principles are essentially normative, although it could be observed that a reconsideration of certain practices and more generally of the culture of the European administration is required. That said, the second ident of Article 298 accords the primary responsibility on the Council and Parliament, which together constitute the dual legislator of the EU. They are entrusted with the power to enact regulations, though providing little detail as to how this should be done and particularly as to their contents.

Three comments look appropriate at this stage of our analysis. The first is normative in character and concerns the broad scope of application of Article 298 and the vision of the European administration that it encapsulates. The provision of the Treaty does not refer only to the institutions and bodies of the EU whose administrative units have, with the notable exception of the Commission, simply the role of a secretariat, without powers on public and private bodies outside. It also refers, for the first time in a Treaty provision, to the agencies of the EU.

The second comment is teleological, because it regards the substantive goals that Article 298 aim at achieving. Whether or not, the choice to put openness first, followed by efficiency and independence indicates a priority, if not a hierarchy, the last one is a reiteration of the requisite of independence set out since the Treaties of Paris and Rome. Both openness and efficiency, instead, have a more innovative character. Whether the drafters of the Treaty were aware of the growing popular dissatisfaction with the performance of the $\mathrm{EU}$, is an interesting question, which deserves autonomous treatment.

The third comment concerns the consequences that follow from Article 298 TFEU, considered as a whole. This provision does not simply authorize the European Parliament and the Council to set out regulations. Its language is mandatory ("shall establish provisions") and builds a clear relationship between ends and means. ${ }^{61}$ As a result of this, to enable the Parliament and the Council to legislate, the Commission is re-

acting by means of regulations in accordance with the ordinary legislative procedure, shall establish provisions to that end".

60 See P. Craig, A General Law on Administrative Procedure, Legislative Competence and Judicial Competence, "European Public Law" 2013, vol. 19, p. 503.

61 For further discussion, see J. Ziller, Is a a Law of Administrative Procedure for the European Union Necessary?, "Rivista italiana di diritto pubblico comunitario" 2011, p. 699. 
quired to submit proposals "to this end", to borrow the words of Article 298 (2). Notwithstanding the resolutions presented by the Parliament under Article 225 TFEU, the Commission refrained from so doing on grounds that it was not necessary. ${ }^{62}$ This was clearly a political decision. Whatever its intrinsic soundness, whether or not it was a politically legitimate decision, it was for that Parliament to judge, as will be for the new Parliament, which took office in 2019.

\subsection{Three pathways for the "Model Rules"}

Notwithstanding the Commission's refusal to elaborate a proposal, whether or not based on the "Model Rules", a regulation or a set of regulations under Article 298 remains the optimal way to regulate the administrative procedure of the EU. However, two other pathways will be briefly considered, at EU level, but through the courts, and at national level, through either legislation or government guidance.

The advantages of a regulation issued under Article 298 TFEU can be appreciated at three levels, axiological, institutional and operational. At the axiological level, the "Model Rules" seek to "address how the constitutional values of the Union can be best translated into rules on administrative procedure covering the non-legislative implementation of EU law and policies". ${ }^{63}$ They thus have the potential of fostering compliance with the general principles of EU law, for which there is a concise renvoi in the preamble. Two aspects, in particular, may be mentioned. First, the duty to consult has a wide significance. It allows those outside the machinery of government to play some role in the shaping of policy, which is increasingly important at EU level, because in many areas essential policy decisions are taken by EU institutions and agencies. Second, precisely because there is an increasing amount of administrative work that is carried out by EU and national officers, there is the necessity to ensure bureaucratic rationality, in the logic of sound administration. Institutionally, as observed earlier, there is a precise duty to regulate the action of the $\mathrm{EU}$ administration. There is a corresponding duty for EU authorities and agencies to follow the general rules issued by the Union's political institutions. Operationally, the "Model Rules" would work as a "boilerplate" to be supplemented with sector specific norms in the various areas. On the one hand, adequate flexibility would thus be provided by the lex generalis - lex specialis relationship. On the other hand, sector specific norms would have to be interpreted in coherence with the general rules. ${ }^{64}$

62 See the answer given by the Commission's Vice-President Dombrovskis to a Parliament question on the law of administrative procedure of the EU.

63 ReNEAUL's Model Rules, Book I, § 14.

64 See ReNEAUL's Model Rules, Book I-2 (2). 
In the absence of a legislation implementing the duty set out by Article 298, we may wonder whether EU courts can use the "Model Rules". Several commentators have argued that, with the exception of few provisions of the treaties, the principles of EU administrative law have been developed by the courts. They are the creation of the ECJ, in particular. Following this line of reasoning, it would be for the courts to consider whether the "Model Rules" may be helpful when the courts decide on the appropriate procedural and substantive principles that public authorities must respect. Agency action that infringes the general principles of EU law, as specified by the "Model Rules", would thus be unlawful. There is, in this sense, nothing odd or strange about a set of rules that are explicitly derived from the general principles of EU administrative law to be used when one of those principles is invoked before a EU court. This is indeed the paradigm when advocates generals cite the jurisprudence of other courts or the works of learned experts. It has indeed been the case in the opinion delivered by AG Campos Sanchez-Bordona in a recent case concerning an EU mixed administrative procedure; that is, a procedure in which both EU and national authorities intervene. ${ }^{65}$ Of course, it could be objected that "einmal ist keinmal". However, AG Kokott, too, has referred to the "Model Rules" in another context, that of the contracts concluded by the EU administration. As a starting point, it ought to be said that the lower court, faced with the applicant's claim that the EU administration could not unilaterally recover debts under a contract, had not contested the validity of the applicant's assertion based on the principles governing contracts, but had clarified that the administration may have the power do so, under specific norms. ${ }^{66}$ In other words, far from contesting the lex generalis, the Court had found a lex specialis. In her opinion on the appeal, AG Kokott used a different approach. She observed that the Member States have different ideas concerning the administration's power to act as a public authority and, thus, terminate a contract. ${ }^{67}$ As a result of this, she argued that "the Commission's power to adopt enforcement decisions in order to recover debts arising under a contract also cannot be rejected by reference to general principles of contract law". The reason is, and this is what matters more for our purposes here, that "such principles simply do not apply in such a general way to contracts of public authorities". ${ }^{68}$ It is in this sense that another principle, allowing the administration to act unilaterally, emerges. Only time will tell the Court of Justice decides to follow her AG and whether other references will be made to the "Model Rules".

65 Opinion of AG Campos Sanchez-Bordona delivered on 27 June 2018, in case C-219/17, Berlusconi v. IVASS, fn. 21.

66 General Court, case T-644/14, ADR Center v. European Commission, § 200.

67 Opinion of AG Kokott delivered on 7 November 2019, case C-584/17 P, ADR Center v. European Commission, § 82.

68 Opinion of AG Kokott delivered on 7 November 2019, case C-584/17 P, ADR Center v. European Commission, $\S 84$ (the reference to the "Model Rules" can be found in fn. 65). 
Another scenario builds upon the Member States in the following way. The "Model Rules" are made of principles and rules applicable to the various forms in which the administrative action of the institutions, bodies and agencies of the EU takes place. The conduct of national authorities remains governed by national standards, not within the scope of the "Model Rules", to which national law may however refer. The reasons is that national authorities must apply the general principles of EU law when they act within its scope, but nothing prevents them from unilaterally appliying it outside its scope. They may wish to do so, for example, in order to prevent the inequality of treatment that would derive from treating like cases differently only because one falls under EU law and another does not. Alternatively, they may wish to do so because EU law is regarded as being more satisfactory than national law. A Member State may either draw inspiration from the "Model Rules" or formally refer to them with a view to reforming its procedural rules or adopting new ones. ${ }^{69}$ The possibility of collective action should also be considered, for the sake of completeness. A group of Member States, for example in the framework of an enhanced cooperation, may decide to do so for non-instrumental or instrumental reasons. Those States may want to make every effort to construe their legislation, as well as to exercise their administrative discretion, in conformity with the fundamental rights recognized by the EU charter and coherently, in order to avoid unjustified differences. Or, in an instrumental perspective, they may want to improve their cooperation in the discharge of activities of common concern. They may thus use the "Model Rules"; that is, f the standards set out by Books V and VI concerning mutual assistance and information management, respectively.

A final caveat is required. The conjecture just made should not be considered as infirming the validity of the remark previously made; that is, a regulation issued under Article 298 TFEU is the best option for achieving the goals of openness and transparency. However, we should be mindful of the difficulties that the adoption of such regulation can pose in a EU of twenty-seven Member States, with differing administrative cultures. This is but an aspect of a broader issue. It is precisely because the EU was increasingly differentiated that the provisions on enhanced cooperation were included in the Nice Treaty and, a fortiori after the new enlargement, that those provisions were later amended by the Lisbon Treaty. ${ }^{70}$ It should be recognized that any approach of the kind under examination will require some choice as to what are to count either as fundamental rights or as key standards of administrative cooperation. This choice will reflect assumptions or choices as to the importance of those rights in some societies or as to the meaning to be

69 I have developed this line of reasoning elsewhere: see G. della Cananea, A Law on EU Administrative Procedures: Implications for National Legal Orders, [in:] Current Issues of the National and EU Administrative Procedures (the RENEUAL Model Rules), eds. G. Balazs, L. Berkès, A. Varga, Budapest 2015, p. 283.

70 For further discussion, see the last chapter of P. Craig, The Lisbon Treaty... 
ascribed to certain standards of good administration. This will not be without consequences for the other partners. This is unavoidable. It is in the logic of enhanced cooperation. Whether this logic will prevail, is another question, which deserves autonomous treatment.

Giacinto della Cananea, full professor of administrative law at the Bocconi University (Milan). In 2016, he has been awarded an advanced grant by the ERC for his comparative research on the Common Core of European Administrative Laws. In 2018 he has been awarded, on behalf of ReNEUAL, the first Spinelli prize for outreach, for the work on the codification of the administrative procedures of the EU. His last monograph is Due Process of Law Beyond the State (Oxford University Press 2017). His last edited book is the Research Handbook of European Administrative Law (co-authored with Carol Harlow and Paivi Leino; Hart 2017). Since 2009, he is co-editor of "Italian Journal of Public Law". 



\section{Rozdział XIII}

\section{Reguły modelowe ReNEUAL w świetle wspólnych zasad europejskiego prawa administracyjnego*}

Giacinto della Cananea, profesor zwyczajny prawa administracyjnego

Wydział Prawa Uniwersytetu Bocconi w Mediolanie

gdcananea@gmail.com

(iD) https://orcid.org/0000-0002-2062-6479

\section{Wprowadzenie}

Chociaż prawo administracyjne jest znacznie młodsze od prawa prywatnego, jego historia jest zdecydowanie bogatsza i bardziej różnorodna. O drodze ewolucji tej części porządku prawnego przesądziły zachodzące w szybkim tempie przemiany historyczne i kulturowe. Nie to zagadnienie jest celem niniejszego opracowania, ale krótki zarys tła dokonujących się zmian może okazać się przydatny dla ukazania dwóch głównych, istniejących w tym przedmiocie nurtów doktrynalnych oraz rzucić nieco światła na ważniejsze fazy ewolucji prawa administracyjnego w Europie. To właśnie stanowić będzie przedmiot rozważań o aktualnym stanie prawa o postępowaniu administracyjnym w Unii Europejskiej i jego kodyfikacji.

* Wkład do tomu redagowanego przez prof. Z. Kmieciaka, 19 maja 2020 r. Ten rozdział zostat oparty na badaniach porównawczych ufundowanych przez Europejską Radę ds. Badań Naukowych (numer zgody na przyznanie grantu 694697 - CoCEAL). 


\section{Dwie konkurencyjne wizje prawa administracyjnego}

Zdania na temat charakteru i celów prawa administracyjnego są podzielone, co nie może zaskakiwać, jeżeli weźmiemy pod uwagę, że opinie te odzwierciedlają różne poglądy na temat kwestii społecznych i politycznych ${ }^{1}$. To, co ma znaczenie dla celu tego opracowania, to inna, znamienna różnica stanowisk, charakteryzująca prawo administracyjne i prawo publiczne. Jest nią mianowicie dystynkcja pomiędzy koncepcją uznającą prawo administracyjne za rodzaj narodowej enklawy a podejściem zakładającym, że prawo administracyjne stanowi jedne z najważniejszych zjawisk nowego świata zrodzonego po 1789 r. Jest oczywiste, że pewną rolę odgrywa opowiedzenie się za określoną koncepcją prawa publicznego, wyodrębnionego, jeżeli nie całkowicie odseparowanego od prawa prywatnego. Jednakże, co bardziej znaczące, zachodzą poważne różnice zdań w nauce prawa administracyjnego co do roli odgrywanej przez tradycje narodowe. Należy zaznaczyć, że poglądy te są interesujące nie tylko dla teoretyków prawa, ponieważ mogą one mieć i miały różnorodny wpływ na rzeczywistość prawną. Na przykład przepis Traktatu Rzymskiego dotyczący odpowiedzialności pozaumownej Wspólnoty Europejskiej dowodzi istnienia ogólnych zasad prawa, które - przynajmniej w pewnym stopniu - są wspólne wielu porządkom prawnym².

\subsection{Prawo publiczne jako enklawa narodowa}

U źródeł poglądu, zgodnie z którym prawo publiczne każdego państwa należy uznać za enklawę krajową, nie leży nic innego jak doktryna prawna. Monteskiusza można byłoby uznać za pierwszego wielkiego komparatystę. Zauważył on różnice pomiędzy unormowaniami poszczególnych systemów, które nie są zdeterminowane zasadami ogólnymi czy aksjomatami, lecz tylko „regułami”. Musimy jednakże pójść dalej, jeżeli mamy zrozumieć to, w jaki sposób Monteskiusz rozumiał osobliwości systemów państw narodowych. Ważne jest to, by wiedzieć, że dopuszczał on możliwość wskazania zasad ogólnych czy standardów, które byłyby mniej więcej takie same („niezmienne prawa”) ${ }^{3}$. Nie ukrywał też swojej opinii, zgodnie z którą pewne zasady czy standardy były lepsze niż inne, ponieważ rozważania swoje prowadził w odniesieniu do zasad podziału władzy i audi alteram partem ${ }^{4}$.

1 M. Hauriou, Principes de droit public (1910), Paris 2010, s. 20; J. Rivero, Droit administratif (1960), Paris 2016, s. 17; M. Loughlin, Public Law and Political Theory, Oxford 1992.

2 Zob. pkt 3.

3 Montesquieu, De l'esprit des lois (1748), Paris 1979, s. 125 („,'homme [...] est [...] gouverné par des lois invariables").

4 Ibidem, s. 294. 
Stulecie później to niemiecki prawnik - von Savigny - opisał prawo jako zjawisko społeczne, wskazując, że wszystkie regulacje prawne, jako dzieło aktywności ludzkiej, muszą być postrzegane jako odzwierciedlenie ducha (Geist) narodu, z którego one wyrastają. Wobec tego, prawo było nieodłącznie związane ze zwyczajami, poglądami i wartościami określonej społeczności. To podejście miało niewątpliwie przestrzegać przed naiwną wiarą, że ustawodawcy mogą w prosty sposób zagwarantować rozwiązanie problemów za pomocą norm generalnych, niekoniecznie wywodzących się $\mathrm{z}$ tradycji narodowych, jak to miało miejsce w Niemczech w okresie napoleońskim, co nie pozostawało wolne od pewnych słabości5. Jedną $\mathrm{z}$ nich było przesadne przywiązanie do autonomii każdego kraju w regulowaniu własnej przestrzeni, zaś inną - precyzyjna dystynkcja pomiędzy prawem prywatnym i publicznym. Podczas gdy to pierwsze było uznawane za produkt systemowy, odpowiadający na potrzeby ekonomii i społeczeństwa, to drugie - było rozpatrywane jako mniej związane z konkretnym systemem, z uwagi na uwarunkowania polityczne ${ }^{6}$. W tym kontekście powinniśmy odczytywać za „zaskakującą afirmację" - uznanego przez Michaela Stollaisa, autora przełomowej historii prawa w Niemczech ${ }^{7}$ - twierdzenia Savigny’ego, zgodnie z którym, w przeciwieństwie do rzymskiego prawa publicznego, tylko rzymskie prawo prywatne stało się częścią niemieckiego prawa prywatnego ${ }^{8}$. Rzeczywiscie, rzymskie prawo publiczne nie mogło w pełni zostać przetransponowane do germańskich systemów prawnych.

Niezależnie od wewnętrznej racjonalności tego podejścia, bywa ono oceniane z perspektywy jego skrajnych konsekwencji, przypisanych mu wyraźnie przez dwa zdania wiktoriańskiego konstytucjonalisty Diceya. Stwierdził on:

Prawdziwa natura rządów prawa występująca w Anglii zostanie zaprezentowana za pomocą zestawienia $\mathrm{z}$ koncepcją droit administrative..., która przyjmowana jest $\mathrm{w}$ wielu porządkach kontynentalnych ${ }^{9}$.

5 F.C. Savigny, Vom Beruf unserer Zeit für Gesetzgebung und Rechtswissenschaft, Heidelberg 1814.

6 Powiązaną kwestią, której nie da się w tym miejscu wszechstronnie omówić, jest to, czy różnica pomiędzy rzymskim prawem prywatnym a prawem publicznym zależała od tego, czy to ostatnie było mniej systematyczne, jak w przypadku Anglii, na co zwracał uwagę H.E. Yntema, Roman Law and Its Influence on Western Civilization, „Cornell Law Quarterly” 1949, vol. 35, s. 78.

7 F.C. Savigny, System des Heutigen Romisches Recht, Berlin 1840, s. 10, zob. także C. Perelman, Logique juridique, Paris 1976, rozdz. 1.

8 M. Stollais, Geschichte des Offentlichen Rechts in Deutschland, Bd. I, 1600-1800, München 1998, s. 24. Zob. także R. Michaels, Globalizing Savigny? The State in Savigny's Private International Law and the Challenges of Europeanization and Globalization, „Duke Law School Faculty Paper Series" 2005, no. 15, s. 11-12 (wskazując, że dla Savigny'ego prawo publiczne byto „polityczne, a zatem nienaukowe”).

9 A.V. Dicey, Introduction to the Study of the Law of the Constitution (wyd. I, 1885; London 1959, wyd. X; dalej powoływane jako The Law of the Constitution), s. 204. 
Przyznał następnie, że

Na kontynencie, w szczególności we Francji, występuje schemat prawa administracyjnego - znanego Francuzom jako droit administrative - które wywodzi się z koncepcji obcych podstawowym założeniom angielskiego common law, i w szczególności rządów prawa. Ten kontrast widoczny jest w szczególności w ochronie zapewnianej w państwach obcych urzędnikom państwowym ${ }^{10}$.

To właśnie ta koncepcja prawa publicznego legła u podstaw twierdzenia Dicey’a, że angielska konstytucja nie tylko różniła się od kontynentalnych, ale była od nich lepsza, dzięki odwoływaniu się do pojęcia rządów prawa. Stanowisko to jednak było błędne, ponieważ Dicey mylił się co do zakresu władzy administracyjnej funkcjonującej w okresie, gdy pisał pierwsze wydanie swojego traktatu ${ }^{11}$. Co więcej, i co ważniejsze, odwoływał się on do dziewiętnastowiecznego prawa francuskiego, które przecież uległo diametralnym zmianom. Ułomności te nie przeszkodziły wspomnianej koncepcji stać się podstawą wielu późniejszych prac naukowych, wywierając istotny wpływ na ukształtowanie szczególnego rodzaju sposobu myślenia (mentalité) na temat prawa publicznego.

\subsection{Prawo administracyjne jako filar nowożytnego świata}

Interesujące jest to, że sam Dicey, po ujawnieniu antytezy pomiędzy prawem publicznym i prywatnym w porządkach francuskim i angielskim, uplasował ją w szerszej, europejskiej perspektywie, osłabiając tym samym jej znaczenie. Zaobserwował, że do zasady państwa prawa w znaczeniu właściwym dla Anglików bliżej jest prawu administracyjnemu Francji niż prawu administracyjnemu Niemiec $^{12}$. Z tego punktu widzenia, prawo administracyjne nie należy do przesłanek aksjomatu narodowego partykularyzmu. Istnieją względne - $\mathrm{w}$ przeciwieństwie do absolutnych - cechy wspólne i różnice, co czyni omówione porównanie zarówno interesującym, jak i pożytecznym. Funkcjonuje również przekonanie o istnieniu wyższego poziomu wspólnoty w Europie niż w Wielkiej Brytanii.

Tym, kto przesunął analizowany pogląd w kierunku innego ekstremum, był jeden z ulubionych myślicieli Diceya - Tocqueville. W swoim arcydziele przedstawił on tezę o kontynuacji francuskich instytucji administracyjnych, pomimo braku ciągłości politycznej ${ }^{13}$. W późniejszej pracy, opisał francuskie prawo administracyjne jako prototyp $\mathrm{p}^{14}$. Stało się widoczne, że podejście aktualnie brane pod uwagę

10 Ibidem, s. 205.

11 P. Craig, Administrative Law, 5th ed., London 2005, s. 5.

12 A.V. Dicey, The Law of the Constitution..., s. 328, przyp. 3.

13 A. de Tocqueville, L’Ancien régime et la Révolution (1856), według J.P. Mayera, Paris 1967, księga I, część IV.

14 A. de Tocqueville, Rapport fait à l'Académie des sciences morales et politiques sur le livre de M. Macarel, intitulé Cours de droit administratif, [w:] Euvres complètes d'Alexis de Tocqueville. Etudes économiques, politiques et littéraires par Alexis de Tocqueville (Lévy, 1866), s. 63. 
nie było oparte na francuskiej dominacji, ale na prostszym fakcie, że instytucje francuskie były wyrazem wspólnych potrzeb. Pozostałe działania administracji wyrosły jako konsekwencja postępu technicznego (kolei i telegrafu). Uogólniając, w przeciwieństwie do sfery prawa administracyjnego, nowe aktywności państwa nie były systematycznie obejmowane ustawami, lecz determinowane niepisanymi zasadami ogólnymi i paremiami (principes généraux et maximes absolues) ${ }^{15}$. Tocqueville krytykował niektóre z tych zasad, w szczegolności te odnoszące się do odpowiedzialności publicznej i sądowej kontroli, ze względu na ich negatywny wpływ na prawa i wolności jednostek ${ }^{16}$. Jednakże, przewidział on, że takie zasady prędzej czy później będą przestrzegane czy naśladowane przez inne narody europejskie. Jak ostrzegał, nie odbędzie się to za sprawą oryginalności czy dominacji francuskiej tradycji prawnej, ale $z$ tego powodu, że zasady te odpowiadały warunkom funkcjonowania w nowym świecie ${ }^{17}$. Prawo administracyje rozprzestrzeni się zatem gdzie indziej w sposób naturalny.

Być może, najlepszym dowodem przewidywań Tocqueville’a był sławetny traktat Otto Mayera ${ }^{18}$. Wskazał on nie tylko, że zasady prawa administracyjnego we Francji i Niemczech były w znacznej mierze takie same, ale także na przyczynę tego faktu, której upatrywał w zaadaptowaniu bądź naśladowaniu francuskiego prawa administracyjnego w pozostałej części Europy. Skutki tego zjawiska stają się jasne po prześledzeniu historii naszych instytucji administracyjnych.

\section{Zasady ogólne prawa administracyjnego}

Istnieją trzy przyczyny łączenia historii i komparatystyki prawniczej. Po pierwsze, byłoby rzeczą absurdalną, by rozważać aktualny stan prawa administracyjnego bez przemyślenia ewolucji jego zakresu i celów. Jak zauważył Paul Craig, rozumienie wcześniejszego zestawu naszych aktualnych instytucji administracyjnych jest ważne, bo to pozwala nam spojrzeć na nie w sposób dynamiczny ${ }^{19}$. Po drugie, zarówno historia, jak i komparatystyka ujawniają przypadkowość i względność rozwiązań - zasad, instytucji i decyzji - za pomocą których system prawny zwykł mierzyć się

15 Ibidem, s. 66 .

16 Ibidem, s. 68.

17 Ibidem, s. 71 („,notre droit administratif deviendra graduellement celui du monde civilisé, [...] grâce à sa conformité avec la condition des hommes de notre temps").

18 O. Mayer, Deutsches Verwaltungsrecht (1896), przetłumaczone na język francuski przez autora Le droit administratif allemand, Paris 1904. Podobnie zob. M. Fromont, Droit administratif des Pays européens, Paris 2006, s. 11 (utrzymując, że państwa kontynentalne znajdowały się pod głębokim wpływem modelu napoleońskiego).

19 P. Craig, Administrative Law..., s. 47. 
z codziennymi problemami. Po trzecie, i ważniejsze dla naszych celów, rozważanie wagi zarówno wspólnych, jak i rozłącznych cech porządków krajowych wymaga wyczucia ich względnej wagi i zachodzących interakcji. Oczywiście, wiek XX, tak jak XXImógł dostarczyć nowych problemów i nowych rozwiązań. Z tym zastrzeżeniem będą rozpatrywane dwie zmiany systemowe, to jest wpływ orzecznictwa sądowego na ogólne zasady prawa w okresie pomiędzy ostatnią dekadą XIX w. i pierwszą dekadą XX w. i rozprzestrzenienie się zjawiska kodyfikacji postępowania administracyjnego po $1925 \mathrm{r}$. W odniesieniu do pierwszej kwestii zostanie zaprezentowany wynik ostatnich badań komparatystycznych, zaś w przypadku drugiej - uczynię kilka uwag wprowadzających ${ }^{20}$.

\subsection{Określenie zasad ogólnych przez orzecznictwo sądowe}

Porównanie naszych instytucji administracyjnych z instytucjami prawa prywatnego w ramach systemów kontynentalnych ujawnia ostrą różnicę pomiędzy nimi. Kodeksy cywilne szeroko i systemowo uregulowały relacje pomiędzy jednostkami prywatnymi. Napoleon przyjął Code civil des Français w 1804 r. i to on został recypowany w kilku innych państwach. Inna wielka kodyfikacja tej epoki to austriacka z 1811 r. Niektóre państwa traktowały te kodeksy jako źródło inspiracji dla opracowania własych regulacji, włącznie z Holandią (1838), Włochami (1865) i Portugalią (1867). Niemiecki kodeks został uchwalony w 1900 r. i również wywarł znaczący wpływ na inne porządki prawne ${ }^{21}$.

Instytucje administracyjne powstawały natomiast i rozwijały się w sposób nieuporządkowany. Używano ich do rozwiązywania poszczególnych problemów bez żadnego „projektu architektonicznego". Na przykład, nie możemy mówić o linearnym rozwoju francuskiej Rady Stanu, jak dotąd najpotężniejszego sądu w Europie, przeżywającego okresy rozwoju i regresu. Mająca miejsce w 1872 r. fundamentalna zmiana justice retenue $\mathrm{w}$ kierunku justice déléguéee dokonała się dokładnie wówczas, gdy kilka państw niemieckich (Badenia w 1867 r., Prusy w 1872 r.), ale nie wszystkie z nich, zaczęły tworzyć własne sądownictwo administracyjne. W ślad za nimi podążyło Imperium Austro-Węgierskie w 1875 r. i Włochy w 1890 r. Ostatnia kwestia jest szczególnie interesująca, bo pokazuje, po pierwsze, to, że reforma z $1890 \mathrm{r}$.

20 Zob. Administrative Justice: Fin de Siècle, eds. G. della Cananea, S. Mannoni, Oxford University Press, Oxford 2020 [w druku].

21 Na temat debaty, która poprzedzała i następowała po rozprzestrzenieniu się kodeksów cywilnych w państwach dziewiętnastowiecznych, zob. R.C. Van Caenegem, European Law in the Past and the Future, Cambridge 2002. Jak wynika z dalszych rozważań, słowo "zasady” nie jest używane w celu określenia jakiś abstrakcyjnych zasad, lecz fundamentalnych norm porządku prawnego, albo jego części, jako elementów odróżniających zarówno od „polityk”, jak i „regut”. Na ten temat zob. także C. Harlow, Changing the Mindset: the Place of Theory in English Administrative Law, „Oxford Journal of Legal Studies” 1994, vol. 14, s. 419. 
odwróciła wybór dokonany w 1865 r. na korzyść sądowej kontroli wykonywanej przez sądy powszechne i, po drugie, że przez pewien czas niewiele zastanawiano się nad naturą nowej izby, powołanej w ramach włoskiej Rady Stanu ${ }^{22}$. Dopiero na późniejszym etapie kilka czynników, włącznie z prowadzeniem publicznych wysłuchań, podobnych do rozpraw sądowych oraz zdolność do wydawania ostatecznych i wykonalnych rozstrzygnięć, zdeterminowało określenie tej izby jako sądu.

Pomimo tych różnic, przyczyny powstania sądownictwa administracyjnego były w większości podobne. Podczas dyskusji na ten temat podnoszono trzy argumenty, które tu pokrótce wymienię. Pierwszy odnosił się do kontynentalnej koncepcji podziału władzy. W przeciwieństwie do Wielkiej Brytanii, we Francji uważano, że sądy powszechne nie powinny ingerować w sferę władzy wykonawczej ${ }^{23}$. Drugi odnosił się do kwestii wiedzy specjalistycznej, bo w sądach administracyjnych nie zasiadali sędziowie „ogólni”, lecz eksperci z zakresu administracji publicznej. Po trzecie, wskazywano na dwie strony medalu ochrony istotnych interesów. Niektórzy podnosili, że sądy powszechne nie byłyby skłonne do uznawania interesów jednostkowych, różniących się przecież od tych tradycyjnych, wywodzonych z prawa własności i obrotu handlowego. Istniało jednak bardziej upowszechnione przekonanie, że sądy powszechne nie chroniłyby tych materialnie rozumianych interesów, które poddawano ochronie $\mathrm{w}$ drodze nowo wprowadzanych uregulowań, np. w związku z ograniczeniem czy wywłaszczaniem własności prywatnej ze względu na zagrożenia powodzią lub odpowiednio budowaniem kolei.

Wskazane przyczyny różnicowania miały niejednorodną siłę w kontekście instytucjonalnym tamtego okresu. Co jest bardziej znaczące dla naszych celów, sądy administracyjne pracowały nad podstawami niewielu i bardzo lapidarnych przepisów. Raz jeszcze francuskie instytucje były traktowane jako modelowe. Na przykład, podstawy skargi przeciwko aktowi lub środkowi administracyjnemu (les cas d’ouverture du recours), włącznie $\mathrm{z}$ brakiem kompetencji i nadużyciem władzy, były dokładnie podstawami uregulowań przyjętych we Włoszech w 1890 r. Nieporozumieniem byłoby więc, aby zakładać, że istniała jednolitość, nawet gdyby to było intencją prawodawców. Być może najbardziej interesujący i ważny przepis zawarty był w ustawie z 1875 r. ustanawiającej austriacki Trybunał Administracyjny. Przewidywał on dwie podstawy uchylenia środków administracji rządowej, to jest ich niezgodność $\mathrm{z}$ prawem i sprzeczność $\mathrm{z}$ podstawowymi formami postępowania administracyjnego ${ }^{24}$. Pierwsza $\mathrm{z}$ podstaw służyła zapewnieniu poszanowania dla

22 Dla dalszych analiz zob. F.G. Scoca, Administrative Justice in Italy: Origins and Evolution, „Italian Journal of Public Law" 2009, vol. 2, s. 118, dostępne na www.ijpl.eu (dostęp: 14.05.2020).

23 Zob. J.H. Merryman, The French Deviation, „American Journal of Comparative Law” 1996, vol. 44, s. 115; G. Bigot, Ce droit qu'on dit administratif, Paris 2015.

24 Retrospektywnie kwestię tę rozważa A. Ferrari Zumbini, Judicial Review of Administrative Action in the Austro-Hungarian Empire. The Formative Years (1890-1910), „Italian Journal of Public Law" 2018, vol. 10, dostępne na www.ijpl.eu (dostęp: 14.05.2020). W mniej aktualnej literaturze zob. H. Schambeck, The Development of Austrian Administrative Law, „Revue 
decyzji ustawodawcy, stanowiących konsekwencję określonych wybórów politycznych i społecznych, a zatem nadrzędności władzy ustawodawczej nad wykonawczą. $\mathrm{Z}$ kolei druga $\mathrm{z}$ podstaw $\mathrm{w}$ sformułowaniu ,podstawowe formy postępowania administracyjnego" (wesentliche Formen des Administrativverfahrens) wyrażała dwie idee: istnienie dystynkcji pomiędzy prawem materialnym i procedurą, jak również to, że jednostki miały prawo do tego, aby w toku wykonywaniu władzy administracyjnej respektować fundamentalne zasady sprawiedliwości. Oczywiście to, które spośród zasad czy standardów uznać za „podstawowe”, pozostawiono rozstrzygnięciu sądowemu. $Z$ tego powodu orzecznictwo Trybunału nagle zyskało na znaczeniu.

Ujmując rzecz bardziej ogólnie, wszędzie sądy dążyły do samoograniczania interwencji w sferę wykonywania władzy dyskrecjonalnej, w tym znaczeniu że nie uznawały za swoje zadanie zastępowanie orzecznictwa organów władzy wykonawczej. Niezależnie od różnych kontekstów, ta cecha okazała się charakterystyczną dla poszczególnych porządków europejskich i to zarówno tych, w których sądową kontrolę powierzono sądom powszechnym, jak w Wielkiej Brytanii lub Belgii, jak i tych, które utworzyły odrębne sądownictwo administracyjne, czego przykładem są Francja, Austria, Włochy i większość państw niemieckich. Inne uderzające podobieństwa dotyczą sądowej definicji standardów postępowania administracyjnego. Pomimo różnic istniejących pomiędzy anglo-amerykańską koncepcją rządów prawa i niemiecką ideą państwa prawa (Rechsstaat) i jej francuskim oraz włoskim odpowiednikami (État de droit, Stato di diritto) ${ }^{25}$, sądy wykonywaly kontrolę w celu zapobiegania niewłaściwemu wykonywaniu władzy i jej nadużywaniu. Dlatego sądy podejmowały interwencję np. z powodu użycia przez administrację publiczną władzy w celu innym niż dozwolony przez ustawę. Co więcej, w większości ingerowały wówczas, gdy organy administracji podczas wykonywania władzy w celu wskazanym w ustawie czyniły to w sposób uznawany za niewłaściwy, niesprawiedliwy bądź nieracjonalny. Pomimo klarowności tej dystynkcji, rozróżnienie pomiędzy legalnością i sprawiedliwością proceduralną bywało skomplikowane. Odnosząc się do drugiego z tych pojęć, sądy sięgały do ustaleń teorii sprawiedliwości, takich jak naturalna sprawiedliwość w Wielkiej Brytaniii ${ }^{26}$, bądź „natury rzeczy” gdzie indziej, niekiedy nie bez odwołań do teorii prawa naturalnego. Rola sądów przesunęła się zatem $\mathrm{w}$ kierunku zapewniania zasad administracyjnej rzetelności i uczciwości i, jak zaobserwował Vittorio Emanuele Orlando (główny włoski prawnik tamtej epoki), zasady te w większości pokrywały się ${ }^{27}$.

international de sciences administratives" 1962, s. 218 (wskazujący, że Rechstsstaat pojawiło się dopiero po reformie z 1867 r.).

25 Zob. klasyczny kontrast Otto Mayera pomiędzy Polizeistaat i Rechtasstaat: Deutsches Verwaltungsrecht, wyd. III, Bd. I, München 1924, s. 54.

26 Zob. C. McCormick, Judicial Review of Administrative Action in the United Kingdom: the Status of Standards Between 1890 and 1910, „Italian Journal of Public Law” 2018, vol. 10, s. 49, www. ijpl.eu (dostęp: 14.05.2020).

27 V.E. Orlando, Principii di diritto costituzionale, wyd. III, Firenze 1894, s. 27. 


\subsection{Kodyfikacje: rozprzestrzenienie się modelu austriackiego}

O ile w poprzednim punkcie wskazano, że rozkwit prawa administracyjnego zasadniczo nie stanowił, w odróżnieniu od sfery prawa prywatnego, produktu ustawodawstwa, lecz orzecznictwa sądowego, często w związku z poglądami prawników, takich jak Maurice Hauriou czy Otto Mayer, w tym punkcie rozważam przemianę, która charakteryzowała krajobraz prawa od końca pierwszej ćwierci XX w., to jest kodyfikację postępowania administracyjnego. Należy uczciwie na wstępie powiedzieć, że w tym zakresie były podejmowane pewne próby w XIX w., związane głównie z procesem sądowym dotyczącym działań administracji. Niektóre z nich nie zakończyły się sukcesem, czego przykładem jest projekt autorstwa Giandomenico Romagnosi we Włoszech. Inne z kolei udało się zrealizować, np. hiszpańską ustawę z 1899 r., ale żadna z tych inicjatyw nie miała takiego znaczenia, które można porównywać z kodyfikacją austriacką z 1925 r.

Przyczyny przyjęcia pierwszej z kodyfikacji należy rozpatrywać w ujęciu historycznym. Wymaga to podjęcia interdyscyplinarnych studiów, z udziałem prawników, historyków i specjalistów $\mathrm{z}$ innych dziedzin ${ }^{28}$. W tym miejscu poczynić wypada jednak kilka uwag. Istotne jest to, by zdać sobie sprawę z kilku czynników związanych z kodyfikacją.

Po pierwsze, w przeciwieństwie do Sądu Najwyższego Stanów Zjednoczonych, austriacki Trybunał Administracyjny nie mógł unieważnić ustawy. Stosowna zmiana miała miejsce później. Jednakże, jego orzecznictwo zobowiązywało organy administracji publicznej do wysiłku wykonania ustawy i zgodnego z nią korystania władzy dyskrecjonalnej, przy poszanowaniu nie tylko tradycyjnie uznawanych od 1867 r. uprawnień, w tym praw procesowych właściwych dla postępowania administracyjnego. Trybunał poczynił istotne kroki w tym kierunku, uznając $\mathrm{w}$ ten sposób prawo do wysłuchania i obowiązek uzasadnienia.

Po drugie, Trybunał osądzał sprawy indywidualne, początkowo nawet nie cytując swoich orzeczeń, funkcjonując tym samym w mikroperspektywie. Perspektywa makro pojawiła się dopiero w doktrynie, w szczególności dzięki pracom Friedricha Teznera, uwzględniającego problemy o charakterze systemowym i podejmującego próby ich rozwiązania ${ }^{29}$. Bardziej generalny impuls pochodził z wiedeńskiej szkoły prawa, której liderem był Hans Kelsen, a Adolf Merkl - bardziej aktywnym uczniem w dziedzinie prawa administracyjnego. Podczas gdy wcześniejsze teorie prawa koncentrowały się na prawach procesowych $\mathrm{w}$ ramach procedur sądowych, szkoła Kelsena skupiła się na procedurach w związku z wykonywaniem

28 W ramach CoCEAL funkcjonuje odrębna linia badań, koordynowanych przez profesorów Angelę Ferrari Zumbini i Otto Pfersmanna.

29 F. Tezner, Die rechtsbildende Funktion der österreichischen verwaltungsgerichtlichen Rechtsprechung: Die Rechtsquellen d. österreich. Verwaltungsrechtes, Wien 1925. 
innych funkcji i rodzajów władzy ${ }^{30}$. W ten sposób upowszechniła się idea, zgodnie z którą rząd powinien być zdolny do rozpatrywania indywidualnych żądań.

Po trzecie, po upadku Imperium Habsburgów, Republika Austrii poświęciła znaczną uwagę rewizji struktur i procedur rządowych. Po wejściu w życie Konstytucji w 1920 r., wprowadzono inne instrumenty prawne, włącznie z prawem regulującym postępowanie administracyjne, prawem egzekucji administracyjnej i prawem odnoszącym się do sankcji administracyjnych. Przynajmniej dwie cechy pierwszego z tych aktów wymagają zaznaczenia: ramy i zasady ogólne. Ustawodawca działał, kierując się założeniem, że administracja stanowi część władzy wykonawczej, zaś jej zachowania podlegają regulacji na wzór tej, która odnosi się do mechanizmu orzekania. Wynikały z tego pewne konsekwencje, włącznie z używaniem takich terminów, jak „strony” i „interes”, a także możliwość ustanowienia pełnomocnika. Do zasad określonych przez ten akt zaliczyć należy bezstronność, prawo do wysłuchania, prawo do odwołania z powodu niezgodności z prawem materialnym bądź procesowym ${ }^{31}$.

$\mathrm{Z}$ rzadka ustawodawstwo w sferze prawa publicznego przyjmowane było ciepło za granicą lub naśladowane. Tak jednak się stało z austriacką kodyfikacją postępowania administracyjnego. Jedno $\mathrm{z}$ tych niewidzialnych praw, które rządzą postępowaniem narodów, sprawiło, że mimo rozpadu Imperium Habsburgów niektóre włączone doń społeczności podążyły za nowym austriackim ustawodawstwem. Tak uczyniono np. w Czechosłowacji w drodze rozporządzenia rządowego z 13 stycznia 1928 r. i w Polsce - rozporządzeniem Prezydenta RP z 22 marca 1928 r. z mocą ustawy $^{32}$. Jugosławia przyjęła stosowną ustawę dwa lata później, 9 listopada $1930 \mathrm{r}$. Przyczyny leżące u podstaw tych wyborów wymagają szerszych analiz niż te, które są możliwe w ramach niniejszych rozważań. Z prac naukowych i oficjalnych raportów wynika wszakże, że wspólnym celem dokonanych zabiegów była unifikacja interpretacji i stosowania prawa $\mathrm{w}$ nowych, wielonarodowych państwach ${ }^{33}$. Ponadto, co ważniejsze dla tego opracowania, choć unormowania te różniły się pewnymi szczegółowymi rozwiązaniami, zdaniem wielu autorów, zasady ogólne i nawet struktury kodeksów były takie same ${ }^{34}$. Paradoksalnie kodyfikacja austriacka, akcentująca silnie ideały państwa prawa (Rechtsstaat), służyła jako model dla narodów, które porzuciły multinarodowe państwo.

30 Na ten temat zob. G. Isaac, La procedure administrative non contentieuse, Paris 1968, s. 91.

31 Więcej na ten temat zob. R. Herrnritt, La nouvelle procédure administrative autrichienne, „Annuaire Institut International de Droit Public" 1932, s. 251.

32 G. Langrod, Quelques problèmes de la procédure administrative non contentieuse en droit administratif comparé, „Revue international de sciences administratives” 1962, s. 5.

$33 \mathrm{Na}$ ten temat zob. G. Isaac, La procedure administrative..., s. 109.

34 Zob. G. Langrod, Note sur les principes du code de procédure administrative de Tchécoslovaquie, „Revue international de sciences administratives” 1956, s. 199 (dostrzegając podobieństwo); idem, Genèse et lignes directices de la procédure administrative non contentieuse en Pologne, ibidem, 1959, s. 399 (une loi construite à l'instar du modèle autrichien). 
Innego rodzaju paradoksem jest to, że narody te wciąż zachowały kodyfikacje postępowania administracyjnego po zmianie ustrojów prawnych, kiedy dostały się mniej lub bardziej w sowiecką strefę wpływów. W tym samym czasie dokonano kodyfikacji postępowania administracyjnego $\mathrm{w}$ znajdującej się pod reżimem Francisco Franco Hiszpanii, zaś w Norwegii dyskutowano pierwszy projekt takiego aktu. W następnych dziesięcioleciach, nie tylko państwa skandynawskie, ale i zachodnie przyjęły ustawy o postępowaniu administracyjnym. Korzystanie z kodyfikacji przez rozmaite systemy polityczne ujawniło różnorodność celów, włącznie z zabezpieczeniem kontroli politycznej nad biurokracją i zwiększeniem skuteczności działań administracji poprzez wprowadzenie schematu pewnych działań, ograniczenie czasu prowadzenia postępowania i zapewnienie ochrony praw jednostki ${ }^{35}$. Jednakże niektóre zasady ogólne, takie jak zasada legalizmu czy bezstronności, pozostawały w większości takie same. Pytania, które się pojawiły, dotyczyły tego, czy te zasady ogólne oznaczały to samo i czy prowadziły do jednakowego rezultatu. Teraz zwrócimy uwagę na zasady ogólne, spoglądając na zjawisko integracji europejskiej.

\subsection{Zasady ogólne wspólne porządkom narodowym}

Sformułowanie „ogólne zasady prawa” nie stanowi prostego opisu istnienia norm prawnych czy przykazań, które mają ogólny zasięg stosowania i które działają odmiennie od reguł, w tym znaczeniu że nie poddają się aplikacji „wszystko albo nic”, lecz muszą być interpretowane i ważone. W tym należy upatywać sztuki służącej konstruowaniu prawnych uzasadnień i kierowaniu poczynaniami urzędników oraz sędziów. Dobrym przykładem jest przepis austriackiego kodeksu cywilnego z 1811 r., który pozwalał sędziom na sięganie w ostateczności do prawa naturalnego. Włoski porządek prawny dostarcza interesującego przykładu, choć innego rodzaju, bo tu kodeks cywilny pozwala sędziom na odwołanie się do zasad ogólnych krajowego porządku prawnego, a więc ustanawia ograniczenie, które zostało przecież usunięte $\mathrm{z}$ dziedziny prawa administracyjngego przez przepis szczególny, zawierający renvoi do zasad porządku prawnego W spólnoty Europejskiej (obecnie Unii). To tym zasadom musimy poświęcić uwagę. Najpierw zostanie wyjaśniona koncepcja zasad ogólnych w Traktacie Rzymskim, a następnie - orzecznictwo odnoszące się do niektórych spośród tych zasad.

Widzimy, że od końca XIX w. sądy definiowały i redefiniowały niektóre, w większości te same zasady ogólne i, w szczególności, uznawały prawa procesowe jako

$35 \mathrm{Na}$ ten temat zob. także S. Cassese, Legislative Regulation of Adjudicative Procedures: an Introduction, „European Review of Public Law” 1993, s. 15; J. Barnes, El procedimiento administrativo en el derecho comparado, Madrid 1993. Z ostatnich ustaleń komparatystycznych zob. Codification of Administrative Procedure, ed. J.B. Auby, Brussels 2014. 
stosowalne w sprawach pomiędzy jednostkami a organami administracji publicznej. Ale jedną rzeczą jest dostrzec to, że istniały mniej więcej te same zasady ogólne, osobną zaś - autorytatywnie stwierdzić, że występowały zasady ogólne wspólne różnym systemom prawnym. Przed 1945 r. pojęcie „zasady ogólne” w tym ostatnim znaczeniu było używane w dziedzinie prawa międzynarodowego. Sąd Stały był upoważniony do odwoływania się do takich zasad. Podobnie, jego spadkobierca - Międzynarodowy Trybunał Sprawiedliwości - był upoważniony mocą własnego statutu do stosowania nie tylko prawa zwyczajowego oraz traktatów, ale także "zasad ogólnych prawa uznawanych przez narody cywilizowane" ${ }^{36}$. Po procesie norymberskim pojawił się dodatkowy impuls do używania tych zasad ponad granicami narodowymi. Integracja europejska odgrywała kluczową rolę w tym zakresie, ale zaczęła być uwzględniana wraz z podpisaniem Traktatów Rzymskich, na podstawie przepisu odnoszącego się do odpowiedzialności pozaumowanej, co odzwierciedla pozytywistyczny punkt widzenia, który dominował wówczas w tej dziedzinie. Dlatego będziemy najpierw rozważać wybory dokonywane przez Trybunał Sprawiedliwości Unii Europejskiej w początkowych latach swojego orzecznictwa. W dalszej kolejności opiszemy zmiany wywodzące się z Traktatów Rzymskich. W końcu, poddamy analizie dwa orzeczenia Trybunału dotyczące dwóch podstawowych proceduralnych wymagań, to jest prawa do wysłuchania i obowiązku podania uzasadnnienia.

Pomocne może tu być rozpoczęcie rozważań od wyjaśnienia, że TSUE powielał od samego początku niektóre cechy franuskich sądów administracyjnych. Celem wykonywanej przez Trybunał sądowej kontroli było zapobieganie niewłaściwemu korzystaniu z władzy dyskrecjonalnej, z wyłączeniem kompetencji do zastępowania swoim orzeczeniem decyzji podjętych przez organy administracji publicznej, co potwierdzają traktatowo określone podstawy skargi. Zaliczają się do nich: działanie bez umocowania, naruszenie podstawowych wymagań proceduralnych (violation des formes substantielles), nadużycie władzy, naruszenie traktatu albo jakiegokolwiek przepisu wykonującego jego postanowienia ${ }^{37}$. Jednocześnie - jako że rolą TSUE jest zagwarantowanie wykonywania traktatów ${ }^{38}$ - Trybunał nie wahał się stosować ogólnych zasad prawa.

Trybunał używał w tym celu metody komparatystycznej, np. w dobrze znanej sprawie Algera. Krótko rzecz ujmując: kilku pracowników Wspólnego Zgromadzenia Europejskiej Wspólnoty Węgla i Stali (EWWiS) wniosło skargę na decyzję,

36 Artykut 38 (1), c) statutu MTS, na ten temat zob. B. Cheng, General Principles of Law as Applied by International Courts and Tribunals, Cambridge 1987 (rozważając zasady nemo judex in causa propria, audiatur et altera pars, as well as res judicata). W kwestii tego, czy narodowe zasady są rozważane jako normy albo fakty, zob. G. Gaja, Dualism - a Review, [w:] New Perspectives on the Divide between National and International Law, eds. J. Nijman, A. Nollkaemper, Oxford 2007, s. 52.

37 Art. 33 Traktatu o EWWiS; art. 173 Traktatu Rzymskiego.

38 Art. 34 Traktatu o EWWiS, art, 164 Traktatu Rzymskiego. 
mocą której Sekretariat Generalny EWWiS wycofał niektóre, pierwotnie przyznane im korzyści finansowe. Zanim zdecydowano o tym, czy administracja prawidłowo wykonywała swoją kompetencję do odwołania bądź wycofania takich korzyści, TSUE musiał ustalić, czy taka kompetencja w ogóle przysługiwała, ponieważ ani Traktat, ani przepisy szczególne jej wprost nie ustanawiały. Mierząc się z problemem luki systemowej w Traktacie, Trybunał rozwiązał go w sposób genialny. Potwierdził, że ,jeżeli TSUE nie odmawia wymierzenia sprawiedliwości, jest obowiązany do rozwiązania problemu, odwołując się do reguł uznanych przez ustawodawstwo, doktrynę i orzecznictwo państw członkowskich" ${ }^{39}$. W następnej części uzasadnienia TSUE zauważył, że „odwołalność środka administracyjnego dotkniętego wadą prawną jest dopuszczalna we wszystkich państwach członkowskich". Jak Jean Rivero zaznaczył końcowo, droit commun zostało opracowane w Szóstce Europejskiej, w związku z zasadą praworządności na podstawie pogłębionej unifikacji systemów prawnych ${ }^{40}$. Inaczej mówiąc, od początków integracji europejskiej Trybunał sprzeciwiał się pozytywnemu założeniu, że „prawo”, którego poszanowanie miał on gwarantować, pokrywało się z Traktatem i źródłami tworzonymi na jego podstawie. Wypracował natomiast stanowisko, zgodnie z którym istniał już nadający się do wykorzystania wspólny substrat prawny.

Traktat Rzymski nie stanowił w żadnym przypadku odstępstwa od tego założenia. W rzeczy samej, art. 215, odnoszący się do odpowiedzialności pozaumownej instytucji Wspólnoty Europejskiej ${ }^{41}$, implikował nie tylko założenie, że istniały niektóre zasady ogólne prawa wspólne państwom narodowym, ale także używanie metody komparatystycznej ich wyodrębniania. Przepis ten może być więc rozważany bardziej jako potwierdzenie wspólnego dorobku (aquis) niż nowość normatywna. Istnieje poważne ryzyko, że jeżeli zostałoby przyjęte takie minimalistyczne podejście, to nasza zdolność do rozumienia wyłanianiającej się nowej perspektywy

39 Sprawy połączone 7/56, 3/57 to 7/57, „Algera et al. $v$ Common Assembly of the ECSC.

40 J. Rivero, Le problème de l'influence des droits internes sur la Cour de Justice de la Communauté Européenne du Charbon et de l'Acier, „Annuaire français de droit international” 1958, s. 265 („un droit commun qui s'élabore dans l'Europe des Six en matière de contrôle de la légalité, traduction juridique d'une unité plus profonde, qui atteint l'ordre des rapports entre le pouvoir, le droit, et l'homme"). Zob. także E. Stein, Uses, Misuses - and Nonuses of Comparative Law, „Northwestern University Law Review” 1977-1978, vol. 72, s. 206 (wskazując na wzrastającą liczbę legalnych transplantacji dokonywanych na podstawie prawa wspólnotowego), J. Schwarze, Judicial Review of European Administrative Procedure, „Law and Contemporary Problems” 2005, vol. 68, s. 85 (określenie głównych zasad postępowania administracyjnego).

41 Artykuł 215 (2), obecnie zastąpiony przez art. 340 (2) TFUE, który stanowi: „W dziedzinie odpowiedzialności pozaumownej Unia powinna naprawić, zgodnie z zasadami ogólnymi wspólnymi dla praw Państw Członkowskich, szkody wyrządzone przez jej instytucje lub jej pracowników przy wykonywaniu ich funkcji”. Na ten temat zob. także W. van Gerven, The Emergence of a Common European Law in the Area of Tort Liability: the EC Contribution, [w:] Tort Liability of Public Authorities in Comparative Perspective, eds. D. Faigrieve, M. Andenas, J. Bell, Londyn 2002, s. 125. 
byłaby poważnie podważona. W rzeczywistości, interpretacja Trybunału i korzystanie z zasad ogólnych, wspólnych porządkom państw członkowskich wykroczyła poza przepis odnoszący się do odpowiedzialności pozaumownej. U ich podstaw legła klauzula generalna, zgodnie z którą misją Trybunału było zapewnienie po prostu poszanowania prawa $\mathrm{w}$ toku interpretacji i stosowania Traktatu, tak jak odniesienie zawarte $\mathrm{w}$ Traktacie do dostrzegania każdej reguły prawnej (praworządności) ${ }^{42}$. W ten sposób Trybunał zidentyfikował różnorodność zasad uwzględniających wykonywanie władzy przez organy administracji publicznej, włącznie z zasadami pewnością prawa, ochrony uzasadnionych oczekiwań i zasadą proporcjonalności. Inna grupa wspólnych zasad odnosi się do ograniczeń władzy wykonywaniej przez organy administracji publicznej, to jest zasad ucieleśniających prawa fundamentalne, pochodzące z narodowych porządków oraz z Europejskiej Karty Praw Człowieka i Podstawowych Wolności ${ }^{43}$. W ten sposób dodano odwagi sądom krajowym, by te czyniły podobnie w toku kontroli zgodności z prawem krajowych środków i praktyk implementujących prawo Unii Europejskiej.

Dla obecnych celów nie ma potrzeby żeby zajmować się instrumentalnym czy nieinnstrumentalnym wykorzystywaniem praw podstawowych przez Trybuna $1^{44}$. To, co ma znaczenie, to, po pierwsze, fakt, że podejście Trybunału do prawa publicznego podważyło idée recue zestawiania tradycji narodowych $\mathrm{w}$ tej dziedzinie i, po drugie, że to podejście nie tylko ukształtowało ewolucję prawa publicznego we Wspólnocie Europejskiej, ale także wpłynęło na krajowe porządki prawne. Weźmy pod uwagę np. zasadę proporcjonalności. Historycznie jest wątpliwe, czy ta zasada, która zakłada, że przy wykonywaniu władzy nie wolno naruszać praw bardziej niż to jest konieczne dla osiągnięcia celu publicznego, jest tylko niemiecką konstrukcją doktrynalną albo ma pewne elementy wspólne $\mathrm{z}$ angielskimi i kontynentalnymi poglądami na temat racjonalności ${ }^{45}$. Ale nie ma wątpliwości, że test proporcjonalności jest często przeprowadzany przez sądy krajowe, które muszą ustalać wagę przypisywaną interesom indywidualnym, grupowym i publicznym, co nieodłącznie wpływa na równowagę tych interesów.

42 T. Koopmans, The Birth of European Law at the Cross-roads of Legal Traditions, „American Journal of Comparative Law" 1991, s. 495. Fakt, że TSUE nie interpretował po prostu, lecz tworzył prawo, został uznany przez niektórych sędziów, z ostatnich prac na ten temat zob. S. Papasavvas, La creation du droit par le juge de l'Union européenne, „European Review of Public Law" 2012, vol. 24, s. 167.

43 TSUE, sprawa 17/74, Transocean Marine Paint Association v Commission [1974] § 15. Na ten temat zob. także G. della Cananea, Due Process of Law Beyond the State. Requirements of Administrative Procedure, Oxford 2016.

44 Krytycznie na ten temat zob. J.H.H. Weiler, Eurocracy and Distrust: Some Questions Concerning the Role of the European Court of Justice in the Protection of Fundamental Human Rights within the Legal Order of the European Communities, „Washington \& Lee Review” 1986, vol. 61, s. 1103.

45 Zob. A. Stone Sweet \& H. Matthews, Proportionality Balancing and Global Constitutionalism. A Comparative and Global Approach, Oxford 2019. 


\section{Kodyfikacja procedury administracyjnej w Unii Europejskiej}

Jak zostało już powiedziane, wszystkie elementy władzy organów administracji publicznej mają wymiar polityczny w tym sensie, że mogą odzwierciedlać rozmaite preferencje polityczne. Ostatnia część tego rozdziału będzie zasadniczo skoncentrowana na debacie odnoszącej się do kodyfikacji postępowania administracyjnego w Unii Europejskiej. Rozważania zacznę od krótkiej analizy argumentów przemawiających przeciwko kodyfikacji w okresie przed przyjęciem Traktatu z Maastricht i wejściem w życie Traktatu z Lizbony (w 2009 r.). Następnie zostaną przedstawione nowe ramy konstytucyjne leżące u podłoża ostatniego $\mathrm{z}$ tych traktatów. W szczególności zaprezentuję argument, zgodnie z którym w nowej strukturze, art. 298 TFUE ustanawia obowiązek konstytucyjny uregulowania procedury. Uwaga zostanie dalej poświęcona temu, jak taki przepis może zostać implementowany według reguł modelowych ReNUAL, niezależnej pracy naukowców i praktyków. $\mathrm{Te}$ „Reguły Modelowe” są oparte na założeniach aktualnego porządku prawnego, w celu usystematyzowania, uzupełnienia i sformułowania nowoczesnych propozycji w zakresie, w którym nie ma jasnych reguł ochrony obywateli i biznesu ${ }^{46}$.

\subsection{Debata o kodyfikacji: od Maastricht do Lizbony}

Po przyjęciu Jednolitego Aktu Europejskiego w 1984 r. i środków umożliwiających stworzenie wspólnego rynku zarówno politycy jak i przedstawiciele doktryny zaczęli zwracać uwagę na potrzebę kodyfikacji unijnego postępowania administracyjnego, odnoszącego się do stosowania prawa i tworzenia przepisów administracyjnych (rule-making). Argumenty podnoszone na rzecz kodyfikacji spotkały się z krytyką opartą na różnych podstawach ${ }^{47}$. Trzy z nich zostaną tutaj omówione. Pierwszy dotyczył potrzeby lepszych ram prawnych w celu ochrony jednostek i ich grup, drugi odnosił się do tego, że o ile treść aktów prawa unijnego znajdowała się pod dyskretnym wpływem lobbystów, to obywatele nie mieli w tym niemal żadnego udzialu. Trzeci zaś argument dotyczył potrzeby „ustawowej” kodyfikacji,

46 Zob. ReNEUAL Model Rules on EU Administrative Procedure, eds. P. Craig, H. Hofmann, J.P. Schneider, J. Ziller, Oxford 2017. Dzieło to zostało opublikowane w kilku językach, zob. strona internetowa ReNEAULS: www.reneual.eu (dostęp: 14.05.2020).

47 Na temat kodyfikacji zob. G. della Cananea, From Judges to Legislators? The Codification of EC Administrative procedures in the Field of State Aid, „Rivista italiana di diritto pubblico comunitario" 1995, s. 967. Zob też pogląd przeciwny, C. Harlow, Codification of EC Administrative Procedures? Fitting the Foot to the Shoe or the Shoe to the Feet?, „European Law Review” 1996, vol. 2, s. 331. 
w miejsce pozostawienia pola dla kreowania norm orzeczniczych w drodze wykładni sądowej.

Pierwszy z tych argumentów łączył w sobie ogólne uzasadnienie dla kodyfikacji postępowania administracyjnego i bardziej szczegółowych procedur funkcjonujących we Wspólnocie Europejskiej. Generalnie, kodeksy, bez względu na ich treść, są bardzo użytecznym środkiem ograniczającym i porządkującym władzę dyskrecjonalną, zapobiegającym arbitralności. Po przyjęciu regulacji prawnej tok postępowania administracyjnego może zostać zweryfikowany $\mathrm{z}$ wprowadzonymi standardami. W związku z tym wykonywanie przypisanej administracji władzy dyskrecjonalnej stanowić może przedmiot kontroli organów pochodzących z wyboru oraz sądów. Jednakże, jak często podnosi się w doktrynie francuskiej, wspomniane reguły kodeksowe mogą być nazbyt sztywne, upodabniając się do gorsetu usztywniającego (corset paralysant) ${ }^{48}$. Tym argumentem posługiwała się bardzo często Komisja w celu usprawiedliwienia istniejącego stanu rzeczy.

Drugi argument koncentruje się na fakcie, że w odróżnieniu od prawa do wysłuchania, partycypacja społeczna nie należy do zasad ogólnych uznawanych i chronionych przez TSUE. Bardziej ogólnie rzecz ujmując, o ile sądy są skłonne udzielać ochrony prawom jednostki, zdają się pomijać interesy kolektywne. Na przykład, publiczny kontekst działań administracyjnych jest traktowany instrumentalnie i tylko pośrednio, w granicach niezbędnych do sprawowania sądowej kontrolii ${ }^{49}$. Jedynie wprost unormowane obowiązki konsultacji lub prawdziwej partycypacji zyskują bardziej akceptowalny poziom ochrony. Ten argument ma dalsze uzasadnienie $\mathrm{w}$ zakresie, $\mathrm{w}$ jakim prowadzi do prymatu idealnego modelu postępowania typu „zawiadom i daj możliwość wypowiedzenia się" nad tym, który opiera się na pardygmacie procesu sądowego.

Wreszcie, bez względu na to, czy preferowany byłby bardziej lub mniej indywidualnie zorientowany typ regulacji postępowania administracyjnego rodzi się pytanie o to, czy może zostać on zapewniony przez legislatywę bądź orzecznictwo sądowe. Wielu obserwatorów w różnych okresach i ramach instytucjonalnych już zauważyło, że sądowa kontrola była i wciąż jest wewnętrznie ograniczona. Nadchodzi późno, jest niestabilna i kosztowna zarówno dla jednostek, które zamierzają zaskarżyć akt administracyjny, jak i dla społeczeństwa jako całości, które czerpało korzyści z partycypacji generalnej ${ }^{50}$. Zwolennicy prawa sędziowskiego odpowiadali, że sądy mogą zapewnić bardziej elastyczne rozstrzygnięcie, bez zbędnej uniformizacji, która jest nieodłączną konsekwencją regulacji ustawowej.

Argument przeciwny, dotyczący elastyczności postępowania, determinuje uzasadnioną przewagę regulacji ramowej, ograniczonej do szeroko ujętych zasad, z pozostawieniem pewnego marginesu swobody dla sądów. Na przykład analiza

48 G. Isaac, La procedure administrative...

49 Ibidem, s. 72.

50 S. Cassese, Legislative Regulation..., s. 17. 
włoskiej ustawy o postępowaniu administracyjnym przekonuje, że były one gotowe używać pewnych klauzul prawnych, w szczególności odnoszących się do due process i dostępu do informacji. To pokazuje, że wymagana jest bardziej szczegółowa ocena istniejącego stanu prawnego, zanim podejmiemy próbę wyciągnięcia odpowiednich wniosków, niezależnie od zastrzeżenia poczynionego przez Hume’a co do przekształcenia pomysłu kodyfikacji w powinność.

Inny kontrargument wynika z natury Wspólnoty Europejskiej. Chociaż zasadniczo można się zgodzić z tym, że interwencja parlamentów zwiększa legitymację demokratyczną, to w przypadku Wspólnoty Europejskiej tak nie było, ponieważ władza ustawodawcza była dzielona pomiędzy Parlament Europejski i Radę Ministrów. Byłoby jednakże błędem oceniać Unię na podstawie standardów wypracowanych w ramach narodowych systemów politycznych.

W tym miejscu należy podkreślić wieloaspektowość prowadzonej debaty. Działania administracyjne stawały się coraz bardziej zróżnicowane i kompleksowe niż miało to miejsce przez dziesiątki lat. Prawa procesowe przeniknęły do różnych obszarów, ale nie do wszystkich. Sądy zmuszone były zmagać się z nowymi wyzwaniami, jak np. ustawodawstwo ukierunkowane na ochronę interesów kolektywnych takich jak czystość środowiska ${ }^{51}$. Sukces argumentów podnoszonych na rzecz kodyfikacji nie mógł zależeć tylko od ich wewnętrznej spójności. To organy polityczne miały zmierzyć się z nowymi i dawnymi zagadnieniami oraz zdecydować, czy takie ustawodawstwo jest potrzebne, a jeżeli tak - czy powinno być skonstruowane za pomocą pojemnych, charakteryzujących się otwartą tekstowością pojęć, czy też - w drodze regulacji szczegółowej.

\subsection{Po Lizbonie: obowiązek konstytucyjny uregulowania postępowania administracyjnego}

Opisana wyżej sytuacja zmieniła się po 2009 r., w nowych warunkach konstytucyjnych Unii Europejskiej ${ }^{52}$. Ramy artykułu nie pozwalają na szczegółową analizę towarzyszących temu uwarunkowań, to jest ewolucji unijnego porządku konstytucyjnego. Wystarczy wskazać, że Traktat Lizboński wprowadził trzy szczególnie istotne zmiany z punktu widzenia teorii systemów prawnych i, dodatkowo, ustanowił nowy konstytucyjny imperatyw do uregulowania postępowania przed organami administracji unijnej.

51 Na temat niechęci TSUE do udzielenia ochrony tym interesom zob. C. Harlow, Towards a Theory of Access for the European Court of Justice, „Yearbook of European Law” 1992, vol. 12, s. 213.

52 Na temat władzy wykonawczej przed 2009 r. zob. D. Curtin, Executive Power of the European Union. Law, Practices, and the Living Constitution, Oxford 2009. Na temat nowego porządku po Traktacie z Lizbony zob. P. Craig, The Lisbon Treaty: Law, Politics, and Treaty Reform, Oxford 2013 (wyd. popr.). 
Trzy prawnie znaczące zmiany, które są istotne z perspektywy teorii systemów prawnych, odnoszą się do unijnego aspektu społecznego, jego organizacji i kompetencji prawotwórczych ${ }^{53}$. Pierwszy to taki, że Traktat z Lizbony odzwierciedlał bardziej zróżnicowane członkostwo niż wcześniej, bo nastąpiła akcesja nowych państw, spośród których wiele zmieniło systemy polityczne po upadku muru berlińskiego. To także wzmocniło demokratyczny wymiar Unii, dzięki przepisom odnoszącym się do demokracji partycypacyjnej. Last but not the least, w przeciwieństwie do poprzednich traktatow, Traktat Lizboński przydał nowy status Karcie Praw Podstawowych Unii Europejskiej przyjętej w Nicei w 2000 r. Artykuł 6 ust. 1 TUE przyznaje Karcie taką samą wartość prawną jak traktatom i, co istotne, uczyniono to w kontekście przepisu, który określa znaczenie zarówno Europejskiej konwencji praw człowieka i podstawowych wolności, jak i wspólnych tradycji konstytucyjnych jako źródeł praw jednostki ${ }^{54}$. Po drugie, to właśnie dlatego, że Unia Europejska jest unią zarówno państw, jak i narodów, aspekt społeczny jest brany pod uwagę jako czynnik większości procesów decyzyjnych ${ }^{55}$. Co więcej, administracja europejska, raz scentralizowana w Komisji, teraz jest określana przez mnogość agencji ${ }^{56}$. Po trzecie, prawotwórcze kompetencje Unii Europejskiej zostały lepiej zdefiniowane, z podziałem na akty o charakterze ustawowym, akty delegowane i akty wykonawcze (art. 290 ust. 1 TFUE), które - analizowane w całości - mają niższą range niż przepisy traktatowe, ogólne zasady prawa i inne uzgodnienia.

Mając powyższe na uwadze, staje się jasne, że systemowa wykładnia traktatów opartych na demokracji i prawach podstawowych jest możliwa. Można podnosić, że powinniśmy wspierać prawa podstawowe, w tym sensie, że bez adekwatnej konstrukcji sprawiedliwości proceduralnej prawa te stałyby się częścią „prawa w książkach” w przeciwieństwie do prawa w działaniu. „Reguły Modelowe” opracowane przez ReNUAL rozwijają ten argument przez uogólnienie niektórych istniejących instytucji i propozycję nowych zarówno dla decyzji, jak i umów ${ }^{57}$. Można alternatywnie podnieść, że jeżeli Unia Europejska ma być demokracją partycypacyjną, nie może to dotyczyć jedynie jej instytucji politycznych, ale

53 Dzieło Santi Romano, L’ordinamento giuridico (1946, II wyd.) zostało w końcu przetłumaczone na angielski, zob. The Legal Order, London 2017.

54 Na temat początkowo prezentowanych poglądów na temat Karty zob. A. von Bogdandy, The European Union as a Human Right Organization? Human Rights and the Core of the European Union, „Common Market Law Review” 2000, vol. 37, s. 1307.

55 W. Van Gerwen, The European Union: A Polity of States and Peoples, Stanford 2005.

56 Z ostatnich analiz agencji unijnych zob. EU Executive Governance: Agencies and Procedures, eds. M. Conticelli, M. De Bellis, G. della Cananea, Torino 2019.

57 Weźmy np. pod uwagę MR III-25 (2) o konsultacji ze społeczeństwem, zgodnie z którą „organ administracji publicznej może wybrać konsultację przez wysłuchanie publiczne. Musi zostać ono ogłoszone publicznie, poprzez obwieszczenie na oficjalnej stronie internetowej... Wysłuchanie publiczne musi być przeprowadzone w stosownym czasie przed podjęciem decyzji”. 
także jej administracji. W tym znaczeniu, „Reguły Modelowe” wykraczają poza istniejące przepisy prawa, wyznaczając ogólny obowiązek konsultacji posiadaczy interesów, na które wpływ wywierać mogą różnorodne przepisy administracyjne. Z obowiązkiem tym spójne pozostaje wymaganie „Reguł Modelowych”, by każdy organ wydający przepisy administracyjne dostarczał niezbędnej informacji podmiotom biorącym udział w konsultacjach, żeby umożliwić im wyrażenie własnych spostrzeżeń i wniosków ${ }^{58}$. Wskazane rozumowanie pozostaje w sposób niezaprzeczalny związane z wartościami unijnymi, o których mowa w art. 4 TUE. Zalety tego toku myślenia mogą jednakże być podważone, podobnie jak stopień ich zgodności ze sposobem zarządzania grupami społecznymi tworzącymi Unię Europejską.

To tłumaczy przyczyny koncentrowania się na aspekcie bardziej szczegłowym, a wynikającym z art. 298 TFUE, który dotyczy administracji unijnej. W przeciwieństwie do większości przepisów traktatowych, art. 298 został wprowdzony przez Traktat Lizboński ${ }^{59}$. Jego innowacyjny charakter wynika z odwoływania się po raz pierwszy do administracji unijnej jako całości. Pomimo, że taki przepis nie przykuł od razu uwagi komentatorów, okazuje się bardzo istotny ${ }^{60}$. Składa się z dwóch jednostek redakcyjnych, pierwsza określa zasady rządzące europejską administracją, zaś drugi indywidualizuje środki implementujące te zasady i zapewniające ich efektywność. Dla osiągnięcia celów Unii Europejskiej, jej instytucje korzystają z administracji unijnej, która musi być niezależna, skuteczna i otwarta. Mechanizmy zabezpieczające zgodność działań administracji unijnej z tymi wartościami należą zasadniczo do normatywnych, mimo że można zaobserwować konieczność ponownego rozważenia pewnych praktyk czy szerzej - kultury administracji unijnej. Zaznaczając to, art. 298 ust. 2 akcentuje pierwszeństwo odpowiedzialności Komisji i Parlamentu, które razem tworzą dualną legislatywę Unii Europejskiej. Powierzono im kompetencję prawotwórczą, choć w niewielkim stopniu określono sposób, w jaki mają to czynić, a zwłaszcza zakres treściowy.

Trzy uwagi wydają sie zasadne na tym etapie rozważań. Pierwsza, o charakterze normatwnym, odnosi się do szerokiego zakresu stosowania art. 298 i wizji administracji unijnej, którą on wytycza. Przepis traktatu nie odnosi się tylko do instytucji

58 Zwróćmy uwagę na MR II-4 (3-4) o konsultacjach i partycypacji, zgodnie z którymi organ administracji unijnej musi zaprosić każdego, kogo mogą dotyczyć nowe reguły, do poczynienia uwag i takie „uwagi są czynione publiczne w sposób pozwalający na publiczną wymianę poglądów".

59 Art. 298 TFUE stanowi: „1. Wykonując swoje zadania, instytucje, organy i jednostki organizacyjne Unii korzystają ze wsparcia otwartej, efektywnej i niezależnej administracji europejskiej. 2. Z poszanowaniem regulaminu i warunków przyjętych na podstawie art. 336, Parlament Europejski i Rada, stanowiąc w drodze rozporządzeń zgodnie ze zwykłą procedurą ustawodawczą, określają stosowne przepisy".

60 Zob. P. Craig, A General Law on Administrative Procedure, Legislative Competence and Judicial Competence, „European Public Law” 2013, vol. 19, s. 503. 
i organów Unii, których jednostki pełnią - z wyjątkiem Komisji - rolę sekretariatu, bez zewnętrznego władztwa wobec innych podmiotów publicznych czy jednostek. Odwołuje się bowiem po raz pierwszy w Traktacie do agencji unijnych.

Druga uwaga jest natury celowościowej, bo odwołuje się do materialnych celów, które art. 298 ma realizować. Niezależnie od tego, czy wybór postawienia otwartości na pierwszym miejscu, a za nią efektywności i niezależności wskazuje na priorytet, o ile nie na hierarchię tych zasad, ostatnia z nich stanowi powtórzenie wymagania niezależności ustanowionej od czasów Traktatu Paryskiego i Rzymskiego. Natomiast zarówno otwartość, jak i efektywność mają bardziej innowacyjny charakter. Interesującą, wymagającą odrębnego rozważenia kwestią jest to, czy autorzy projektu Traktatu byli świadomi wzrastającego niezadowolenia z działania Unii Europejskiej.

Trzecia uwaga odnosi się do konsekwencji wynikających z art. 298 TFUE, rozważanych jako całość. Przepis ten nie tylko wprost upoważnia Parlament Europejski i Komisję do stanowienia prawa. Jego język jest kategoryczny („ma stanowić przepisy") i buduje jasną relację pomiędzy celami i środkami ${ }^{61}$. W związku z tym, aby Parlament i Komisja mogły stanowić prawo, Komisja musi składać wnioski „W tym celu”, by wypełnić dyspozycję art. 298 ust. 2. Niezależnie od rezolucji podejmowanych przez Parlament na podstawie art. 225 TFUE, Komisja powstrzymywała się od tego, wskazując, że nie było to konieczne ${ }^{62}$. Można tu mówić o czysto politycznej decyzji. Bez względu na to, czy była ona politycznie uzasadniona, Parlament upoważniony był do przeprowadzenia stosownej oceny, tak jak jest do tego umocowany Parlament, którego kadencja rozpoczęła się w 2019 r.

\subsection{Trzy ścieżki „Reguł Modelowych”}

Bez względu na zaniechanie Komisji przygotowania wniosku, regulacja czy zestaw regulacji na podstawie art. 298 pozostaje optymalnym sposobem unormowania postępowania administracyjnego w Unii Europejskiej niezależnie od tego, czy opiera się na „Regułach Modelowych”, czy też nie. Rozważone zostają jeszcze dwie inne możliwości ma poziomie Unii Europejskiej, ale przez sądy, a także na poziomie narodowym - przez ustawodawstwo albo wytyczne rządowe.

Zalety unormowania mającego podstawę $\mathrm{w}$ art. 298 TFUE mogą być oceniane na trzech poziomach: aksjologicznym, instytucjonalnym i operacyjnym. W ramach pierwszego z nich, "Reguły Modelowe” dążą do „opracowania najlepszego sposobu przełożenia wartości konstytucyjnych Unii mogą na reguły postępowania

61 Na ten temat zob. także J. Ziller, Is a a Law of Administrative Procedure for the European Union Necessary?, „Rivista italiana di diritto pubblico comunitario” 2011, s. 699.

62 Zob. także odpowiedź udzieloną Komisji przez Wiceprzewodniczącego Dombrovskisa na pytanie Parlamentu dotyczące prawa o postępowaniu administracyjnym Unii Europejskiej. 
administracyjnego obejmujące pozaustawową implementację prawa i polityk unijnych"63. Mogą więc sprzyjać zgodności z ogólnymi zasadami prawa unijnego, zwięźle ujętymi w preambule. Należy zwrócić tu uwagę na dwa aspekty. Po pierwsze, obowiązek konsultacji ma szerokie reperkusje, bo pozwala podmiotom spoza machiny rządowej odgrywać pewną rolę w kształtowaniu polityki, która jest coraz ważniejsza na poziomie unijnym, skoro $\mathrm{w}$ wielu dziedzinach istotne decyzje polityczne są podejmowane przez instytucje i agencje unijne. Po drugie, $z$ uwagi na zwiększający się zakres zadań realizowanych przez urzędników unijnych i krajowych istnieje konieczność racjonalizowania biurokracji, w świetle postulatu dobrej administracji. Pod względem instytucjonalnym, jak już wyjaśniłem, istnieje precyzyjnie skonstruowany obowiązek uregulowania czynności administracji unijnej oraz korespondujący z nim obowiązek organów administracji unijnej i agencji do przestrzegania wytycznych formułowanych przez unijne instytucje polityczne. Pod względem operacyjnym, „Reguły Modelowe” mogłyby funkcjonować jako „płyta główna”, uzupełniana przez szczególne przepisy sektorowe w rozmaitych obszarach. $Z$ jednej strony, niezbędny poziom elastyczności byłby zapewniany przez relację lex generalis - lex specialis, a z drugiej - szczególne normy sektorowe mogłyby być interpretowane w korelacji z zasadami ogólnymi ${ }^{64}$.

Przy braku ustawodawstwa implementującego obowiązek ustanowiony w art. 298 TFUE, możemy się zastanawiać nad tym, czy sądy unijne mogą korzystać z „Reguł Modelowych”. Wielu komentatorów podnosiło, że - z zastrzeżeniem pewnych wyjątkowych przepisów traktatowych - zasady unijnego prawa administracyjnego zostały rozwinięte w orzecznictwie sądowym, w szczególności TSUE. Podążając za tym rozumowaniem, to sądy musiałyby rozważyć, czy „Reguły Modelowe” mogłyby być pomocne wówczas, gdy sądy wskazują na zasady procesowe i zasady materialnoprawne, które mają być przestrzegane przez organy administracji. Naruszające ogólne zasady prawa działanie agencji byłoby zatem bezprawne. Nie ma w tym więc nic dziwnego, że zestaw reguł, wywiedzionych z zasad ogólnych unijnego prawa administracyjnego, ma być stosowany wówczas, gdy jedna $\mathrm{z}$ tych zasad jest powoływana przed sądem unijnym. To jest $\mathrm{w}$ rzeczy samej pewien paradygmat, gdy rzecznicy generalni cytują orzecznictwo innych sądów bądź prace eksperckie, jak miało to miejsce w opini doręczonej przez AG Campos Sanchez-Bordona w ostatnio prowadzonej sprawie, a dotyczącej unijnej procedury mieszanej, to jest takiej, w której udział biorą organy administracji unijnej i krajowej ${ }^{65}$.

Oczywiście, jeden skowronek wiosny nie czyni, ale AG Kokott również powołała się na „Reguły Modelowe” w innym kontekście, to jest w zakresie umów zawieranych przez administrację unijną. Na początek należy powiedzieć, że sąd niższej

63 ReNEAUL's Model Rules, Księga I, § 14.

64 Zob. ReNEAUL's Model Rules, Księga I-2 (2).

65 Opinia AG Campos Sanchez-Bordona doręczona 27 czerwca 2018 r., w sprawie C-219/17, Berlusconi v. IVASS, przyp. 21. 
instancji, skonfrontowany z twierdzeniem skarżącego, że unijna administracja nie mogła jednostronnie odzyskać zobowiązania kontraktowego, nie zakwestionował podstaw żądania skarżącego, opartego na zasadach ogólnych kontraktowania, lecz wyjaśnił, że administracji może przysługiwać kwestionowane prawo na podstawie przepisów szczególnych ${ }^{66}$. Innymi słowy, nie kontestując lex generalis, Trybunał oparł swoje rozstrzygnięcie na lex specialis. W swoim stanowisku na etapie postępowania odwoławczego AG Kokott sformułowała inny pogląd, argumentując, że państwa członkowskie przyjmują różne koncepcje wykonywania władzy przez organy administracji publicznej i, w związku z tym, wypowiedzenia umowy ${ }^{67}$. W konsekwencji, jak podniosła, „kompetencja Komisji do przyjęcia decyzji wykonawczych w celu odzyskania długów kontraktowych nie może być też kwestionowana przez odwołanie się do zasad ogólnych prawa kontraktowego". Powodem jest to, co liczy się bardziej dla celów tego opracowania, że „takich zasad po prostu w ogóle nie stosuje się do umów z organami administracji publicznej”"68. W tym kontekście wyłania się inna zasada, pozwalająca administracji na działanie jednostronne. Czas pokaże, czy TSUE podąży za koncpecją przyjętą w sprawie AG, czy też sformułuje inne odniesienia do „Reguł Modelowych”.

Założenia innego rozumowania wykorzystującego porządki krajowe są następujące. „Reguły Modelowe” składają się z zasad i reguł stosowanych przy podejmowaniu wyrażanego $\mathrm{w}$ różnych formach działania instytucji, ciał i agencji unijnej. Postępowanie organów krajowych jest uregulowane przez przepisy porządków tych krajów członkowskich, nie zaś przez „Reguły Modelowe”, do których wszakże prawo krajowe może się odwoływać. Organy krajowe muszą bowiem stosować ogólne zasady prawa, jeżeli działają w sferze prawa unijnego, ale nie ma przeszkód do szerszego ich wykorzystywania. Mają np. taką możliwość w celu usuwania ryzyka nierównego traktowania, które mogłoby się ziścić wówczas, gdyby w ramach katalogu podobnych przypadków jedne miały być rozstrzygane na podstawie prawa krajowego, inne zaś - unijnego. Mogą tak również uczynić z tego powodu, że prawo unijne jest uznawane za bardziej korzystne niż krajowe. Państwo członkowskie może też inspirować się „Regułami Modelowymi” albo formalnie odwoływać się do nich, dokonując reform własnych reguł procesowych bądź ustanawiając nowe ${ }^{69}$. Reguły te mogą także być wykorzystywane w ramach kolektywnego działania państw członkowskich, które mogą tak zdecydować z przyczyn

66 Sąd Pierwszej Instancji, sprawa T-644/14, ADR Center v. European Commission, § 200.

67 Opinia AG Kokott doręczona 7 listopada 2019, sprawa C-584/17 P, ADR Center v. European Commission, § 82.

68 Opinia AG Kokott doręczona 7 listopada 2019 r., sprawa C-584/17 P, ADR Center v. European Commission, § 84 (odniesienie do „Reguł Modelowych” znajduje się w przyp. 65).

69 Rozwinąłem tę argumentację gdzie indziej, zob. G. della Cananea, A Law on EU Administrative Procedures: Implications for National Legal Orders, [w:] Current Issues of the National and EU Administrative Procedures (the RENEUAL Model Rules), eds. G. Balazs, L. Berkès, A. Varga, Budapest 2015, s. 283. 
instrumentalnych bądź pozainstrumentalnych, np. w ramach pogłębionej współpracy. Nie ma przeszkód, aby współdziałające państwa posługiwały się „Regułami Modelowymi" w celu udoskonalenia procesu stanowienia prawa i wykonywania władzy dyskrecjonalnej zgodnie z uznanymi przez Kartę Praw Podstawowych Unii Europejskiej prawami fundamentalnymi i w celu przeciwdziałania niesprawiedliwemu różnicowaniu jednostek. Z kolei z perspektywy instrumentalnej, „Reguły Modelowe” mogą służyć ulepszeniu współpracy przy realizacji zadań stanowiących przedmiot wspólnego zainteresowania. W tym zakresie korzystać można odpowiednio ze standardów opisanych w Księdze V i VI, odnoszących się do wzajemnego wsparcia i wymiany informacji.

Podsumowując, postawiona hipoteza nie powinna być rozważana jako potwierdzająca trafność wcześniejszych uwag, to jest, że regulacja art. 298 TFUE jest najlepszą opcją do osiągania celów otwartej administracji i transparentności. Jednakże powinniśmy pamiętać o trudnościach w przyjęciu takiej regulacji w Unii Europejskiej 27 państw o różnych tradycjach administracji. To jest jednak tylko jeden aspekt szerszego zagadnienia. Właśnie dlatego, że Unia Europejska była coraz bardziej zróżnicowana, przepisy o pogłębionej współpracy zostały włączone do Traktatu z Nicei i, tym bardziej po kolejnym rozszerzeniu Unii, przepisy te zostały zmienione przez Traktat Lizboński ${ }^{70}$. Należy przyjąć, że każde podejście będzie wymagało dokonania wyboru co do tego katalogu praw fundamentalnych albo podstawowych standardów współpracy administracyjnej. Opowiedzenie się za określonym ich zbiorem będzie odzwierciedlało założenia lub dobór tych praw w poszczególnych społeczeństwach bądź też znaczenie, jakie należy przypisywać pewnym standardom dobrej administracji. Nie obędzie się to bez konsekwencji dla pozostałych partnerów, jest to nieuniknione. Na tym opiera się logika pogłębionej współpracy. Czy ta logika przeważy, to inne pytanie, które wymaga odrębnego potraktowania.

(tłum. Joanna Wegner)

Giacinto della Cananea, profesor zwyczajny prawa administracyjnego na Uniwersytecie w Bocconi (Mediolan). W 2016 r. uzyskał od Europejskiej Rady ds. Badań Naukowych grant na badania komparatystyczne dotyczące Wspólnego rdzenia europejskiego prawa administracyjnego (CoCEAL). W 2018 r. otrzymał, w imieniu ReNEUAL, pierwszą nagrodę Spinelli za prace nad kodyfikacją procedur administracyjnych w Unii Europejskiej. Jego ostatnia monografia nosi tytuł Due Process of Law Beyond the State (Oxford University Press 2017), zaś ostatnie opracowanie podręcznikowe, którego był redaktorem, to Handbook of European Administrative Law (współautorzy: Carol Harlow i Paivi Leino; Hart 2017). Od 2009 r. jest współredaktorem „Italian Journal of Public Law”.

70 Na ten temat zob. także ostatni rozdział pracy P. Craiga, The Lisbon Treaty... 
